\title{
De neurologie van het urogenitaalstelsel : een klinisch-neurofysiologisch en urologisch onderzoek bij patienten met diabetes mellitus
}

Citation for published version (APA):

Anten, H. W. M. (1989). De neurologie van het urogenitaalstelsel : een klinisch-neurofysiologisch en urologisch onderzoek bij patienten met diabetes mellitus. [Doctoral Thesis, Maastricht University]. Rijksuniversiteit Limburg. https://doi.org/10.26481/dis.19890526ha

Document status and date:

Published: 01/01/1989

DOI:

10.26481/dis.19890526ha

Document Version:

Publisher's PDF, also known as Version of record

Please check the document version of this publication:

- A submitted manuscript is the version of the article upon submission and before peer-review. There can be important differences between the submitted version and the official published version of record.

People interested in the research are advised to contact the author for the final version of the publication, or visit the DOI to the publisher's website.

- The final author version and the galley proof are versions of the publication after peer review.

- The final published version features the final layout of the paper including the volume, issue and page numbers.

Link to publication

\footnotetext{
General rights rights.

- You may freely distribute the URL identifying the publication in the public portal. please follow below link for the End User Agreement:

www.umlib.nl/taverne-license

Take down policy

If you believe that this document breaches copyright please contact us at:

repository@maastrichtuniversity.nl

providing details and we will investigate your claim.
}

Copyright and moral rights for the publications made accessible in the public portal are retained by the authors and/or other copyright owners and it is a condition of accessing publications that users recognise and abide by the legal requirements associated with these

- Users may download and print one copy of any publication from the public portal for the purpose of private study or research.

- You may not further distribute the material or use it for any profit-making activity or commercial gain

If the publication is distributed under the terms of Article 25fa of the Dutch Copyright Act, indicated by the "Taverne" license above, 


\section{DE NEUROLOGIE VAN HET UROGENITAALSTELSEL}

Een klinisch-neurofysiologisch en urologisch onderzoek

bij patiënten met diabetes mellitus. 
" 


\section{PROEFSCHRIFT}

ter verkrijging van de graad van doctor

aan de Rijksuniversiteit Limburg te Maastricht, op gezag van de Rector Magnificus, Prof. Dr. F.I.M. Bonke, volgens het besluit van het College van Dekanen, in het openbaar te verdedigen op vrijdag, 26 mei 1989

om 16.00 uur

door

HUBERTUS WILHELMUS MARIE ANTEN

geboren te Heerlen in 1943.

1989 
PROMOTORES:

Prof. Dr. P.I.M. van der Lugt

Prof. Dr. F. Spaans

BEOORDELINGSCOMMISSIE:

Prof. Dr. J. Drukker (voorzitter)

Prof. Dr. M.A. Allessie

Prof. Dr. R.A. Janknegt

Prof. Dr. P.G. Knipschild

Prof. Dr. S.L.H. Notermans 


\section{WOORD VOORAF}

Het in dit proefschrift beschreven onderzoek vond plaats op de afdeling klinische-neurofysiologie en afdeling neurologie van het Maaslandziekenhuis te Sittard en Geleen.

Allen, die bij het tot stand komen van dit proefschrift behulpzaam zijn geweest, ben ik zeer erkentelijk. Speciaal wil ik noemen:

- De personen die belangeloos hebben deelgenomen aan het onderzoek

- Prof. Dr. P.J. v.d. Lugt en Prof. Dr. F. Spaans, onder wier supervisie het onderzoek werd uittgevaerd

- Dr. L.H. Cuypers en Drs. F.A. Asin voor het verrichten van het urologisch onderzoek en de adviezen betreffende de bewerking van de urologische gegevens

- Ir. P. Leffers en Dhr. A.J. Vissers (vakgroep epidemiologie en gezondheidszorgonderzoek R.L.) voor hun vele adviezen en de statistische bewerking van de gegevens van dit onderzoek

- Drs. B. Kemp en Drs. P.G. Wuisman voor het ter beschikking stellen van de klinischneurofysiologische apparatuur

- Dr. Th.W. v.d. Wiel, Dr. A.M. Moers, Dr. J.L. Visser, Drs. H.N. Bron, Dr. L.P. Bos, Dr. L.G. Engels ${ }_{\|}$Drs. P.W. Frederiks, Drs. P.J. Geelen en Drs. H.M. Verhoeven, voor het motiveren van de diabetici om deel te nemen aan het onderzoek

- Mijn collegae Dr. L.A.H. Hagenhuis en Dr. J.J. Korten voor hun stimulans en ruime interesse in het onderzoek

- Mevr. R. Lensen-Hausmans en ing. J. Lensen voor het op uiterst zorgvuldige wijze uittypen van het manuscript en het belangeloos ter beschikking stellen van de tekstverwerkende apparatuur

- Mej. M. v.d. Velde en Dhr. H. Beeren voor hun hulp en steun bij het verrichten van het klinisch-neurofysiologisch onderzoek

- Dhr. P. Meuffels die het totale pakket aan illustraties verzorgde

- De Directie van het Maaslandziekenhuis voor de geboden steun.

Financiële bijdrage werd verstrekt door:

- BYK Nederland B.V.

- Diabetes Fonds Nederland

- Merck Sharp \& Dohme B.V.

- Ariëns Kappersfonds 
Aan: Els

Jan-Pletter

Marie-Paule

Monique 


\section{INHOUDSOPGAVE}

DEEL I: LITERATUURSTUDIE

Hoofdstuk 2 Literatuuroverzicht van de normale mictie en genitale functies 15

2.1. BEKKENBODEM EN ORGANEN. ALGEMEEN ........... 15

2.2. INNERVATIE VAN BLAAS; URETHRA EN GENITALIËN $\ldots . .17$

2.2.1. Perifere innervatie . . . . . . . . . . . . . . . . . . . . . . 17

2.2.2. Centrale innervatie ............................ 22

2.3. ADRENERGE EN CHOLINERGE RECEPTOREN IN DE URINEWEGEN EN GENITALIEN $\ldots \ldots \ldots \ldots \ldots \ldots \ldots \ldots 23$

2.4. FYSIOLOGIE VAN DE MICTIE ................. 25

2.5. FYSIOLOGIE VAN HET SEXUEEL FUNCTIONEREN ...... 32

2.6. FARMACOLOGIE ........................ 34

Hoofdstuk 3 Neurologische aspecten van diabetes mellitus in het kader van deze studie $\ldots \ldots \ldots \ldots \ldots \ldots \ldots \ldots$

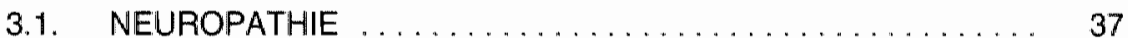

3.1.1. Somatische neuropathie $\ldots \ldots \ldots \ldots \ldots \ldots \ldots \ldots, 39$

3.1.1.1. Bilaterale (min of meer symmetrische) polyneuropathie ...... 39

3.1.1.2. Mononeuropathie en mononeuropathia multiplex ......... 40

3.1.2. Autonome neuropathie $\ldots \ldots \ldots \ldots \ldots \ldots \ldots \ldots \ldots . \ldots \ldots$

3.1.2.1. Cardiovasculaire systeem ..................... 41

3.1.2.2. Gastro-intestinale systeem $\ldots \ldots \ldots \ldots \ldots \ldots \ldots \ldots, 42$

3.1.2.3. Pupillen ............................... 43

3.1.2.4. Sudomotorische systeem $\ldots \ldots \ldots \ldots \ldots \ldots \ldots \ldots \ldots, 43$

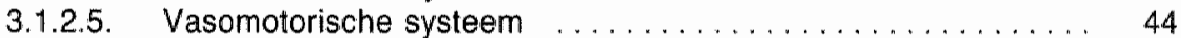

3.1.2.6. Endocriene systeem $\ldots \ldots \ldots \ldots \ldots \ldots \ldots \ldots \ldots \ldots, 44$

3.1.2.7. Urogenitale systeem $\ldots \ldots \ldots \ldots \ldots \ldots \ldots \ldots \ldots \ldots . \ldots \ldots$

3.2. MYELOPATHIE $\ldots \ldots \ldots \ldots \ldots \ldots \ldots \ldots \ldots \ldots \ldots \ldots$

Hoofdstuk 4 Literatuurgegevens betreffende de diagnostische onderzoekmethoden ....................... 51

4.1. KLINISCH-NEUIROFYSIOLOGISCHE METHODEN ........ 51

4.1.1. Elektromyografie van de $\mathrm{m}$. sphincter ani externus ........ 51

4.1.1.1. Inleiding ........................... 51

4.1.1.2. EMG parameters ........................ 51

4.1.1.3. Bevindingen bij diabetici ..................... 52

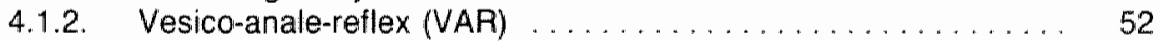

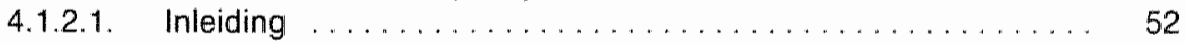

4.1.2.2. Traject van de VAR ...................... 53

4.1.2.3. Wijze van uitvoering van de VAR $\ldots \ldots \ldots \ldots \ldots \ldots \ldots, 54$

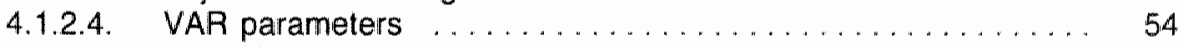

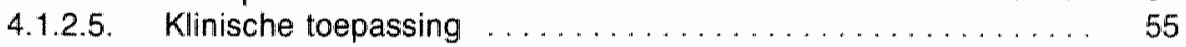

4.1.3. Bulbocavernosusreflex $(\mathrm{BCR}) \ldots \ldots \ldots \ldots \ldots \ldots \ldots \ldots \ldots \ldots$

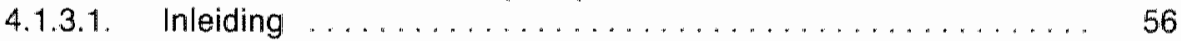




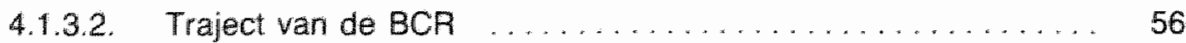

4.1.3.3. Wijze van uitvoering van de BCR ................ 57

4.1.3.4. BCR parameters ....................... 58

4.1.4. Tibialis/pudendus/pelvicus (hypogastricus) ewoked potentials . 59

4.1.4.1. Inleiding ............................. 59

4.1.4.2. Traject van de tibialis/pudendus/pelvicus (hypogastricus) evoked potentials

4.1.4.3. Wijze van uitvoering van somato-sensory evoked potentials ... 61

4.1.4.4. Configuratie en latentietijden van de SSEP ............ 62

4.1.4.5. Bevindingen bij diabetici ..................... 68

4.1.5. H-reflex . . . . . . . . . . . . . . . . . . . . . . . . . . 68

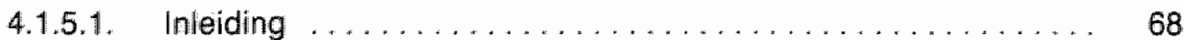

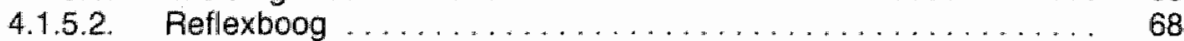

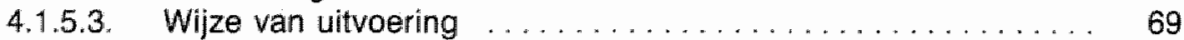

4.1.5.4. H-reflex parameters ........................ 69

4.1.5.5. Bevindingen bij diabetici .................... 69

4.1.6. Te verwachten stoornissen in de neurofysiologische tests bij letsels op verschillende niveaus van de urogenitale innervatie $\quad 70$

4.2. BESCHRIJVING UROLOGISCHE METHODEN .......... 71

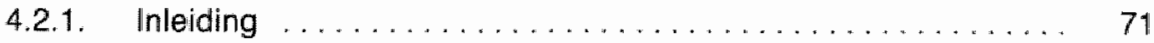

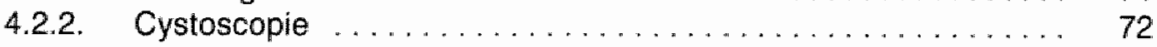

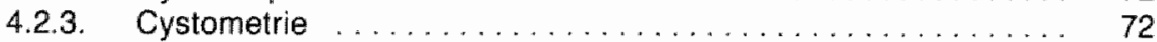

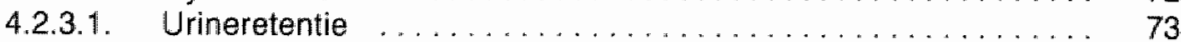

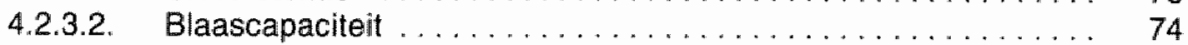

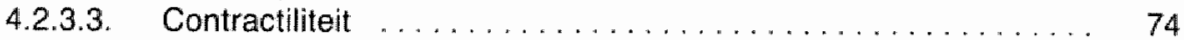

4.2.3.4. Sensibiliteit van de blaaswand . . . . . . . . . . . . . . 75

4.2.4. Uroflowmetrie .......................... 76

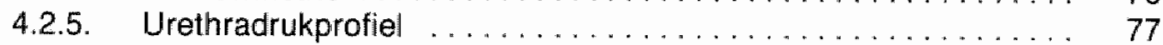

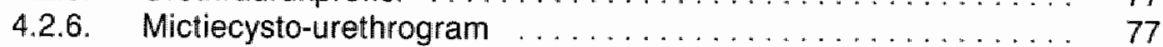

4.2.7. Elektromyografie ...................... 77

DEEL II: EIGEN ONDERZOEK

Hoofdstuk 5 Beschrijving onderzochte groepen $\ldots \ldots \ldots \ldots \ldots \ldots \ldots, 81$

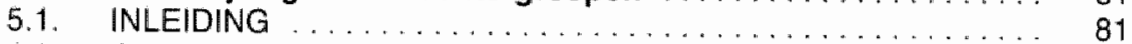

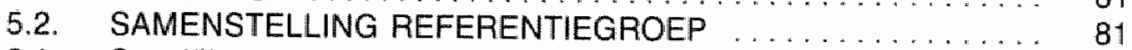

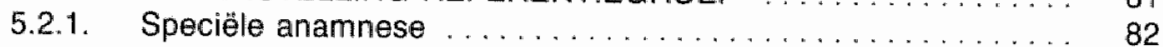

5.22 Aanvullende anamnestische gegevens ................ 83

5.2.3. Neurologisch onderzoek ....................... 83

5.2.4. Röntgendiagnostiek en laboratoriumonderzoek ............ 83

5.2.5. Lengte proefipersonen ....................... 83

5.3. SAMENSTELLING PATIENTENGROEP $\ldots \ldots \ldots \ldots \ldots \ldots \ldots . \ldots . \ldots$

5.3.1. Speciële anamnese .............................. 86

5.3.2. Aanvullende anamnestische gegevens . . . . . . . . . . . . 88

5.3.3. Neurologisch onderzoek ....................... 88

5.3.4. Röntgendiagnostiek en laboratoriumonderzoek ............ 89

Hoofdstuk 6 Methoden van onderzoek en onderzoekresultaten . . . . . 91

6.1. KLINISCH-NEUROFYSIOLOGISCH ONDERZOEK BIJ

REFERENTIE- EN PATIENTENGROEP

6.1.1. Elektromyografisch onderzoek $m$. sphincter ani externus ..... 91 
6.1.1.1.

Methode

6.1.1.2.

Resultaten

6.1.1.3.

Discussie

6.1.2.

Onderzoek van de vesico-anale-reflex (VAR)

6.1.2.1.

Methode

Resultaten

Discussie

100

6.1.3.

Onderzoek van de bulbocavernosusreflex $\|$ en $\|$ (BCA $\mid$ en $\|$ )

100

6.1.3.1.

Methode

100

6.1.3.2

Resultaten

100

6.1.3.3.

Discussie

108

6.1.4. Onderzoek van de tibialis/pudendus/pelvicus evoked potentials (resp. TEPIPEP/PHEP)

108

6.1.4.1.

Methode

108

6.1 .4 .2

Resultaten

109

6.1.4.3.

Discussie

119

6.1 .5

Onderzoek van de $\mathrm{H}$-reflex

119

6.1.5.1.

Methode

119

6. 1.5 .2

Resultaten

120

6.1.5.3.

Discussie

122

6.1.6. Regressie van de latentietijd van H-reflex, TEP en PEP

op geslacht, lengte en leeftijd bij referentiegroep

122

6.1.7. Samenvatting resultaten klinisch-neurofysiologisch onderzoek bij referentie- en patientengroep ................... 123

6.2. UROLOGISCH ONDERZOEK BIJ PATIENTENGROEP . . . . . 124

6.2.1.

6.2.2. Inleiding

6.2.2.1. Cystoscopie

Methode

6.2.2.2

Resultaten

125

6.2 .2 .3

Discussie

125

6.2 .3$.

Urodynamisch onderzoek

125

6.2.3.1.

Methode

125

6.2.3.2.

Resultaten

126

6.2.3.3.

Discussie

Hoofdstuk 7 Evaluatie klinisch-neurofysilologisch onderzoek bij patientensubgroepen op basis van anamnestische en urodynamische criteria en vice versa

7.1. LATENTIETIJDEN VAN REFLEXEN EN EVOKED POTENTIALS BUI SUBGROEPEN VAN DIABETICI MET UROGENITALE KLACHTEN EN/OF UIROLOGISCHE AFWIJKINGEN

7.1.1. Latentietijden van reflexen en evoked potentials bij diabetici met urogenitale klachten en/of urologische afwijkingen .......

7.1.2. Latentietijden van reflexen en evoked potentials bij patientensubgroepen op basis van gespecificeerde urogenitale klachten en urologische atwijkingen

7.1.3. Latentietijden van TEP en H-reflex ( $H-M$ interval) bij diabetici in relatie met de overige klinisch-neurofysiologische afwijkingen

7.1.4. Conclusies

7.2. AANTALLEN NORMALE EN AFWIJKENDE NEUROFYSIO- 
7.2.1. Waarschinlijke localisaties van verschillende laesies bij] patienten met diabetes mellitus

7.2.2. Aantallen normale en afwijkende neurofysiologische tests (VAR, BCR I, PEP) afzonderlijk en in combinatie bij diabetici met urogenitale klachten en/of urologische afwijkingen

7.2.3. Aantallen normale en afwijkende neurofysiologische tests (VAR, BCR I, PEP, PHEP) afzonderlijk en in combinatie bij] diabetici met urogenitale klachten en/of urologische afwijkingen

7.2.4. Aantallen normale en afwijkende neurofysiologische tests (VAR, BCR I, PEP) volgens het localisatiemodel bij patientensubgroepen op basis van gespecificeerde urogenitale klachten

7.2.5. Aantallen normale en atwijkende neurofysiologische tests (VAR, BCR I, PEP) volgens het localisatiemodel bij patientensubgroepen op basis van gespecificeerde urologische afwijkingen

7.2 .6$. Conclusies

Hoofdstuk 9 Samenvatting $\ldots \ldots \ldots \ldots \ldots \ldots \ldots \ldots \ldots \ldots \ldots$

Summary ........................... 171

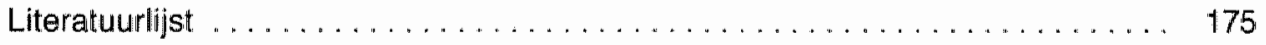

Appendices 


\section{INLEIDING}

Tot 20 jaar geleden stond de neuroloog slechts de anamnese en het neurologisch onderzoek ter beschikking om na te gaan of stoornissen van blaas, urethra en genitaliën door een neurologische aandoening werden veroorzaakt.

Het neurologisch onderzoek bestond uit het opwekken van reflexen, onder andere de anaalreflex, de bulbocavernosusreflex en de cremasterreflex, alsmede onderzoek van de sensibiliteit en de motoriek.

De uroloog onderzocht de functie van de blaas en de urethra door middel van cystometrie, uroflowmetrie, registratie van het urethradrukprofiel, sphincter elektromyografie en gecombineerde urodynamische studies. Deze methoden gaven informatie over de functie vari de blaas en urethra maar slechts in beperkte mate over de innervatie van de blaas en de urethra.

De laatste 20 jaren heeft een aantal onderzoekers tests ontwikkeld om de innervatie van de blaas, de urethra en de genitalien objectief te onderzoeken. Markland et al. (1972) en Jelasic et al. (1975) stimuleerden sacrale wortels met behulp van een naaldelektrode, doch deze methoden waren niet geschikt voor de dagelijkse praktijk.

Bradley introduceerde in 1972 een in de kliniek geschikte test. Hij stimuleerde het proximale deel van de urethra door middel van een katheter, waarop twee stimulatieelektroden waren aangebracht. Het reflexantwoord van de $\mathrm{m}$. sphincter ani externus werd afgeleid met oppervlakte-elektroden op een anale plug.

Rusworth (1967), Haldeman et al. (1982) en Vodusek et al. (1982) hebben de latentietijd van de bulbocavernosusreflex gemeten bij stimulatie van de $n$. dorsalis penis en deze geregistreerd door middel van een concentrische naaldelektrode in de $\mathrm{m}$. bulbocavernosus. In de jaren tachtig hebben diverse auteurs (Kaplan, 1981; Haldeman et al., 1982; Badr et al., 1982) aangetoond dat na stimulatie van de $\mathrm{n}$. pudendus (in. dorsalis penis of $\mathrm{n}$. clitoridis) en $n$. pelvicus door middel van oppervlakte-elektroden, een evoked potential op het hoofd geregistreerd kon worden.

Door het toepassen van deze methoden kan de integriteit van enkele centrale en perifere verbindingen, die een ral spelen bij de mictie en de genitale functies, beoordeeld worden en door het combineren van deze onderzoeken kan deze informatie aanzienlijk vergroot worden.

In de jaren 1981 en 1982 hebben wij deze neurofysiologische onderzoekmethoden gestandaardiseerd en normaalwaarden bepaald. In de periode 1982 tot en met 1984 werden 80 patienten mel diabetes mellitus, die deels insuline en deels niet insuline afhankelijk waren, middels deze neurofysiologische onderzoekmethoden onderzacht.

Wij kozen voor patienten met diabetes mellitus, omdat dit ziektebereld frequent voorkomt en bij ceze ziekte vaak neurologische afwijkingen worden gevonden in de zin van een perifere neuropathie, zowel van het autonome als van het somatische zenuwstelsel, of een ruggemerglijden. Uit literatuuronderzaek en een pilotstudy bleek dat mictie- en sexuele functiestoornissen regelmatig voorkwamen (Rundles, 1945; Rubin en Babboth, 1958; Ellenberg, 1971; Frimodt-Møller, 1976b).

Het voorkomen van cystoneuropathie bij insuline afhankelijke diabetici onderzocht met behulp van cystometrie, meting van het urethradrukprofiel, uroflowmetrie, drukflowmeting en elektromyogratie, wordt in de literatuur opgegeven tussen de $26 \%$ (Rundles, 1945) en 87\% (Faerman et al., 1971).

De in de literatuur opgegeven frequentie van potentiestoornissen bij diabetici varieert van 15 tot 75\% (Rundles, 1945; Rubin en Babboth, 1958; Aagenaes, 1963; Schöffling et al., 
1963; Faerman et al., 1969, 1971, 1974; Ellenberg, 1971; Reed et al., 1973; Frimodt-Møller, $1976 \mathrm{~b}$ en Fagerberg et al., 1967 ).

Gegevens over sexuele stoornissen bij de vrouwelijke diabetici zijn er nauwelijks.

Biij pathologisch anatomisch onderzoek vonden Dolman (1963), Riedel (1965) en Slager (1978) een achterstrenglaesie bij $17 \%$ tot $44 \%$ van de onderzochte diabetici.

Uit literatuuronderzoek van de anatomie en fysiologie blijkt, dat specifieke laesies van de innervatie van het urogenitale systeem reeds vast te stellen zijn bij het afnemen van de anamnese (Wijndaele en De Sij, 1980). Of via de anamnese betrouwbare informatie verkregen wordt over de localisatie van de laesie bij patienten met diabetes mellitus is weinig bekend.

Het doel van het onderzoek is om door middel van klinisch-neurofysiologisch onderzoek na te gaan of er innervatiestoornissen van het urogenitale systeem aantoonbaar zijn, deze te lacaliseren en de resultaten te vergelijken met die van het urodynamisch onderzoek enerzijds en de anamnese van mictiestoornissen en/of sexuele functiestoornissen anderzijds. 
DEEL I:

LITERATUURSTUDIE 


\section{LITERATUUROVERZICHT VAN DE NORMALE MICTIE EN GENITALE FUNCTIES}

\subsection{BEKKENBODEM EN ORGANEN ALGEMEEN}

\section{DE BEKKENBODEM}

De bekkenbodem is opgebouwd uit twee diaphragmata. Het diaphragma pelvis bestaat uit de $\mathrm{m}$. levator ani en $\mathrm{m}$. coccygeus. De origo van de $\mathrm{m}$. levator ani is het os pubis, de arcus tendineus van de $\mathrm{m}$. levator ani en de spina ischiadica. De insertie is het os coccygis (onderste twee segmenten), de raphe anococcygeum, de $\mathrm{m}$. sphincter ani externus en het centrum tendineum perinei (bindweefsel lichaam).

De $\mathrm{m}$. levator ani is opgebouwd uit de $\mathrm{m}$. pubococcygeus en $\mathrm{m}$. iliococcygeus. Tussen beide $\mathrm{mm}$. pubococcygei ligt de hiatus genitalis. Hier lopen de urethra, de vagina en het rectum doorheen.

Het tweede diaphragma, het diaphragma urogenitale, bestaat uit twee fascies, die de $\mathrm{m}$. transversus perinei profundus en de $\mathrm{m}$. sphincter urethrae externus omsluiten. Het is driehoekig van vorm en ligt tussen de rami inferiores ossis ischii en pubil. Dorsaal vormen de twee fascies een krachtig bindweefsel lichaarn, thet centrum tendineum perinei. Hieraan zijn verbonden de $\mathrm{m}$. levator ani ( $\mathrm{m}$. pubococcygeus), het ventrale deel van de $\mathrm{m}$. sphincter ani externus, de $\mathrm{m}$. bulbocavernosus, de $\mathrm{m}$. transversus peronei profundus en superficialis. De insertie van de $\mathrm{m}$. bulbocavernosus is het dorsum penis en het dorsale gedeelte van de bulbus penis. De overeenkomstige spier bij de vrouw heeft zijn insertie aan het dorsum clitoridis en het corpus cavernosum clitoridis.

\section{DE BLAAS}

Aan de blaas onderscheidt men de apex of vertex, het corpus en de fundus. De wand van de blaas is opgebouwd uitt een mucosa, een submucosa, een tunica muscularis en een tunica adventitia.

De tunica muscularis van de blaas en de blaashals bestaat uit 3 lagen glad spierweefsel, t.w. een buitenste met een longitudinale rangschikking van de spiervezels, een middelste met circulaire en een binnenste met weer een longitudinale rangschikking.

Deze drie spierlagen kunnen slechts in het gebied van de blaashals goed onderscheiden worden. In het overige deell van de blaas lopen de spiervezels van deze lagen door ellkaar heen en vormen een gecompliceerd vlechtwerk. Tanagho en Smith (1968) en Hauri (1978) maakten aannemelijk dat de buitenste spierlaag zich verenigt met het diaphragma urogenitale om vervolgens in de vorm van een dubbele spiraal de buitenste spierlaag van de urethra te vormen. De middelste spierlaag zou dan eindigen in de blaashals in de vorm van een plaat, die bestaat uit concentrisch rond de blaasuitgang gerangschikte vezels. De binnenste spierlaag zou zich uitstrekken buiten de blaashals, en zo de binnenste longitudinale spierlaag van de urethra vormen.

Anderen menen dal de gladde spier van de urethra ten opzichte van de blaasmusculatuur een geheel onafhankelijk systeem is (Uiden, 1975; Donker et al., 1976).

\section{HET TAIGONUM EN DE BLAASHALS}

Het trigonum is hel gebied aan de achterzijde van de blaaswand tussen de twee ureter openingen en de interne blaasopening.. De binnenste twee spierlagen van de ureteren gaan over in de musculatuur van het trigonum. De buitenste spierlaag van de ureteren waaiert uit in de submucosa van het trigonum en vormt de $\mathrm{m}$. trigonalis (Hofman, 1969). Gosling $(1979,1985)$ vand dat de gladde spier in het trigonum uit twee delen bestaat: een oppervlakkige en een diepe $\mathrm{m}$. trigonalis. 
Het diepe deel is niet te onderscheiden van de m. detrusor. Gosling noemt dit diepe deel de trigonale detrusorspier en het oppervlakkige deel de m. trigonalis. Dit is een dunne laag. die ult betrekkelijk kleine spierbundels is opgebouwd.

Deze dunne spier strekt zich bij de man uit tot het verumontanum; bij de vrouw waaiert hij uit in het proximale deel van de urethra. Deze spier speelt volgens Tanagho en Smith (1968) en Gosling (1979) een rol bij het openen en sluiten van de ureteropening in de blaas.

Aan de buitenzijde van het caudale gedeelte van het trigonum bevinden zich vollgens Hofman (1969) transwersaal gerangschikte gladde spiervezels. Deze vormen de bekleding van het dorsale deel van de blaashals en eindigen in de ventrolaterale wand van de urethra prostatica. De functie van deze spiervezels is thet sluiten van de blaashals gedurende de ejaculatie en heeft geen betekenis voor het handhaven van de continentie (Hofman „1969). Gosling $(1979,1985)$ beschreef bij de man een circulaire kraag van gladde spiervezels (m. sphincter urethrae internus), die de blaashals volledig omgeeft. Deze gladde spiervezels breiden zich uit naar het preprostatische deel van de urethra en het prostaatkapsel "en woorkomen bij contractie een retrograde ejaculatie.

Bij de wrouw is geen circulaire kraag aanwezig. De spierbundels hebben hier een schuin of longitudinaal verloop en zij breiden zich uit tot in het bindweefsel dat de meatus urethrae externus omgeeft. Welke rol deze gladde spiervezels spelen bij het handhaven van de continentie is volgens Gosling (1985) niet duidelijk bekend.

\section{DE URETHRA}

De mannelijke urethra bestaat uit een pars prostatica, een pars membranacea en een pars cavernosa. De wand van de urethra is opgebouwd uit een mucosa, een submucosa en een tunica muscularis.

In het losmazige bindweefsel van de submucosa bevinden zich elastisch weefsel en bloedvaten die door hun druk het lumen van de urethra membranacea tot $1 / 4$ kunnen reduceren. Dit mechanisme zou van belang zijn voor het handhaven van de continentie. De tunica muscularis is opgebouwd uit een binnenste longitudinale en buitenste circulaire spierlaag.

Volgens Hauri (1978) bestaat de dwarsgestreepte m. sphincter urethrae (m. sphincter urethrae externus) uit twee delen. Ten eerste een echte sphincter, die de pars membranacea omcirkelt en in het diaphragma urogenitale ligt. Het tweede gedeelte wordt gevormd door bundels verticaal gerangschikte spiervezels, die naar de blaashals lopen en het distale deell van de achterzijde van de urethra als een mantel omwikkelen. Deze dwarsgestreepte spiervezels komen in contact met de gladde spiervezels van de urethra door middel van zeer fijne verbindingen. Dit zijn histologisch gezien ligamenten van collageen bindweefsel (Hauri, 1978).

Donker et al. $(1976)$ en Gosling $(1979,1985)$ beschrijven eveneens bij de man circulair gerangschikte dwarsgestreepte spiervezels, die de pars membranacea van de urethra volledig omsluiten. Deze spiervezels zijn 'slow twitch' vezels en zijn volledig gescheiden van de peri-urethrale dwarsgestreepte musculatuur die de bekkenbodemmusculatuur vormt. Deze laatste musculatuur bevat 'slow' en 'fast twitch' vezels.

Ook bij de vrouw is er een dwarsgestreepte $\mathrm{m}$. sphincter urethrae aan de buitenzijde van de gladde musculatuur. Deze sphincter heeft de grootste omvang ter hoogte van het middelste deel van de urethra en strekt zich vooral aan de voorzijde uit zowel naar distaal als naar proximaal. Aan de achterzijde vormt deze spier slechts een dunne laag. Evenals bij de man bevat deze spier 'slow twitch' vezels en is hij gescheiden van de peri-urethrale dwarsgestreepte musculatuur van de bekkenbodem die 'slow' en 'fast twitch' vezels bevat.

Neurofysiologische studies bij de kat (Bowen et al., 1976) toonden echter alleen 'fast twitch' vezels aan in de intramurale dwarsgestreepte urethramusculatuur.

Een deel van het prostaatkapsel wordt gevormd door gladde en dwarsgestreepte spiervezels. De prostaat is ingebed tussen de buitenste spiraalvormige spierlaag en de binnenste longitudinale spierlaag van de urethra. Distaal van het diaphragma urogenitale 
wordt op het urethrogram bij de man regelmatig een wernauwing gezien. Morales en Romanus (1953) dachten dat deze vernauwing werd veroorzaakt doot de $\mathrm{m}$. compressor nudae, die volgens hen een deel is van de $\mathrm{m}$. bubocavemosus.

\section{HET RECTUM}

Het rectum begint ter hoogte van de overgang van de tweede naar de derde sacrale wervel en eindigt bij de canalis analis ter hoogte van het proximale deel os coccygis. De spierlaag van de wand wan de canalis analis is opgebouwd uit een buitenste longitudinale en een binnenste circulaire laag van glad spierweefsel. De binnenste laag en in mindere mate de buitenste laag wormen samen ter hoogte van het distalle deel van de canalis analis de $\mathrm{m}$. sphincter ani internus. De dwarsgestreepte $\mathrm{m}$. sphincter ani externus omcirkelt de $\mathrm{m}$. sphincter ani internus en wordt verdeeld in een pars profunda, een pars superficialis en een pars subcutanea. De $\mathrm{m}$. sphincter ani externus is trechtervormig. De rand van de trechter wordt gevormd door de pars profunda welke zich verenigt met de $\mathrm{m}$. levator ani en het centrum tendineum perinei. De pars superficialis is stevig aangehecht aan het os coccygis en het centrum tendineum perinei. De pars subcutanea. wordt gevormd door kruisende vezels voor en achter de anus.

\section{DE GENITALIEN}

De testikels worden amgeven door een bindweefsellaag, de tunica albuginea testis. De testis wordt verdeeld in compartimenten, de lobuli testis. Deze zijn van elkaar gescheiden doar incomplete septa. In deze compartimenten liggen de tubuli contorti seminiferi. Zij beginnen blind, zijn ingebed in fijnvezelig, sterk vochthoudend bindweefsel, hebben een extreem kronkelig verloop en lopen naar de bovenpool van de testis. Hun eindigingen hebben een recht verloop. De tubuli recti gaan over in een netwerk. Hieruit ontstaan tien tot twaalf buisjes, de ductuli deferentes genoemd. Juist boven de prostaat, na het samengaan van de ductus deferens met de vesicula seminalis, ontstaat de ductus ejaculatorius. Deze loopt door de prostaat en komt, samen met die van de andere zijde, uit aan weerszijden van de utriculus masculinus gelegen in het achterste deel van de urethra.

De penis is opgebouwd uit drie cylindervormige ruimten van caverneus erectiel weefsel; twee dorsaal gelegen corpora cavernosa penis en én ventraal gelegen corpus caverno sum urethrae (corpus spongiosum penis). Door het corpus spongiosum penis loopt de urethra, die eindigt in de glans penis.

De vrouwelijke genitaliën worden onderscheiden in de uitwendige geslachtsdelen (mons pubis, labia majora en minora pudendi, clitoris, vestibulum vaginal, en hymen) enerzijds en de inwendige (ovaria, tubae uterinae, uterus en vagina) anderzijds. Het hymen vormt de scheiding tussen de inwendige en uitwendige geslachtsdelen. De clitoris bestaat uit het corpus clitoridis, de glans clitoridis en de beide crura clitoridis. Het orgaan bestaat uil caverneus weefsel dat is opgehoopt in de twee corpora cavernosa clitoridis. Een corpus spongiosum ontbreekt.

\subsection{INNERVATIE VAN BLAAS, URETHRA EN GENITALIËN}

\subsubsection{PERIFERE INNERVATIE}

\section{SPINAAL}

De blaas en de urethra worden geïnnerveerd door het autonome zenuwstelsel (parasympathisch en sympathisch) en het willekeurige zenuwstelsel (figuur 2.1).

De parasympathische preganglionaire neuronen, die de blaas en de $\mathrm{m}$. sphincter urethrae internus innerveren, vinden hun oorsprong in de nuclei intermedii lateralis van de segmenten $S 2$ tot en met $\$ 4$ van het ruggemerg. De parasympathische innervatie van de $\mathrm{m}$. sphincter ani internus vindt plaats vanuit het eerste tot en met derde sacrale 
segment (Schuster, 1968). Schlyvitsch en Kosintzew (1939) toonden aan, dat de meeste parasympathische vezels bif de mens ontspringen uit de segmenten S3 en S4. De preganglionaire parasympathische vezels verlaten het ruggemerg door de voorhoorn via de ventrale spinale wortel. Dichtbil de wervelkolom splitsen de autonome vezels zich af van de spinale zenuw en vormen een afzonderlijke parasympathische zenuw, de n. pelvicus. Deze innerveert het onderste gedeelte van het colon descendens, het rectum, de blaas en de voortplantingsorganen behalve het ovarium.

De cellichamen van de postganglionaire vezels liggen dichtbij of zelfs in de eindorganen. De neurotransmitter welke door deze vezels wordt afgegeven is acetylcholine.
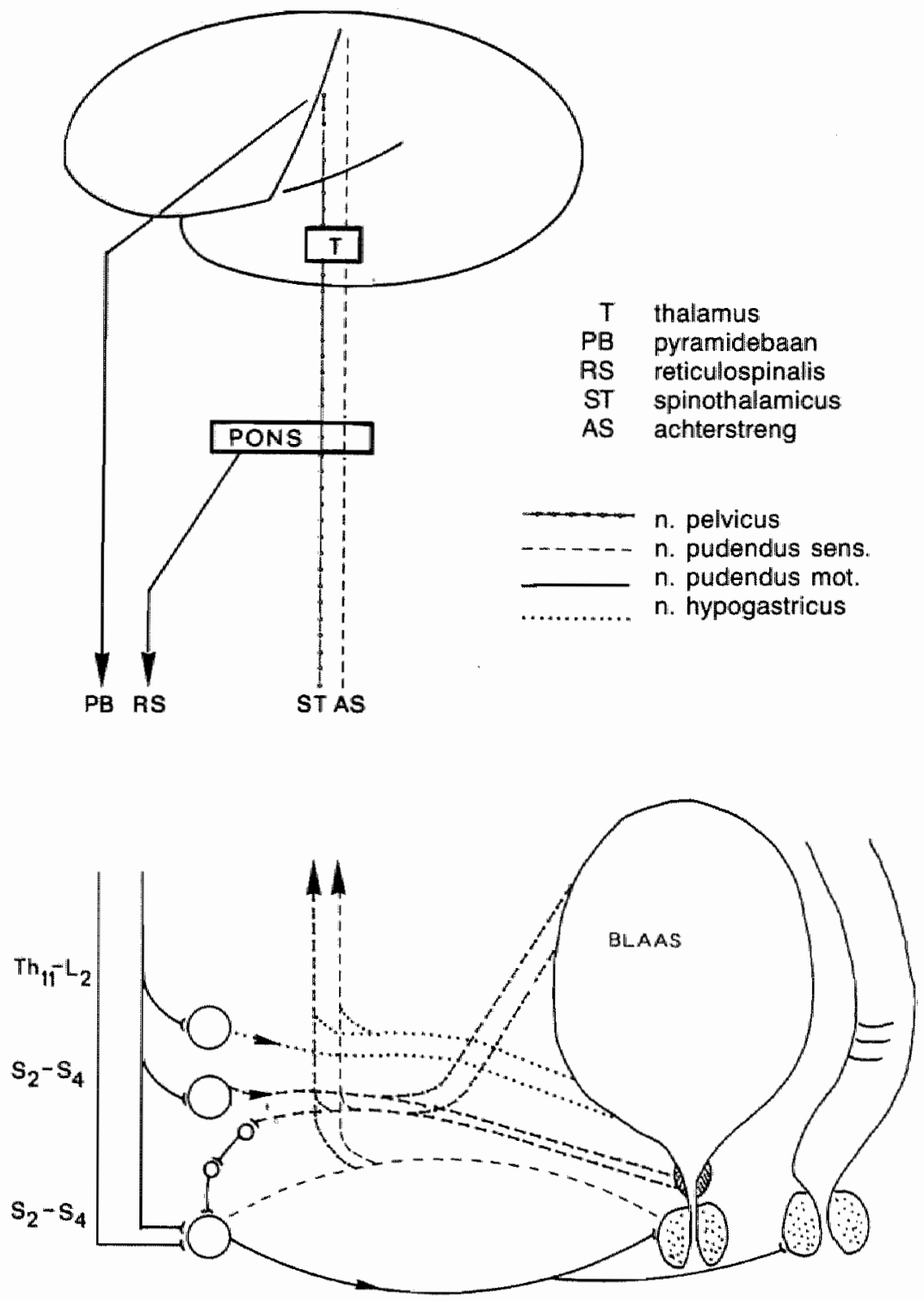

Figuur 2.1.

Perifere en centrale innervatie van blaas, urethra en genitaliën. 
De sympathische innervatie van de blaas, de urethra en een deel van de voortplantingsorganen vindt vanuit drie bronnen plaats.

De eerste bron wordt gevormd door meuronen in de zijhoorn van de ruggemergssegmen. ten Th11 tot $L 2$. Sympathische preganglionaire vezels verlaten het ruggemerg via de ventrale spinale wortel. De vezels vormen, na uittreding uit het foramen intervertebrale, de ramus communicans albus en treden binnen in de paravertebrale ganglia, die onderdeel zijn van de grensstreng. De preganglionaire vezels lopen eveneens zonder synaps als n. splanchnicus door naar de prevertebrale ganglia (het ganglion coellacum en het ganglion mesentericum superior en inferior). De vezels naar de blaas synapteren uiteindelik in het ganglion mesentericum inferior en lopen naar de plexus pelvicus.

Een tweede bron vormen de paravertebrale ganglia L3-L4 van de grensstreng. De postganglionaire vezels lopen eveneens naar de plexus pelvicus.

De derde bron wordt gevormd door de paravertebrale ganglia L5 tot en met S3 van de grensstreng. Ook van hieruit gaan postgangllionaire vezels direct naar de plexus pelvicus. Dit is een gemengde plexus ter hoogte van de prostaat, blaashals en rectum gelegen. Deze bevat tevens parasympathische vezels uit de $n$. pelvicus.

Volgens Schuster (1968) vindt de sympathische innervatie van de $\mathrm{m}$. sphincter ani internus vooral plaats vanuit het vijfde lumbale paravertebrale ganglion.

De neurotransmitter welke door de sympathische postganglionaire vezels wordt afgege ven is noradrenaline.

Sjöstrand vond in 1962 bij verschillende proefdieren en bij de mens ganglièn met groepjes adrenerge cellichamen, vlakbij de ductus deferens, prostaat en vesiculae seminales. Deze adrenerge cellichamen dichtbij de effector worclen korte adrenerge neuronen genoemd. Deze werden ook in het trigonum vesicae gevonden (Swedin, 1971).

De plexus pelvicus gaat over in de plexus vesicalis, gelegen aan het laterale oppervlak van de blaas, en innerveert de blaas. De urethra bij de man wordt geïnnerveerd door de plexus prostaticus. Bij de vrouw wordt de urethra direct door de plexus vesicalis geïnnerveerd. Uit de plexus prostatiicus ontstaan de nervi cavernosi, die langs de urethra naar de penis of het vestibulum lopen. Vanuit deze plexus worden bovendien het rectum en de voortplantingsorganen, uitgezonderd het ovarium, geïnnerveerd. Het ovarium ontvangt postganglionaire sympathische vezels uit de plexus ovaricus en plexus remalis. Het vas deferens, de epididymis en de testikel worden ook geïnnerveerd door de plexus spermaticus. Takken van de plexus vesicalis splitsen zich in de adventitia van de blaas ( $\mathrm{n}$. vesicalis). Zij zetten zich voort naar het bovenste deel en de voor- en achterzijde van de blaas en doorboren de tunica muscularis. Deze zenuwen worden steeds dunner door vertakkingen en verspreiden zich door de tunica muscularis en de submucosa van de blaas. Onderzoek bij de kat toont aan, dat gemyeliniseerde vezels in de blaaswand schaars zijn (minder dan 0,5\%) (Uemura et al., 1974 en 1975). Zij zijn alleen aanwezilg in dle grote nervi vesicales.

In de blaaswand hebben de zenuwen een gekronkeld verloop. Bij blaasvergroting worden zij gestrekt. Alle zenuwen in de bllaas, behalve de kleinste, zijn omgeven door één of meer lagen perineuraal epitheel en de niet gemyeliniseerde zenuwen zijn ingebed in een Schwannse schede. De kleinste zenuwen bestaan uit bundels van gewoonlijk minder dan vijf axonen, omgeven door een enkele cel van Schwann per lengte segment. Deze kleinste zenuwen liggen vooral in de blaashals. In de blaaswand liggen zij het meest in het trigonum en in mindere mate in het corpus en de apex.

Histologisch onderzoek van de ramus communicans albus, grensstreng en $\mathrm{n}$. splanchnicus bij katten door Ranson en Billingsley (1918b) en later Mc Leod (1958) toonde twee pieken in het vezeldiameterhistogram: één piek bij 2 tot $3 \mu \mathrm{m}$ en éen bij 9 tot $10 \mu \mathrm{m}$. Waarschijnlijk hebben de afferente vezels een grote diameter en de gemyeliniseerde preganglionaire efferente vezels een kleine diameter. De vezeldiameter van de grensstreng, ramus communicans albus en $n$. splanchnicus werd ook bestudeerd bij de mens (Appenzeller en Ogin, 1974; Low et al., 1975). Ook hier werden twee pieken in het vezeldiameterhistogram gevonden. Eén bij 2 tot $6 \mu \mathrm{m}$ en één in het gebied boven de $12 \mu \mathrm{m}$. 
De dikke gemyeliniseerde vezels en enkele wan de dunne zifn afferent. De samengestelde actiepotentiaal unt de n. splanchnicus major bij stimulatie van de grensstreng bij de kat bestaat uit de volgende componenten:

- een A-betagolf, die de dikste gemyeliniseerde vezels vertegenwoordigt met een maximale geleidingssnelheid van 70 tot $75 \mathrm{~m} / \mathrm{s}$

- Een kleine A-gammagolf met een maximale geleidingssnelheid van 30 tot $35 \mathrm{~m} / \mathrm{s}$

- een grote $\mathrm{B}$-golf met een maximale geleidingssnelheid van 10 tot $12 \mathrm{~m} / \mathrm{s}$ én

- een Cogoll, die de geleiding in de niel gemyeliniseerde vezels vertegenwoordigt en die een maximale geleidingssnelheid heeft van 1 tot $2 \mathrm{~m} / \mathrm{s}$ (Post en Mc Leod, 1977a).

De geleidingssnelheden wan de individuele veze $s$ in de $n$. hypogastricus en n. pelvicus bil de kat zijn minder dan $15 \mathrm{~m} / \mathrm{s}$ (DeGroat en Lalley, 1972). Oliver et al. (1969) vonden bij katten in de sympathische wezels een maximale gelleidingssnelheiid van $13 \mathrm{~m} / \mathrm{s}$.

ledere efferente eindtak eindigt in multipele synapsknopjes. De breedte van de synapsspleten varieert sterk. Er zijn twee typen van efferente synapsknopjes in de blaas. Aan de uiteinden van de postganglionaire parasympathische axonen wordt acetylcholine afgescheiden en aan de uiteinden van de postganglionaire orthosympathische axonen als regel noradrenaline en een weinig adrenaline.

De chollinerge vezels bevinden zich in alle delen wan de blaas en de adrenerge zijn voornamelijk geconcentreerd in de blaashals. Alle viscerale vezels kruisen en innerveren de contralaterale zijde van de blaas.

De laatste jaren is aangetoond dat de cholinerge en adrenerge zenuwen die de blaas, urethra en genitaliën innerveren, naast acetylcholine en noradrenaline ook andere transmitters in verschillende combinaties en hoeveelheden afscheiden, zoals ATP en peptiden. Het effect van de transmitters op het urogenitale systeem kan exciterend, inhiberend of afwezig zijn (Burnstock, 1986; Andersson, 1986).

De cellichamen van de willekeurige efferente neuronen liggen in de voorhoorn van de ruggemergssiegmenten $\mathrm{S} 2$ tot en met $\mathrm{S} 4$.

De zenuwvezels van deze kernen verlopen in de plexus en de n. pudendus. Nadal de $n$. pudendus het kanaal van Alcock heeft verlaten, scheidt de $n$. analis zich af. Deze bevat vezels voor de $\mathrm{m}$. sphincter anil externus. De n. pudlendus verdeelt zich daarna in twee takken: een gemengde $n$. pudendus dorsalis of $n$. clitoridis en een $n$. perinealis welke zich splitst in een gemengde diepe en een sensibele oppervlakkige tak. De n. pudendus en zijn takken innerveren de bekkenbodemmusculatuur. Bovendien beval de n. pudendus sensibele vezels die een deel van de huid wan het scrotum innerveren.

Vereecken en Verduyn (1970), De Jonge (1976) en Blaivas en Labil (1976 en 1977) toonden aan dat de $\mathrm{m}$. pubococcygeus, de $\mathrm{m}$. transversus peronei profundus en superficialis, de $\mathrm{m}$. sphincter ani externus en de m. sphincter urethrae externus onathankelijk van elkaar kunnen contraheren en relaxeren. Dit ziet men vooral bij patienten met myelumlaesies zoals bij multiple sclerose en myelodysplasie, maar ook bij normale individuen. Ook Ruskin en Davis (1969) meldden een onafhankelijke functie bij normale mensen.

Percy et al. (1981) toonden bij de mens aan dat de innervatie van de $\mathrm{m}$. sphincter ani externus sterk gelateraliseerd is. Bishop (1959), wond bij de kat na eenzijdige stimulatie van de $n$. pudendus, elektromyografische activiteit in beide delen van de m. sphincter ani externus. Gunterberg (1976) vond bij de mens na eenzijdige doorsnijding van de n. pudendus dat de elektromyografische activiteit aan de gelaedeerde zijde slechts weinig vermindierd was. Wunderlich en Swash (1983) vonden door middel wan histologisch on-

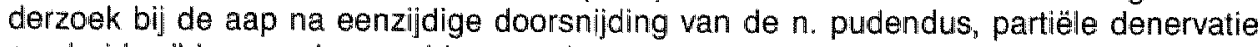
aan beide zijden van de $\mathrm{m}$. sphincter ani externus, maar meer uitgesproken ipsi- dan comtralateraal. Ook re-innervatie na eenzijdige doorsnijding van de n. pudendus kwam voor aan beide zijden, vooral in het voorste en laterale deel. Zowel bij de aap als bij de mens kruisen spierwezels zowel aan de voor- als achterzijde de mediaanlijn. Bij de mens mogelijk tot halverwege de sphincterhelft. 
Onuf beschreef in 1901 een specifieke groep neuronen in het sacrale merg bij de mens: de nucleus van Onuf of groep $X$ van Onuf. Deze nucleus ligt in de voorhoorn van vooral het tweede sacrale segment en breidt zich uit naar het onderste deel van het eerste sacralle segment en het bovenste deel van het derde sacrale segment.

Schröder (1981) vond in de nucleus drie celgroepen: een craniale, een ventrolaterale en een dorsomediale.

Volgens Chou et al. (1982) is de nucleus opgebouwd uit kleine neuronen in tegenstelling tot de motorische nuclei die lateraal en mediaal van deze nucleus gelegen zijn en grote neuronen bevatten. Chou et al. (1982) ontdekten door retrograde "tracing' dat de nucleus van Onuf de $\mathrm{m}$. sphincter urethrae externus, de $\mathrm{m}$. sphincter ani externus, de $\mathrm{m}$. bulboca. vernosus en de $\mathrm{m}$. ischiocavernosus innerveert. De nucleus zou alleen een somatomotorische en geen autonome functie hebben, zoals eerder werd gedacht.

\section{GANGLIA VAN DE BLAASWAND}

Macroscopische en microscopische ganglia zijn aanwezig langs de zenuwtakken en vertakkingen van de plexus vesicalis. De ganglia van de plexus vesicalis zijn sympathisch, parasympathisch of gemengd. De parasympathische ganglia zijn talrijker dan de sympathische. De grootste ganglia van de blaas liggen in de adventitia van de fundus. De kleinste, die uit enkele cellichamen zijn opgebouwd, liggen in de tunica muscularis of submucosa (Fletcher et al., 1969). Ganglia worden overigens in alle delen wan de blaaswand aangetroffen, doch voornamelijk in de fundus.

\section{DE AFFERENTE VEZELS VAN DE BLAAS}

De afferente vezels van de blaas beginnen als vrije zenuwuiteinden (voornamelijk spierreceptoren), maar ook als corpuscula lamellosa (Pacini). De vrije zenuwuiteinden zijn vertakt en hebben bij een lege blaas een gekronkeld verloop. Zij kunnen omgeven zijn door cellen van Schwann. Deze functionele mechanoreceptoren van de afferente zenuwen zijn morfologisch niet te onderscheiden van de geleidende axonen met welke zij verbonden zijn. De sacrale afferente vezels zijn verspreid door de gehele blaaswand en urethra, echter meer in de tunica muscularis dan in de submucosa. De lumbale afferente vezels lig. gen ook in de gehele blaas, maar vooral in het trigonum en in het voorste deel van de blaashals. Zij liggen meer in de submucosa dan in de tunica muscularis. Ongeveer 30 $\%$ van de afferente vezels kruist in de blaaswand. Sommige van de lumballe vezels kruisen echter op het niveau van de plexus hypogastricus (DeGroat en Lalley, 1972). Ook de sacrale afferente vezels kruisen in de blaaswand (Oliver et all., 1970). De imvloed van één $\mathrm{n}$. pelvicus is voomamelijk beperkt tot de homolaterale zijde van de blaaswand. Lumbale afferente zenuwen komen in de submucosa 3,7 maal zo vaak voor als de sacrale afferente zenuwen; in de spier van de blaas daarentegen komen sacrale afferenten 2,3 maal zo vaak woor als de lumbale (Uemura et al., 1975). Sacrale afferenten zijn 2,6 maal zo talrijk in het bindweefsel dat de spierfascikel omgeeft, als in het schaarse endomysium binnen de spierfascikel.

Op grond van morfologische waarnemingen hebben Fletcher et al. (1969) de hypothese opgesteld, dat receptoren buiten de fascikel spanningsreceptoren zijn en binnen de fasci. kel volume- of lengtereceptoren. Deze spannings-en lengtereceptoren zijn vrije zenuwuiteinden en zijn aspecifiek in hun morfolagie. Een uitzondering hierop zijn de lichaampjes van Pacini. Bij fysiologisch onderzoek zijn lengtereceptoren nog niet aangetoond.

De geleidingssneltheden van de sacrale afferente vezels in de $n$. pelvicus komen overeen met die van gemyeliniseerde vezels (Oliver et al., 1969).

Patton (1960) toonde een piek van $2-5 \mu \mathrm{m}$ (A-delta) vezels aan in het vezeldiameterhistogram van afferente vezels van de $n$. pelvicus bij katten. Dit vezeldiameterhistogram werd ook gevonden in de $n$. vagus en de $n$. splanchnicus. Hoewel een minderheid van de individuele vezels sneller geleidt dan $16 \mathrm{~m} / \mathrm{s}$, heeft het grootste deel van de vezels geleidingssnelheden die overeenkomen met die van niet gemyeliniseerde vezels. De geleidingssnelheid van de lumbale afferente vezels bedraagt minder dan $16 \mathrm{~m} / \mathrm{s}$. De niet gemyeliniseerde vezells geleiden met snelheden van minder dan $6 \mathrm{~m} / \mathrm{s}$. 


\section{DE INNERVATIE VAN DE URETHRA}

De urethra wordt bij de man geinnerveerd door de plexus prostaticus vanuit de plexus vesicalis. Bif de vrouw wordt de urethra direct door de plexus vesicalis geinnerveerd. De parasympathische en sympathische vezels eindigen in de $\mathrm{m}$. sphincter urethrae internus. Volgens Gosling $(1979,1985)$ geschiedt de innervatie van de $\mathrm{m}$. sphincter urethrae internus bij de man door middel van noradrenerge sympathische en bij de vrouw door parasympathische vezels. De meningen over de exacte innervatie van de $\mathrm{m}$. sphincter urethrae externus zijn in de loop der jaren aan verandering onderhevig.

Donker et al. (1976) vonden een primaire autonome innervatie. Mc Guire (1986) toonde zowel een autonome als somatische innervatie aan en wolgens Gosling (1979, 1985) wordt de $m$. sphincter urethrae externus geïnnerveerd door somatomotorische vezels in de $n$. pelvicus.

De afferente zenuwen beginnen als vrije zenuwuiteinden, corpuscula lamellosa (Pacini) of andere ingekapselde receptoren, zoals de corpuscula genitalia (Krause) en de corpuscula tactus (Meissner), alle gelegen in de submucosa en tunica muscularis.

De afferente vezels van receptoren in de mucosa van de urethra bij de kat lopen via de $n$. pudendus. Zij zijn gemyeliniseerd en vooral opgebouwd uit kleine type III vezels en in mindere mate uit type 11 vezels (Martin et al., 1974). Over de verhouding van type lll vezels ten opzichte van type II vezels bij de mens is niets bekend. Spierspoelen zijn in de $\mathrm{m}$. sphincter urethrae externus niet gevonden, wel in de m. sphincter ani externus en de bekkenbodemmusculatuur.

\subsubsection{CENTRALE INNERVATIE}

\section{a. Centrale innervatie van blaas en urethra}

Viscerale en lumbales afferente vezels synapteren op interneuronen en projectieneuronen, gelocaliseerd aan de basis van de achterhoorn in de grijze stof. De afferente vezels van de $\mathrm{n}$. pelvicus projecteren in de tractus van Lissauer. Collateralen van deze tractus breiden zich naar lateraal uit in de oppervlakkige lagen van de achterhoorn (lamina I en II). Andere eindigen in de lamina $V$ en VI aan de basis van de achterhoorn in het gebied van de parasympathische nuclei ${ }_{\text {. }}$ Ook is er een uitbreiding naar mediaal. Deze collateralen eindigen in de commissura posterior.

De interneuronen nemen deel aan de spinale reflexen en de projectieneuronen dienen als schakelstation voor projectie van invloeden naar hogere centra. Het circuit voor de normale mictie wordt gerelayeerd door nuclei in het tegmentum pontis.

Afferente vezels van spanningsreceptoren van de blaas en receptoren in de mucosa van de urethra lopen respectievelijk via de $n$. pelvicus en de $n$. pudendus en schakelen in het sacrale merg over op secundaire sensibele neuronen. De vezels kruisen in de lumbosacrale segmenten de mediaanlijn en lopen verder in de tractus spinothalamicus in de zijstreng. Zij dienen voor het bewust worden van pijn, temperatuur van de urethra en blaasvulling (Nathan en Smith, 1951, 1956a en 1956b). Naarmate deze baan verder stijgt bevindt hij zich meer naar voren in de zijstreng. Kuru (1965) noemde deze baan de 'sacrobulbar tract.

Verder is er afferente input welke tot bewuste perceptie leidt, via vezels van de achterstreng, die direct rostraal van de nucleus gracilis synapteren en vandaar via de arcuatus internus en de lemniscus medialis naar de thalamus met als functie het overdragen van informatie omtrent blaaspositie, mictiegevoel, spanning van de urethra en de tonus in de bekkenbodemmusculatuur. Deze baan noemde Kuru (1965) de 'pelvic sensory vagus tract' (Fletcher en Bradley, 1978).

De descenderende banen zijn:

- de tractus reticulospinalis lateralis, die gelegen is in de zijstreng. De oorsprong is beiderzijds gelegen in het mesencephalon, de pons en de medulla oblongata. De banen kruisen in de lumbosacrale segmenten en faciliteren preganglionaire neuronen naar de detrusor en inhiberen de neuronen naar de gladde en dwarsgestreepte spieren van de 
urethra. De efferente neuronen worden bilateraal geactiveerd. Van de drie descenderende banen is deze de belangrijkste.

- De tractus reticulospinalis medialis, die in de pons begint en door de mediale voop. streng loopt. Deze inhibeert neuronen van de $\mathrm{m}$. sphincter urethrae externus.

- De tractus reticulospinalis anterioris, die in de voorstreng loopt en in de medulla oblongata begint inhibeert de detrusor neuronen en faciliteert de sphincter neuronen. De vezels wan deze baan vermengen zich met die van de tractus reticulospinalis lateralis in de onderste helft van het ruggemerg (Fletcher en Bradley, 1978).

De m. sphincter urethrae externus, de peri-urethrale musculatuur en de $\mathrm{m}$. sphincter anil externus zijn in de motorische cortex gerepresenteerd. De efferente neuronen uit de mo. torische cortex lopen via de pyramidebaan en eindigen via synapsen op de motorische neuronen in de nucleus pudendus in de sacrale segmenten $\mathrm{S} 2 \mathrm{t} / \mathrm{m} \mathrm{S4}$.

De corticale arealen in relatie tot de detrusorspier zijn gelocaliseerd in het bovenste mediale deel van de frontaalkwab, het genu van het corpus callosum en het voorste deel van de gyrus cinguli.

Subcorticale delen van de hersenen, die een relatie hebben tot de blaas, zijn: de nuclei van de thalamus, delen van de basale ganglia en het limbische systeem, de hypothalamus, het voorste gedeelte van vermis cerebelli en de nucleus fastigii, en de formatio reticularis over haar gehele lengte (Bradley, 1978).

\section{b. Centrale innervatie van genitaliën}

De centra die bil de erectie een rol spelen, werden bij apen onderzocht door MacLean en Ploog (1962). Naar hun mening hebben zowel corticale als subcorticale structuren hierbij een functie. De subcorticale structuren zijn de nucleus paraventricularis hypothalami, gedeelten van de 'medial forebrain bundle', delen van het limbische systeem (corpus mamillare, gyrus cingull, bundel van Vicq d'Azyr, hippocampus), septale kernen en substantia nigra. De corticale structuur die een functie heeft bij de erectie is de gyrus rectus.

De centra die bij de ejaculatie een rol spelen zijn: de 'medial forebrain bundle' met de area preoptica. Ook de tractus spinothalamicus en delen van de thalamus staan ten dienste van de emissie (eerste deel ejaculatie). De gyrus rectus en septum pellucidum zijn neurale structuren, die de sexuele functie in verband brengen met de reuk. Bij veel zoogdieren staan reukstimuli in verband met het sexueel gedrag.

Het corpus mamillare, de nucleus dorsomedialis thallami en de gyrus cinguli brengen de sexuele functies in verband met visuele stimuli. De descenderende baan loopt via de substantia nigra en het ventrolaterale deel van de pons.

\subsection{ADRENERGE EN CHOLINERGE RECEPTOREN IN DE URINEWEGEN EN GENITALIEN}

Ahlqvist (1948) postuleerde op grond van onderzoek naar het effect van verschillende stoffen met een adrenerge werking, een hypothese waardoor de dualistische werking van adrenaline (exciterend en inhiberend) kon worden verklaard. Volgens deze hypothese zouden er twee verschillendle soorten receptormoleculen bestaan (alfa- en betareceptoren). De alfareceptoren bleken in het algemeen exciterend te zijn en te leiden tot contractie van de gladde musculatuur. De betareceptoren bleken in het algemeen inhiberend te zijn en te leiden tot relaxatie. De aanwezigheid van alfa- en betareceptoren is vervolgens herhaaldelijk beschreven, zowel in dierexperimenten als bij de mens (Edvardsen en Setekleiv, 1968; Nergardh en Boreus, 1972).

Aangetoond is dat bij de mens in alle delen van de blaas beide receptortypen aanwezig zijn, met een opmerkelijke voorkeur voor de betareceptoren in de apex en voor alfareceptoren in de fundus en blaashalls. In de urethra zijn zowel alfa- als betareceptoren aangetoond, vooral in het achterste deel. Waarschijnlijk zijn er ook alfa- en in veel mindere 
mate betareceptoren gelegen in het gebied van de dwarsgestreepte urethramusculatuur. De gladde musculatuur van de prostaat toont een rijke adrenerge innervatie en heeft een uitgesprokern alfareceptoractiviteit (Herrlinger en Schrott, 1978; Scultety, 1980).

Cholinerge receptoren (alle receptoren die met acetylcholine reageren) worden in een gelikmatige verdeling in de gehele blaas en urethra gevonden. Tevens vindt men deze receptoren in het genitale buizensysteem. Voor een model om de verdeling van de adrenerge en cholinerge receptoren van de blaas aanschouwelijk te maken zie figuur 2.2 .

Na parasympathische denervatie treedt een verandering op in de adrenerge innervatie van de tunica muscularis, namelijk in die zin, dat de betareceptoractiviteit (relaxatie) via stimulatie van de $n$. hypogastricus verandert in een alfareceptoractiviteit (contractie) (Sundin et al., 1977).

Het genitale buizensysteem heeft overwegend alfareceptoren en deze worden bij de emissie geactiveerd. De bloedvaten, die een functie hebben bij de erectie, hebben zowel alfa- als betareceptoren met een overheersing van de alfareceptoren.

m. sphincter urethrae externus

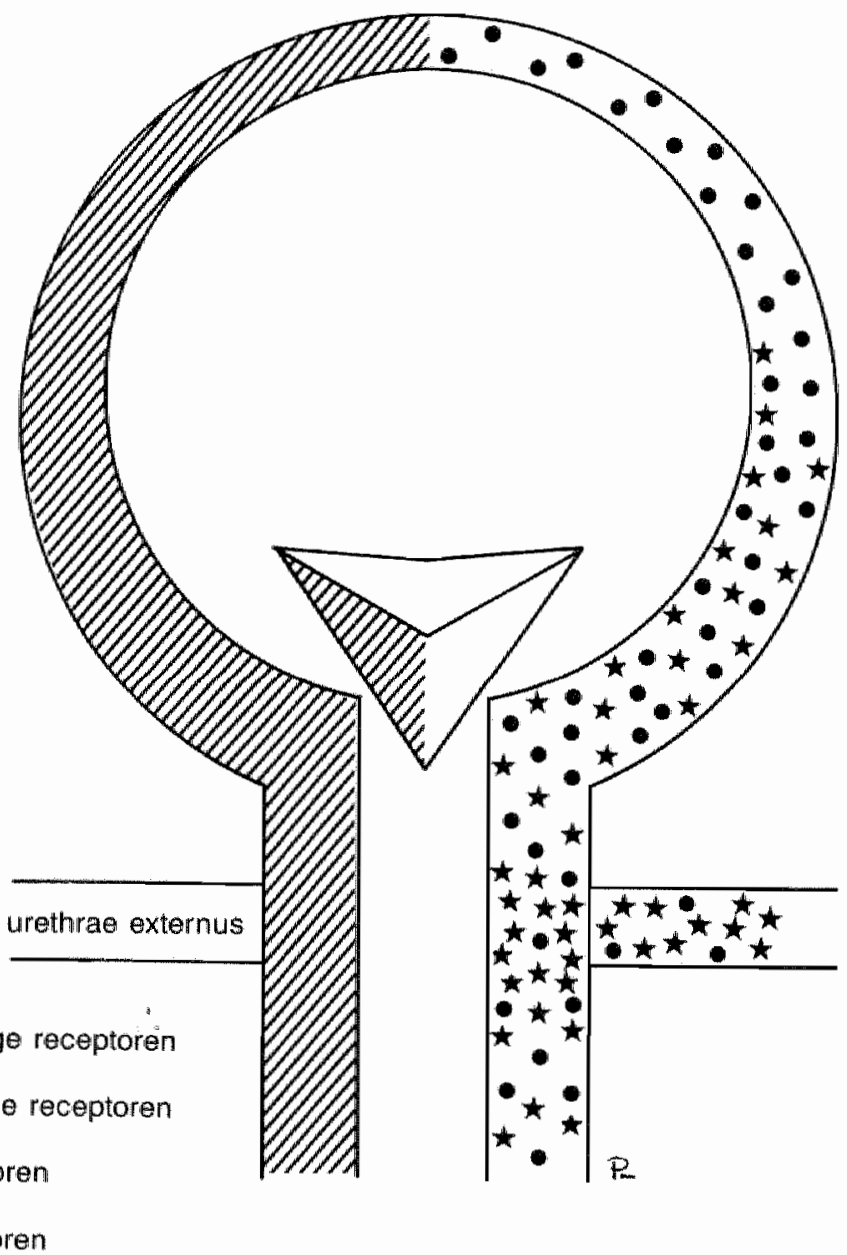

$\beta$-receptoren

Figuur 2.2

Verdeling van adrenerge en cholinerge receptoren van de blaaswand en blaashals 
De innervatie van de blaas bestaat uit een synaptische interactie van het centrale en perifere zenuwstelsel op alle niveaus. Deze interactie regelt de opslag van de urine en de lediging van de blaas. Neuro-anatomisch zijn voor deze interactie centrale en perifere delen van het zenuwstelsel verantwoordelijk welke met elkaar in verbinding staan.

\section{GANGLIA VAN DE PLEXUS PELVICUS}

De plexus pelvicus heeft twee soorten ganglia: de sympathische (adrenerg), de parasym pathische (cholinerg) en de gemengde. Preganglionaire sympathische zenuwvezels synapteren in deze ganglia met de dendrieten of het soma van de postganglionaire neuronen. De transmitter is hier acetylcholine. De preganglionaire parasympathische zenuwvezels eindigen voornamelijk op de dendrieten van de postganglionaire neuromen. Ook hier is de transmitter acetylcoline. Deze cholinerge mechanismen kunnen door adrenerge, purinerge en enkephalinerge systemen gemoduleerd worden (DeGroat en Booth, 1980). Neurofysiologisch gezien hebben deze ganglia de functie van het versterken van de duur en amplitudo van stimuli uit het ruggemerg (Bradley, 1976).

Elektroffysiologisch is aangetoond, dat sympathische postganglionaire vezels via door Hamberger en Norberg (1965) en Khanna et al. (1975) beschreven interneuronen, parasympathische transmissie in de ganglia kunnen inhiberen. Deze bevinding geeft steun aan de hypothese dat parasympathische en sympathische stimulli worden geintegreerd op ganglionair niveau ten behoeve van het reguleren van de blaasfunctie (Bradley en Teague, 1968).

\section{DE AFFERENTIE UIT DE BLAAS}

Detrusorreceptoren worden door toename van de blaaswandspanning (dilatatie enlof contractie) tot ontlading gebracht. Deze ontladingsfrequentie blijft vrij constant, ook bij verdere toename van de blaasdruk. Omdat de hoogte van de individuele prikkeldrempel van de receptoren verschillend is, kan het afferente systeem door recrutering van verschillende receptoren informatie over de variërende druk van de blaaswand overbrengen. De receptoren die impulsen afgeven aan sacrale afferenten ontladen zich niet als de blaas leeg is, doch wel reeds bij een geringe vullingstoestand. Wordt een vullingstoestand overschreden die het $2 / 3$ deel van de mictiedrempel bedraagt dan treedt een reflex op die leidt tot een inhibitie van de wandspanning wia efferenten van de $\mathrm{n}$. hypogastricus (Langworthy et al., 1934). Daardoor kan de blaas zich verder vullen zonder dat mictie optreedt. Sacrale afferenten vervoeren dus vooral informatie uit de rekreceptoren en dienen tevens voor de geleiding van tast- en pijnsensaties van de mucasa van de blaas en het blaaswullingsgevoel.

Plum en Colfeld (1960) vestigden de aandacht op het feit dat ritmische blaascontracties een mictiereflex kunnen induceren. Deze ritmische contracties treden op blj een vulling van meer dan 1/3 van de mictiedrempel. Zij hebben aanvankelijk een lagle amplitudo die toeneemt naarmate het volume groter wordt. Zij zijn myogeen van aard en ontstaan bij rek van de spiervezels. Plum en Colfeld (1960) correleerden hieraan het ontstaan van de mictiedrang.

De receptoren die impulsen geleiden via vesicale lumbale afferenten worden slechts geprikkeld door een grote uitzetting van de blaas (Talaat, 1937). Doorsnijding van deze afferenten bij de kat op het niveau van de achterwortel heeft geen invloed op de opslag en lozing van urine (Edvardsen, 1968). Zij zorgen voor de geleiding van tast-, rek- en pijnsensaties van de mucosa van de blaashals. De bewustwording van temperatuur wordt waarschijnlijk niet bepaald door afferente vezels van de blaas doch door stimulatie van receptoren in de urethra (Bradley et al., 1975). Hieruit volgt dat bij de normale mictiedrang vooral sacrale afferenten betrokken zijn en het gevoel van urinepassage geleid wordt via de somatische afferenten in de $n$. pudendus (Wijndaele en De Sij, 1980). 


\section{DE EFFERENTIE NAAR DE BLAAS}

De detrusorspier wordt geinnerveerd door postganglionaire neuronen. De efferente eindlakken zijn op een aantal plaatsen met wisselende tussenruimten verwijd (synapsknopjes). Op deze plaatsen is geen protoplasma van cellen van Schwann aanwezig. ledere synapsknop innerveert een aantal gladde spiercellen. De spiercellen kunnen dichtbij, maar ook op aanzienlijke afstand van de synapsknopjes gelegen zijn, afhankelijk van de mate van de rekking van de blaas. In deze synapsknopjes bevinden zich blaasjes met Iransmitter. Onder invloed van een actiepotentiaal diffunderen transmittermoleculen achtereenvolgens door de axonmembraan en de basaalmembraan die de cel van Schwann omgeeft. Vervolgens gaan ze door de extracellulaire ruimte en door de basaalmembraan, die de gladde splercel omgeeft. Tenslotte komen ze in contact met de spiercelmembraan. Het resultaat is een depolarisatie van de receptoren van sleutel- of pacemakercellen van het gladde spierweetsel. Deze pacemakercellen liggen verspreid door de detrusor- en urethramusculatuur.

Het morfologisch bewezen nauwe contact tussen de aangrenzende gladde spiercellen (nexus-verbindingen) doet de mogelijkheid vermoeden van directe overbrenging van een ionenstroom (Fletcher et al., 1969). De enige fysiologische aanwijzing voor het bestaan van zo'n ephaptische koppeling tussen spiercellen van de blaas is het voorkomen van spontane ritmische blaascontracties in de geïsoleerde blaasspier (Anderson ett al ", 1972).

\section{STIMULATIE- EN DOORSNIJDINGSPROEVEN}

Elektrische stimulatie van een $\mathrm{n}$. hypogastricus bij de mens (Learmonth, 1931) geeft de volgende verschijnselen:

- een vernauwing van de ipsilaterale ureteropening en van het trigonum vesicae

- een contractie van de $\mathrm{m}$. sphincter trigonalis

- een contractie van de gladde spieren van de prostaat, vesiculae seminales en ductus ejaculatorius

- een contractie van bloedvaten van blaas en blaashals, maar vooral in het trigonum vesicae

- een normaall blijven van de detrusorspier.

Bij doorsnijding van de $\mathrm{nn}$. hypogastrici bij de mens ontstaan de volgende verschijnselen:

- een lichte verwijding van de ureteropeningen

- een vergroting van het trigonum

- een verwijding van bloedvaten van blaas en blaashals

- het gesiloten blijven van de blaashals

- een niet meer plaatsvinden van de ejaculatie

- een normaal blijven van de blaasfunctie.

Laatstgenoemde waarnemingen komen gedeeltelijk overeen met bevindingen bij dierproeven. Uit deze gegevens kan geconcludeerd worden, dat de motorische vezels van de $n$. hypogastricus zowel het trigonum vesicae innerveren als de organen, die verantwoordelijk zijn voor de emissie van het semen.

De blaashals wordt gesloten door stimulatie van de sympathische vezels, maar wordt geopend door contractie van de detrusor gedurende de mictie (Lapides et al., 1960) en door een reflexmatig geinduceerde relaxatie van de dwarsgestreepte spieren van de bekkenbodem en het perineum.

Nordling et al. (1982) achten het meest waarschijnlijk, dat een normale parasympathische innervatie noodzakelijk is om de blaashals in rust gesloten te houden. Als hypothese stelden zij dat of een normale parasympathische innervatie noodzakelijk is om de blaashals te sluiten, óf dat een normale parasympatische innervatie noodzakelijk is om decompensatie van de blaashals te voorkomen, indien een infravesicale obstructie aanwezig is. Het feit dat een open blaashals in rust nauwelijks voorkomt bij vrouwen met een areflexie van de blaas, zoals uit hun onderzoek blijkt, pleit voor deze laatste hypothese.

De $n$. hypogastricus is voornamelijk verantwoordelijk voor de opslag van de urine. Elektri- 
sche stimulatie van de $\mathrm{nn}$. pelvici bij dieren veroorzaakt een krachtige blaascontractie. Door deze contractie verwijdt de blaashals zich en wordt zo tot een deel van de bllaaswand.

Habib (1963) toonde bij honden aan, dat na stimulatie van de perifere stomp na doorsnijding van de voorwortel van S3 of S4, een contractie van de gehele ipsilaterale blaashelft optreedt.

Na doorsnijding van de $\mathrm{n}$. pelvicus vindt geen contractie plaats van de blaas en dus ook geen mictie (Elliot, 1907).

Uit het bovenstaande blijkt, dat parasympathische innervatie (n. pelvicus) voor de motoriek wan de blaas het belangrijkst is.

De gevoelsmodaliteiten van de urethra, die leiden tot bewustwording, zijn rekking van de wand, tast, passagegevoel, pijn- en temperatuur.

Bij het handhaven van de continentie speelt de urethra een rol door middel van de volgende mechanismen (Bradley, 1978):

- een passieve weerstand voor urine bij lage drukniveaus door de elastische vezels

- een hydrostatische weerstand door de rijke vascularisatie van de submucosa

- een tonische contractie van de $\mathrm{m}$. sphincter urethrae internus bij toename van intravesicale druk

- het opvangen van verhoogde intravesicale druk door de m. sphincter urethrae externus, ondersteund door de $\mathrm{m}$. pubacoccygeus.

\section{CENTRALE BEINVLOEDING VAN DE MICTIE}

Zoals reeds eerder beschreven zijn de subcorticale delen van de hersenen die een relatie hebben tot de blaas de volgende (Bradley, 1978):

1. de formatio reticularis over haar gehele lengte

2. thalamuskernen

3. delen van de basale ganglia en limbische systeem

4. de hypothalamus

5. het voorste gedeelte van vermis cerebelli en de nucleus fastigii.

Ad 1: de formatio reticularis over haar gehele lengte

Barrington (1921) toonde bij katten aan, dat na een doorsnijding van het mesencephalon nog een contractie van de blaas na blaaswulling bleef optreden. Deze verdween echter na doorsnijding van het onderste deel van de hersenstam of het ruggemerg. Hij localiseerde een reflexcentrum voor het beginnen en continueren van de mictie in het dorsolaterale deel van de formatio reticularis in het voorste deel van de pons (centrum van Barrington). Hij wond ascenderende en descenderende verbindingen van dit centrum met het sacrale merg in het achterste gedeelte van de zijstrengen.

Kuru (1965) vond centra die blaascontractie en relaxatie veroorzaken in de hersenstam. Hij noemde deze centra respectievelijk 'bulbar vesicoconstrictor centre' en 'bulbar vesicorelaxer centre'. Deze centra zijn dicht bij elkaar gelegen en met elkaar verbonden, maar ook met de cerebrale structuren en spinale kernen, die de mictie verzorgen.

Tang en Ruch (1955) onderzochten de faciliterende en inhiberende invloeden op de sacralle mictiereflex bij katten door middel van doorsnijding op verschillende niveaus in het centrale zenuwstelsel. Zij vonden faciliterende centra in het voorste deel van de pons en in het achterste deel van de hypothalamus en inhiberende centra in het mesencephalon en de frontaalkwab.

In de formatio reticularis van de gehele hersenstam zijn mictiecentra gelocaliseerd. Hier ontstaan zenuwvezels, die descenderen in de reticulospinale banen en synapteren op detrusor en sphincter efferente neuronen in het sacrale ruggemerg. Via deze vezels kan beinvloeding vanuit corticaal en subcorticaal plaatsvinden. Tevens komen in deze centra afferente prikkels samen. 


\section{Ad 2: thalamuskernen}

Ascenderende vezels, die geactiveerd worden door receptoren van de blaas en urethra synapteren op neuronen in de ventrolaterale thallamuskernen. Deze kernen thebben reciproke verbindingen mel de hersenschors, de basale ganglia en het cerebellum.

De elektro-encephalogratische veranderingen, die optreden bij vulling van de blaas, worden via dit systeem tot stand gebracht (Bradley. 1980).

\section{Ad 3: delen van de basale ganglia en limbische systeem}

De basale ganglia beïnvloeden detrusorcontracties. Ablatie resulteert in een hyperreflexie van de detrusor. Informatie naar sommige delen van de basale ganglia komt uit de thalamus en de pyramidecellen van de frontaalkwab waar de blaas en urethra gerepresenteerd zilin. Informatie uit de basale ganglia gaat naar de mictiecentra in de hersenstam. Het limbische systeem beilnvloedt het autonome zenuwstelsel via de hypothalamus en de formatio reticularis. Verwijdering van de lobus temporalis beiderzijds, inclusief delen van het limbische systeem als hippocampus en amygdala, leidt echter niet tot een mictiestoornis bij de mens.

\section{Ad 4: de hypothalamus}

In het voorste deel van de hypothalamus bevinden zich neuronen met een detrusor motorische functie. Tevens zijn er kernen in het achterste deel van de hypothalamus aangetoond, die tot ontlading worden gebracht door een volle blaas (Stuart et al., 1964).

\section{Ad' 5: het voorste gedeelte van vermis cerebelli en de nucleus fastigii}

Het cerebellum ontvangt informatie uit de detrusor en bekkenbodemmusculatuur via spinocerebellaire banen. Deze eindigen voornamelijk in het voorste deel van de vermis. Purkinjecellen in de cerebellaire cortex synapteren op neuronen in de nucleus fastigii, en beinvloeden detrusorcentra in de formatio reticularis. De cerebellaire informatie omtrent de bekkenbodemmusculatuur loopt via de pedunculus cerebelli superior en synapteert in de ventrolaterale thalamuskern, die op zijn beurt projecteert op de motorische cortex, ter plaatse van de urethra. Tevens regelt het cerebellum het effect van motorische impulsen, die ontstaan in andere delen van de cortex cerebri.

\section{DE MICTIEREFLEXEN}

Uit proeven van DeGroat (1975) bij katten met een intact zenuwstelsel blijkt dat bij blaasdilatatie de preganglionaire parasympathische neuronen, waarvan de cellichamen in het sacrale deel van het ruggemerg zijn gelegen, in toenemende mate gaan vuren. Met andere woorden, een circuit voor het ontstaan van een blaascontractie, opgewekt door uitzetling wan de blaas, is gelegen in het sacrale deel van het ruggemerg met zijn perifere afferente en efferente verbindingen.

Het concept van een supraspinaal reflexcentrum werd opgesteld door Barrington (1914) en later gemodificeerd door DeGroat (1975). Barrington (1914) en Kuru (1965) beschreven bil katten zeven afzonderlijke opeenvolgende reflexen "die de coördinatie van de detrusorcontractie en urethrale relaxatie beschrijven en bijdragen tot een effectieve mictie (tabel 2.1).

Bradley en Teague (1972) toonden bij de kat aan dat de tweede reflex zowel segmentaal verloopt als via een lange route naar de hersenstam.

Later bleek dat bij de mens niet al deze zeven reflexen voorkomen. Met name de vierde (Hofman, 1969) en de zevende reflex (Nathan, 1952) konden niet worden aangetoond. De derde reflex heeft geen relatie tot de mictie (Hofman, 1969) en de zesde reflex is mogelijk niet van belang, omdat de opening van de blaashals een passief mechanisme is (Lapides et al, 1957 en 1960). Wat betreft de vijfde reflex achite Hofman (1969) het waarschijnlijk dat niet de blaasuitzetting, doch de blaascontractie de stimulus is voor relaxatie van de bekkenbodemmusculatuur, omdat de blaascontractie voorafgaat aan de relaxatie van de dwarsgestreepte bekkenbodemmusculatuur. 
Mictiereflexen beschreven door Barrington (1914) en Kuru (1965)

effect en oorzakelijke prikkel

1. Krachtige blaascontractie ten gevolge van blaasuitzetting.

2. Krachtige blaascontractie opgewekt door het stromen van vloeistof door de urethra.

3. Voorbijgaande zwakke blaascontractie als gevolg van uitzetting van het proximale deel van de urethra.

4. Relaxatie van de urethra als gevolg van vloeistofdoorstroming.

5. Relaxatie vain de $m$. sphincter urethrae externus opgewekt door blaasuitzetting.

6. Relaxatie van de gladde spier van het proximale deel van de urethra als gevolg van blaasuitzetting.

7. Voorbijgaande zwakke blaascontractie opgewekt door het stromen van vloeistof door de urethra. afferentie

n. pelvicus

n. pudendus

n. hypogastricus

n. pudendus

n. pelvicus

n. pelvicus

ก. pelvicus centraal

Supraspinaal

supraspinaal

spinaal

n. hypogastricus

n. pelvicus

n. pudendus

spinaal

spinaal

m. pudendus efferentie

ก. pelvicus

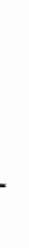


Bij een suprasacrale ruggemergstaesie werandert de mictiereflex van een "long loop" reflex in een segmentale reflex. Of deze segmentale reflex bili de mens van nature aanwezig is of ontstaat door "collateral sprouting" is miet bekend (Andersen, 1976; Liu en Chambers, 1985). Bif een suprasacrale ruggemergslaesie ontstaat een nieuw mictiecentrum in het sacrale deel van het ruggemerg. Omdat de drempel tot ontladen als gevolg van het ontbreken van supranucleaire remming verlaagd is, ontstaan reeds bij lage blaasvolumes onvrifwillige detrusorcontracties (detrusorhyperreflexie). Deze onvrijwillige detrusorcontracties kunnen alleen ontstaan als de sacrale reflexboog intact is.

Recurrente inhibitie van de activiteit van de preganglionaire parasympathische vezels in de n. peivicus werd op eenzelfde wijze door Bradley (1969) aangetoond als beschreven bij de motorische voorhoorncel door Renshaw (1941). Renshaw beschreef dunne collateralen, die de axonen van de motorische voorhoorncellen onmiddellijk na hun oorsprong verlaten en teruglopen naar kleine schakelcellen in de voorhoorn. Excitatie van de motorneuronen doet de inhibitie toenemen.

De relaxatie van de dwarsgestreepte musculatuur gedurende de mictie kan gemakkelijk onderbroken worden door nociceptieve prikkels, bijvoorbeeld toegediend aan de voetzool. Bij de flexiereflex gaat contractie van de buigmusculatuur gepaard met een relaxatie van de strekmusculatuur. Bors en Blinn (1956) suggereerden een overeenkomstige relatie tussen de dwarsgestreepte musculatuur van de bekkenbodem en de detrusor, met andere woorden een contractie van de bekkenbodem zou relaxatie van de detrusor vercorzaken. De afferenten van deze reflex verlopen in de $\mathrm{n}$. pudendus en zijn afkomstig uit de dwarsgestreepte musculatuur. Deze inhiberen efferente vezels, die in de n. pelvicus verlopen. Blaascontractie kan geïnhibeerd worden door willekeurige contractie van de bekkenbodemmusculatuur. Tevens kan een blaascontractie geinhibeerd worden door anale stimulatie (Pompeius, 1966), via een spinaal circuit met afferentie uit de $n$. pudendus en efferentie via de vezels in de $n$. pelvicus.

De twee hoofdfuncties van de blaas zijn opslag en lozing van urine. De opslag wordt geregeld via de $n$. pelvicus en de $n$. hypogastricus. De afferente vezels, die hierbij een rol spelen, lopen in de $n$. pelvicus en de efferente vezels in de $n$. hypogastricus. Het resultaat is een inhibitie van de detrusor en facilitatie van de $\mathrm{m}$. sphincter urethrae internus. $\mathrm{De}$ inhibitie is een indirect effect via de parasympathische ganglia. De lozing wordt bewerkstelligd door afferente en efferente vezels in de $n$. pelvicus en geschiedt via een reflex verlopend over de mictiecentra in de hersenstam. Er treedt een contractie van de blaaswand en een relaxatie van de blaasuitgang op. Dit laatste door inhibitie van de $\mathrm{dwarsgestreepte} \mathrm{bekkenbodemmusculatuur.}$

Bradley (1978) beschreef een concept voor de organisatie van de normale mictiereflex bij de mens. Hij gaat ook uit van een primair mictiecentrum boven het sacrale merg gellegen in de pontiene en mesencephale formatio reticularis. Hij neemt het bestaan aan van vier afzonderlijke circuits (loops), die weliswaar afzonderlijke functies hebben, maar onderling zo geîntegreerd zijn dat een effectieve opslag en lozing van de blaasinhoud mogelijk is. Loop I bestaat uit reciproke verbindingen van de frontale schors met de formatio reticularis in de hersenstam. De frontale neuronen zijn gelocaliseerd in het anteromediale deel van de frontaalkwab tot de sulcus centralis Rolandi. De motorische cellen zijn gelegen in laag 5 van de cerebrale cortex en bestaan uit een cellichaam, een axon en dendrieten. De dendrieten strekken zich uit tot laag 1 en ontvangen via een synaps input uit de sensorische vezels. De axonen van de motorische cellen verlopen naar de formatio reticularis in de hersenstam. De frontale schors heeft een inhiberende invloed op de formatio raticularis. Bij beschadiging van deze verbindingen ontstaat een detrusorhyperreflexie. Andere structuren die een regulerend effect op deze formatio reticularis hebben, zijn de kernen van de thalamus, basale ganglia, hypothalamus, cerebellum en limbische systeem.

Loop II heeft een perifere en een spinale component. De perifere component bestaat uit proprioceptieve axonen met vertakkingen in de detrusorspier. Sensibele impulsen worden geleid via afferente axonen in de $n$. pelvicus naar het sacrale merg. Vandaar stijgen zij op in de achterstreng tot de detrusorcentra in de hersenstam. Volgens Bradley (1978) 
synapteren deze afferente axonen niet met motorische neuronen wan de detrusor in het sacrale deel van het ruggemerg.

De descenderende motorische vezels uit de detrusorcentra in de hersenstam vormen synapsen met de parasympathische motorische neuronen van de detrusor in de intermediolaterale celkolom van de segmenten S2, S3 en S4. Van hier verlopen axonen naar de detrusorspier. De output uit de detrusornucleus is gereguleerd middels een terugkoppeling. Deze is belangrijk voor het beëindigen van de mictiereflex en om neuronen met sexuele en defaecatie functie in de omgeving van de motorische neuronen van de detrusor te remmen.

Loop III heeft alleen een perifere component en bestaat uit proprioceptieve axonen met vertakkingen in de detrusorspier. Sensibele impulsen worden geleid via afferente axonen in de $\mathrm{n}$. pelvicus. Deze axonen synapteren op motorische neuronen in de voorhoorn van de segmenten $\mathrm{S} 2 \mathrm{t} / \mathrm{m}$ S4. Van hieruit verlopen motorische vezels van de $\mathrm{n}$. pudendus naar de peri-urethrale musculatuur (bekkenbodem). Tijdens de vulling van de blaas zendt de nucleus pudendus voortdurend motorische impulsen uit om een tonische contractie in de bekkenbodemmuscullatuur te handhaven. Bij een voldoende aantal impulsen uit de detrusorspier, zoals die optreden bij blaascontractie, treedt een inhibitie op van de tonische activiteit uit de nucleus pudendus. Hiervan is een relaxatie van de bekkenbodemmuscullatuur het gewolg (Bradley, 1978).

Loop IV bestaat uit een segmentaal en suprasegmentaal gedeelte. Het segmentale gedeelte bestaat uit sensibele en motorische axonen in de $n$. pudendus. De afferente impulsen verlopen via de $\mathrm{n}$. pudendus naar het sacrale merg en vandaar via het achterstreng/lemniscus systeem naar thalamus, gyrus postcentralis en cerebellum. De efferente impulsen uit laag 5 van de motorische cortex lopen via de pyramidebaan en eindigen via synapsen op de motorische neuronen in de nucleus pudendus in de sacrale segmenten S2 t/m S4، Deze loop IV verkrijgt zijn impulsen uit spierspoelen in de bekkenbademmusculatuur en in de $\mathrm{m}$. sphincter ani externus. Hierdoor is een bewuste controle mogelijk van de dwarsgestreepte spieren van de externe sphincter en bekkenbodemmusculatuur.

Volgens Bradley verlopen de reflexen, die dienen om die mictie op gang te brengen, via loop I en II. De reflexen, die dienen om de mictie in stand te houden, lopen via loop II en III en tevens middels een terugkoppeling via de urethrovesicale reflexen. De afferentie van deze laatste reflex zou verlopen via de $n$. pudendus, afkomstig zijn uit de urethra en gestimuleerd worden door rekreceptoren. De efferentie zou verlopen in de $\mathrm{n}$. pelvicus. Dit is analoog aan de reflex die optreedt na stimulatie van cle receptoren in de urethra en die de blaascontractie faciliteert.

De reflexen, die dienen om de mictie te beëindigen, lopen via loop I en IV en middels een negatieve terugkoppeling op de motorische neuronen van de $\mathrm{n}$. pelvicus (recurrente inhibitie).

Voor een overzicht van deze gegevens zie figuur 2.3. 


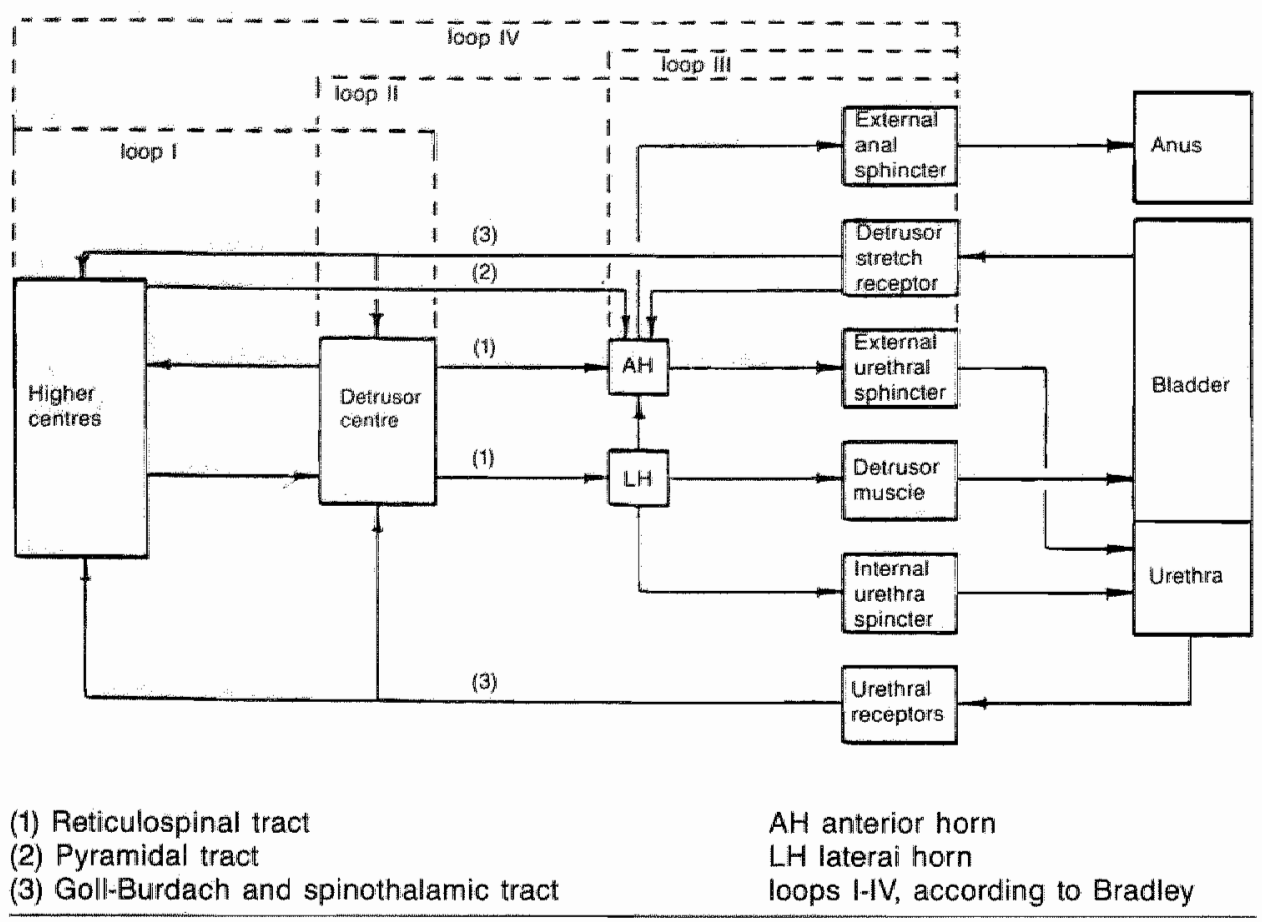

Figuur 2.3.

Blokdiagram van de fysiologische interacties in het urogenitale systeem

\subsection{FYSIOLOGIE VAN HET SEXUEEL FUNTIONEREN}

\section{ERECTIE}

Door experimenteel onderzoek (zenuwstimulatie) en toepassing van gladde spierrelaxantia zijn 2 fasen in de erectie te onderscheiden (Lue en Tanagho, 1987; Fournier et al., 1987).

1. De vasculaire erectiefase met 3 haemodynamische veranderingen:

a. actieve dilatatie van aanvoerende arteriën en arteriolen na relaxatie van de gladde musculatuur

b. toename van de intracaverneuze druk na relaxatie van de gladde musculatuur wan de sinusoidale ruimten

c. deels actieve en deels passieve veneuze constrictie.

Dit laatste vindt mogelijk plaats door compressie van de subalbugineale veneuze plexus tegen de tunica albuginea.

2. De musculaire erectiefase. Door contractie van de $\mathrm{mm}$. ischio- en bulbocavernosi, na stimulatie van de $\mathrm{n}$. pudendus, worden de proximale corpora cavernosa gecomprimeerd on treedt een complete rigiditeit met verdere intracaverneuze drukstijging op.

Buez et al. (1957) concludeerden op grond van de gevolgen van sympathectomieën bij 44 patienten, dat resectie onder het ganglion $L 1$ geen en resectie vanaf $L 1$ craniaalwaarts well gevolgen heeft voor het tot stand komen van erecties.

Op grond van bevindingen bij ruggemergslaesies ter hoogte van en boven het sacralle merg concludeerden Bors en Comarr (1960) en Comarr (1970), dat er bij de man een psychogeen activeerbaar erectiecentrum aanwezig is ter hoogte van de overgang van het thoracale naar het lumbale merg. Vanuit dit centrum treden vezels via de wortels Th11 $t / \mathrm{m}$ L2 en verlopen dan via de grensstreng, welke zij voornamelijk via het ganglion L1 verlaten, met de $\mathrm{nn}$. splanchnici naar de sympathische plexus pelvicus en vandaar naar de 
penis (Tarabullcy, 1972; Verkuyl, 1976). Volgens Verkuyl (1976) gaat het om cholinerge vezels. Zij zouden bij het tot stand komen van de erectie een rol spelen door middel van het verminderen van de normaal aanwezige vasoconstrictie.

Erecties kunnen ook opgewekt worden door stimulatie van de glans penis. Somatisch at. ferente impulsen worden dan via de $n$. dorsalis pen is (tak van $n$. pudendus) naar de sacrale ruggemergssegmenten $\mathrm{S}_{2}, \mathrm{~S} 3$ en $\mathrm{S} 4$ geleid. Hier worden impulsen geinduceerd welke via de nervus en plexus pelvicus de penis bereiken.

Het is ook mogelijk dat viscerale sensaties, die via afferente vezels in de $n$. pelvicus naar het sacrale merg geleid worden, hierbij een rol spelen (Verkuyl, 1976). Op deze wijze zouden spontane erecties kunnen optreden, waaraan geen psychogene of tactiele prikkels voorafgaan.

Bij vrouwen treden ongeveer dezelfde processen op (erectie van de clitoris, zwelling van de labia minora en lubricatie van de schede) die ook op vaatstuwing berusten. Hoewel de zenuwvoorziening bij vrouwen minder is onderzocht zijn er geen redenen om aan te nemen dat die anders verloopt dan bij mannen.

\section{EJACULATIE}

Bij de ejaculatie worden twee op elkaar volgende fasen onderscheiden: de emissie en de expulsie.

De emissie komt als volgt tot stand: via sympathicusprikkeling treden zowel krachtige contracties op in de vesiculae seminales en ductus ejaculatorius, als in het caput epididymidis en het vas deferens (Semans en Langworthy, 1938). Door deze contracties komen spermatozoën en zaadpllasma in de pars prostatica van de urethra.

Prikkeling van de innerverende sympathische zenuwvezels, met name de n. hypogastricus, is nodig om gladde spieractiviteit in het gehele genitale buizensysteem op te wekken en het transport van het zaad te regelen.

De ductus deferens is rijk aan sympathische zenuwvezels. Zowel histochemisch als met behulp van fluorescentie werden adrenerge zenuwen aangetoond. De concentratie noradrenaline is voorall hoog op plaatsen met veel spiercellen (Sjöstrand, 1965). In vitro zijn reeds met geringe concentraties noradrenaline contracties op te wekken in delen van het vas deferens (Ventura, 1973).

Naast een overheersende adrenerge stimulatie van de gladde spieren van het vas deferens en de vesiculae seminales is er ook een geringe cholinerge stimulatie bij de mens (Ventura, 1973). Een specifiek inhiberende innervatie van het vas deferens is niet aangetoand (Bell, 1972). Een remmende stof, met name prostaglandine, werd wel gevonden (Swedin, 1971). De secretie van het zaadplasma uit de vesiculae seminales wordt voornamelijk cholinergisch geïnnerveerd (Swaab, 1977).

De expulsie vindt plaats door stimulatie van de $n$. pudendus (Semans en Langworthy, 1938), die resulteert in contracties van de $\mathrm{mm}$. bulbo- en ischiocavernosi, waardoor de inhoud van de ampulla urethrae naar de meatus gepompt wordt waarna expulsie plaatsvindt.

Tijdens de emissie en de expulsie contraheert de $\mathrm{m}$. sphincter urethrae internus onder invloed van sympathische activiteit, zodat retrograde ejaculatie voorkomen wordt.

Voor het optreden van de ejaculatie zijn twee ruggemergscentra van belang (Bors en Comarr, 1960; Comarr, 1970; Verkuyl, 1976). Eén centrum is gelegen ter hoogte van de segmenten Th11 tot L2. Daar ontspringen de sympathische vezels, welke bij de emissie en het sluiten van de $\mathrm{m}$. sphincter urethrae internus tijdens de emissie betrokken zijn. Het tweede centrum is gelegen in het sacrale merg in de segmenten $\mathrm{S} 2 \mathrm{t} / \mathrm{m} \mathrm{S4}$. Deze centra staan met elkaar en met hersencentra in verbinding. Ten gevolge van de druk op de wand van de ampulla urethrae door het zaad, bereiken afferente impulsen via de $n$. pudendus en de $n$. pelvicus het sacrale merg (Retief, 1950). Deze impulsen geven aanleiding tot efferente stimuli welke via de $n$. pudendus contractie van de bekkenbodem induceren met als gevolg een expulsie. 


\section{ORGASME}

De orgastische ontlading bestaat zowel bij wrouwen als bij mannen uit een serie ritmische spiercontracties. Hoewel ejaculatie en orgasme niet onafscheidelijk met elkaar zijn verbonden gaat bij mannen het orgasme meestal gepaard met een antegrade ejaculatie. Bij vrouwen treden ritmische contracties op van de spieren rondom de schede-opening " die van de bekkenbodem en van de uterus.

Gunterberg en Pettersen (1976) vermeldden dat bij patienten bij wie in verband met tumorresectie in het kleine bekken sacrale wortels verwijderd werden, het orgasme in intensiteit verminderde. Zij kenden bil de beleving van het orgasme een rol toe aan de perceptie van sensaties veroorzaakt door contracties van zowel glad spierweefsel als van de bekkenbodemspieren. De eerste bereikt het ruggemerg via de n. hypogastricus en de tweede via de n. pudendus.

\subsection{FARMACOLOGIE}

Medicamenten die het urogenitale apparaat beïnvloeden kunnen als volgt worden ingedeeld:

1. farmaca met een adrenerge resp. anti-adrenerge werking en bijwerking (alfa- en betasympathicomimetica en -lytica)

2. farmaca met een cholinerge resp. anticholinerge werking en bijwerking (parasympathicomimetica en -lytica)

Ad 1:

Stimulatie van de alfareceptoren van de blaasbodem en de blaashals veroorzaakt een vernauwing van de blaasuitgang. Een voorbeeld van een farmacon met deze werking is efedrine. Dit mididel heeft tevens een stimulerende invloed op de betareceptoren met blaasverslapping tot gevolg.

Blokkade van de alfareceptoren doet de gladde musculatuur van de blaasuitgang ontspannen met een daling van de blaasuitgangsweerstand als gevolg. Aangezien de gladde spieren van het genitale buizensysteem overwegend via alfareceptoren worden geïnnerveerd, kan bij toediening van alfasympathicolytica, de emissie gestoord raken (Swaab, 1977).

Medicamenten met een alfablokkerende werking zijn o.a.: fenoxybenzamine, fentolamine en prazosine. Medicamenten met een indirect sympathicolytisch effect zijn: guanethidine, reserpine en methyldopa. Reserpine en methyldopa kunnen een erectievermindering veroorzaken.

Retrograde ejaculatie kan optreden na prostatectomie of bij diabetes mellitus. Dit kan tegengegaan worden door toediening van alfasympathicomimetica.

Stimulatie van de betareceptoren leidt tot blaasdrukverlaging en blokkade van de betareceptoren, tot drukverhoging van blaas en verhoging van de blaasuitgangsweerstand. Blokkade van de betareceptoren kan optreden bij gebruik van propranolol, metoprolol en oxprenolol.

\section{Ad 2:}

De termen parasympathicomimetica en cholinergica worden veelal door elkaar gebruikt, maar zijn niet synoniem. Immers er zijn cholinergica met een muscarine- en met een nicotinewerking. Slechts de eerste groep mag men parasympathicomimetica noemen. Deze werken op perifere autonome effectorcellen en de receptorplaatsen worden geblokkeerd door atropine. De cholinergica met een nicotinewerking stimuleren of (in hoge dosis) blokkeren de autonome ganglia en motorische eindplaten van de skeletspieren. Deze laatste werking wordt geblokkeerd door curare. Farmaca met een parasympathicomimetische werking worden verdeeld in directe en indirecte parasympathicomimetica. Tot de eerste groep behoren de choline-esters. Een farmacon met deze werking is carbachol. 
Een voorbeeld van de tweede groep zijn choline-esterase remmers als pyridostigmime, neostigmine en distigmine.

De cholinerge transmissie wordt, afhankeli k wan de localisatie, door verschillende stoffen geblokkeerd:

a. de ganglia door ganglionblokkeerders

b. de motorische eindplaat door curare

c. de postganglionaire parasympathische eindtakken door parasympathicolytica.

Een farmacon met een perifeer anticholinergische (dus parasympathicolytische) werking is atropine. Ook antihistaminica hebben als bijwerking een perifeer anticholinergisch effect. Tevens zijn er een aantal atropine-achtige stoffen als propantheline en oxyfenonium, die tevens een ganglionblokkerende werking hebben. Aangezien de cholinerge innervatie ook bij de erectie een rol speelt kunnen bij het gebruik van deze farmaca erectiestoornissen optreden.

Een aantal andere farmaca, die invloed hebben op de mictie en erectie zijn: orfenadrine door zijn centraal anticholinergische werking, dopaminergica, neuroleptica en tranquillizers door hun centraal anticholinergische bijwerking. De neuroleptica (met name de fenothiazines) hebben tevens een alfareceptor blokkerende werking.

Thymoleptica hebben hun invloed op de mictie, erectie en ejaculatie via de affiniteit tot de acetylcholine receptoren en blakkade van alfaadrenerge receptoren. Zij interfereren bovendien met de catecholaminestofwisseling in het centrale zenuwstelsel en de periferie (Cole, 1981).

Ganglionblokkeerders zoals pentolonium remmen zowel sympathische als parasympathische ganglia en hebben dus eveneens een anticholinergische bijwerking. Er zijn echter ook farmaca met een rechtstreekse werking op de detrusorspier, zoals flavoxaat en waarschijnlijk prostaglandines.

Zonder te streven naar volledigheid is in tabel 2.2 een overzicht gegeven van de verschillende farmaca met hun werking en bijwerking (De Bruin en Vereecken, 1978). 
Farmaca met een adrenerge werking en biwerking

werkingswijze

alfastimulators

alfablokkeerders

betastimulators

betablokkeerders urethra blaas

1

$\downarrow$

(1)

$-$

$\uparrow$

geneesmiddel

efedrine, oestrogenen

fenoxybenzamine, fentolamine, guanethidine, reserpine, methyldopa

ritodrine, gestagenen propranolol, oxprenolol, metoprolol

acetylcholine, carbachol, pyridostigmine

anticholinergica

$\downarrow \uparrow \quad \uparrow$

propantheline, dopaminergica, antidepressiva, ganglionblokkeerders, antihistaminica, neuroleptica (met name fenothiazines)

i = drukverhoging

$\downarrow$ = drukverlaging 


\section{NEUROLOGISCHE ASPECTEN VAN DIABETES MELLITUS IN HET KADER VAN DEZE STUDIE}

\subsection{NEUROPATHIE}

Neuropathie is één van de meest voorkomende complicaties van diabetes mellitus. Daarbij kan leder gedeelte van het perifere zenuwstelsel aangetast worden. Het zenuwstelsel is zó vaak bij diabetes mellitus betrokken, dat men in de negentiende eeuw zelfs dacht dat deze ziekte primair neurogeen werd veroorzaakt (Ellenberg, 1982).

De meest opvallende eigenschappen van de diabetische neuropathie zijn de diversiteit van de symptomen, de pathogenese en de onderzoeksbevindingen.

Zo zijn er wat betreft de pathogenese aanwijzingen voor een vasculaire origine (vasa nervorum, arteriolen, arteriën), maar ook voor een primaire segmentale demyelinisatie of axonale degeneratie als oorzaak.

De klinische verschijnselen omvatten een polymorle groep van syndromen, variërend qua tijdsintensiteitsprofiel van een acuut begin met korte duur en reversibiliteit, tot een geleidelijk begin met progressie en irreversibiliteit.

Het is moeilijk deze uiteenlopende waarnemingen en hypothesen in een pathogenetisch concept onder te brengen. Veeleer is het zo dat zij verschillende aspecten van het ziektebeeld vertegenwoordigen.

Enkele classifficaties van diabetische neuropathie zijn gebaseerd op de localisatie, het type van de zenuwaandoening, de ernst van de geassocieerde vasculaire laesies en van de degeneratieve fenomenen. De meeste classificaties echter berusten op klinische waarnemingen (Garland, 1960; Ellenberg, 1982). Tenslotte zijn er ook classificaties, die zowel op kliniek als op pathogenese gebaseerd zijn (Rundles, 1950).

Hoewel er geen eenstemmigheid is over de klinische classificatie, zijn er twee vormen van neuropathie waar in het algemeen wel overeenstemming over bestaat: de somatische en de autonome neuropathie. 
De internist Ellenberg (1982) stelde de volgende classificatie (tabel 3.1) op (waarin overigens een weinig exacte neurologische terminologie word gebruikt):

Tabel 3.1

Classificatie van diabetische neuropathie

1. Somatische neuropathie

a. onderste extremiteiten:

b. bovenste extremiteiten

c. asymmetrische neuropathie:

d. diabetische neuropathische cachexie

II. Viscerale neuropathie:

a. ogen

b. tractus digestivus:

c. tractus urogenitalis:

d. orthostatische hypotensie anhydrose vasomotorische instabiliteit.
- perifere neuropathie en radiculopathie vaak met neuropathische ulcera

- perifere neuropathie en radiculopathie

- mononeuropathie of mononeuropathia multiplex

- klapvoet

- oogspierverlammingen

- diabetische amyotrofie
- oesofagus neuropathie

- maaglatonie

- dunne darm: diabetische enteropathie, malabsorptie, diarrhoea ten gevolge van pancreasaandoeningen waaronder de cystoneuropathie retrograde ejaculatie impotentie

Daar wij in het kader van dit onderzoek vooral zijn geinteresseerd in neurogene stoornissen van het urogenitalle systeem worden deze uitgebreider behandeld dan de overige complicaties bij diabetes mellitus. 


\subsubsection{SOMATISCHE NEUROPATHIE}

Met enige modificatie van bovenstaande classificatie vain Ellenberg zou naar huidige inzichten een dergelijk schema (tabel 3.2) wat betreft de somatische neuropathie er als wolgt kunnen uitzien (Hogenhuis en Clifford Rose, 1984):

Tabel 3.2

Somatische neuropathie

bilateralle (min of meer symmetrische) polyneuropathie:
a. sensibele neuropathie
b. motorische neuropathie
c. quadriparetische vorm

mononeuropathie en mononeuropathia multiplex:

a. hersenzenuwen en perifere zenuwen

b. radiculopathie

\subsubsection{BILATERALE (MIN OF MEER SYMMETRISCHE) POLYNEUROPATHIE}

\section{a. Sensibele neuropathie}

Een bilaterale voornamelijk sensibele distale neuropathie met pijn en paraesthesieën is de meest voorkomende vorm van diabetische neuropathie. De benen zijn in het algemeen meer aangedaan dan de armen. Het begin is geleidelijk. De pijn kan variëren van flauw tot hevig, krampachtig van karakter, brandend, of zelfs snijdend en treedt vooral 's nachts op. De pijn vermindert door beweging. Hyperpathie kan zo sterk zijn, dat de patient het aanraken door kledingstukken of beddegoed niet kan verdragen. De paraesthesieën bestaan uit een koud, stijf, tintelend of branderig gevoel. Soms heeft de patient het gevoel alsof hij op kussens loopt of dat de voeten dood aanvoelen.

Mannen en vrouwen zijn in gelijke mate aangedaan, zij het dat de neuropathie aan de armen bij mannen vaker voorkomt dan bij vrouwen (Hogenhuis en Clifford Rose, 1984). Er is een voorkeur voor de hogere leeftijd. Ook depressie, prikkelbaarheid en anorexie kunnen belangrijke factoren zijn in het klinische beeld.

Hoewel het verband tussen de anorexie en de psychische verschijnselen enerzijds en de neuropathie anderzijds wooralsnog onduidelijk is, blijken deze verschijnselen te verminderen bij herstel van de neuropathie.

Bij neurologisch onderzoek worden sensibiliteitsstoornissen gevonden, voornamelijk van het gnostische systeem. De sensibiliteitsstoornissen kunnen vergezeld gaan van krachtsverlies in beide armen en benen. Bij neurologisch onderzoek van de bovenste extremitei. ten zilet men vrij regelmatig een uitgesproken atrofie in het spatium interosseum 1. Deze atrofie is symmetrisch. Daarnaast ziet men wel atrofie van de andere $\mathrm{mm}$. interossei van beide handen, alsmede de spieren van de duimmuis, de pinkmuis en de onderarmen. De meest consistente bevinding is de afwezigheid van de beenreflexen, met name van de achillespeesreflex. Bij afwezigheid van deze reflexen moet men, ook als dit bij de oudere mensen gevonden wordt, denken aan de mogelijkheid van het bestaan van diabetes mellitus.

De pijnlijke perifere neuropathie herstelt goed en opvallend is: hoe ernstiger de pijn hoe beter de prognose. Het herstel kan reeds optreden na enkele weken, doch soms ook pas na een jaar. De klachten verdwijnen dan, doch de neurologische verschijnselen, zoals vermindering van pijnperceptie, positie- en vibratiezin "niet. 


\section{b. Motorische neuropathie (diabetische amyotrofie)}

De diabetische amyotrotie werd voor het eerst door Garland beschreven (Garland en Taverner, 1953; Garland, 1955). Hij beschouwde dit syndroom aanvankelijk als een myelopathie, vanwege het patroon van de motorische uitval en de aanwezigheid van een pathologische voetzoolreflex. In 1955 veranderde hij de naam van het ziektebeeld in diabetische amyotrofie, aangezien parese en atrotie van de spieren de enige constante verschilinselen waren. De aandoening is meestal beperkt tot de spieren van bekkengordel en dij en betreft onder meer de $\mathrm{m}$. quadriceps femoris. De spieren zijn meestall asymmetrisch of slechts eenzijdig aangedaan. De parese ontstaat acuut met snel optredende atrofie en vaak hevige pijn in het gebied van de uitwal. Er zijn weinig of geen sensibiliteitsstoornissen. De bijbehorende reflexen zijn verlaagd of afwezig. Fasciculaties worden af en toe gezien.

Het syndroom komt meestal voor bij oudere niet insuline afhankelijke diabetici en kan het eerste symptoom zijn van diabetes mellitus. De pijn en de parese zijn over het algemeen reversibel in enkele maanden. De atrofie en de elektromyografische veranderingen kunnen veel langer duren en worden soms gevolgd door een symmetrische polyneuropathie.

\section{c. Quadriparetische vorm}

Quadriparetische vormen zijn klinisch moeilijk te onderscheiden van het Guillain-Barré syndroom.

De bilaterale polyneuropathie gaat vaak gepaard met een neuropathische arthropathie en neuropathische ulcera.

De reeds door Charcot bij tabes dorsalis beschreven arthropathie werd in 1936 woor het eerst bij diabetes mellitus waargenomen (Ellenberg, 1982). Meestal zijn de voet- en enkelgewrichten aangedaan en slechts zelden de knie of de wervelkolom. Opmerkelijk is de pijnloosheid. De voet wordt langzaam dikker, korter en breder met een tendens tot eversie en externe rotatie. Het voetgewelf verdwijnt. De voet gaat üteindelijk lijken op een horrelvoet en voelt bij palpatie als een 'zak met botten' aan. De arthropathie ontstaat bij een laesie van vezels voor pijn en propriocepsis. Vasculaire insufficiëntie, infectie en langdurig herhaalde kleine traumata kunnen hierbij van invloed zijn.

De arthropathie treedt meestal op bij een lang bestaande diabetes mellitus met een voorkeur voor de leeftijd van 50 tot 60 jaar.

Neuropathische ulcera treden vrijwel uitsluitend op aan de voetzolen en veroorzaken geen pijn. Zij zijn het gevolg van druk op de voet bij een verminderce sensibiliteit vooral van de pijn- en temperatuurkwaliteiten. Het ullcus is circulair en ziet er 'uitgeponst' uit.

\subsubsection{MONONEUROPATHIE EN MONONEUROPATHIA MULTIPLEX}

\section{a. Hersenzenuwen en perifere zenuwen}

Deze beelden worden gekarakteriseerd door een voorkeur voor een aandoening van hersenzenuwen of perifere zenuwen. Het begin is acuut. De aandoening gaat gepaard met hevige pijn en heeft een goede prognose. De hersenzenuwen die kunnen zijn aangedaan zijn vooral de oogspierzenuwen, $n$. facialis en $n$. vagus. Van de perifere zenuwen moeten de $n$. femoralis, $n$. peroneus, $n$. obturatorius, $n$. ischiadicus, $n$. ulnaris en $n$. medianus met name genoemd worden. Aan de uitval van de oogspierzenuwen kan ernstige pijn rond het oog voorafgaan gedurende 3 tot 7 dagen. Na de pijn ontstaat de verlamming abrupt. Volledig herstel volgt meestal binnen 6 tot 12 weken. Soms treedt een recidief op.

\section{b. Radiculopathie}

Radiculopathieên kunnen enkel- of dubbelzijdig optreden. Zij gaan vaak gepaard met paraesthesieën en pijn die varieert van licht tot hevig en vaak brandend van karakter is. $E r$ is een voorkeur woor de zenuwwortels $L 2$ tot $L 5$, doch ook de cervilcale en thoracale zenuwwortels kunnen aangedaan zijn. 


\subsubsection{AUTONOME NEUROPATHIE}

Sinds John Langley in 1898 zijn concept over het autonome zenuwstelsel beschreef, is men er in toenemende mate mee vertrouwd geraakt dat het autonome zenuwstelsel bij een variëteit van ziekten betrokken is. Diabetes mellitus is de meest voorkomende hiervan (Fagerberg et al. "1967),

De klinische verschijnselen bij diabetes, die aan een autonome neuropathie worden toegeschreven, zijn bekend sinds het klassieke werk van Rundles in 1945.

Diabetische autonome neuropathie kan een functiestoornis in vrijwel ieder orgaan van het lichaam veroorzaken. Vooral de cardiovasculaire, gastro-intestinale, sudomotorische, vasomotorische, endocriene en urogenitale systemen zijn hierbij betrokken.

De symptomen bij autonome neuropathie beginnen vaak geleideliij $k_{\text {, }}$ ijn variabel en hebben geen typisch patroon in de eerste stadia. In zijn lichtste vorm blijft de autonome neuropathie subklinisch en wordt dan alleen ontdekt door autonome functietests; bij ernstige vormen kan de patient invalide zijn of kan zelfs zijn leven bedreigd worden (Ewing et al., 1976). Tot voor kort had men moeite met het aantonen van lichte autonome functiestoornissen zoals die kunnen voorkomen bij diabetes mellitus. De ontwikkeling van eenvoudige, niet invasieve onderzoekmethoden heeft hier verbetering in gebracht samen met farmacologische metingen.

Autonome neuropathie kan tot complicaties leiden. Een atone blaas bijvoorbeeld kan aanleiding geven tot urineweginfectie en daardoor tot een verminderde nierfunctie. Diabetici met symptomen van een autonome neuropathie hebben in het algemeen ook verschijnselen van somatische neuropathie.

Sympathische laesies bij diabetes hebben vooral een postganglionaire localisatie en parasympathische laesies een preganglionaire (Hosking et al., 1978).

Het parasympathische systeem is over het algemeen eerder aangledaan dan het sympathische, dat eventueel gespaard kan blijven (Hosking et al., 1978).

Bij de beschrijving van de autonome neuropathie wordt de indeling gevolgd zoals aangegeven door Clarke et al. (1980). (tabel 3.3)

Tabel 3.3

\section{Autonome neuropathie}

cardiovasculaire systeem: a. hartritmeverandering

b. orthostatische hypotensie

c. pijnloos hartinfarct

gastro-intestinale systeem: $\quad a_{\text {. }}$ stoornissen van de oesofagusmotiliteit

b. stoornissen van de maagmotiliteit

c. stoornissen van de darmmotiliteit

pupillen

sudomotorische systeem

vasomotorische systeem

endocriene systeem

urogenitale systeem
a. blaas
b. geslachtsorganen

\subsubsection{CARDIOVASCULAIRE SYSTEEM}

\section{a. Hartritmeverandering}

Diabetici met een autonome neuropathie hebben gewoonlijk een toegenomen hartfrequentie in rust van ongeveer $90-110 / \mathrm{min}$. Ook hebben de diabetici als groep een hogere 
gemiddelde hartfrequentie vergeleken met leeftijds- en sexegenoten (Ewing et al., 1974). Deze frequentie is stabiel en reflexmatig te beinvioeden, bijwoorbeeld door massage van de sinus caroticus. De toegenomen hartfrequentie wordt veroorzaakt doordat de parasympathische vezels meer zijn aangedaan dan de sympathische.

De normale respiratoire arythmie is bij diabetische autonome neuropathie verminderd of afwezig.

\section{b. Orthostatische hypotensie}

Orthostatische hypotensie is het meest significante symptoom van een autonome neuropathie van het cardiovasculaire systeem. Het is een laat verschijnsel en gaat vaak samen met andere symptomen van de kant van het autonome systeem.

Orthostatische hypotensie wordt gedefinieerd als een daling van de systolische bloeddruk van $30 \mathrm{mmHg}$ of meer bij verandering van liggende naar staande houding (Clarke et al., 1979). De daling van de diastolische bloeddruk is minder uitgesproken, maar kan bij sommige patienten aanmerkelijk zijn. Symptomen treden in het algemeen op wanneer de systolische bloeddruk bij houdingsverandering van liggen naar staan daalt tot onder de $70 \mathrm{mmHg}$. De patient bemerkt dan draaiduizelingen en neigt tot flauwvallen. Perioden van enkele minuten bewusteloosheid, focale neurologische stoornissen, of amaurosis fugax kunnen optreden, vooral 's morgens vroeg bij het opstaan. Wanneer een neuropathie aanwezig is en de compensatoire baroreflexmechanismen insufficiënt zijn, treedt orthostatische hypotensie op.

Aanvankelijk subklinische orthostatische hypotensie kan symptomen gaan geven bij gebruik van medicamenten die de bloeddruk verlagen, zoals antihypertensiva, diuretica, tricyclische antidepressiva en phenotiazinen, en bij ziekten met dehydratie. Insuline kan bij autonome neuropathie de orthostatische hypotensie versterken (Page en Watkins, 1976). Ook is er bil patienten met een autonome neuropathie geen plasma renine toename na. staan, waardoor een orthostatische hypotensie optreedt (Campbell et al., 1976).

\section{Pijioos hartintarct}

Bii diabetes met een autonome neuropathie komen pijnloze myocardinfarcten vaker voor (Faerman et al., 1977). Dit is te verklaren door een laesie van de afferente viscerale vezels.

\subsubsection{GASTRO-INTESTINALE SYSTEEM}

\section{a. Stoornissen van de oesofagusmotiliteit}

Stoornissen van de oesofagusmotiliteit leiden meestal niet tot symptomen. Soms worden dysfagie en substernale klachten zoals zuirbranden opgemerkt. Bij radiologisch onderzoek met behulp van bariumcontrast ziet men vooral bij liggende patienten dilatatie, verminderde doch gecoördineerde peristaltiek van de oesofagus, en vertraagde lediging naar de maag. Bij cineradiografie is de primaire golfbeweging van de oesofagus verminderd of afwezig en zijn contracties aanwezig.

Gastro-oesofagale reflux is echter ongewoon. Al deze verschijnselen zijn te verklaren door een laesie van de pregianglionaire parasympathische vezels (Hosking et al., 1978).

\section{b. Stoornissen van de maagmotiliteit}

Vertraagde maaglediging als neurologische complicatie werd het eerst beschreven door Rundles (1945). Kassander (1958) introduceerde hiervoor de term 'gastroparesis diabeticorum'. De musculatuur van de maag wordt geïnnerveerd door parasympathische vezels via de $n$. vagus en door sympathische vezels uit de plexus coeliacus en wordt tevens beinvloed door hormoonsecretie in de tractus gastro-intestinalis.

Maagdilatatie geeft over het algemeen geen klachten en kan een toevallige radiologische bevinding zijn (Kassander, 1958).

Indien er wel symptomen optreden dan klaagt de patient over anorexie en een opgezet 
gevoel na de maaltijd. Deze symptomen ontstaan in de regel geleidelijk, doch kunnen ook acuut optreden. Bij toename van de klachten treedt er misselijkheid, braken en hikken op, vaak aanvalsgewijs en met een duur van enkele dagen.

Röntgenbeelden verkregen met behulp van bariumcontrast tonen een toename van het nuchter residu, een verwijde $J$-vormige maag tot 2 á 3 maal de normalle grootte, verminderde of afwezige peristaltiek en een vertraagde lediging ondanks een wijd openstaande pylorus (Cooke, 1975).

Bij gezonde mensen verlaat vast voedsel de maag langzamer dan woeibaar voedsel. Bij diabetici is dat verschil er echter niet (Campbell et al., 1977).

Tesamen met atonie van de maag vindt men vaak atonie van duodenum en galblaas (Clarke et al., 1980). Een maagulcus treedt zelden op.

\section{c. Stoornissen van de darmmotiliteit}

Radiologisch onderzoek van de dunne darm met behulp van bariumcontrast toont een normale of vertraagde lediging, verwijd lumen, grove en onregelmatige mucosaplooien en gestoorde motiliteit. Een biopsie van de dunne darm toont geen afwijkingen.

Naast atonie van de dunne darm ziet men bij de autonome neuropathie ook atonie van het colon met een sterke toename van het lumen (megacolon).

Er zijn afwijkingen gevonden in zowel sympathische als parasympathische innervatie van de darm.

Faecale incontinentie kan berusten op verlies van de controle over de $\mathrm{m}$. sphincter ani externus. Mogelijk is dit het gevolg van beschadiging van efferente vezels van de $\mathrm{m}$. sphincter ani externus (Katz en Spiro, 1966).

\subsubsection{PUPILLEN}

Afwijkingen van de pupilreflex in combinatie met diabetische neuropathie werden reeds beschreven door Riundles (1945). De belangrijkste stoornissen zijn een kleine pupildiameter, een vertraagde of afwezige lichtreflex met een intacte convergentie- en accommodatiereactie. Een echte Argyll-Robertson pupil is zeldzaam.

Smith et al. (1978) verrichtten bij 36 insuline afhankelijke diabetici metingen met een binoculaire infrarood pupillometer. Hij toonde aan, dat bij diabetici een abnormaal kleine verwijding van de pupil ontstond in het donker en dat er significant minder schommelingen in de pupildiameter optraden gedurende continue blootstelling aan sterk licht.

\subsubsection{SUDOMOTORISCHE SYSTEEM}

Sudomotorische activiteit maakt deel uit van de thermoregulatie en wordt geregeld door centrale receptoren in de hypothalamus. Er is een geintegreerd efferent systeem, dat bestaat uit pre- en postganglionaire sympathische vezels met cholinerge innervatie van de eccriene zweetklieren. Deze klieren zijn gelijkmatig en diffuus over het lichaam verspreid. Bij te sterke stijging van de endogene of exogene temperatuur ontstaat een algemene zweetsecretie. Verminderde of opgeheven zweetsecretie ontstaat ten gevolge van een laesie van de postganglionaire sudomotorische vezels. Naast de verminderde zweetsecretie vindt men ook vaak vasomotorische stoornissen en een sensibele perifere neuropathie in het gebied van de anhydrose. Het anhydrotische gebied is gewoonlijk symmetrisch verspreid over voeten en benen. Bij ernstige anhydrose breidt het gebied zich wit naar de onderste helft van de romp en een enkele keer doen ook beide armen mee. Het transpireren op emotionele basis, dat afhankelijk is van het intact zijn van de eccriene klieren, is ook afwezig in beide voeten. De apocriene kliersecretie, zoals in de oksels, blijft onveranderd omdat de desbetreffende zweetklieren geen innervatie hebben. De anhydrose leidt tot fissuren en infecties ter plaatse (Clarke et al., 1980). 
Rundles (1945) beschreef bil diabetici met een ernstige polyneuropathie een toename wan de zweetsecretie over het bovenste deel van de romp en wan het hoofd. De verklaring hiervoor zou kunnen zijn een compensatoire toename van zweten in de niet gelaedeerde gebieden (Goodman, 1966).

Watkins beschreef in 1973 gustatoir zweten bij patienten met een autonome neuropathie. Dit is zweten over gelaat, hoofd en hals gedurende de maaltijd. Het wordt geprovoceerd door het gebruik van kaas, specerijen, alcohol en azijn, en kan binnen enkele secondien ontstaan. Men denkt dat dit het gevolg is van een abnormale regeneratie van parasympathische salivatorische vezels die de zweetklieren gaan innerveren in het gebied van het ganglion cervicale superius (Watkins, 1973).

\subsubsection{VASOMOTORISCHE SYSTEEM}

Zowel abnormale vasodilatatie als abnormale vasoconstrictie kunnen optreden in de gedenerveerde vaten (Martin, 1953), doch zelfs bij een uiltgesproken autonome meuropathie kunnen deze veranderingen minimaal of afwezig zijn (Friedman et al., 1972). Abnormale vasodilatatie kan worden veroorzaakt door een laesie van de sympathische vezels, die een rol spelen bij de vasoconstrictie.

Martin (1953) meldde een abnormale vasodilatatie in $50 \%$ van de onderzochte patienten met een autonome neuropathie. Bij deze patienten vindt men in tegenstelling tot normaal dat de huidtemperatuur van de tenen hoger is dan die van de vingers (Martin, 1953). Bij sterke verlaging van de lichaamstemperatuur ontbreekt de vasoconstrictiereflex van de huidvaten van de voet (Martin, 1953).

Odel et al. (1955) meldden een excessieve fysiologische vasoconstrictie in beide handen, mogelijk om de lichaamstemperatuur op peil te houden als reactie op het ontbreken van een vasoconstrictie in de onderste helft van het lichaam.

Martin (1953) vond in $50 \%$ "van zijn patienten met een autonome neuropathie een abnormale vasoconstrictie in handen, voeten en kuiten. Dit kan het gevolg zijn van een ontbreken van de vasodilatatiereflex, die normaal optreedt bij toename van de $\|$ ichaamstemperatuur.

\subsubsection{ENDOCRIENE SYSTEEM}

Bij een daling van de bloedsuikersplegel ontwikkelen insuline afhankelijke diabetici eerst een parasympathische reactie, die gewoonlijk asymptomatisch verloopt, doch begeleid kan zijn door bradycardie en hypotensie.

Dil wordt gevolgd door een fase van verminderde cerebrale functies met symptomen die niet constant aanwezig zijn, zoals matheid en geeuwen. Daalt de bloedsuikerspiegel verder dan ontstaan bij de meeste patienten herkenbare symptomen zoals angst, tremor, hartkloppingen en transpireren ten gevolge van een sympathische reactie. Dit laatste is het gevolg van het vrijkomen van catecholaminen uit het bijniermerg en de adrenerge zenuwuiteinden.

Patienten met een autonome neuropathie kunnen ook klagen over een verandering van de aard van hun hypoglycaemische aanvallen. De herkenbare symptomen kunnen verdwijnen (Sussman et al., 1963), zodat zij plotseling bewusteloos raken. Men denikt dat de oorzaak hiervan het ontbreken van een sympathische reactie is. Eerder dan de sympathische reactie treedt de vagale glucagonreactie op. Hierbij komt glucagon vrij uit de alfacellen van de eilandjes van Langerhans welk fenomeen afhankelijk is van een intacte $n$. vagus (Bloom et al., 1974). Deze reactie is belangrijk voor de mobilisatie van glucose. Deze glucagonsecretie als reactie op een door insuline geinduceerde hypoglycaemie is aanzienlijk gereduceerd en kan zelfs afwezig zijn bij langdurig bestaande diabetes mellitus met een autonome neuropathie. Dit kan de oorzaak zijn van een snelle daling van het bloedsuikergehalte met als gevolg een acuut bewustzijnsverlies. 
Het ontbreken van deze reactie kan echter ook een zeer vroeg symptoom zïn van een autonome neuropathie (Camplbell et al., 1977).

Zoals reeds eerder vermeld, kunnen patienten met cen autonome neuropathie en een orthostatische hypotensie plotseling bewusteloos raken na een injectie van een snel wer. kend insuline preparaat. De oorzaak hiervan is volgens Page en Watkins (1976) niet de hypoglycaemie doch de door insulinetoediening geinduceerde orthostatische hypotensie. Dit kan verklaard worden door een verandering van de permeabiliteit van de endotheelcellen van de capillairen voor insuline. Hierdoor komt albumine en water in de extracellulaire ruimten met als gevolg een vermindering van plasmavolume. Verandering van tijdstip van insuline-injectie kan deze aanvallen voorkomen.

\subsubsection{UROGENITALE SYSTEEM}

\section{a. Blaas}

Kenmerkend voor het klinische beloop van een blaasfunctiestoornis bij diabetici is het geleidelijk ontstaan van een blaasparalyse met urineretentie (Ellenberg, 1980). De eerste symptomen worden vaak niet opgemerkt en vallen pas op als de ziekte in een vergevorderd stadium is.

De frequentie van de mictie neemt geleidelijk af tot 1 á 2 maal per dag. Vaak wordt lediging van de blaas ondersteund door manuele druk. Nog weer later ontstaat een traag op gang komen van de mictie, verzwakking van de straal (druppelsgewijs) en het gevoel van onvolledige lediging. Uiteindelijk treedt een decompensatie van de blaas op en ontstaat retentie. Dit ziet men vooral bij een lang bestaande diabetes mellitus.

Blaasfunctiestoornissen als complicatie van diabetes mellitus werden voor het eerst gemeld door Marchal de Calvi (1864). Dat vaak een neurogene aandoening hieraan ten grondslag ligt, is al meer dan 50 jaar bekend (Smith en Engel, 1932; Jordan en Crabtree, 1935).

Voor de diagnose diabetische cystoneuropathie zijn in de loop der jaren uiteenlopende criteria gehanteerd. Ellenberg (1966) spreekt van een cystoneuropathie als er een retentie is, een hypotone cystometrische curve met ontbreken van eerste aandrang en een niet geobstrueerde blaashals. Volgens Fagerberg et al. (1967) moet de blaascapaciteit meer dan $600 \mathrm{ml}$ zijn en moet de blaashals zich moeilijk openen, zoals gezien kan worden bij mictiecysto-urethrografie bij 2/3 van de diabetes mellitus patienten. Kahan et al. (1970) stellen dat de retentie meer dan $90 \mathrm{ml}$ zou moeten bedragen en dat de blaascapaciteit tot meer dan $400 \mathrm{ml}$ zou moeten zijn toegenomen. Zij zijn bovendien van mening dat een somatische neuropathie aanwezig moet zijn. Faerman et al. (1971) zijn van mening dat de blaascapaciteit groter dan $500 \mathrm{ml}$ moet zijn en tenslotte spreken Hopkin en Pierce (1967) pas van een pathologisch verhoogde blaascapaciteit indien deze groter is dan 700 $\mathrm{ml}$.

De methoden voor evaluatie van de blaasfunctie zijn de laatste 10 jaren echter zeer uitgebreid. Daardoor is het mogelijk geworden om de pathofysiologie van de blaas te bestuderen en te differentiëren tussen functionele en mechanische blaasuitgangsstoornissen. Aan de hand van zulk onderzoek stelde Frimodt-Møller (1978) de volgende criteria op voor een diabetische cystoneuropathie:

1. een vermindering van blaasgevoel (prikkeldrempel hoger dan $15 \mathrm{~mA}$ )

2. een toegenomen blaascapaciteit zonder aanwijzingen voor een mechanische blaasuitgangsobstructie en zonder stoornissen in het viscero-motorisch neuron naar de blaas. Salama Benarroch et al. (1979) onderzochten de contractiecapaciteit van de blaas door meting van de maximale mictiedruk. Uit dit onderzoek blijkt dat bij $2 / 3$ van de patienten met een diabetische cystoneuropathie een adequate contractiecapaciteit aanwezig is. Men kan hier de conclusie uit trekken, dat in deze gevallen diabetische cystoneuropathie niet door aantasting van de viscero-motorische zenuwvezels veroorzaakt wordt. Deze waarneming komt grotendeels overeen met de mening van Frimodt-Møller (1978). 
Twintig tot veertig jaar geleden (Rundles, 1945; Aarseth, 1953) werd een frequentie van voorkomen van blaastunctiestoormissen bil diabetes mellitus vermeld van 0,4 tot $1,0 \%$ Hierbii werd echiter uitsluitend uitgegaan van de spontane klachten van de patienten.

Door een toegenomen belangstelling de laatste jaren is een verbeterde anamnesetechniek ontstaan, waarbij men onder andere vraagt naar retentiegevoel, de noodzaak tot het manueel leegdrukken van de blaas (straining), toegenomen mictie-interval, verlengde mictietijd en verminderde kracht en/of onderbreking van de urinestroom. Met behulp van deze uitvoerige anamnese blijkt bil 37 tot $50 \%$ van de diabetici deze klachten aanwezig te zijn (Kahan et al „, 1970; Frimodt-Moller, 1978).

Door middel van urofysiologische technieken, zoals cystometrie, meting van het urethradrukprofiel, druk-flowmeting, en door elektromyografie van de $\mathrm{m}$. sphincter ani externus en $\mathrm{m}$. sphincter urethrae externus, verbeterden de mogelijkheden nog verder. Faerman et al. (1971) vonden zelfs bij $87 \%$ van de diabetici met behulp van deze methoden een cystoneuropathie.

Gepubliceerde studies over diabetische cystoneuropathie betreffen in het algemeen kleine aantallen patienten (maximaal 59 patienten) (Ellenberg en Weber, 1967; Faerman et al., 1971; Reed et al., 1973).

In grotere studies met insuline afhankelijke diabetici (Lich en Grant, 1948; Frimodt-Møller, 1976 a) werd bij respectievelijk 43 en $44 \%$ een cystoneuropathie gevonden. Bij insuline afhankelijke diabetici tussen 20 en 50 jaar varieert de frequentie van voorkomen van $34 \%$ (Fagerberg et al., 1967) tot 63\% (Bartley et al., 1966).

Er zlin ook enkele studies bekend over patienten die behandeld werden met orale antidiabetica of uitsluitend met diabetisch dieet (Buck et al., 1976; Firimodt-Møller, 1976b). In deze beide studies die vooral uit oudere patienten betroffen, werd in $25 \%$ van de gevallen een cystoneuropathie gevonden.

loanid et al. (1981) vond geen correlatie tussen diabetische cystoneuropathie en de leeftijd van de patient.

Blaashalsobstructie is bij mensen met diabetes mellitus beneden de 50 jaar nauwelijks aanwezig, maar neemt boven de 50 jaar toe tot 25\% (Frimodt-Møller, 1978).

De frequentie van cystoneuropathie bij mannelijke en vrouwelijke diabetici is vrijwel identiek (Frimodi-Møller, 1976a). Frimodt-Møller gaf aan dat er geen statistisch significante correlatie gezien werd tussen de dosis van insuline en de frequentie van de cystoneuropathie.

Verschillende auteurs (Faerman et all., 1971; Frimodt-Møller, 1976b) hebben aangetoond, dat de cystoneuropathie vaker voorkomt naarmate de diabetes langer duurt. Duurt de diabetes ongeveer 10 jaar bij patienten, die bij het begin jonger dan 40 jaar zjjn, dan heeft ongeveer $25 \%$ een cystoneuropathie. Van de patienten met diabetes langer dan 45 jaar heeft $50 \%$ een cystoneuropathie. Van de patienten, die bij het begin van de diabetes ouder zijn dan 40 jaar heeft na een duur van 10 jaar reeds $40 \%$ en na een duur van 30 jaar ongeveer 50\% een cystoneuropathie. Frimodt-Moller (1976a) en Fagerberg et al. (1977) konden geen verband aantonen tussen cystoneuropathie en regulatie van de diabetes. Het tijdstip van optreden van cystoneuropathie is individueel onvoorspelbaar. Ofschoon cystoneuropathie gewoonlijk gevonden wordt bij langer bestaande diabetes kan het het eerste verschijnsel zijn (Ellenberg, 1963) en kan het aanwezig zijn zonder tekenen van polyneuropathie.

Faerman et all. (1971) onderzochten 32 juveniele diabetici zonder unologische klachten. Bij 27 van hen werden urodynamische afwijkingen gevonden $(87 \%)$. Een soortgellijk percentage werd ook door Sallama Benarroch et al. (1979) vermeld.

In het stadium zonder urologische klachten maar met afwijkingen bij cystometrie en een vergrote blaas is er meestal geen bacteriurie, geen glucosurie, geen azotaemie, sepsis, albuminurie of retentie. Bij de gedecompenseerde diabetische neurogene blaas treden echter wel klachten op en ontstaat retentie met infectie.

Salama Benarroch et al. (1979) vonden retentie bij alle diabetici met een geïnfecteerde blaas.

Treffend is de afwezigheid van nycturie bij diabetes mellitus. De eerste ochtendportie is 
frequent boven de $1000 \mathrm{~m} /$ en in velle gevallen zelfs tot $1300 \mathrm{ml}$ (Faerman et al., 1971). De urine wordt 's nachts geproduceerd in een ongevoelige blaas. De grote ochtendmictie is een belangrijk teken waarbij men moet denken aan een diabatische cystoneuropathie (Salama Benarroch et al., 1979). De patient met een gedecompenseerde blaas wordt menigmaal met een niet correcte diagnose opgenomen, onder andere buiktumor, ovariumtumor, metastasen in het peritoneum, ascites, pyelonefritis, prostaathypertrofie en darmobstructie. De patienten zijn zich meestal niet bewust van een dysfunctie van de

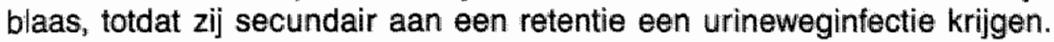

Toename van mictiefrequentie en dysurie wijzen op een geinfecteerde blaas. De infectie kan zich snel verspreiden en zelfs soms fataal zijn. Acute urineretentie komt zelden voor.

\section{b. Geslachtsorganen}

Potentiestoornissen zijn beschreven in 15 tot $75 \%$ van diabetici in verschillende leeftijdsgroepen (Rundles, 1945; Rubin en Babboth, 1958; Aagenaes, 1963; Schöffling et al., 1963; Faerman et al., 1969, 1971 en 1974; Ellenberg, 1971; Reed et al. "1973; FrimodtMøller, 1976b en Fagerberg et al., 1967).

Aagenaes (1963), Ellenberg (1971), Faerman et al. (1971) en Reed et al. (1973) vonden bij 78 tot $83 \%$ van de diabeticl met impotentie een cystoneuropathie. Frimodt-Møller (1976b) vond daarentegen geen relatie tussen impotentie en diabetische cystoneuropathie.

Impotentie kan het enige autonome symptoom zijn bij patienten met diabetes mellitus (Ewing et al., 1973) en zelfs de eerste klinische manifestatie van de ziekte (Rubin en Babboth, 1958). Andere oorzaken, vooral psychogene, moeten dan worden uitgesioten. Impotentie hoeft ook niet vergezeld te gaan van een perifere neuropathie (Ellenberg, 1971). Bij een follow-up onderzoek (Ewing et al., 1976) bleek, dat slechts enkele patienten met als enige symptoom impotentie andere verschijnselen van een autonome neuropathie ontwikkelden. Zijn er bij diabetespatienten klinische verschijnselen van een autonome neuropathie dan is impotentie bijna altijd aanwezig.

Rubin en Babboth (1958) vonden dat $70 \%$ van de mannelijke diabetici met een diabetesduur van minder dan één jaar impotent waren. Zij schreven dit hoge percentage toe aan de relatief hoge gemiddelde leeftijd van de patienten (50,7 jaar) en tevens aan het niet goed ingesteld zijn, want dit percentage daalde tot $43 \%$ bij eem duur tussen één en vijf jaar. Het is niet ongewoon, dat de impotentie verbetert als de diabetes goed ingestelld is. Ontstaat er impotentie bij een goed behandelde diabetes, dan is deze meestal permanent.

Schöffling et al. (1963) vonden geen significant verschil tussen het voorkomen van impotentie bij patienten met insuline of met orale antidiabetica.

Ellenberg (1971) vond geen duidelijke correlatie tussen de wijze van behandeling, de duur en de ernst van de diabetes mellitus.

Gegevens betreffende sexuele functiestoornissen bij de vrouwen zijn schaars. Kolodny (1979) vond een verlies van orgasme bij $1 / 3$ van de vrouwelijke diabetici tussen 18 en 42 jaar.

Het is belangrijk met betrekking tot de potentie een onderscheid te maken tussen enerzijds erectie en anderzijds ejaculatie. Potentie wordt gedefinieerd als het vermogen een erectie te beginnen en te houden tot een ejaculatie heeft plaatsgevonden. Een opvallend verschijnsel bij diabetes mellitus is het aanwezig blijven van libido, ondanks impotentie (Ellenberg, 1971). Schöffling et al. (1963) vonden dit bij 48,1\% van zijn diabetespatienten en Rubin en Babboth (1958) bij 100\%.

Een erectiestoornis gaat bilj diabetici gewoonlijk vergezeld van een stoornis in de ejaculatie. Soms gaat een ejaculatiestoornis vooraf aan een erectiestoornis.

Potentiestoornissen ontstaan geleidelijk en kunnen in 6 maanden tot 2 jaar tijd tot een volledige impotentie leiden. De impotentie heeft geen periodiciteit (Karacan, 1970).

Het is belangrijk dat de patient met diabetes mellitus weet, dat de impotentie organisch veroorzaakt kan worden en geen psychogene oorzaak hoeft te hebben. 
Hosking of al. (1978) geven in tabel 3.4 de criteria voor differentiële diagnose:

Tabel 3.4

Differentiaal diagnose van impotentie bij diabetes mellitus

psychogeen

Acuut begin, vaak gerelateerd aan specifieke stress-situaties.

Selectief en intermitterend aanwezig bij bepaalde gelegenheden en situaties. Beïnvloedbaar door partnerkeuze.

Ochtenderecties, nachtelijke zaadlozingen en het vermogen tot reactie op erotische prikkels blijven vaak aanwezig.

\section{organisch}

Meestal geleidelijk begin.

Soms acuut bij het begin of bij een slechte controle van diabetes mellitus.

Aanhoudend en progressief. Niet beïnvloedbaar door uitwendige omstandighedien of partner.

Ochtenderecties en nachtelijke zaadlozingen afwezig.

Libido blijft in het begin aanwezig maar vermindert bij een langere bestaansduur van de diabetes.

Schöffling et al. (1963) kwamen tot de conclusie dat impotentie en infertiliteit bij diabetici zouden berusten op een hypogonadotrofisch hypogonadisme.

Zij vonden bij $2 / 3$ van de 314 mannelijke diabetici een afname van de urine-excretie van hypofyse gonadotrofine en testosteron en een stijging van de 17 ketosteroilden, en bij $1 / 3$ van de onderzochten waren de spermatozoën aantallen in het zaad laag.

Ellenberg (1971) en Faerman et al. (1972) vonden echter normale testosteron spiegels in het plasma. Wel vonden Faerman et al. (1972) een hypospermie welke niet verbeterde met androgenen.

Een andere bij diabetes mellitus voorkomende stoornis is retrograde ejaculatie. Retrograde ejaculatie in de blaas werd bij diabetici het eerst beschreven door Green et al. (1963). Dit verschijnsel gaat gewoonlijk vooraf aan het optreden van impotentie en is het gevolg van een laesie van de $n$. hypogastricus, die de $\mathrm{m}$. sphincter urethrae internus en het trigonum innerveert.

Bij retrograde ejaculatie blijven erectie en orgasme aanwezig en in de urine worden levende en beweeglijke spermatozoën gevonden.

Het verschijnsel is of een toevalsbevinding bij urine-onderzoek of wordt ontdekt bij onderzoek naar infertiliteit en komt vaak in combinatie met een cystoneuropathie voor.

\subsection{MYELOPATHIE}

Neurologische verschijnselen passend bij een myelopathie ziet men betrekkelijk zelden bij diabetes mellitus. Het aantal publicaties daaraan gewijd is dienovereenkomstig klein in vergelijking met dat over de perifere neuropathie.

Treusch (1945) ontkende het bestaan van dit ziektebeeld.

Leval-Piquechef (1885) noemdle dit klinische beeld als eerste 'pseudotabes diabetica'. Deze term werd nog gebruikt door Logothesis en Baker in 1963, terwijl de term diabetische myelopathie door Garland en Taverner in 1953 werd gebruikt, en de term 'posterolateralle sclerosis" door Relking en Esseesse in 1976. Stoornissen van de gnostische sensibiliteit en coördinatie tesamen met areflexie zijn kenmerkend voor dit ziektebeeld. 
De symptomen van een myelopathie kunnen voorafgaan aan diabetes mellitus (Williamson, 1894, Pirart, 1965).

De eerste, die bij diabetici ruggemergspathologie waststelde, was Pryce (1893). Hil beschreef een patient met atrofie van de motorische voorhoorncellen in het thoracale deel van het ruggemerg.

Nonne (1896) beschreef een patient met degeneratie van de motorische voorhoorncellen over de gehele lengte van het ruggemerg. Woltman en Wilder (1929) en Dolman (1963) vonden een schrompeling, chromatolyse en een vermindering in aantal van de motorische voorhoorncellen, naast demyelinisatie van achterwortels.

Griggs en Olsen (1937) deelden de neuropathologische afwijkingen van het ruggemerg bij diabetes mellitus in drie groepen in:

1. degeneratie van motorische voorhoorncellen in de hersenstam en het ruggemerg

2. degeneratie van het intramedullaire deel van de vezels van de achterwortel met secundaire degeneratie van de achterstrengen (zoals ook gezien wordt bij tabes dorsalis)

3. degeneratie van de achterstrengen, vooral cervicaal en hoog-thoracaal met uitbreiding in de achterhoorn en zelden in de zijstreng.

Dolman (1963), Riedel (1965), Gupta en Dorfman (1981) vonden demyelinisatie en gliose van de achterstrengen, soms vergezeld van demyelinisatie van de achterwortel, zowel het extra- als het intramedullaire deel, met een voorkeur voor het lumbosacrale ruggemerg. Tevens vonden zij een vermindering van het aantal cellen in de spinale ganglioncellen. Slager et al. (1973) en Slager (1978) vonden geen gliose en geen voorkeurslocalisatie wat betreft de demyelinisatie. Ook vonden zij geen verband met de leeftijd van de patient en de duur van de diabetes mellitus. Zij concludeerden op basis van hun onderzoek dat demyelinisatie van de achter-en zijstreng als onafhankelijke laesie bij diabetes mellitus voorkomt. Deze demyelinisatie werd door anderen echter gezien als een uitbreiding van radiculo- en perïfere neuropathie (Woltman en Wilder, 1929; Dolman, 1963).

Spencer en Schaumberg (1976) constateerden dat de achterstrengdegeneratie en perifere neuropathie parallel verllopende manifestaties zijn van de diabetische distale axonopathie uitgaande van de spinale ganglioncellen.

De ruggemergslaesies, en vooral laesies van achter- en zijstreng, leiden slechts in de minderheid van de gevallen tot symptomen (Riedel, 1965; Slager, 1978).

Riedel (1965) onderzocht post mortem 35 patienten met diabetes mellitus zonder symptomen van achterstreng-, zijstreng- of achterwortellaesie. Bij 13 van de 35 onderzochte gevallen vond hij echter toch afwijkingen aan deze systemen. De gemiddelde leeftijd was 66,7 jaar en de duur van de diabetes 30 jaar. Als probleem gaf hij aan dat het moeilijk uit te maken was welke afwijkingen leeftijdsgebonden waren en welke veroorzaakt zouden kunnen zijn door de diabetes mellitus. De afwijkingen toegeschreven aan het ouder worden vindt men over de gehele lengte van achter-en zijstreng en motorische voorhoorncel, terwijl de veranderingen bij diabetici beperkt zijn tot delen van achter-en zijstreng, alsmede de achterwortel over meerdere segmenten.

Het voorkomen van achterstrenglaesies bij diabetes mellitus varieert van 17 tot 44\% (Dolman, 1963; Riedel, 1965; Slager, 1978). Ook bij patienten zonder klachten of aiwijkingen van de kant van het ruggemerg komt dit vrij frequent voor (Riedel, 1965).

Demyelinisatie van zowel achter- als zijstreng komt in mindere mate voor. Dolman (1963) en Kott et al. (1971) gaven een voorkomen van 6 tot 12,5\% aan. Woltman en Wilder (1929) gaven een literatuuroverzicht van 42 obducties. Bij 16 gevallen was er een laesie van de achterstrengen, bij vijf van de achterwortels en bij acht van de motorische voorhoorncellen.

Micro-infarcten in het ruggemerg komen bij het ouder worden in toenemende mate voor, zowel bij diabetici als bij niet-diabetici (Mannen, 1966). Bij diabetici is de frequentie van voorkomen hoger en de leeftijd lager (Mannen, 1966). Micro-infarcten bij diabetici hebben een voorkeur voor de witte stof en bij niet-diabetici voor de grijze stof (Slager, 1978). 
Slager (1978) vond infarcten in het ruggemerg bil 14 van 75 ongeselecteerde overleden diabetici. Veel van deze infarcten bleken veroorzaakt door atherosclerose van de intrinsieke bloedvaten van het ruggemerg. Riedel (1965) vond deze afwijking slechts in zeer beperkte mate. 


\section{HOOFDSTUK 4 \\ LITERATUURGEGEVENS BETREFFENDE \\ DE DIAGNOSTISCHE ONDERZOEKMETHODEN}

\subsection{KLINISCH-NEUROFYSIOLOGISCHE METHODEN}

\subsubsection{ELEKTROMYOGRAFIE VAN DE M. SPHINCTER ANI EXTERNUS}

\subsubsection{INLEIDING}

Contracties van spiervezels gaan gepaard met elektrische potentiaalveranderingen. De aktiviteit van spiervezels die met hetzelfde axon zijn verbonden summeert zich tot motorunitpotentialen (MUPs). Wanneer spiervezels gedenerveerd zijn gaan zil individueel spontane aktiviteit vertonen in de vorm van zogenaamde fibrillatiepotentialen en positieve scherpe golven. De laatste golfvorm kan worden beschouwd als een variatie van de fibrillatiepotentiaal, veroorzaakt door een bijkomende geleidingsstoornis langs de spiervezelmembraan. Kortheidshalve zal derhalve in het vervolg uitsluitend van fibrillatiepotentiallen worden gesproken. Bovengenoemde aktiviteit kan worden geregistreerd via een in de spier ingebrachte naaldelektrode. Meestal wordt een concentrische naaldelektrode gebruikt bestaande uit een stalen intramusculaire injectienaald (doorsnede ca. 0,5 mm) met daarin een zilveren of platina draad, welke over zijn gehele lengte geïsoleerd is van de canule. Potentiaalverschillen worden gemeten tussen het uiteinde van de centrale draad en de canule. Beide zijn daartoe verbonden met een versterker van het EMG apparaatt. De aktiviteit wordt op de kathodestraalbuis van het EMG apparaat zichtbaar gemaakt en visueel beoordeeld. Verder wordt in toenemende mate van kwantitatieve analyse technieken gebruik gemaakt. Het elektromyogram is geworden tot een veelvuldig gebruikt diagnosticum in de neurologie. In het kader van routine onderzoekingen worden meestal lediemaatspieren onderzocht en slechts zelden de $\mathrm{m}$. sphincter ani externus. Onderzoek van deze spier komt met name in aanmerking bij mictie- en defaecatiestoornissen.

De spieraktiviteit kan ook warden geregistreerd met oppervlakte-elektroden. Daarmee wordt globale aktiviteit geregistreerd uit een groot deel van de spier, bij de $\mathrm{m}$. sphincter ani externus in feite uit de gehele spier. Een ander voordeel is uiteraard dat bij gebruik van oppervlakte-elektroden niet geprikt hoeft te worden. Aktiviteit wan afzonderlijke spiervezels en individuele MUPs is echter op deze wijze niet te verkrijgen. Oppervlakteelektroden lenen zich a.a. wel goed voor reflexstudies. Voor anderzoek van de m. sphincter ani externus is een plugelektrode ontwikkeld die in de anaalopening wordt geplaatst (Floyd en Walls, 1953).

\subsubsection{EMG PARAMETERS}

\section{Basisaktiviteit}

In een dwarsgestreepte spier in rust wordt normaliter geen EMG-aktiviteit geregistreerd. De $\mathrm{m}$. sphincter ani externus en de $\mathrm{m}$. sphincter urethrae externus daarentegen vertonen normaliter vrijwel voortdurend motorunitaktiviteit (MU-aktiviteit), hetgeen samenhangt met hun functie van sluitspieren. Deze spieren ontspannen bij defaecatie en mictie. Direct na inbrengen van de naaldelektrode in de $\mathrm{m}$. sphincter ani externus is er levendige $\mathrm{MU}$ aktiviteit die vervolgens binnen 30 a $60 \mathrm{~s}$ duidelijk afneemt, vooral wanneer onderzochte voldoende ontspannen is. Bij langdurige registraties lukt het soms de spontane 
MU-aktiwteit geheel tot verdwijhen te brengen (Petersen en Franksson, 1955; Basmajian en Spring, 1955; Allert en Jelasic, 1968 en 1970). Wanneer de MU-aktiviteit geheel ontbreekt of binnen 60 s na insertie verdwijnt is er sprake van pathologie (Floyd en Walls, 1953; Chantaine et al. 1966 en 1973).

\section{Spontane spiervezelaktiviteit}

Deze aktiviteit is een teken wan denervatie en gaat dan ook vaak samen met een gereduceerd aanspanningspatroon. Bij langbestaande denervatietoestanden kunmen de afzonderlijke fibrillatiepotentialen complexen vormen op basis van ephaptische transmissie tussen spiervezells. Deze aktiviteit wordt aangeduid als complexe repetitieve ontladingen (syn.: 'bizarre hoogfrequente ontladingen' of 'pseudomyotone ontladingen'). Wanneer er veel spontane MU-aktiviteit is kan het moeilijk of zelfs onmogelijk zijn om vast te stellen of zich daartussen fibrillatiepotentialen bevinden. Men probeert de MU-aktiviteit dan te reduceren door patienten te vragen om te persen als bij defaecatie.

\section{Maximaal aanspanningspatroon}

Om de $\mathrm{m}$. sphincter ani externus verder te laten aanspannen kan men de onderzochte vragen om te doen alsof hij een windje tegenhoudt. Ook door hoesten neemt de aktiviteit toe evenals bij taktiele prikkels (bijv. rectaal toucher). Wanneer de MU-aktiviteit niet toeneemt boven het basisniveau is er sprake van pathologie (Ruskin, 1970; Waylonis en Powers, 1972; Pedersen et al. 1978). Normaliter wordt het patroon zo dicht dat de hele basislijn gevuld is en geen afzonderlijke MUPs kunnen worden herkend. Dit noemt men een interferentiepatroon. Men spreekt van een enkelvoudig patroon als de afzonderlijke MUPs als zodanig te herkennen zijn, terwijl een gemengd patroon een dichtheid van het patroon aanduidt, die gelegen is tussen het enkelvoudig en het interferentiepatroon. Het gemengd patroon kan nog nader worden onderverdeeld, zie tabel 6.1.

\subsubsection{BEVINDINGEN BIJ DIABETICI}

Bradley (1980) vond bij diabetes mellitus zelden spontane spiervezelpotentialen van de bekkenbodemspieren. Vindt men denervatieverschijnselen dan heeft dit volgens Bradley en Sundin (1982) weinig waarde, omdat de bekkenbodemmusculatuur inclusief de sphincters normaal al aan beschadiging ten gevolge van defaecatie zijn blootgesteld. Fagerberg (1969) vond bij onderzoek van de bekkenbodemmusculatuur bij 20 diabetici geen afwijkingen in rust en bij poging tot maximale aanspanning. Waylonis en Powers (1972) vonden daarentegen wel een verminderd aanspanningspatroon in de $\mathrm{m}$. sphincter ani externus bij diabetici.

\subsubsection{VESICO-ANALE-REFLEX (VAR)}

\subsubsection{INLEIDING}

De functie van de blaas en de urethra wordt onderzocht door middel van cystometrie, uroflowmetrie, sphincter elektromyografie (Bradley, 1976), registratie van urethradrukprofiel en gecombineerde urodynamische studies. Deze methoden geven slechts in beperkte mate informatie over de innervatie van de blaas en de urethra.

In 1972 beschreef Bradley voor het eerst dat een respons kon worden waargenomen in de $\mathrm{m}$. sphincter ani externus als reactie op elektrische stimulatie van de blaashals. Deze respons kon worden geregistreerd met behulp van naaldelektroden, ingebracht in het subcutane deel van de $\mathrm{m}$. sphincter ani externus, of met oppervlakte-elektroden gemonteerd in een anale plug. Hij noemde deze techniek 'urethrale elektromyelografie'. Deze methode geeft tot op zekere hoogte informatie over de belangrijkste zenuw van de 
detrusor. In 1974 werd deze methode ook toegepasi bij onderzoek van zenuwen, die be= trekking hebben op het sexuele functioneren (Dick et al. 1974).

\subsubsection{TRAJECT VAN DE VAR}

De sensibele receptoren in de blaashals worden elektrisch gestimuleerd. Via proprioceptieve axonen in de $n$. pelvicus verlopen impulsen via de cauda equina naar hel ruggemerg ter hoogte van S2 tot en met S4. De sensibele axonen synapteren op motorische neuronen van de nucleus pudendus in de voorhoorn. Activatie van deze motorische neuronen wekt impulsen op die verlopen door de motorische vezels van de $\mathrm{n}$. pudendus en leiden tot contractie van de bekkenbodemmusculatuur (peri-urethrale musculatuur en $m$. sphincter ani externus).

De latentietijd van die reflexboog wordt bepaald door de som van de latentietijden van de impulsen in de sensibele axonen van de $n$. pelvicus, de motorische vezels van de $n$. pudendus en de synapstijden in de sacralle grijze stof.

De respons verdween na toediening van $0,25 \%$ tetracaine hydrochloride (pontocaine) in de mucosa van de blaas en urethra (Bradley et al., 1975). Dit wijst erop dat de stimulus sensibele receptoren in de blaasmucosa activeert.

De respons verdween ook na bilaterale blokkade van de $n$. pudendus en na blokkade van de sacrale en lumbale wortels tot $L 4$ door locale anaesthesie. Tevens na parenterale toe passing van barbituraten (Bradlley et al., 1975; Rockswold et al „1976). Men mag hieruit concluderen, dat de prikkels die leiden tot de respons, geregistreerd in de $\mathrm{m}$. sphincter ani externus, lopen vanaf de detrusor en de urethra via de $n$. pelvicus en de cauda equina naar het ruggemerg en van daaruit via de $n$. pudendus naar de $m$. sphincter ani externus en de overige bekkenbodemspieren.

Reflexverbindingen tussen de $n$. pelvicus en de $n$. pudendus werden reeds door Barrington in 1914 bij de kat beschreven. Uitzetting van de blaas praduceert een relaxatie van de $\mathrm{m}$. sphincter urethrae externus. Deze reflex gaat vooraf aan de mictie. De afferente vezels van deze reflex verlopen via de $n$. pelvicus en de efferente vezels via de $n$. pudendus. (Zie blz.. 29, reflex nr. 5).

Op grond van doorsnijdingsproeven op laag thoracaal niveau werd deze reflex door Barrington gezien als een segmentale reflex met een centrum in het sacrale merg.

Denny-Brown en Robertson (1933) beschreven bij de mens een reciproke relatie tussen de innervatie van de $\mathrm{m}$. detrusor enerzijds en de $\mathrm{m}$. sphincter ani externus en m. sphincter urethrae externus anderzijds. Zij merkten op dat bij vulling van de blaas de rustionus van beide sphincters toenam tot net voor de mictie. Dan stopt het aanspanningspatroon vrij plotseling. Ook dit pleit voor een segmentale reflex tussen de n. pelvicus en de n. pudendus.

Bradley en Teague (1972) demonstreerden door stimullatie van de n. pudendus bil de kat een directe reflexverbinding tussen de $n$. pudendus en de $n$. pelvicus. Deze respons verdween na toediening van pentobarbital, wat pleit voor een segmentale reflex. De latentietijd van deze respons was $7=10 \mathrm{~ms}$.

Ook de latentietijd van de VAR, die bij normale individuen ligt tussen 50 en $80 \mathrm{~ms}$ (Bradley, 1972; Vereecken et al., 1981) past bij een segmentale reflex met waarschijnlijk multipelle synapsen in het ruggemerg.

Vereecken et al. (1981) waren van mening, dat de reflex polysynaptisch van aard was, omdat bij toename van de amplitudo of duur van de stimulus de latentietijd van de reflex werd verkort en de duur en de amplitudo toenamen. Een enkele keer merkten zij op dat de latentietijd korter werd, zelfs gedurende stimuli met dezelfde intensiteit of bij een combinatie van twee stimuli. De twerede reden om aan een polysynaptische reflex te denken was de lange latentietijd van de reflex (tot $80 \mathrm{~ms}$ ). Gezien de geleidingssnelheid en lengte van de betreffende reflexboog zou een kortere latentietijd te verwachten zijn indien die reflex oligosynaptisch verliep. 


\subsubsection{WIJZE VAN UITVOERING VAN DE VAR}

Om het proximale deel van de urethra te stimuleren gebruikten Bradley (1972). Andersen en Bradley (1976), Rockswold en Bradley (1977) en Vereecken et al. (1981) een Foley katheter met een diameter van 10 tot 22 French, waarop oppervlakte-elektroden waren gemonteerd. Nadat de katheter was ingebracht werd de ballon gevuld met fysiologisch zout, waarna de katheter werd teruggetrokken totdat de ballon vastzat in de blaashals. De elektroden kwamen hierdoor in contact met de mucosa van het proximale deel van de urethra. Bradley (1972) bracht de elektroden ook in contact met de blaaswand, nadat hij de ballon geledigd had.

Bradley (1972), Rockswold en Bradley (1977) en Vereecken et all. (1981) gebruikten 16 tot 64 blokprikkels met een duur variërend van 0,1 tot soms $200 \mathrm{~ms}$, een amplitudo van 4 tot $30 \mathrm{~V}$ en stimuleerden over het algemeen met variërende intervallen van 5 tot $20 \mathrm{~s}$. Vereecken al (1981) stimuleerden met toenemende amplitudo en duur tot een maximale respons werd verkregen. Alleen responsen na supramaximale stimulatie en responsen die reproduceerbaar waren werden geaccepteerd. De prikkeldrempel bleef meestal beneden de pilindrempel.

De afleiding van het reflexantwoord vond plaats via oppervlakte-elektroden in een anale plug (Bradley, 1972; Rockswold en Bradley, 1977) of door middel van een concentrische naaldelektrode ingebracht in de $\mathrm{m}$. sphincter ani externus (Vereecken et al., 1981).

Om van de $\mathrm{m}$. sphincter ani externus een eenduidige respons te verkrijgen dient over het algemeen meerdere malen te worden gestimuleerd, waarbili de middels naaldelektrode of anale plugelektrode verkregen respons wordt uitgemiddeld (Bradley, 1972; Vereecken et al., 1981) of gesuperponeerd (Vereecken ett al., 1981).

\subsubsection{VAR PARAMETERS}

Bradley (1972) vond dat de duur en amplitudo van de VAR variabel waren intraindividueel. De amplitudo varieerde bij supramaximale stimulatie van 25 tot $150 \mathrm{uV}$. De respons was het gemakkelijkst op te wekken als de blaas leeg was. De latentietijd en amplitudo waren gelijk bij stimulatie van de blaaskoepel of de blaashals (Andersen en Bradley, 4976).

Vereecken et al. (1981) vonden in $89 \%$ van de onderzochten dat de duur van de respons bij volle blaas afnam. Hij nam ook waar, dat de amplitudo enigszins lager was bij een volle bllaas, mogelijk ten gevolge van een inhibitie van de detrusor via efferenten van de $\mathrm{n}$. hypogastricus (Langworthy et all., 1934). De latentietijd van de reflex nam af bij toename van de intensiteit en de duur van de stimulus, terwijl de duur en amplitudo van de respons toenamen tot een maximale waarde. De duur van de respons varieerde van 150 tot $900 \mathrm{~ms}$.

Bradley (1972) vond dat poging tot relaxatie van de bekkenbodemmusculatuur de reflex normaliter doet verdwijnen. Bij laesies van de corticospinale banen (cerebrovasculaire accidenten, multiple slcerose) bleek de reflex te persisteren.

Yalla et al.(1978) en Vereecken et al. (1981) vonden, dat slechts een gering aantal normale mensen erin slaagt de VAR te laten verdwijnen.

Bij urodynamisch ondlerzoek vond Bradley (1972) dat het optreden van de detrusorreflex gepaard ging met verdwijning van de motorunitactiviteit in de $\mathrm{m}$. sphincter urethrae externus. Tegelijkertijd was er een toename van de latentietijd en een vermindering van de amplitudo van de VAR. Bij een maximale intravesicale druk verdween de VAR totaal doch verscheen weer als de detrusorreflex afnam.

Bradley (1976) vond bij $57 \%$ van de onderzochte patienten met een detrusorsphincterdyssynergie (zowel bij detrusorhyperreflexie als -arefexie) een toegenomen latientietijd van de VAR. 
In tabel 4.1 wordt een overzicht gegeven van de normaalwaarden van de VAA bij registratie uit de m. sphincter ani externus in de ons beschikbare literatuur.

Tabel 4.1

Literatuuroverzicht referentiewaarden VAR bij registratie uit de $m$. sphincter ani externus

Bradley 1975

Rockswold et al. 1976

Vereecken et al. $1981(50)$

Fidas et al. 1985 (15)

$$
\begin{array}{r}
50-80 \mathrm{~ms} \\
60-80 \mathrm{~ms} \\
55-80 \mathrm{~ms} \\
80 \mathrm{~ms}
\end{array}
$$

\subsubsection{KLINISCHE TOEPASSING}

De VAR geeft informatie over de geleiding van prikkels in zijn traject. Men kan de mate waarin de geleiding is gestoord volgen, bijvoorbeeld bij chronische arachnoiditis, trauma, tumor of andere laesies in het gebled van de cauda equina.

Rockswold et al. (1976) beschreven twee patienten met een normaal caudogram en een abnormale VAR. Deze patienten bleken bij operatie een tumor distaal van de durazak te bezitten. Zij vonden tevens dat een afwezige VAR steeds gecorreleerd was met een onvermogen tot mictie met als gevolg een retentie. Er was dan altijd bij operatie een anatomisch substraat aanwezig. Een vertraagde respons was niet altijal verbonden met urineretentie en een peroperatief aantoonbaar anatomisch substraat.

Een normale VAR wil volgens Rockswold et al. (1976) zeggen dat de innervatie naar de blaas vanuit het sacrale ruggemerg intact is. Dit wordt gesteund door het feit, dat de detrusorreflex steeds intact is, zelfs in geval van een ruggemerglaesie. Een normale respons sluit geen pathologie van de cauda equina uit.

Gerstenberg et al. (1984) trachtten door registratie van de latentietijd van de VAR onderscheid te maken tussen een neurogeen en een niet neurogeen lijden bij patienten met een prostaathypertrofie en een detrusorhyperreflexie van de blaas. Zij registreerden de VAR tijdens het cystometrisch onderzoek op het moment van een detrusorcontractie zowel bij patienten met een aangespannen als een ontspannen $\mathrm{m}$. sphincter urethrae ex termus.

Bij de patienten met prostaathypertrofie zonder neurologische afwijkingen kon de VAR niet worden geregistreerd tijdens een willekeurige detrusorcontractie en een ontspannen m. sphincter urethrae externus. Wel kon een respons worden opgewekt bij een willekeurig aanspannen van de $\mathrm{m}$. sphincter urethrae externus.

Bij de patienten met een combinatie van prostaathypertrofie en een centraal neurogeen lijden (normal pressure hydrocephalus) kon de VAR alleen worden geregistreerd bij een niet willekeurige detrusorcontractie en een ontspannen $\mathrm{m}$. sphincter urethrae externus. Het resultaat van de prostaatoperatie bij de patienten uit de eerste groep was goed, dit in tegenstelling tot het resultaat bij de patienten uit de tweede groep.

Kimche ef al. (1985) vonden bij de door hen onderzochte patienten met een benigne prostaathypertrofie en een hyperreflexie van de blaas, die niet verdween na een resectie, een VAR met een latentietijd korter dan $60 \mathrm{~ms}$.

Door middel van het onderzoek van de latentietijd van de VAR trachtten zij het postoperatieve resultaat te voorspellen.

Andersen en Bradley (1976) vonden een VAR bepaald met naaldelektroden geregistreerd uit de $\mathrm{m}$. sphincter ani externus bij 20 van de 27 onderzochte diabetici. De spreiding van de latentietijden varieerde van 60 tot $120 \mathrm{~ms}$. Bij 7 patienten was het antwoord niet opwekbaar. 


\subsubsection{INLEDING}

De bulbocavernosusreflex $(\mathrm{BCR})$ is nauw verbonden met functies van de tractus urogenitalis. Innervatiestoornissen van deze tractus kunnen gepaard gaan met ałwijkingen van deze reflex (Lapides en Bobbith, 1956; Bors en Blinn, 1957).

De klassieke manier om een BCR op te wekken is te knijpen in de glans penis. De contractie van de $\mathrm{m}$. bulbocavernosus kan dan worden gevoeld door palpatie achter het scrotum op de middenlijn van de $\mathrm{m}$. bulbocavernosus. Het is vaak moeilijk om de contractie van de spier goed te voelen. In plaats daarvan palpeerden Lapides en Bobbith (1956) de contractie van de $\mathrm{m}$. sphincter ani externus via rectaal toucher.

Het onderzoek van deze reflex is belangrijk voor het bepalen van laesies op het niveau $\mathrm{S} 2$ tot en met $\mathrm{S} 4$ en de afferente en efferente verbindingen.

Rushworth (1967) stimuleerde de glans penis door middel van elektrische stimuli en vond dat de reflex bil] registratie uit de $\mathrm{m}$. bulbocavernosus zeer stabiel was, zonder uitdoving door gewenning. Hij vond een latentietijd van $30-40 \mathrm{~ms}$. Bovendien constateerde hij dat de reflex bij alle normale mannen aan beide zijden van de penis kon worden opgewekt en de latentietijd gellijk was.

Ertekin en Reel (1976) stimuleerden de glans penis en registreerden een stabiele respons uit de $\mathrm{m}$. bulbocavernosus met een gemiddelde latentietijd van $36,1 \mathrm{~ms}$. Bij stimulatie van het proximale deel van de penis bleek de reflex ook zeer stabiel te zijn echter met een kortere latentietijd ( $\pm 27 \mathrm{~ms}$ ). De registratie van de reflex uit de $\mathrm{m}$. sphincter anil externus gelukte slechts bij $21 \%$ van de gezonde mannen. Deze reflex was volgens deze schrijvers weinig stabiel, de reflexdrempel was hoger dan voor de $\mathrm{m}$. bulbocavernosus en de latentietijd varieerde van 35 tot $100 \mathrm{~ms}$. Bij supranucleaire laesies vonden zij een niet veranderde latentiet ijd, imaar een toegenomen duur van de respons uit de $\mathrm{m}$. bulbocavernosus, vaak met na-ontladingen. De latentietijd van de BCR werd o.a. ook onderzocht door Vodusek en Lachman (1977), Siroky et al. (1978), Vignoli (1978), Haldeman et all. (1982) en Vodusek et al. (1983). De reflex was volgens deze schrijvers zeer stabiel, zowel bij afleiding uit de $\mathrm{m}$. sphincter ani externus als uit de $\mathrm{m}$. bulbocavernosus.

Pedersen et al. (1982), Swash (1982) en Vodusek et al. (1983) meldden dat de anaalreflex, die evenals de BCR verloopt via de sacrale segmenten "na perianale stimulatie en bij registratie uit de $\mathrm{m}$. sphincter ani externus uit meerdere componenten bestaat.

Swash (1982) vond een eerste component na 6 - 13 ms (gemiddeld 9,3). Een tweede na 23 - $45 \mathrm{~ms}$ (gemiddeld 33,2 ) en een derde ongeveer $5 \mathrm{~ms}$ later.

Vodusek et al. (1983) beschreven vier componenten bij registratie uit de $\mathrm{m}$. sphincter ani externus. Een eerste en tweede component na perineale en soms perianale stimulatie (respectievelijk na 5 en 13 ms). Deze waren stabiel, toonden geen uitdoving door gewenning en bleven aanwezig na epidurale anaesthesie.

De derde component (na ca. $33 \mathrm{~ms}$ ) werd bij alle onderzochte mannen en vrouwen gevonden na stimulatie van de $\mathrm{n}$. dorsalis penis of $\mathrm{n}$. clitoridis en de vierde component bij perianale stimulatie na $55 \mathrm{~ms}$. Deze vierde respons neigde wel tot uitdoving door gewenning.

\subsubsection{TRAJECT VAN DE BCR}

Sensibele impulsen verlopen via sensibele vezels van de $n$. dorsalis penis of $n$. clitoridis door de cauda equina naar het ruggemerg ter hoogte van $\mathrm{S} 2 t / \mathrm{m} S 4$. De sensibele axonen synapteren op motorische neuronen in de nucleus pudendus evenals bij de VAR. Activatie van deze motorische neuronen wekt impulsen op die verlopen door de motorische vezels van de $n$. pudendus en leiden tot contractie van de $\mathrm{m}$. sphincter ani externus en overige bekkenbodemmusculatuur. De latentietijd door de reflexboog wordt bepaald 
door de som van de latentietijden van de impuisen in de sensibele axonen van de $\mathrm{n}$. pudendus of $\mathrm{n}$. clitoridis, de motorische vezels van de $\mathrm{n}$. pudendus en de synapstijden in de sacrale grijze stof.

Wat betreft de anatomische en fysiologische segmentale circuits is er een overlapping be treffende urologische en sexuele functies. Deze overlapping is zowel experimenteel als door klinische observaties aangetoond. De nuclei voor de urologische en sexuele functies liggen dicht bij elkaar in het sacrale merg (Bors en Comarr, 1960; Yalla et al. 1978). Suprasegmentale facilitatie en inhibitie verlopen zeer complex en werden reeds eerder beschreven in hoofdstuk 2 .

Pedersen et al. (1978) vermeldden dat de contractie van de $\mathrm{m}$. sphincter ani externus na perianale stimulatie bij gezonde mensen ook optreedt bij het opwekken van de flexorreflex door stimulatie van de $n$. tibialis. Dit betekent dat ook de eerste en tweede sacrale ruggemergswortels deelnemen aan de reflex.

Yalla et al. (1978) vonden dat na i.v. toediening van 5 mgr diazepam een hogere prikkelsterkte nodig was om een reflexantwoord in de $\mathrm{m}$. sphincter urethrae externus op te wekken. Deze verandering werd niet opgemerkt bij een lagere dosering.

Vignoli (1978) vond geen verandering in de benodigde prikkelsterkte na toediening van zelfs 10 mgr diazepam i.v.

Bij unilaterale stimulatie van de $n$. dorsalis penis werd in beide delen van de $m$. sphincter ani externus en beide $\mathrm{mm}$. bulbocavernosi een respons geregistreerd, meestal met een verschil van ongeveer $2 \mathrm{~ms}$. Kennelijk verloopt de reflex ten dele via kruisende vezels in het sacrale merg (Siroky et al., 1979).

Volgens Ertekin en Reell (1976) behoren de afferente vezels van de $\mathrm{n}$. pudendus van de BCR op basis van de geleidingssnelheid tot de A-delta groep. Bors en Comarr (1971) en Yalla et al. (1978) vinden dat deze vezels tot de A-alfa groep behoren en Vodusek et al. (1982) tot de A-beta groep. De efferente vezels van de BCR behoren volgens Bors en Comarr (1971) en Yalla et al. (1978) tot de A-alfa groep.

Wat betreft het aantal synapsen vonden Vereecken et al. (1981) het waarschijnlijk dat de $\mathrm{BCR}$ een oligosynaptische reflex is op grond van de korte latentietijden.

Trontelj en Trontell (1978) vonden duidelijke aanwijzingen voor het polysynaptische karakter van de reflex. Zij vonden namelijk dat de latentietijd aanzienlijk verminderde bij toename van de intensiteit van de stimuli. Dit is kenmerkend voor een polysynaptische reflex. Swash (1982) meldde op grond wan zijn onderzoek , dat er oligosynaptische en polysynaptische componenten waren.

\subsubsection{WIJZE VAN UITVOERING VAN DE BCR}

Stimulatie van de $n$. dorsalis penis wordt meestal verricht door middel van twee ringelektroden aangebracht rond respectievelijk de corona van de glans en de schacht van de penis met een onderlinge afstand van ongeveer $1 \mathrm{~cm}$ (Ertekin en Reel, 1976; Vacek en Lachman, 1977; Siroky et al., 1978; Vignoli, 1978; Yalla et al., 1978; Vereecken et al., 1981 en Haldeman et al., 1981).

Vodusek et al. (1983) stimuleerden de $\mathrm{n}$. dorsalis penis en $\mathrm{n}$. clitoridis door middel van twee oppervlakte-elektroden met een onderlinge afstand van ongeveer $2 \mathrm{~cm}$. De proximale elektrode was bij alle gebruikte oppervlakte-elektroden verbonden met de kathode van de stimulator.

Het aantal elektrische stimuli door bovengenoemde schrijvers toegediend varieerde van enkele tot ongeveer 100. De stimuli hadden in het algemeen een frequentie van 1 tot 
$1,5 \mathrm{~Hz}$, een sterkte van $50-500 \mathrm{~V}$ en een duur variërend van 0,1 tol $0,5 \mathrm{~ms}$. De intensiteit van de elektrische stimuli werd meestal geleidelijk verhoogd tot het tolerantieniveau werd bereikt. Dil was in het algemeen 2,5 maal de gevoelsdrempel $(80-150 \mathrm{~V})$.

Vignoli (1978), Vereecken et al. (1981) en Vodusek et al. (1983) accepteerden alleen responsen na supramaximale stimulatie en responsen die tenminste $2 \times$ reproduceerbaar waren.

Bij patienten met een laesie van de cauda equina waren prikkels nodig met een duur van 0,5 tot $1 \mathrm{~ms}$ en een sterkte tot $500 \mathrm{~V}$. Soms waren ook stimulustreinen noodzakelijk om een reproduceerbare respons te verkrijgen.

De afleiding van het reflexantwoord vond plaats via concentrische naaldelektroden ingebracht in de $\mathrm{m}$. sphincter ani externus of in de $\mathrm{m}$. bulbocavernosus (Ertekin en Reel, 1976; Vignoli, 1978; Vereecken et al., 1981) of via elektroden in een analle plug (Haldeman et al., 1982).

Siroky et al. (1978) vonden dat een goed reproduceerbare respons gemakkelijker te registreren was uit de $\mathrm{m}$. bulbocavernosus dan uit de $\mathrm{m}$. sphincter ani externus.

Om te bevestigen dat de elektrode in de $\mathrm{m}$. bulbocavernosus zit is het nodig aanspanning van de spier te verkrijgen door bijv. te kuchen of licht te knijpen in de glans penis (Ertekin en Reel, 1976).

De bandbreedte van de versterker ligt in het algemeen tussen 5 en $250 \mathrm{~Hz}$. Ter verkrijging van een eenduidige respons werd gebruik gemaakt van middelingstechnieken en superpositie (Vereecken et al.., 1981).

\subsubsection{BCR PARAMETERS}

De klassieke BCR komt overeen met de derde component van de anaalreflex, is vrii stabiel en toont geen uitdoving door gewenning (Vodusek et al., 1983). De vorm is enkelvoudig tot polyfasisch. Soms bestaat deze derde component uit enkele subcomponenten. Deze derde component is gemakkelijk te onderscheiden van het licht enkelvoudige achtergrondpatroon zoals dat meestal in de $\mathrm{m}$. sphincter anl externus in rust wordt gezien. De derde component van de anaalreflex komt overeen met de eerste component van de BCR (Vodusek et al., 1983).

De klassieke BCR heeft dezelfde vorm zowel bij registratie uit de $\mathrm{m}$. bulbocavernosus als uit de $\mathrm{m}$. sphincter ani externus. De duur van deze respons is variabel en in de regel korter dan de VAR. Vereecken et al. (1981) vonden een duur van 10 tot $40 \mathrm{~ms}$.

De eerste verschijning van de respons na geleidelijk opvoeren van de prikkelsterkte heeft niet de kortste latentietijd. De latentietijd wordt korter en de amplitudo groter (Siroky et al. 1978) bij een toenemende intensiteit.

Haldeman et al. (1982) onderzochten de vorm van de respons en vonden hoe later de respons optrad, hoe minder polyfasisch deze werd. Bovendien werd de amplitudo lager en de duur korter. Blaasvulling had volgens Vereecken et al. (1981) geen invloed op de $\mathrm{BCR}$.

De stimulusintensiteit, om de eerder beschreven vierde component na peri-anale stimulatie te registreren, is wisselend, doch in de meeste gevallen hoger en onaangenamer dan voor de derde component (Vodusek et $\mathrm{al}_{\mathrm{n}}$, 1983). Ook de duur van deze component is langer dan de derde component. Deze vierde component van de anaalreflex komt overeen met de tweede component van de BCR (Vodusek et al., 1983).

In tabel 4.2 wordt een overzicht gegeven van de door de verschillende onderzoekers bepaalde normaalwaarden van de latentietijden van de BCR I na stimulatie van de $n$. dorsalis penis of $n$. clitoridis en bij afleiden uit de m. sphincter ani externus en de $\mathrm{m}$. bulbocavernosus. 
Literatuuroverzicht referentiewaarden $B C R$ bij registratie uit de $m$. sphincter ani externus

$\begin{array}{llr}\text { Ertekin en Reel } 1976(3) & 35-100 \mathrm{~ms} \\ \text { Vignoli 1978 (10) } & 45 & \mathrm{~ms} \\ \text { Vereecken et al. } 1981(50) & 30-45 \mathrm{~ms} \\ \text { Vodusek et al. } 1983(14) & 28-44 \mathrm{~ms} \\ \text { Fidas } 1985(15) & 50 & \mathrm{~ms}\end{array}$

\subsubsection{KLINISCHE TOEPASSING}

Vacek en Lachman (1977), Siroky et al. (1978), Haldeman et al. (1982) en Ertekin et all. (1985) bepaalden de latentietijd van de BCR bij afleiding uit de $\mathrm{m}$. bulbocavernosus bij diabetici met een erectiestoornis. Voor een overzicht van deze gegevens zie tabel 4.3 .

Tabel 4.3

Literatuuroverzicht latentietijd BCR bij patienten met diabetes mellitus met een erectiestoornis

$\begin{array}{llll}\text { Vacek en Lachman 1977 (20) } & 45,8 & \mathrm{~ms} & \text { (SD 4,3) } \\ \text { Siroky et al. 1978 (4) } & 46-75 \mathrm{~ms} & \\ \text { Haldeman et al. 1982 (1) } & 68 & \mathrm{~ms} & \text { (oppervlakte-electrode) } \\ \text { Ertekin et al. 1985 (20) } & 47,2 & \mathrm{~ms} & \text { (SD 2,9) }\end{array}$

Ertekin en Reel (1976) vonden dat de latentietijd van de reflex ook verlengd was bi] aicoholici.

Ertekin en Reel (1976) vonden in tegenstelling tot Yalla et al. (1978) dat bij patienten met psychogene impotentie de reflex ondlerdrukt kon worden. Zij vonden ook dat de duur van de responsen bij centrale laesies verlengd was en dat zij bestonden uit meerdere polyfasische complexen. Zij maakten melding van na-ontladingen.

\subsubsection{TIBIALIS/PUDENDUS/PELVICUS (HYPOGASTRICUS) EVOKED POTENTIALS}

\subsubsection{INLEIDING}

Met somato-sensory evoked potentials (SSEP) worden die potentialen bedoeld die worden opgewekt na stimulatie van de perifere zenuwen, de huid of de mucosa met hun sensibele receptoren. Deze potentialen kunnen afgelleild worden van het ruggemerg, de hersenstam en het cerebrum. De respons van het cerebrum op stimulatie van sensibele receptoren en vrije zenuwuiteinden gaat verloren in de achtergrondactiviteit van het spontane elektro-encephalogram.

Er zijn verschillende wormen van stimulatie mogeliijk.

Met de dermatoomstimulatie kan men afwijkingen in de achterwortel en het ruggemerg vaststellen. Bij stimulatie van een perifere zenuw kunnen via de SSEP ook afwijkingen in de zenuw zelf worden vastgesteld maar over het algemeen wordt hiervoor het klassieke zenuwgeleidingsonderzoek gebruikt. 
Dawson (1947) was de eerste die door middel van fotografische superpositie een reproduceerbare evoked potential zichtbaar maakte. Vervolgens werden middelingstechnieken onitwikkeld met behulp van analoge en digitale computers (Dawson, 1950; Barlow, 1957; Desmedi en Noël, 1973).

De cerebrale somato-sensory evoked potential is samengesteld uit twee componenten. Het eerste deel is het specifieke complex en bestaat uit een volumegeleide positieve thalamo-corticale reactie (witte en dan grijze stof of somato-sensibele schors). Dit is het eerste teken van aankomst van de afferente prikkels in de parietale schors. Het tweedie deel is het aspecifieke complex en kan beschouwd worden als een diffuse corticale reactie ('grijze stof reactie').

De SSEP, en dan met name het specifieke complex hiervan, kan in de kliniek gebruikt worden voor onderzoek van het perifere zenuwstelsel (polyneuropathie) en voor onderzoek van het gemyeliniseerde systeem van het centrale zenuwstelsel. Voor onderzoek van de corticale functies dient vooral het aspecifieke deel van het complex. Diffuse veranderingen van het aspecifieke deel van de SSEP komen voor bij intoxicaties ten gevolge van barbituraten, bij neurolipidose en bij comata.

\subsubsection{TRAJECT VAN DE TIBIALIS/PUDENDUS/PELVICUS (HYPOGASTRICUS) EVOKED POTENTIALS}

De door de toegediende stimuli ontstane actiepotentialen worden voortgeleid naar het spinale ganglion en vervolgens naar de achterhoorn. Alleen dikkere neuronen worden gestimuleerd. Actiepotentialen van de vezels van een zuiver sensibele zenuw of dermatoom vormen samen de 'sensory nerve action potential" (SNAP). De amplitudo van de SNAP wordt lager en de duur langer naarmate de afstand tussen de plaats van de stimulus en de registratie toeneemt. Dit komt door het verschill in geleidingssnellheid van de afzonderlijke vezells.

Stimuli vanuit de $\mathrm{n}$. tibialis worden geleid via de ruggemergswortels (L5,) S1 en S2 om daarna via het meest mediale deel van de achterstreng, de tractus gracillis, in het ruggemerg op te stijgen. Stimuli vanuit de $n$. pudendus en $n$. pelvicus worden geleid via ruggemergswortels S3 en S4 en stimuli vanuit de $n$. hypogastricus via de wortels Th12 en L1. Ook deze stimuli stijgen op via de achterstreng.

Ter hoogte van de hersenstam wordt de informatie via een synaps in de achterstrengkernen overgedragen naar de lemniscus medialis aan de gekruiste zijde en vervolgens naar de thalamus. Dit is het tweede neuron. Het derde neuron brengt informatie over van de nucleus ventro-lateralis van de thallamus naar de specifieke sensorische cortex. $O p$ de verdere verwerking van prikkels op corticaal niveau wordt in het kader van dit onderzoek niet nader ingegaan.

Sterke aanwijzingen voor de hierboven beschreven geleiding van de somato-sensory evoked potential via het achterstreng/lemniscus systeem werden gevonden in klinische studies, waarbij afwijkende somato-sensory evoked potentials werden gevonden bij patienten met symptomen die behoren bij een laesie van dit systeem. Deze werden niet glevonden bij patienten met een sensibiliteitsstoornis ten gevolge van een laesie van de tractus spinothalamicus. Ook bij doorsnijding van de tractus spinothalamicus (Namerow, 1968) blijft de geleiding van de somato-sensory evoked potential intact (Cusick et al., 1979).

Overigens zijn de inzichten in de verdeling van de functie tussen de achterstrengen en overige baansystemen in het ruggemerg aan verandering onderhevig (Wall, 1970; Sarnowski et al., 1975; Schneider et al., 1977).

Samenvattend zijn er overtuigende aanwijzingen dat geleiding bij de mens via de achterstreng verloopt. 
Voor het opwekken van somato-sensory evoked potentials kunnen zowel mechanische als elektrische stimuli worden toegepast. De intensiteit van mechanische slimuli is moeilijk te kwantificeren. Daarom wordt voor de klinische diagnostiek uitsluitend elektrische stimulatie toegepast door middel van kortdurende rechthoekprikkels met een constante stroomsterkte. Gebruikt worden prikkels van ongeveer $0,2 \mathrm{~ms}$ duur en 100 tot $200 \mathrm{~V}$. De prikkelsterkte is net boven de gevoelsdrempel of goed voelbaar, maar niet pijnlijk.

Als stimulatie-elektroden komen zowel oppervlakte-elektroden als naaldelektroden in aanmerking. Bil het plaatsen van de elektroden dient men zich te realiseren dat de feitelijke zenuwdepolarisatie onder de kathode plaatsvindt. De stimulusherhalingsfrequentie wordt bepaald door de vraag welk deel van de evoked potential men wil bestuderen: het specifieke complex (de vroege componenten) of het aspecifieke complex (de late componenten).

Voor het opwekken van de vroege componenten kunnen hogere stimulusfrequenties tot ongeveer $10 \mathrm{~Hz}$ worden gebruikt. Bij hogere frequenties treedt een geleidelijke toename in latentietijd en afname in de amplitudo op van verschillende componenten.

Voor de late componenten is een lagere herhalingsfrequentie met niet-periodieke stimulatie van ongeveer $0,2 \mathrm{~Hz}$ nodig. De herstelfase van de late componenten is lang (meer dan $3 \mathrm{~s}$ ). Bij snellere frequentie ontstaat uitdoving door gewenning (habituatie).

De $\mathrm{n}$. tibialis wordt meestal gestimuleerd achter de mediale malleolus (Jones en Small, 1978; Eisen en Elleker, 1980; Haldeman et al., 1982) of in de knieholte (Tsumoto et al., 1972; Trojaborg en Petersen, 1979). Dit gebeurt met blokprikkels van 0,1-0,3 ms duur, 100 tot $200 \mathrm{~V}$ (beneden de pijndrempeil) en met een frequentie van $2-5 \mathrm{~Hz}$.

De kathode werd steeds ongeveer $2 \mathrm{~cm}$ proximaal van de anode geplaatst.

Haldeman et al. (1982) stimuleerden de $n$. dorsalis penis door middel van twee ringelektroden aangebracht respectievelijk rond de corona van de glans en de schacht van de penis met een vaste onderlinge afstand van $1 \mathrm{~cm}$.

De n. clitoridis stimuleerden zij door middel van een kathode tegen de clitoris en een anode op $1 \mathrm{~cm}$ van de kathode tussen de labia minores.

Het aantal toegediende prikkels, duur en intensiteit zijn hetzelfde als bij stimulatie van de n. tibialis.

Badr et al. (1982 en 1984) stimuleerden de n. pelvicus met elektroden die via een cystoscoop ter plaatse van de achterziijde van de blaaswand werden gebracht. Volgens Badr et al (1982) worden zowel de afferenten van de $n$. pelvicus als van $n$. hypogastricus gestimuleerd. Bij bipolaire stimulatie was de afstand tussen de elektroden $1 \mathrm{~cm}$. Bij monopolaire stimulatie werd een indifferente elektrode op de dij geplaatst.

De stimulatie vond plaats met rechthoekprikkels van 0,5 ms duur, een sterkte van 100 . $200 \mathrm{~V}$ ' (beneden de pijndrempel) en een frequentie van $1,8 \mathrm{~Hz}$. Deze stimuli werden nietperiodiek toegediend.

Een SSEP kan zowel spinaal als corticaal worden geregistreerd. De spinale sensibele potentiaal wordt nabij of op de wervelkolom geregistreerd en de corticale op de hoofdhuid. Localisatie van de elektroden op het hoofd van de patient gebeurt volgens het internationale $10-20$ systeem.

Haldeman et al. (1982) en Badr et al. (1982) plaatsten de actieve elektrode bij hun onderzoek op verschillende plaatsen op de schedel. Bij een positie in de middellijn $2 \mathrm{~cm}$ achter $\mathrm{Cz}$ (elektrodepositie Cz') werd de beste SSEP van de n. tibialis (TEP), n. pudendus of clitoridis (PEP) en $n$. pelvicus (hypogastricus) (PHEP) geregistreerd. De referentieelektrode plaatsten zij ter plaatse van $\mathrm{Fz}$. De aardelektrode werd geplaatst op $\mathrm{Pz}$.

Wat betreft de instrumentatie wordt gebruik gemaakt van een stimulator, versterkers, een averager $r_{y}$ een ascilloscoop en een systeem voor het vastleggen van de evoked potentials. De versterkers zijn differentiaal versterkers met als algemeen kenmerk een hoge ingangsimpedantie en rejectiefactor en een laag ruisniveau. 
De fifterstainden hebben een aanzienlifke invloed op de latentietijden. Laagdoorlaafiltering veroorzaakt met afnemende afsniffrequentie een toename in de latentieMijen.

De gewernste bandbreedte van de versterker bij registratie van de corticale SSEP ligt gewoonlikk tussen 3 en $1600 \mathrm{~Hz}$ (De Weerd 1981 ; Haldeman et al, 1982; Vredeveld, 1985). Voor het specifieke complex is volgens de literatuuropgaven middeling van 500 tot 1000 responsen voldoende (Colon et al., 1983). Voor het aspecifieke complex voldoet middeling van 100 responsen. Vaak kan echter ook met minder volstaan worden.

Om de reproduceerbaarheid te controleren is het nodig de meting te herhalen. Stimulatie artefacten kunnen de beoordeelbaarheid van de respons bemoeilijken, maar kunnen bij een goede technische uitwoering doorgaans voldoende worden vermeden.

Om de mate van artefactwermenging te kunnen beoordelen, wordt een stuk registratie voorafigaande aan de stimulus meegemiddeld (pre-stimulus interval). Dit pre-stimulus interval bedraagt over het algemeen 20 tot $30 \%$ van de analysetijd. Verder kan de betrouwbaarheid worden vergroot door gebruik te maken van een 'dummy"-meting. Deze meting verloopt volgens het normale evoked potential protocol, doch er worden geen stimuli toegediend. Na het middelen moet dan een vrijwel vlakke basislijn overblijven.

Spierbewegingsartefacten kunnen de kwaliteit van de registratie ongunstig beïnvloeden. Een comfortabele houding vermindert de artefacten van de nekspieren. De spierartefacten in de temporaalstreek worden gunstig beinvloed door het in lichte mate openen van de mond. De oogartefacten evenals de artefacten dqor het alfa-ritme van het EEG, worden verminderd door de patient te vragen zijin ogen te openen en te fixeren op een bepaald punt dat niet te dichtbij is.

Storend kunnen ook zijn de elektrische of magnetische invloeden van radiologische, chirurgische of fysiotherapeutische afdelingen.

Stimulatie van perifere zenuwen kan ook somato-motorische responsen uitlokken. Deze myogene potentialen hebben latentietijden variërend van 15 tot $100 \mathrm{~ms}$ en kunnen interfe. reren met de SSEP. Deze responsen kumnen worden verminderd door relaxatie (Colon et al., 1983).

De temperatuur heeft invloed op alle zenuwgeleidingen en daarmee op de latentie van de SSEP. De geleidingssnelheid neemt af met ongeveer $2 \mathrm{~m} / \mathrm{s}$ per ${ }^{\circ} \mathrm{C}$. Verwarmen van de extremiteiten kan nodig zijn om de gewenste temperatuur (boven de $30^{\circ} \mathrm{C}$.) te verkrijgen.

De meting wordt meestal verricht door middel van een elektronische 'marker'. Deze geeft een tijdsmarkering op het oscilloscoopscherm. Hierdoor kunnen latentietijden direct vanaf het oscilloscoopscherm worden bepaald.

De identificatie van de verschillende evoked potential componenten geschiedt op basis van pollariteit en de gemeten latentietijden van de toppen.

\subsubsection{CONFIGURATIE EN LATENTIETIJDEN VAN DE SSEP}

De van de schedel afgeleide SSEP bestaat uit een aantal positieve en negatieve toppen. De configuratie van de SSEP is sterk afhankelijk van de elektrodenplaatsing. Wordt de referentie-elektrode niet op de schedel geplaatst dan treden veel far-field potentials op. In deze studie zal alleen aandacht worden besteed aan onderzoeken waarbij de referentie-elektrode op de schedel werd geplaatst. Ook dan worden nog voor verschillende toppen verschillende waarden opgegeven in de literatuur (Tsumoto et al., 1972; Jones en Small, 1978; Eisen en Elleker, 1980).

De corticale SSEP bestaat uit twee verschilliende delen. Het specifieke en het aspecifieke complex.

Het specifieke gedeelte van de corticale respons heeft de hoogste amplitudo op dát deel van de schedel dat ligt boven de specifieke projectie van het gestimuleerde lichaams- 
deel. Voor de voet komt dit neer op $2 \mathrm{~cm}$ achter $\mathrm{Cz}$ (elektrodepositie $\mathrm{Cz}^{3}$ ). Ook voor de perins of clitoris is dit de beste plaats.

Het aspecifieke complex kan op alle elektrodeposities van het hoofd worden afgeleid.

Wat betreft de benoeming van de toppen wordt in het algemeen gekozen voor een letter waarmee de polariteit wordt aangegeven in combinatie met een getal dat de gemiddelde toplatentie in milliseconden aangeeft, bijv. N33 P40. Toppen worden echter ook wel aangegeven met een rangnummer al dan niet in combinatie met een letter voor de polariteit (NIP1).

De latentietijden zijn uiteraard afhankelijk van de plaats van stimulatie, de keuze van de zenuw en de instelling van de gebruikte apparatuur. Ook is er een geringe leeftijdsafhankelijkheid. Bij pasgeborenen zijn de latentietijden na vingerstimulatie ongeveer $8 \mathrm{~ms}$ langer doch na 2 maanden zijn ze reeds vergelijkbaar met die van volwassenen (Colon et al., 1983).

Over de specifieke vorm van de tibialis evoked potential valt nog het volgende te zeggen: Er bestaat in de literatuur verschil van mening over het wel of niet aanwezig zijn van de eerste negatieve top. Volgens Tsumoto et al. (1972) en Dorfman (1977) ontbreekt de N1 vaak of is nauwelijks aanwezig. Factoren hiervoor zijn het verschil in geleidingssnelheden van diverse afferente vezelgroepen, die tot een minder synchrone activering van de hersenschors zou leiden en een verschiliende ruimtelijke oriëntering van de corticalle generatoren (Dorfman, 1977). Jones en Small (1978), Ebensperger (1980), Eisen en Odusote ( $₫ 980)$ vonden echter dat de N1 meestal wel aanwezig is. Jones en Small (1978) vonden voorafgaande aan de P40, toppen die overeenkomen met de SSEP afgeleid van het rug* gemerg ter hoogte van de tweede cervicale wervel.

\section{Tabel 4.4}

De gemiddelde latentietijden in $\mathrm{ms} \pm S D$ van de eerste 3 negatieve en eerste 2 positieve toppen van de SSEP na stimulatie van de zenuwen van het been

\begin{tabular}{|c|c|c|c|c|c|c|}
\hline Auteurs & Stimulatie & $N 1(\mathbb{N} 33)$ & $\mathrm{P} 1(\mathrm{P} 40)$ & N2 (N5D) & $P 2(P 60)$ & $\mathbb{N} / 3(N 75)$ \\
\hline $\begin{array}{l}\text { Tsumoto et al. } \\
(1972)(n=41)\end{array}$ & $\begin{array}{l}\text { n. peroneus comm, } \\
\text { (fossa. poplitea) }\end{array}$ & - & $34,3 \pm 2,0$ & $44,8 \pm 3,3$ & $55,6 \pm 4,7$ & $74,2 \pm 5,6$ \\
\hline $\begin{array}{l}\text { Trojaborg en } \\
\text { Petersen }(1979) \\
(n=17)\end{array}$ & $\begin{array}{l}\text { n. peroneus comm. } \\
\text { (fossa poplitea) }\end{array}$ & - & $34 \pm 3,3$ & $44 \pm 3,9$ & $57 \pm 4,8$ & $72 \pm 7,3$ \\
\hline $\begin{array}{l}\text { Janes en Small } \\
(1978)(n=10)\end{array}$ & $\begin{array}{l}\text { n. tibialis } \\
\text { (mafleolus med.) }\end{array}$ & $33,9 \pm 1.7$ & $39,7 \pm 2,0$ & - & - & - \\
\hline $\begin{array}{l}\text { Eisen en Odiusate } \\
(1980)(n=25)\end{array}$ & $\begin{array}{l}\text { n. tibialis } \\
\text { (malleolus med.) }\end{array}$ & $31,9 \pm 1,7$ & $38,6 \pm 2,2$ & $49 \pm 1,8$ & $60 \pm 2,1$ & - \\
\hline $\begin{array}{l}\text { Eisen en Elleker } \\
(1980)(n=24)\end{array}$ & $\begin{array}{l}\mathrm{n} \text {. suralis } \\
\text { (malleolus lat.) }\end{array}$ & $35,1 \pm 1,9$ & $42,1 \pm 1,4$ & $53,1 \pm 2,3$ & $67,9 \pm 2,3$ & \\
\hline $\begin{array}{l}\text { Eisen en Elleker } \\
(1980)(n=25)\end{array}$ & $\begin{array}{l}\text { ni. siaphenus (voor } \\
\text { de malleolus med.) }\end{array}$ & $36,8 \pm 2,8$ & $43,4 \pm 2,2$ & $54 \pm 2,3$ & $66,7 \pm 3,3$ & \\
\hline $\begin{array}{l}\text { Eisen en Elleker } \\
(1960)(n=26)\end{array}$ & $\begin{array}{l}\text { n. peroneus sup. } \\
\text { (boven de malleolus } \\
\text { lat.) }\end{array}$ & $33,1 \pm 2,2$ & $39,9 \pm 1,8$ & $51 \pm 1,9$ & $65 \pm 3,3$ & \\
\hline
\end{tabular}


Gedurende de eerste $80 \mathrm{~ms}$ na stimulatie van de $\mathrm{n}$. tibialis wordt bij een positie van 2 $\mathrm{cm}$ achter $\mathrm{Cz}$ een $\mathrm{W}$-vormig complex geregistreerd dat bestaat uit twee of drie negatieve en twee positieve toppen. Het complex komt sterk overeen met het specifieke complex na stimulatie van de $n$. medianus. De latentietijden zijn ongeveer $15 \mathrm{~ms}$ langer.

De latentietijden zijn, zoais reeds eerder vermeld, afhankelijk van de plaats van stimulatie (knie of enkel), de keuze van de zenuw ( $n$. tibialis, $n$. peroneus communis, $n$. suralis of $\mathrm{n}$. pelvicus) en de instelling van de gebruikte apparatuur, vooral filterbandbreedte en analoge of digitale silgnaalverwerking. De latentietijden zijn bij mannen en vrouwen gemiddeld gelijk. De latentietijd is nauwelijks afhankelijk van de leeftijd (Ebensperger, 1980). Hij vond bij 38 normalen in de leeftijd van 18 tot 75 jaar een toename van de latentietijd van $0,04 \mathrm{~ms} / \mathrm{m}$ per levensjaar en dit is volgens hem terug te voeren op de geleidingsvertraging van de perifere zenuw bij het ouder worden. Ook is er een correlatie bij zowel vrouwen als mannen met de lengte, zowel wat betreft de been- als de lichaamslengte (Dorfman, 1977).

De door verschillende onderzoekers bepaalde gemididelde latentietijden van de eerste 3 negatieve en eerste 2 positieve toppen na stimulatie van de zenuwen van het been zijn samengevat in tabel 4.4. (zie blz,63)
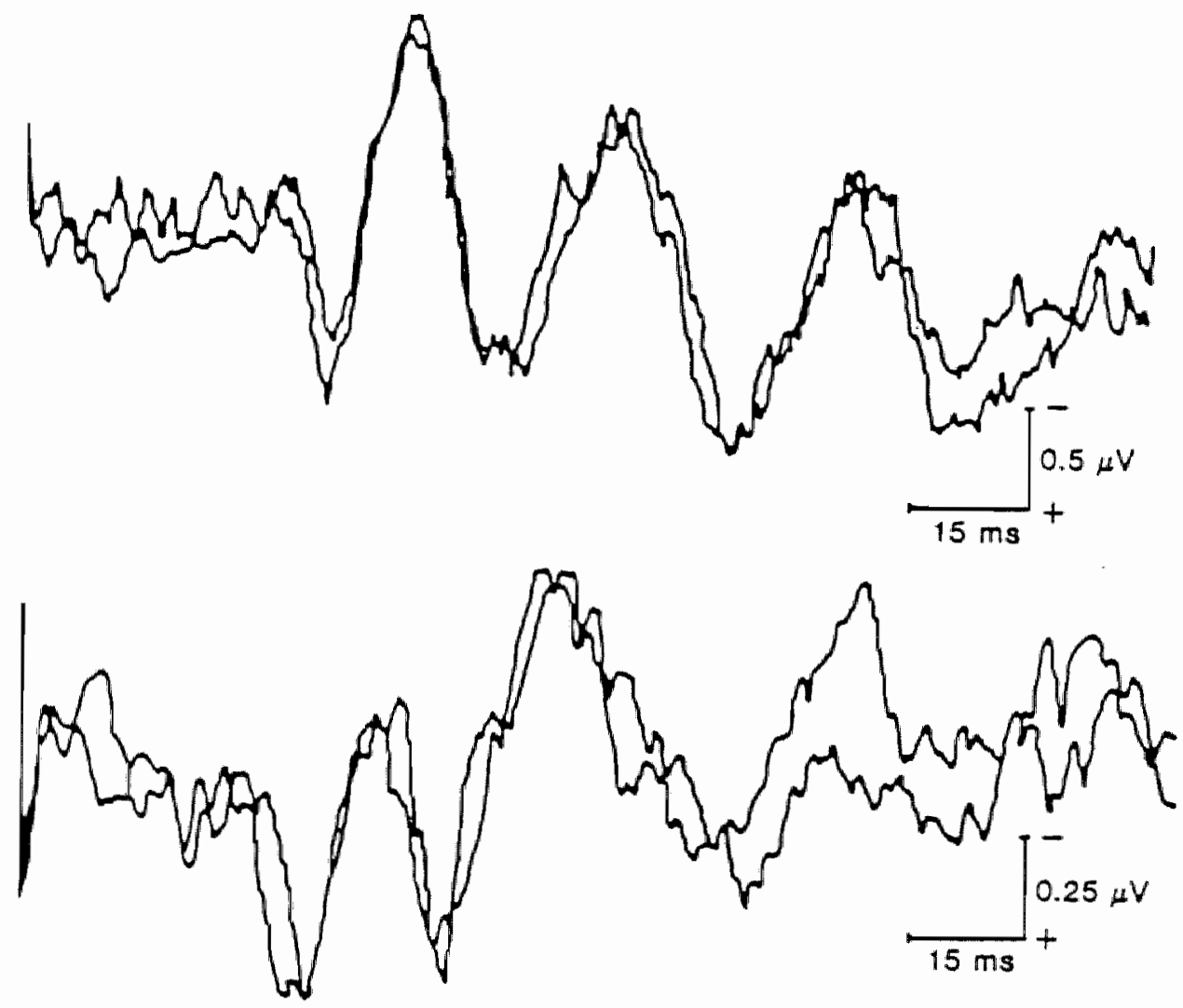

Pudendus Evoked Potential (Haldeman et al. 1982)

bij man (boven) en vrouw (onder)

Registratie $2 \mathrm{~cm}$ achter $\mathrm{Cz}-\mathrm{Fpz}$

1000 stimuli, frequentie $4,7 \mathrm{~Hz}$.

Frequentieband registratiesysterem LF: $3 \mathrm{~Hz} \quad \mathrm{HF}: 250 \mathrm{~Hz}$

Figurur 4.1 


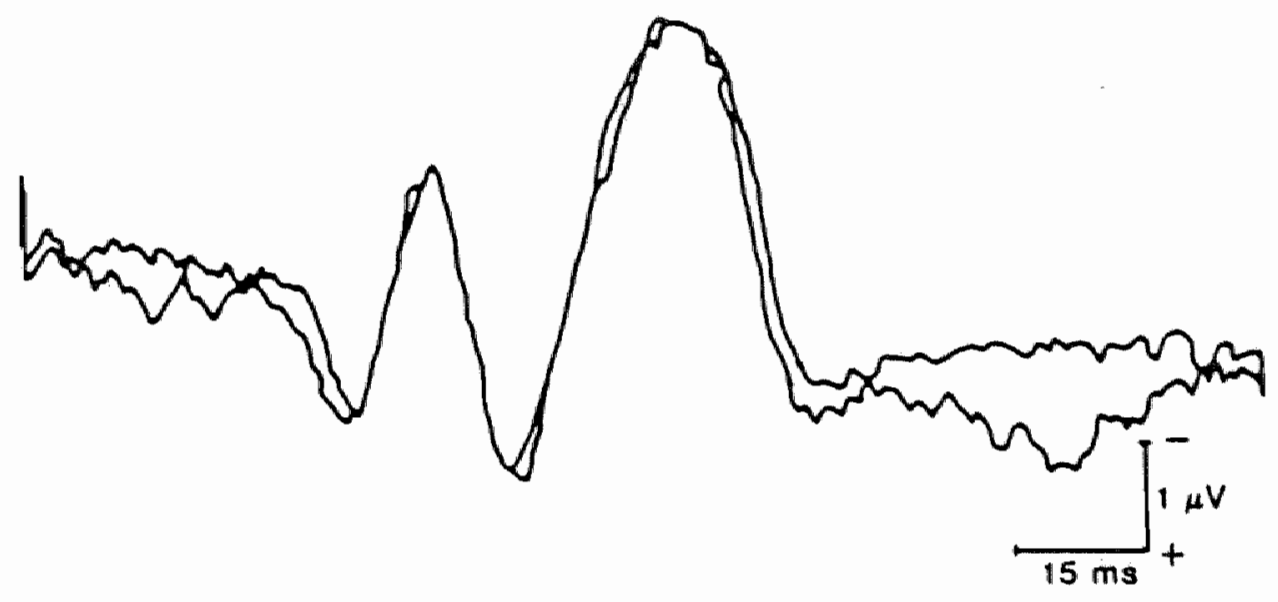

Tibialis Evoked Potential (Haldeman et al. 1982)

Registratie $2 \mathrm{~cm}$ achter $\mathrm{Cz}-\mathrm{Fpz}$

1000 stimuli, frequentie $4,7 \mathrm{~Hz}$

Frequentieband registratiesysteem LF: $3 \mathrm{~Hz} \quad \mathrm{HF}: 250 \mathrm{~Hz}$

Figuur 4.2

De vorm van de corticale PEP bij stimulatie van de $n$. dorsalis penis of $n$. clitoridis lijkt sterk op die van de TEP (zie figuren 4.1 op blz. 64 en 4.2). Men ziet bij de PEP meestal 3 of 4 negatieve en 3 of 4 positieve toppen maar soms meer. Het eerste deel van de PEP heeft vaak een $W$-vorm. De door de verschillende onderzoekers bepaalde corticale latentietijd van PEP tot de eerste positieve top bij proefpersonen, zijn samengevat in tabel 4.5.

Tabel 4.5

Literatuuroverzicht referentiewaarden latentietijden P $1(P 40)$ van de PEP

Haldeman et al. (1982)

Opsomer (1985)

Ertekin et al. (1985)
13 mannen

7 vrouwen

10 mannen

10 vrouwen

14 mannen
$42,3 \mathrm{~ms} \pm 1,9 \mathrm{~ms}$

$39,8 \mathrm{~ms} \pm 1,3 \mathrm{~ms}$

$43 \mathrm{~ms} \pm 3 \mathrm{~ms}$

$39,9 \mathrm{~ms} \pm 2$ ms

$43 \mathrm{~ms} \pm 3,6 \mathrm{~ms}$

Haldeman et al. (1982) vergeleken de latentietijden van de diverse componenten van de PEP en de TEP bij 13 gezonde mannen en 7 gezonde vrouwen (tabel 4.6). Haldeman et al. (1982) gebruikten een ander rangnummer voor de negatieve toppen dan in tabel 4.4 . $\mathrm{N} 0$ komt echter overeen met $\mathrm{N} 1$ en $\mathrm{N} 1$ met $\mathrm{N} 2$, enz. 
Vergelifking latentietijen van PEP en TEP bij 13 gezonde mannen en 7 gezonde vrouwen (Haldeman et al, 1982)

\begin{tabular}{llllllll}
\multicolumn{1}{c}{$N 0$} & $P 1$ & $N 1$ & $P 2$ & N 2 & $P 3$ & N 3 \\
Mannen (13) & & & & & & \\
TEP & $34,0 \pm 2,8$ & $41,2 \pm 2,9$ & $50,5 \pm 3,0$ & $62,7 \pm 3,3$ & $78,5 \pm 4,4$ & $99,5 \pm 6,0$ & $117,9 \pm 9,0$ \\
PEP & $35,2 \pm 3,0$ & $42,3 \pm 1,9$ & $52,6 \pm 2,6$ & $64,9 \pm 3,4$ & $79,3 \pm 4,0$ & $96,6 \pm 4,7$ & $116,0 \pm 7,2$ \\
Vrouwen (7) & & & & & & \\
TEP & $32,7 \pm 1,7$ & $39,3 \pm 1,4$ & $49,4 \pm 2,1$ & $60,0 \pm 2,0$ & $76,1 \pm 4,2$ & $96,1 \pm 5,8$ & $119,2 \pm 7,9$ \\
PEP & $32,9 \pm 2,9$ & $39,8 \pm 1,3$ & $49,1 \pm 2,3$ & $59,4 \pm 2,8$ & $73,4 \pm 4,6$ & $90,1 \pm 5,8$ & $110,0 \pm 10,2$
\end{tabular}

De variaties tussen beide SSEP's wat betreft de eerste negatieve en eerste positieve top zijn gering. Bij de latere toppen wordt de variatie groter. Er is ook weinig verschil wat betreft de toplatentietijden tussen mannen en vrouwen.

Haldeman et al. (1982) vonden dat de amplitudo van de PEP bij mannen gemiddeld twee maal zo groot was als bij vrouwen, respectievelijk 0,5 tot 2 uV en 0,2 tot $1 \mathrm{uV}$. Hij geeft als oorzaak hiervan aan dat de penis duidelijker in de cortex gerepresenteerd is dan de clitoris. Een andere oorzaak kan zijn een kleiner aantal zenuwvezels in de clitoris. Doch de meest waarschijnlijke oorzaak is dat de $n$. dorsalis penis gemakkelijker gestimuleerd kan worden dan de $n$. clitoridis (Haldeman et al., 1982).

De amplitudo van de corticiale TEP is bij het onderzoek van Haldeman tweemaal zo groot als die van de PEP. Een mogelijke oorzaak hiervan kon volgens hem zijn dat de penis en clitoris dieper in de fissura interhemisferica zijn gerepresenteerd dan de voet. De afstand tot de afleidelektrode is groter. Als tweede mogelijke oorzaak gaf hij aan, dat een kleiner aantall axonen in de $\mathrm{n}$. pudendus gestimuleerd worden dan bij de $\mathrm{n}$. tibialis. Hoe meer de respons vertraagd is, des te lager is de amplitudo door het verschil in geleidingssnelheid. De amplitudo is ook afhankelijk van de intensiteit van de stimulus (Haldeman et al., 1982). Dit hangt samen met het aantal vezels dat geprikkeld wordt. Bij lage intensiteit vindt men een lagere amplitudlo. Ook Uttal en Cook (1964) vonden dat de latentietijden en de amplitudo varieerden met de stimulusintensiteit. Bij een vertraagde respons vonden Haldeman et al. (1982) bovendien dat de duur van het golfcomplex korter werd.

Haldeman et al. (1982) registreerden na stimulatie van de $n$. pudendus ook een spinale PEP over de eerste lumbale wervel. De vorm was monofasisch of trifasisch met een relatief hoge negatieve top. De latentietijd van de grote negatieve top na stimulatie van de n. pudendus bij gezonde mannen was $12,9 \pm 0,8$ ms en de latentietijd van de eerste negatieve top van de spinale TEP was $24,6 \pm 2,3$ ms. Het verschil in latentietijden kan berusten op een geringere lengte van de $n$. pudendus of een tragere geleiding. De amplitudo van de spinale TEP na stimulatie van de $n$. tibialis was zoals eerder gezien bij de corticale TEP ongeveer tweemaal zo groot als na stimulatie van de $n$. pudendus. Bij dikke mannen en vrouwen lukte het niet om een respons te registreren. De oorzaak hiervan is een te grote afstand tussen generator en afleidelektrode.

De voornaamste negatieve top van de spinale PEP wordt waarschijnlijk gegenereerd in het caudalle deel van het ruggemerg (Cusick et al., 1979). De latentietijd tot de negatieve top kan worden geinterpreteerd als de perifere geleidingstijd.

Haldeman et al. (1982) bepaalden ook de centrale geleidingstijd (dit is de geleiding door het ruggemerg en de hersenstam) bij 13 gezonde mannen voor de TEP en de PEP. Zij namen hiervoor het verschil in latentietijd tussen de eerste positieve top op de schedel en de eerste negatieve top ter plaatse van de eerste lumbale wervel. De gemiddelde centrale geleidingstijd voor de TEP was $16,5 \pm 1,6 \mathrm{~ms}$ en voor de PEP $30,0 \pm 3,2 \mathrm{~ms}$. De centrale geleidingstijd voor de $\mathrm{n}$. pudendus is dus ongeveer $13 \mathrm{~ms}$ langer. Dit kan veroor- 

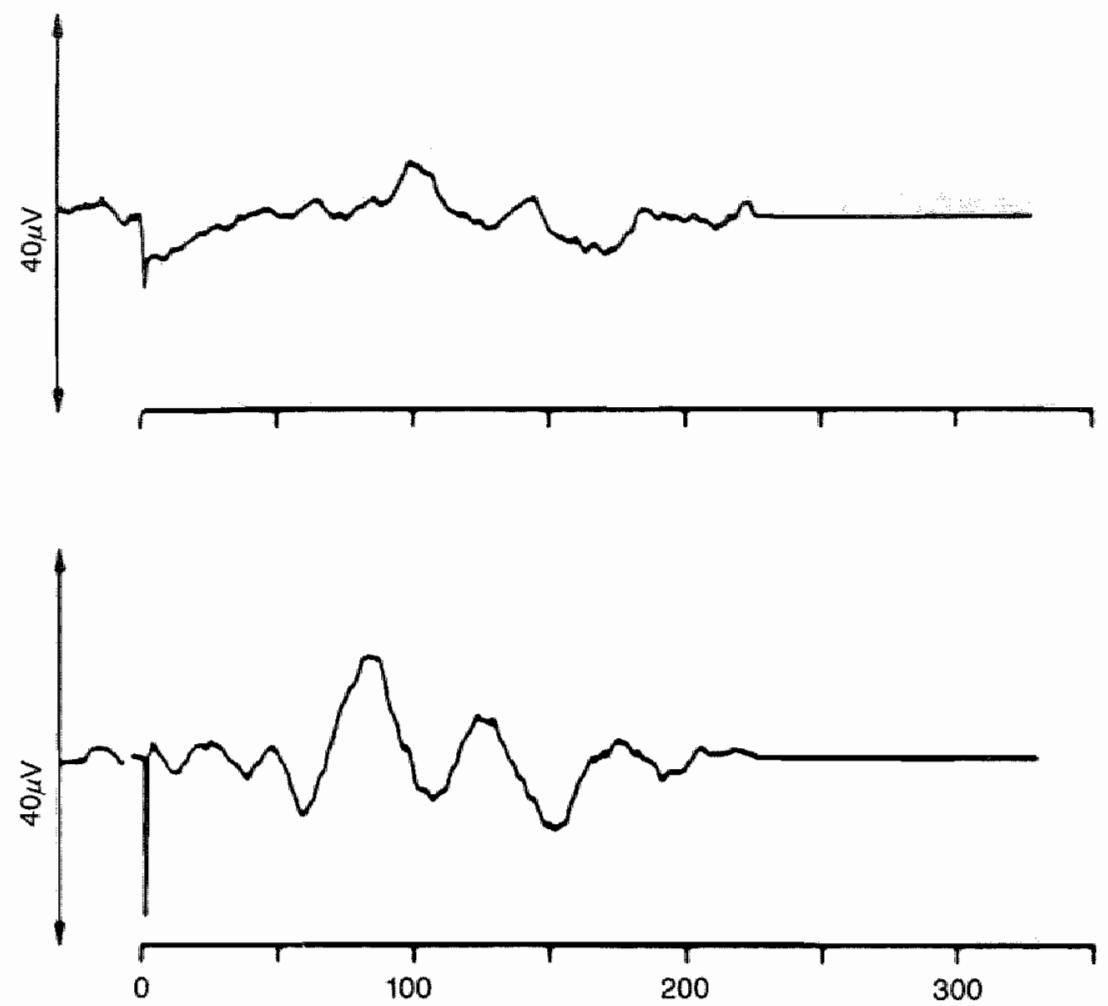

Pelvicus Evoked Potential (Badr et al. 1982)

na bipolaire stimulatie (boven)

en monopolaire stimulatie (onder)

Registratie $1,5 \mathrm{~cm}$ achter $\mathrm{Cz}-\mathrm{Fpz}$

1000 stimuli, frequentie $1,8 \mathrm{~Hz}$

Frequentieband registratiesysteem LF: $16 \mathrm{~Hz} \quad \mathrm{HF}: 800 \mathrm{~Hz}$

Figuur 4.3

zaakt worden door een verschil in route van de afferente prikkels van de $n$. pudendus door het ruggemerg en de hersenstam. Een andere mogelijkheid is, dat dit veroorzaakt wordt door een verschil in vezeldiameter.

Er zijn tot nu toe weinig meldingen over meting van de SSEP van de $n$. pelvicus (hypogastricus) (PHEP) bij stimulatie van de blaas. Dit komt waarschijnlijk door de ongewone stimulatieprocedure.

Badr et al. (1982) beschreven een polyfasische corticale SSEP na monopolaire en bipolaire stimulatie van de blaaswand (figuur 4.3). Bij monopolaire stimulatie werd een indifferente elektrode op de dij geplaatst. De meest duidelijke toppen die zij vonden waren: $N 45(S D=4), P 65(S D=4), N 82(S D=6)$ en $P 102(S D=7)$. Zowel vroegere als latere positieve en negatieve toppen werden gevonden.

Bij monopolaire stimulatie moet men zich afvragen of de SSEP door stimulatie van uitsluitend de blaaswand wordt opgewekt. Het is ook mogelijk dat de SSEP geproduceerd of wezenlijk veranderd wordt door directe activiteit of reflexactiviteit uit de hamstrings. Hiervoor pleit dat de maximale amplitudo van de blaas-SSEP wordt verkregen over het beengebied van de gyrus postcentralis. Hiertegen pleit echter dat de SSEP niet wordt gezien wanneer opzettelijk een spiercontractie opgewekt wordt door directe stimulatie van de dij. De PHEP heeft nagenoeg dezelfde vorm als de TEP doch met een andere latentietijd. 
Bij bipolaire stimulatie van de $n$. pelvicus wordt er ook een polyfasische SSEP geregistreerd, doch met een kleinere amplitudo en licht afwijkende latentietijden in vergelijking met de monopolaire stimulatie. Deze respons is voigens Badr et al. (1982) zeker afkomstig wan blaasafferenten an wordt opgewekt door impulsen die verlopen via de afferenten van de $\mathrm{n}$. pelvicus en de $\mathrm{n}$. hypogastricus.

Bi] monopolaire stimulatie wordt volgens Badr et al. (1982) waarschijnlijk een samengestelde respons geregistreerd, afkomstig van de afferenten van de n. pelvicus, n. hypogastricus en $n$. pudendus. Bovendien is er een bijdrage van zenuwen in de omgeving zoals de $n$. obturatorius.

\subsubsection{BEVINDINGEN BIJ DIABETICI}

Verschillende auteurs registreerden de TEP bij patienten mell diabetes mellitus. Dit waren vaak kleine groepen patienten.

Gupta en Dorfman (1981) registreerden de TEP echter bij 65 diabetici met een gemiddelde leeftijd van 34,3 jaar (SD 12,4). De duur van de ziekte varieerde van 3 tot 27 jaar. De onderzochte diabetici hadden geen tekenen van een polyneuropathie. Zij vonden een gemiddelde latentietijd tot de eerste negatieve top van $41,3 \mathrm{~ms}$ (SD 6,2).

Literatuurgegevens betreffende de PEP bij diabetici zijn schaars. Ertekin et al. (1985) vonden bij $2(10 \%)$ van de 20 patienten met diabetes mellitus en een erectiestoornis een vertraagde PEP (gemiddeld 47,2 ms (SD 6,2)).

Geen meldingen werden gevonden over de latentietijd van de PHEP bij diabetes mellitus.

\subsubsection{H-REFLEX}

\subsubsection{INLEIDING}

De H-reflex werd het eerst door Hoffmann in 1920 beschreven. Angel en Hoffmann (1963) en Mayer en Mawdsley (1965) introduceerden de H-reflex in het kilinisch-elektromyografisch onderzoek.

De H-reflex is een reflex-respons welke kan worden opgewekt bij stimulatie van sommige gemengde perifere zenuwen. De H-reflex is gemakkelijk opwekbaar in de $\mathrm{m}$. soleus na stimulatie van de $n$. tibialis in de knieholte. De H-reflex is echter ook opwekbaar na stimulatie van de $n$. peroneus in de $m$. extensor digitorum brevis, de $n$. femoralis in de $m$. quadriceps femoris en in de $\mathrm{m}$. flexor carpi radialis na stimulatie van de $n$. medianus. Bij pasgeborenen is deze reflex ook goed opwekbaar in de kleine hand- en voetspieren. Bif volwassenen is uit de ontspannen kleine hand-en voetspieren normaliter geen H-reflex to verkrijgen.

\subsubsection{REFLEXBOOG}

Wanneer men de $\mathrm{n}$. tibialis in de fossa poplitea stimuleert ontstaan in de $\mathrm{m}$. soleus twee responsen:

1. prikkeling van de motore efferente vezels geeft een direct spierantwoord (M-respons) met een latentietijd van 3 - $5 \mathrm{~ms}$

2. prikkeling van de proprioceptieve vezels geeft een indirect spierantwoord. Dit is de $\mathrm{H}$ reflex welke bij volwassenen een latentietijd heeft van 26 tot $34 \mathrm{~ms}$. Het eerste deel van de reflexboog wordt gevormd door \& A afferenten die afkomstig zijn uit de spierspoelen. Deze vezels synapteren de motorische voorhoorncellen en de opgewekte impulsen lopen via motorische vezels naar de $\mathrm{m}$. soleus 


\subsubsection{WIJZE VAN UITVOERING}

De methodiek van het onderzoek werd in 1974 door Notermans en Vingerhoets als volgt beschreven. De stimulatie-elektroden met de kathode ongeveer $2 \mathrm{~cm}$ voor de anode, wor* den over de $\mathrm{n}$. tibialis in de knieholte van de patient geplaatst. Deze ligt in buikligging met de knie in lichte flexie. Het onderzoek vindt plaats bij een huidtemperatuur van $32^{\circ} \mathrm{C}$. Gestimuleerd word" met elektrische rechthoekprikkels met een duur van 0,2 tot $1 \mathrm{~ms}$. De registratie vindt in het algemeen plaats door middel van oppervlakte-elektroden. Voor de $\mathrm{m}$. soleus worden zij in de mediaanlijn op $5 \mathrm{~cm}$ van elkaar boven deze spier geplaatst en bevestigd. De proximale elektrode moet $2 \mathrm{~cm}$ distaal van de onderrand van de spierbuik van de $\mathrm{m}$. gastrocnemius liggen.

Wanneer de prikkelsterkte van subliminaal geleidelijk wordt opgevoerd verschijnt normaliter eerst de $\mathrm{H}$-reflex. Bij toenemende prikkelsterkte ontstaat er ook een directe motorische respons voor de H-reflex. Bij supramaximale prikkelsterkte stijgt de $\mathrm{M}$-respons tot maximale grootte en verdwijnt de $\mathrm{H}$-reflex ten gevolge van antidrome motorische gelelding, gevolgd door een refractaire periode.

De latentietijd van de H-reflex is belangrijk om een indruk te krijgen over het geleidingssysteem van de totale afferente baan, de synaps en de efferente baan. Wanneer de geleidingssnelheid van de efferente baan bekend is kan uit de reflextijd indirect een indruk verkregen worden over de geleiding van de afferente zenuw.

\subsubsection{H-REFLEX PARAMETERS}

De latentietijd van de $\mathrm{H}$-reflex verminderd met de latentietijd van de $\mathrm{M}$-respons wordt het H-M interval genoemd. Het zenuwtraject distaal van de stimulatie-elektrode wordt dan buiten beschouwing gelaten, zodat het niet gelijk plaatsen van de elektrode op de $\mathrm{m}$. solleus geen invloed heeft op de latentietijd van de $H$-reflex. De duur van het $H-M$ interval is afhankelijk van het zenuwtraject van knieholte tot ruggemerg. Bij gezande proefpersonen bedraagt het verschil in het $\mathrm{H}-\mathrm{M}$ interval tussen de registratie van de $\mathrm{m}$. gastrocnemius links en rechts en $\mathrm{m}$. soleus links en rechts niet meer dan $3 \mathrm{~ms}$ (Visser et al., 1983). Bij polyneuropathile en radiculaire aandoeningen kan het $H-M$ interval verlengd zijn. Wat betreft de amplitudo van de $\mathrm{H}$-reflex zijn er individuele verschillen van 2 - $10 \mathrm{mV}$ (Visser, 1981). De meest stabiele parameter is het quotiënt van de maximale amplitudo van de M-respons, de H/M ratio. Het geeft een indruk van de verhouding van het maximale aantal reflectoir te activeren motorunits in vergelijking met het totale aantal motorunits. Het verschil tussen de $\mathbb{H} / \mathrm{M}$ ratio links en rechts bedraagt voor overeenkomstige spieren niet meer dan 50\% (Notermans en Vingerhoets, 1974).

Visser et al. (1983) onderzochten het effect van de leeftijd en de lichaamslengte op de latentietijd van de $\mathrm{H}$-reflex ( $\mathrm{H}-\mathrm{M}$ interval). Zij kwamen tot de volgende formule: $\mathrm{H}-\mathrm{M}$ interval (in ms) $=0,058 \times$ leeftijd (jaren) $+0,120 \times$ lichaamslengte $(\mathrm{cm})+2,70 \pm 1,37$.

$\mathrm{De}$ normale bovenste limiet $(\mathrm{M}+2 \mathrm{SD})$ van het $\mathrm{H}-\mathrm{M}$ interval varieert volgens hen van 22 ims (man $155 \mathrm{~cm}, 20$ jaar) tot $34,3 \mathrm{~ms}$ (vrouw $195 \mathrm{~cm}, 70$ jaar).

\subsubsection{BEVINDINGEN B\|J DIABETICI}

Wager en Buerger (1974) berekenden bij diabetici de sensibele geleidingssnelheid via het verschil in de latentietijd van de H-reflex. Zij vonden dat de geleidingssnelheid bij diabetici trager was in vergelijking met de normale populatie.

Notermans et al. (1977) wonden bij $77 \%$ van de 40 onderzochte diabetici een verlengd $\mathrm{H}$ $M$ interval na stimullatie van de $n$. tibialis en bij registratie uit de $\mathrm{m}$. soleus. Zij vonden dat het $\mathrm{H}-\mathrm{M}$ interval het meest gevoelige elektromyografische teken was bij diabetici om een polyneuropathie aan te tonen in vergelijking met overige elektromyografische afwijkingen. 
Bertelsmann et al (1986) onderzochten het H-M interval bil 50 insuline afhankelike diabelici na stimulatie van de $n$. tibialis en bij registratie uit de $\mathrm{m}$. soleus. 34 Patienten hadden wel en 16 geen symptomen van een neuropathie. Het $H-M$ interval werd geëvalueerd in relatie tot de normale bovenste limiet $(M+2 S D)$ waarbij rekening werd gehouden met de leeftijd en lichaamslengte. Zij wonden bij $91,2 \%$ van de patienten met symptomen van een neuropathie en bij $62,5 \%$ van de patienten zonder tekenen van een neuropathie een verlengde $\mathrm{H} \cdot \mathrm{M}$ interval.

\subsubsection{TE VERWACHTEN STOORNISSEN VAN DE NEUROFYSIOLOGISCHE TESTS BIJ LETSELS OP VERSCHILLENDE NIVEAUS VAN DE UROGENITALE INNERVATIE}

Het onderzoek van de latentietijd van de VAR en de BCR I spoort geleidingsstoornissen op in de $n$. pelvicus, $n$. hypogastricus en $n$. pudendus zowell motorisch als sensibel. $D e$ PEP en PHEP geven inlichtingen omtrent de integriteit van de ascenderende baansystemen in het ruggemerg (achterstreng/lemniscussysteem).

Door de resultaten van het onderzoek van deze reflexen, evoked-potentials en hel elektromyografisch anderzoek van de $\mathrm{m}$. sphincter ani externus te combineren, kan men onderscheid maken tussen een autonoom (n. pelvicus, $n$. hypogastricus), somatisch afferent (sensibele pudendus), somatisch efferent (motorische pudendus) en suprasegmentaal letsel (achterstreng/lemniscussysteem).

Daarnaast kan men een indruk krijgen over het functioneren van de pyramidebaan via het al of niet kunnen aanspannen van de $\mathrm{m}$. sphincter ani externus bii een intact somatisch efferent deel van de $n$. pudendus (tabel 4.7). 
Te verwachten neurofysiologische stoornissen bij letsels op verschillendi niveaus van de urogenitale innervatie

letsel

VAR BCR ॥ PEP PHEP

spontane
spiervezel-
potentialen
m. sph. ani
externus

maximaal

aanspannings-

patroon

m. sph. and

externus

n. pelvicus

(perifeer sensibel)

n. pudendus

(perifeer sensibel)

n. pudendus

(perifeer motorisch)

n. pudendus

(perifeer motorisch

axonaal)

pyramidebaan laesie

pudendus vezels

in ruggemerg

n. hypogastricus

(perifeer sensibel)

of hypogastricus

vezels in ruggemerg

pelvicus vezels

in ruggemerg, hypo-

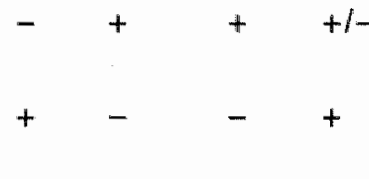

$+$

$+$

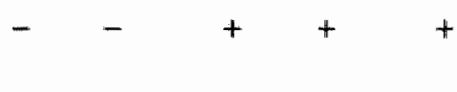

$+$

$+$

$+$

$+\quad+$

gastricus vezels

in ruggemerg of

$\mathrm{n}$. hypogastricus

(perifeer sensibel)

$+=$ normaal

- = afwijkend

\subsection{BESCHRIJVING UROLOGISCHE METHODEN}

\subsubsection{INLEIDING}

In dit hoofdstuk wordt een korte beschrijving gegeven van de urologische onderzoekmethoden, voor zover relevant voor dit onderzoek. Tijdens het cystoscopisch onderzoek wordt gelet op morfologische afwiljkingen. Het urodynamisch onderzoek bestaat uit het meten van de drukverhoudingen in de blaas en in de urethra. Hierdoor is het mogelijk eventuele dysfuncties van de lagere urinewegen te abjectiveren. Het meten en vastleggen van de afwijkingen vindt plaats tijdens blaasvulling en mictie.

De bevindingen bij urodynamisch onderzoek tijdens de mictie berusten op een samenspel van verschillende fysiologische mechanismen. Zil verschillen sterk bij verschillende individuen en onder verschillende omstandigheden.

Het is daardoor niet mogelijk een diagnose te stellen op uitsluitend urodynamische bevin. dingen. 
Naast deze urodynamische onderzoektechnieken wordt veelal ook het elektromyogram van de $\mathrm{m}$. sphincter ani externus en de $\mathrm{m}$. sphincter urethrae externus tijdens de mictie geregistreerd.

\subsubsection{CYSTOSCOPIE}

De cystoscopie is een endoscopisch onderzoek van de blaas en urethra. Door middel van cystoscopisch onderzoek kunnen slechts morfologische veranderingen, worden vastgesteld, zoals anatomische infravesicale obstructie, trabekellblaas, cystocele, de grootte van de blaas, de ureter-ostia en afwijkingen van het blaasslijmwlies. Trabekulatie wijst op een sterke detrusoractiviteit. Dit kan het gevolg zijn van een neurogeen blaaslijden of van een infravesicale obstructie.

\section{Bevindingen bil diabetici}

Ellenberg (1966) vond bij cystoscopie bij diabetici zonder infravesicale obstructie een toename van de blaascapaciteit, een verminderde sensibiliteit en enige trabekulatie. Fagerberg et al. (1969) vonden bij 15 van de 29 onderzochte diabetici een inadequate $\mathrm{m}$. sphincter urethrae internus en externus. Lich en Grant (1948), Kahan et al. (1970), loanid et al. (1981) en Manning en Ireland (1982) vonden bij cystoscopie een klein en onregelmatig trigonum, een prominerend ligamentum interuretericum, een korte lengte van de urethra prostatica, een hypertrofie van de blaashals en een geringe trabekulatie zonder infravesicale obstructie. Lich en Grant (1948) wonden dit bij $43 \%$ van de diabetici en loanid et al. (1981) vonden dit zelfs bij alle door hen onderzochte diabetici met klinische problematiek. Kahan et al. (1970) schreven de hypertrofie van de blaashals toe aan een chronisch blaasinfect.

\subsubsection{CYSTOMETRIE}

De cystometrie is een functioneel onderzoek waarbij de druk wordt gemeten in de blaas tijdens de vulling en de mictie.

Cystometrie is een op zichzelf staande test van de detrusorfunctie. Deze onderzoekmethode geeft slechts zeer beperkte informatie over de innervatie van het urogenitale systeem (Bradley et al., 1976; Howard, 1982).

Tijdens de vullingsfase van de blaas geeft het cystometrogram uitsluitend elastische karakteristieken van de blaaswand weer. Deze zijn niet neurogeen beïnvloedbaar (Bradley et al., 1976).

De cystometrie verloopt als volgt: 2 dunne katheters worden via de urethra in de blaas gebracht. Eén van deze katheters dient om de blaas geleidelijk te vullen met gas, water of contrastvloeistof. De andere katheter dient om de intravesicale druk te meten. Een derde katheter meet de druk in het rectum. Men gaat er van uit dat de intrarectale druk overeenkomt met de intra-abdominale extravesicale druk. Men berekent de detrusordruk of intrinsieke blaasdruk door de intrarectale druk wan de intravesicale druk af te trekken (Blaivas, 1979).

Bij een cystometrogram (fig. 4.4) onderscheidt men vier segmenten, waarvan de eerste 3 bij de vullingsfase horen en waarbij het vierde segment de mictiefase (detrusorcontractie) weergeeft (Blaivas, 1979). Tijdens het begin van de vulling in een lege blaas is er een geringe drukverhoging (segment 1), die gelijk is aan de detrusordruk in rust. Bij toenemend volume zal de blaaswand zich aanpassen en gerekt worden zonder tot een 
noemenswaardige intrawesicale drukverhoging aanleiding te geven (segment 2). Wanneer de detrusonwand maximaal gerekt is - en dit zonder detrusorcontractie - kan er een verdere, lichte drukstijging optreden (segment 3). Dit verschijnsell wordt door Swaiman en Bradley (1967) toegeschreven aan de extreme rekking van de collagene elementen. Het einde van segment 3 betekent het bereiken van de blaascapaciteit. Het vierde segment is de mictiefase, waarbij de sphincters zich ontspannen en waarbij detrusorcontracties optreden om de blaas te ledigen.

De detrusordruk in rust (segment 2) bedraagt normaal $15-20 \mathrm{~cm}$ water, de blaascapaciteit $400-600 \mathrm{ml}$. De gemiddelde waarde van de normale druk tijdens de mictie bedraagt bil de vrouw $30 \mathrm{~cm}$ water en bij de man $40.50 \mathrm{~cm}$ water.

De onderzochte moet aangeven wanneer hij de mictiedrang voelt opkomen, wanneer hij pijn voelt en wanneer hij de mictie niet meer kan ophouden. De onderzoeker zal de patient moeten voorlichten en instrueren over het onderzoek, hem moeten aansporen de mictie op te houden gedurende de te verwachten duur van de vullingsfase en tot mictie over te gaan bij het bereiken van de te verwachten blaascapaciteit.

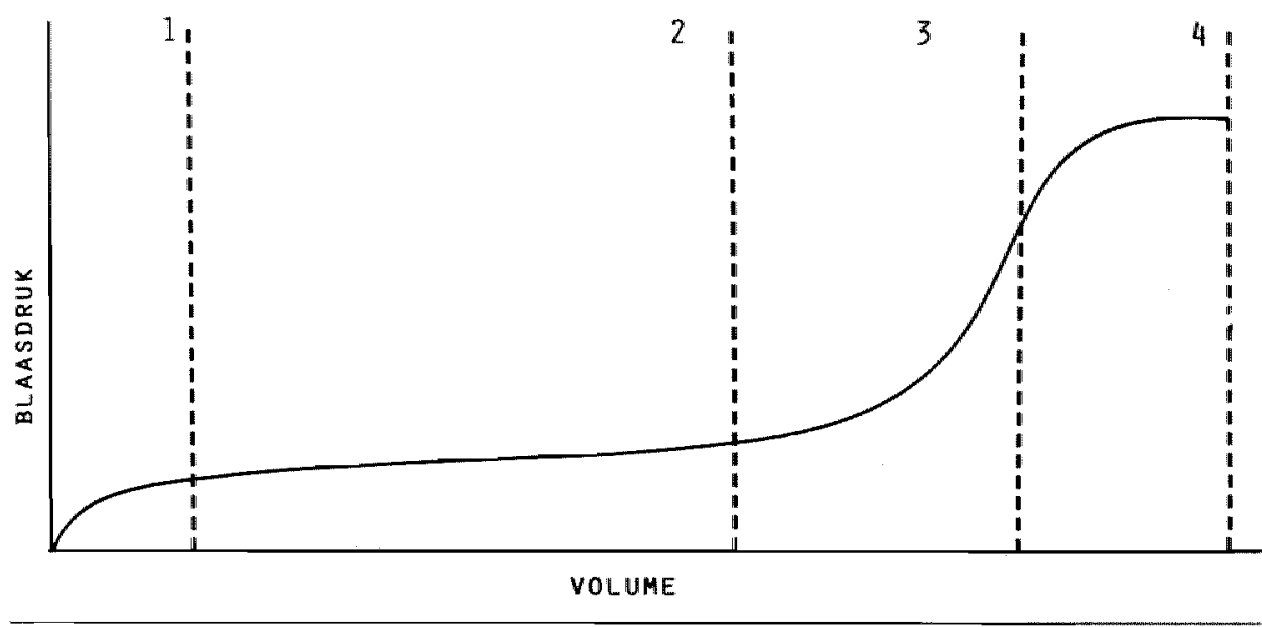

Figuur 4.4.

Schematische weergave van een normale cystometrie (voor toelichting zie tekst)

Men zal er rekening mee moeten houden, dat bij de cystometrie de metingen beïnvloed zullen worden door de onfysiologische en weinig comfortabele omstandigheden waarin de patient zich bevindt, wanneer hij het tijdstip van de mictiedrang of pijn zal moeten aangeven c.q. wanneer hij de mictie moet ophouden.

De metingen zullen ook beïnvloed worden door de houding van de patient en door de snelheid waarmee de blaas gevuld wordt. Om aan al deze bezwaren tegemoet te komen heeft men een methode ontwikkeld waarbij met behulp van een cassette-recorder gedurende de activiteiten van het dagelijks leven door 2 katheters het cystometrogram kan worden geregistreerd. De vulling van de blaas wordt bereikt door de natuurlijke excretie van de nieren (Bhatia en Bradley, 1982).

Gedurende het cystometrisch onderzoek zall vooral gellet moeten worden op urineretentie, blaascapaciteit, contractiliteit en sensibiliteit van de blaaswand.

\subsubsection{URINERETENTIE}

Bors (1957) stelde dat een blaasresidu pathologisch verhoogd is wanneer dit groter is dan $10 \%$ van de blaascapaciteit. 
Frimodt-Mollier (1976a) vond dit bij bijna de helft van de door hem onderzochte diabetici met een cystoneuropathie. De gevonden waarden van het residu bij diabetici variëren in de literatuur aanzienlijk, van $0 \mathrm{ml}$ (Faerman, 1971; Frimodt-Møller, 1976a) tot $3500 \mathrm{ml}$ (EIlenberg, 1966).

\subsubsection{BLAASCAPACITEIT}

Er is verschil van mening over de grens tussen een normale en een pathologisch verhoogde blaascapaciteit. Dit varieerde bij de verschillende auteurs van $400 \mathrm{mll}$ (Kahan et al. ,1970) tot $700 \mathrm{ml}$ (Hopkins en Pierce, 1967).

\section{Bevindingen bij diabetici}

Rundles (1945), Ellenberg (1966 en 1971), Hopkins en Pierce (1967), Kahan et al. (1970), Faerman et al. (1971), Buck et al. (1976) en Frimodi-Møller (1976a) vonden door middel van cystometrisch onderzoek bij diabetische cystoneuropathie een toegenomen blaascapaciteit.

\subsubsection{CONTRACTILITEIT}

Bij een normale contractiliteit zal pas een uitgesproken detrusorcontractie optreden wanneer, bij het bereiken van de blaascapaciteit, de patient het verzoek krijgt te urineren. Geringe contracties kunnen plaatsvinden gedurende de vullingsfase (figuur 4.5).

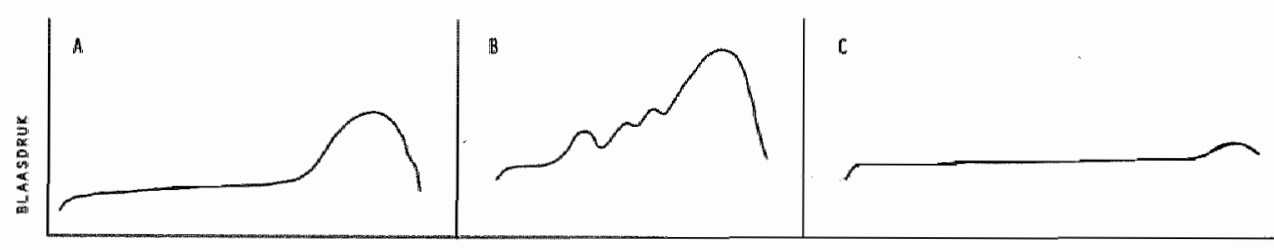

WOL UWE

\section{Figuur 4.5}

Schematische voorstelling van een normale (A), van een hypertone (B) en van een hypotone (C) cystometrische curve.

Een hyperreflexie of hypertonie zal bij het cystometrisch onderzoek (figuur 4.5) op verschillende wijzen tot uiting kunnen komen:

- in de vullingsfase detrusorcontracties met drukverhogingen boven $15 \mathrm{~cm}$ water

- in de vullingsfase detrusorcontracties die door de patient niet onderdrukt kunnen worden

- vroegtijdige detrusorcontracties die leiden tot een onvrijwillige mictie

- een geringe blaascapaciteit

- een vroegtijdig aandranggevoel

- een hoge intravesicale druk bij de mictie. 
Soms zal een hypertonie pas op de curve tot uiting komen bi] het provoceren wan detrusorcontracties door suprapubische blaasstimulatie (buikkloppen) of door het opwekken van een hoge intra-abdominale druk (hoesten, verandering van houding).

Een le grote detrusoractiviteit (hyperreflexie of hypertonie) kan weroorzaakt worden door een locale irritatie (ontsteking, tumor, steen, prostaathypertrofie) of door een neurologisch lijden, dat gepaard gaat met een onderbreking van loop Bradley (zie blz. 30). Wanneer geen oorzaak voor de hyperactiviteit van de detrusor vastgesteld kan worden, spreekt men van een "unstable bladder".

Klinisch zal een hypertonie zich kunnen uiten door pollakisurie, onderbuikspijn en incontinentie.

Een verminderde detrusoractiviteit (hyporeflexie of hypotonie, areflexie of atonie) zal bi) het cystometrisch onderzoek (figuur 4.5) op verschillende wijzen tot uiting kunnen komen:

- een urineretentie

- een grote blaascapaciteit

- een geringe druk in de blaas in rust (segment 2 , fig. 4.4)

- de onmogelijkheid orm op het einde van het onderzoek tot een mictie te komen. Soms echter zullen gezonde patienten op commando niet kunnen urineren in deze oncomfortabele omstandigheden

- een lage intravesicale druk bij de mictie

- een aandranggevoel dat slechts later dan normaal optreedt. Dit kan echter ook het ge. volg zijn van een hypo-aesthesie van de blaaswand.

De verminderde detrusoractiviteit kan ook veroorzaakt worden door een decompensatie van de detrusor na een langdurig bestaande infravesicale obstructie, door farmaca en door een neurogeen lijden, met name door een laesie van loop II of III (Bradley, 1978) (zie blz. 30). Hypo- of areflexie zullen klinisch tot uiting komen door een moeilijke, langdurige mictie met een slappe straal, door een frequente mictie met kleine porties, door een overflow-incontinentie of door een complete urineretentie.

\section{Bevindingen bij diabetici}

Bij cystometrisch onderzoek vonden Bradley (1980), loanid et al. (1981) en Howard (1982) bij patienten met diabetes mellitus twee soorten afwijkingen, die ook thans nog aanvaard worden.

1. Detrusorareflexie en verminderde sensatie bij blaasvulling. Dit vindt men bij langdurig insuline afhankelijke diabetici, die primair een laesie hebben van de n. pelvicus. Op deze wijze kan een atone blaas ontstaan zonder een infravesicale obstructie.

De blaaswand toont hierbij nauwelijks of geen trabekulatie. In het beginstadium veroorzaken deze afwijkingen geen symptomen.

2. Detrusorhyperreflexie.

Hierbij kan de patient de detrusorreflex niet op commando onderdrukken. Dit impliceert dat corticale of spinale regulerende verbindingen, die de detrusorspier innerveren zijn onderbroken. Een vascularisatiestoornis is waarschijnlijk de oorzaak.

Fagerberg (1967) en Andersen en Bradley (1980) vonden door middel van cystometrisch onderzoek resp. bij $43 \%$ en $50 \%$ een detrusorareflexie bij diabetici. Andersen en Bradley (1980) vonden bij 7 patienten (23\%) van de 30 onderzochte diabetici een detrusorhyperreflexie.

\subsubsection{SENSIBILITEIT VAN DE BLAASWAND}

De normale proprioceptieve sensibiliteit tijdens cystometrie wordt gekenmerkt door een eerste aandrang bij een vulling met 150 tot $250 \mathrm{ml}$ en vervolgens door een maximale aandrang bij een vulling van 400 tot $600 \mathrm{ml}$ (functionele blaascapaciteit). De blaasvulling 
waarbil het aandranggevoel zou moeten optreden verschilt volgens verschillendle auteurs en varieert van $200 \mathrm{ml}$ (Motzkin, 1968) tot $600 \mathrm{ml}$ (Fagerberg et al., 1967). Afwijkingen in de sensibiliteit zijn een verminderde of ontbrekende aandrang bij vulling enerzijds en hyperaesthesie bil geringe wulling anderzijds.

De exteroceptieve sensibiliteit wordt getest door wulling van de blaas met successieveliik koud en heet water waarbij de patient het verschil aangeeft.

\section{Bewindingen bij diabetici}

Frimodt-Møller (1976a) vond bij patienten met een diabetische cystoneuropathie een eerste aandrangsensatie bij 400 tot $700 \mathrm{ml}$. Hij vond geen correlatie tussen de bij cystometrie vastgestelde blaassensibiliteit enerzijds en de andere urodynamische aspecten anderzijds. Hij schreef dit toe aan de wisselende houding bij de verschillende onderzoekmethoden. Howard (1982) vond bij diabetici met neurogene blaasfunctiestoornissen zelfs een eerste aandrang bij een vulling boven de $1000 \mathrm{ml}$.

Salama Benarroch et al. (1979) vonden bij meer dan $50 \%$ van de onderzochte diabetici met een cystoneuropathie veranderingen van temperatuursensatie. Andersen en Bradley (1977) vonden deze meting onbetrouwbaar doordat sensibele prikkels ook afkomstig kunnen zijn uit structuren in de omgeving van de blaas. Een meer precieze methode voor het meten van de blaassensatie is de bepaling van de elektrische perceptiedrempel (Frimodt-Møller, 1972). Overtreft de elektrische perceptiedrempel de $15 \mathrm{~mA}$ dan wijst dit op een sensibiliteitsstoornis. Het nadeel is dat de test leeftijdsafhankelijk is en afwijkend kan zijn bij niet-diabetici met een infravesicale obstructie (Frimodt-Møller, 1976b). Bovendien is men bij deze methode ook afhankelijk van wat de patient aangeeft.

\subsubsection{UROFLOWMETRIE}

Deze methode dient om de hoeveeltheid en snelheid van de uitwendige urinestroom per tijdseenheid te meten. De meeteenheid is het geloosde volume per tijdseenheid (ml/sec). Door de onderzochte te laten urineren op een flowmeter kan de stroom van de urinestraal gemeten worden.

De uroflowmetrie maakt het mogelijk in angeveer $50 \%$ van de patienten een infravesicale abstructie te objectiveren (Coolsaet, 1983). Bij obstructieve prostaathypertrofie of urethrastrictuur zal de urinestroom afnemen, de mictieduur toenemen en kan de morfologie van de flowcurve eventueel een stootsgewijze mictie laten zien.

Uit de uroflowmetrie kunnen de volgende parameters worden afgeleid:

- maximale urinestroom (peak flow)

- mictieduur (duur van de flow)

- gemiddelde urinestroom (mean flow rate)

- het geloosde volume

- vorm of morfologie van het mictiegram.

De normale flowcurve toont aanvankelijk een snelle toename van de flow rate, waarbij de maximal flow rate binnen $1 / 3$ van de totale mictieduur wordt bereikt. Bij normale personen is de maximal flow rate voornamelijk afhankelijk van de leeftijd, het geslacht van de onderzochte en van het blaasvolume bij het begin van de mictie. De resultaten zijn ook afhankelijk van het type flowmeter en van de mate waarin de onderzochte in staat is urinelozing te onderdrukken.

Met zekere beperkingen kan de uroflowmetrie aangewend worden als screeningtest voor het aantonen of het uitsluiten van een infravesicale obstructie (prostaathypertrofie, urethrastrictuur, hyperactiviteit van het sphincterapparaat).

Deze beperkingen kunnen als volgt worden samengevat:

1. vals negatieve bevindingen kunnen gedaan worden als de blaas zich zo krachtig samentrekt, dat ondanks de aanwezigheid van een infravesicale obstructie een nor- 
male flow rate wordt geregistreerd. Eerst wanneer deze contracties zwakker (gewordenj zijn, zal men een insufficiënte flowcurve registreren

2. vals positieve bevindingen kunnen gedaan worden wanneer men te maken heeft met een hypotonie of atonie van de detrusor, zonder aanwezigheid van een infravesicale obstructie. Deze verzwakte detrusorcontractiliteit kan een uiting zijn van een neurogeen blaasilijden

3. vals positieve bevindingen kunnen ook gedaan worden wanneer bij afwezigheid van een infravesicale obstructie, een te actieve detrusor de blaas niet de kans geeft zich behoorlijk te vullen maar al snel tot evacuatie van de blaasinhoud over gaat. De evacuatie wan een gering volume leidt immers tot een geringe urinestroom. Deze hypertonie van de detrusor kan ook een uiting zijn van een neurogeen blaaslijden of van een zogenaamde 'unstable bladder'.

Om de bovengenoemide beperkingen te onderkennen zal men het meten van de urinestroam combineren met het simultaan registreren van de intravesicale druk gedurende de mictie. Bij een geringe flow zal een verhoogde intravesicale mictiedruk wijzen op een infravesicale obstructie.

Ondanks deze beperkingen sluit volgens Coolsaet (1983) een maximale flow hoger dan $15 \mathrm{~m} / \mathrm{sec}$ veelal een infravesicale obstructie uit.

\section{Bevindingen bij diabetici}

Bradley (1980), Howard (1982) en Frimodt-Møller (1976a) vonden twee typen flowcurves bii patienten met diabetes mellitus:

- lage maximale flow met verlengde duur, tesamen met een toename van het residu;

- verlengd intermitterend flowpatroon. Dit is een mictiepatroon gekenmerkt door korte onderbroken spurts van urine ten gevolge van mictie door abdominale druk.

Peak-flow waarden van $10 \mathrm{ml} / \mathrm{s}$ zijn bij diabetici niet ongewoon (Howard, 1982). Andersen en Bradley (1976) vonden bij 30 diabetici een gemiddelde flow van 5,8 m//s. De waarden varieerden van 2 tot $11 \mathrm{ml}$. Frimodt-Maller (1978) registreerde een flow van $13,6 \mathrm{ml} / \mathrm{s}$ (SD $5,7 \mathrm{ml} / \mathrm{s}$ ) bij 44 diabetici met een cystoneuropathie.

\subsubsection{URETHRADRUKPROFIEL}

Dit gedeelte van het urodynamisch onderzoek heeft voor ons onderwerp geen betekenis, omdat bij de diagnose van diabetische cystoneuropathie deze test geen diagnostische waarde heeft (Bradley, 1980; Howard, 1982).

\subsubsection{MICTIECYSTO-URETHROGRAM}

Het mictiecysto-urethrogram kan ook inlichtingen verstrekken bij de diagnostiek van het neurogeen blaaslijden, vooral indien het als een dynamisch onderzoek op een videoband wordt geregistreerd samen met de curves van de cystometrie, de flowmetrie en het elektromyogram (Whiteside, 1979).

\subsubsection{ELEKTROMYOGRAFIE}

Zoals op pagina 72 vermeld, vindt tijdens het urodynamisch onderzoek elektromyografisch onderzoek van de uitwendige sphincters plaats. Het EMG wordt hier uitsluitend verricht om een indruk te krijgen van de mate van aanspanning tijdens de vulling- en mictiefasen en heeft een ander karakter dan het onderzoek dat de klinisch-neurofysioloog pleegt le doen. In normale omstandigheden zal de sphincter zich bij stijgende vulling contraheren, om zich dan gedurende de mictie te ontspannen. 
Bif de neurogeen gestoorde blaas kan op deze wijze de zogenoemde detrusorsphincter-dyssynergie aangetoond worden. Hierbij ziet men in de mictiefase dat de sphincteractiviteit niet wegvalt, maar toeneemt met als gevolg een geringe flow. Beter nog kan dit syndroom aangetoond worden indien de bovengenoemde onderzoekmethoden gecombineerd worden met een simultaan mictiecysto-urethrogram.

De detrusorsphincter-dyssynergie is een verklaring voor de situatie waarbij een neurologisch gestoorde patient zonder mechanische infravesicale obstructie een hyperactieve detrusor met incontinentie vertoont en waarbij hij de blaas toch niet normaal kan ledigen. De coördinatie tussen de detrusorfunctie enerzijds en de functie van de dwarsgestreepte peri-urethrale musculatuur anderzijds is alleen mogelijk bij een ongestoorde centrale beînvloeding van detrusor en sphincter en een angestoorde functie op segmentaal niveau.

Bevindingen bij diabetici

Andersen en Bradley (1976) en Krane en Siroky (1979) beschreven een detrusorsphincterdyssynergie zowell met de dwarsgestreepte als met de gladde sphincter bij patienten met diabetes mellitus. Volgens hen komt dit bijna altijd bij myelumlaesies voor. De mate van dyssynergile komt overeen met de ernst van de beschadiging van het zenuwstelsel. 
DEEL Il:

EIGEN ONDERZOEK 


\section{HOOFSTUK 5 BESCHRIJVING ONDERZOCHTE GROEPEN}

\subsection{INLEIDING}

Op grond van de beschreven literatuur studies besloten wij zowel bij een referentiegroep als bij patienten met diabetes mellitus de volgende diagnostische onderzoekmethoden te verrichten:

EMG (zie 4.1.1.)

VAR (zie 4.1.2.)

BCR I en II (zie 4.1.3.)

Tibialis, pudendus, en pelvicus (hypogastricus) evoked potentials (zie 4.1.4.)

H-reflex (zie 4.1.5.)

De referentiegroep dient uitsluitend voor het verkrijgen van normaalwaarden van de klinisch-neurofysiologische methoden. De toegepaste urodynamische technieken zijn al gangbaar en gestandaardiseerd, zodat er geen behoefte was aan het verkrijgen van normaalwaarden hiervan.

Bij patienten met diabetes mellitus werden de volgende urologische onderzoekmethoden verricht: Cystoscopie (zie 4.2.2.)

Cystometrie (zie 4.2.3.)

Uroflowmetrie (zie 4.2.4.)

Urethradrukprofiel (zie 4.2.5.)

EMG (zie 4.2.7.)

Het EMG door de uroloog verricht heeft zoals eerder vermeld (zie 4.2.7.) een ander karakter als het EMG verricht door de klinisch-neurofysioloog.

\subsection{SAMENSTELLING REFERENTIEGROEP}

Daar het niet mogelijk was om willekeurige proefpersonen voor dit onderzoek te verkrijgen, werd aan patienten die de polikliniek neurologie bezochten en bij wie er geen aanwijzingen waren voor stoornissen op neurologisch, urologisch of gynaecologisch gebied, gevraagd om aan het onderzoek deel te nemen. Nagenoeg iedereen die gevraagd werd nam deel aan het onderzoek. In de jaren 1981-1982 werden 86 proefpersonen onderzocht.

De groep bestond uit:

16 personen met tendomyogene klachten van de nek 29 personen met tendomyogene klachten van de rug 41 personen met spanningshoofdpijn.

Dit waren 50 mannen en 36 vrouwen, de leeftijd varieerde van 15 tot 75 jaar, met een gemiddelde van 43,5 jaar. De leeftijd van de mannen varieerde van 29 tot 75 jaar (gemiddeld 48,2 jaar) en van de vrouwen wan 15 tot 73 jaar (gemiddeld 36,9 jaar). Voor de verdeling van de leeftijden bij mannen en vrouwen zie figuur 5.1 . 


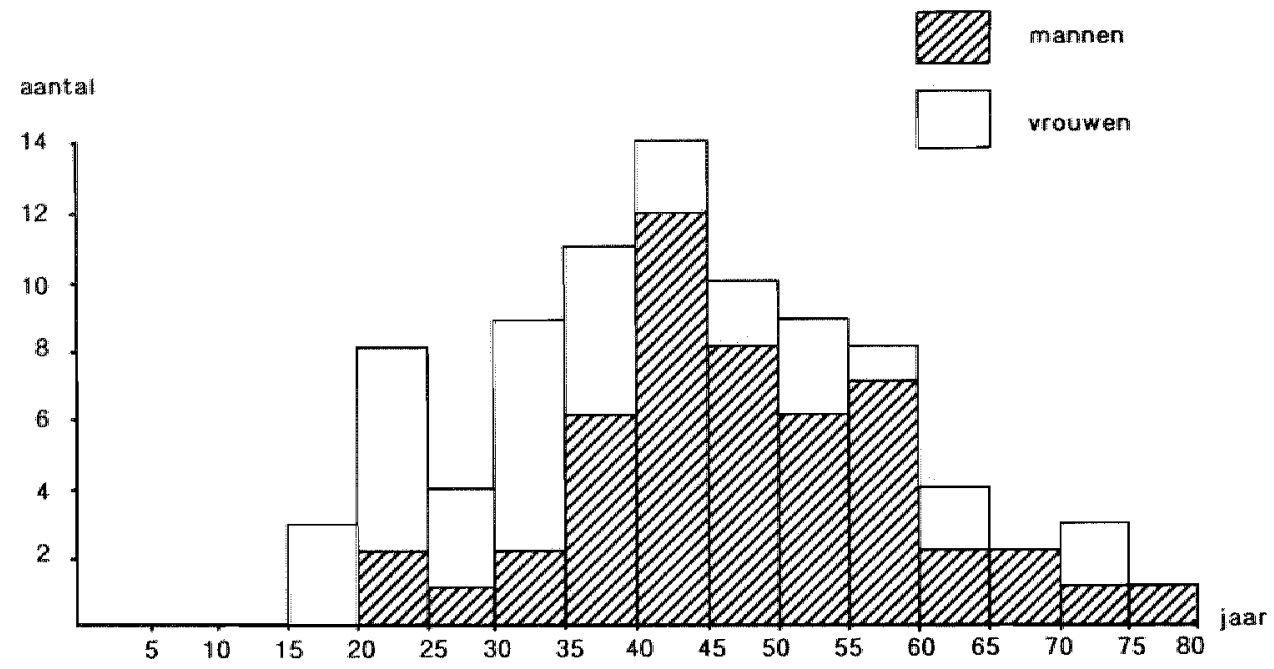

Figuur 5.1

Leeftijdsverclelling 50 mannen en 36 vrouwen uit de referentiegroep

\subsubsection{SPECIELE ANAMNESE}

Bij alle 86 personen zonder neurologische, urologische of gynaecologische afwijkingen werd een anamnese afgenomen en speciaal gevraagd naar stoornissen betreffende mictie, defaecatie en sexuele functies. Wat betreft de mictie werd gevraagd naar al of niet incontinent zijn en de aard ervan. Bovendien naar mictiedrang, passagegevoel, blaasontledigingsgevoel, grootte van de eerste ochtendplas en mictiefrequentie overdag en 's nachts. Alle proefpersonen konden aangeven dat mictiedrang, passagegevoel en blaasledigingsgevoel aanwezig waren. Twee personen hadden in het verleden anamnestisch over stress incontinentie geklaagd, doch hadden ten tijde van het onderzoek geen klachten. De mictiefrequentie was bij 72 personen 4 tot 5 porties per dag; 4 personen hadden een frequentie van 2 tot 3 porties per dag; 6 een frequentie tussen 6 en 8 porties per dag en 4 een frequentie van 10 porties per dag.

Bij 83 van de 86 onderzochten was er geen nycturie. Drie personen werden gemiddeld eenmaal per nacht wakker met mictiedrang.

De eerste ochtendplas was bij 83 personen bij navraag gelijk met de overige porties. Bij 1 persoon was deze groter en 2 personen wisten het niet.

Ook wat betreft het defaecatiepatroon werd gevraagd naar incontinentie, frequentie overdag en 's nachts, defaecatiedrang, passagegevoel en opluchtingsgevoel. Alle 86 onderzochten konden aangeven dat zij defaecatiedrang hadden, en zowel een passage- als een opluchtingsgevoel aanwezig waren.

84 Personen hadden overdag eenmaal een defaecatie en 2 personen tweemaal.

Geen van de proefpersonen had een nachtelijke defaecatie.

Slechts één van de personen had ten tijde van het onderzoek diarrhoea. 
80 Mannen en wrouwen konden aangeven dat libido aanwezig was.

46 Mannen hadden een normale erectie. Bij deze mannen was er ook een ejaculatie aanwezig. Geen van hen had een retrograde ejaculatie.

Het orgasme was bij 80 personen normaal aanwezig. Twee vrouwen en 4 mannen behorende tot de oudere leeftijdsgroep konden dit niet aangeven.

\subsubsection{AANVULLENDE ANAMNESTISCHE GEGEVENS}

Er werd gevraagd naar het gebruik van medicamenten en alcohol in verband met de mogelijke invloed hiervan op de \|atentietijden. Personen, die meer dan 10 glazen alcoholhoudende drank per week of meerdere medicamenten gebruikten werden niet toegellaten tot de referentiegroep.

Twee personen gebruikten een antihypertensivum en drie personen gebruikten een diureticum.

65 personen dronken geen of één glas alcoholhoudende drank per week; 18 tussen de 2 tot 7 glazen en drie dronken 8-10 glazen alcoholhoudende drank per week.

\subsubsection{NELIROLOGISCH ONDERZOEK}

Alle proefpersonen ondergingen een algemeen lichamelijk en neurologisch onderzoek. Wat betreft het neurologisch onderzoek werd specifiek gelet op motoriek, sensibiliteit (vitaal en gnostisch) en reflexen (met speciale aandacht voor de achillespeesireflexen en pathalogische reflexen).

Bij alle 86 personen werden bij neurologisch onderzoek geen afwijkingen gevonden. Allen hadden normale reflexen. Bij geen van de onderzochten werden pathologische reflexen gevonden.

Geen van de personen toonde bij neurologisch onderzoek tekenen van hypokinesie, ataxie, rigiditeit of tremor.

Drie personen hadden cardiovasculaire stoornissen. De overige 83 onderzochten hadden geen afwijkingen bij algemeen lichamelijk onderzoek.

\subsubsection{RONTGENDIAGNOSTIEK EN LABORATORIUMONDERZOEK}

Bij 66 proefpersonen werd de lumbosacrale wervelkolom röntgenologisch onderzocht. $\mathrm{Bij}$ 53 onderzochten werden geen afwijkingen gevonden. Bij 13 onderzochten (20\%) waren er afwijkingen in de zin van spina bifida, lichte discopathie en/ol spondylarthrosis.

Bij 80 van de 86 personen werd in het serum het ureumgehalte bepaald. Dit was bij 78 personen $(97,5 \%)$ normaal met een waarde $<7 \mathrm{mmol} / \mathrm{l}$. Twee personen hadden een ureum van $9 \mathrm{mmol} / \mathrm{l}$. Het kreatininegehalte in het serum werd bij 84 personen bepaald en was bij allen normaal. De spreiding was $58-129 \mathrm{mmol} / \mathrm{l}$.

Bij alle 86 personen was het serumglucosegehalte beneden de $5,9 \mathrm{mmol} / \mathrm{l}$. Het urinesediment had bij 85 personen geen afwijkingen en werd bij 1 persoon niet bepaald.

\subsubsection{LENGTE PROEFPERSONEN}

Bij 85 personen werd de lichaamslengte gemeten. (tabel 5.1) 
Lengte proefpersonen $\mathrm{N}$

Spreiding lengte totale groep

Gemiddelde lengte totale groep

85

85

Spreiding lengte mannen

Gemiddelde lengte mannen

Spreiding lengte vrouwen

Gemiddelde lengte vrouwen
49

49

36

36
$142-192 \mathrm{~cm}$ $167,2 \mathrm{~cm}(\mathrm{SD} 8,8 \mathrm{~cm})$

$152-192 \mathrm{~cm}$ $171.5 \mathrm{~cm}(\mathrm{SD} 7,5 \mathrm{~cm})$

$142-174 \mathrm{~cm}$ $161,0 \mathrm{~cm}(\mathrm{SD} 6,4$ $(\mathrm{cm})^{* *}$

* $\mathrm{P}<0,001$

\subsection{SAMENSTELLING PATIENTENGROEP}

De patientengroep werd samengesteld uit patienten die de polikliniek neurologie van de ziekenhuizen te Sittard en Gelleen bezochten, en bij wie de diagnose diabetes mellitus was of werd gesteld. Dit gebeurde volgens de criteria van de American Diabetes Association (Genuth, 1982). Deze diagnose werd door de internist gesteld op grond van anamnese en laboratorium onderzoek, o.a. een verhoogde nuchtere bloedsuiker (normaalwaarde $3,9-5,9 \mathrm{mma} / \mathrm{l} / \mathrm{l}$ ). Indien echter de nuchtere bloedsuiker verhoogd was, doch beneden de $7,8 \mathrm{mmol} / \mathrm{I}$, werd bij een verdachte anamnese een GTT verricht. Slechts de patienten met een diabetische GTT werden toegelaten. Criterium hiervoor was een serumglucose boven de $11,1 \mathrm{mmol} / \mathrm{l}$ twee uur na de glucosetoediening.

Patienten met een gestoorde GTT, dat wil zeggen een nuchter serumglucose beneden de $7 \mathrm{mmol} / \mathrm{l}$ en een maximum boven of gelijk aan $11,0 \mathrm{mmol} / \mathrm{l}$ en met een twee-uurs-waarde tussen 8 en $11 \mathrm{mmol} / \mathrm{l}$ werden niet toegelaten tot het onderzoek.

Tijdens de test en enkele dagen tevoren mochten geen medicamenten toegediend worden, zoals diuretica, orale contraceptiva, glucocorticoiden, nicotinezuur, phenytoine, tricyclische antidepressiva, MAO remmers, lithium, izoniazide en indomethacine.

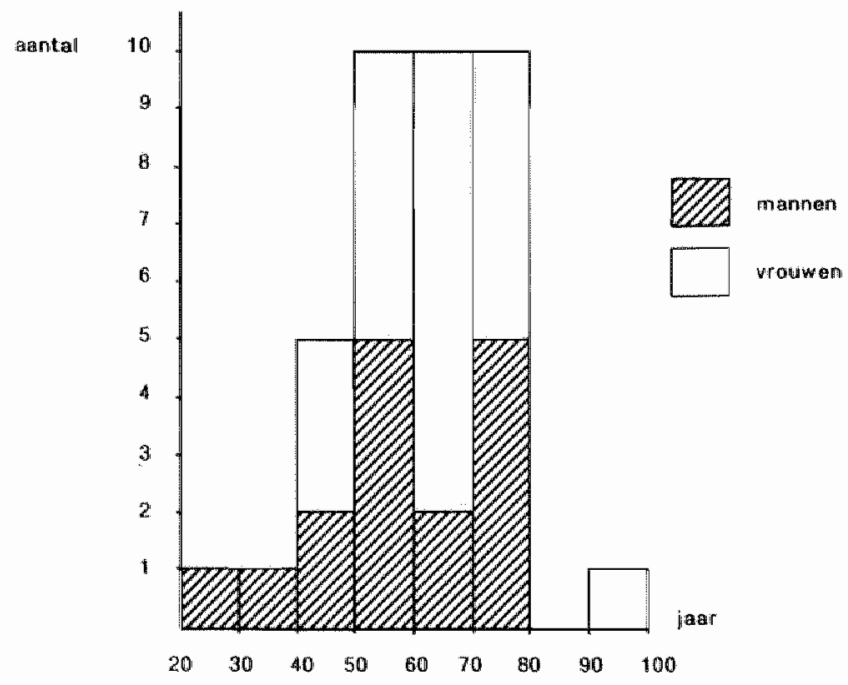

Figuur 5.2

38 insuline afhankelijke diabetici.

Leeftijdsverdeling bij 80 patienten met diabetes mellitus. 
De insuline afhankelijke diabetes mellitus werd behandeld met insuline en dieet en de niet insuline afhankelijke diabetes mellitus met sulfonylureum derivaten en dieet of alleen dieet.

Op deze wijze werd in de jaren $1982 \mathrm{t} / \mathrm{m} 1984$ een groep van 80 patienten met diabetes mellitus verkregen. De patientengroep bestond uit 34 mannen en 46 vrouwen met een leeftijd die varieerde van 28 tot 91 jaar, met een gemiddelde van 60,9 jaar (figuur 5.2 en 5.3).
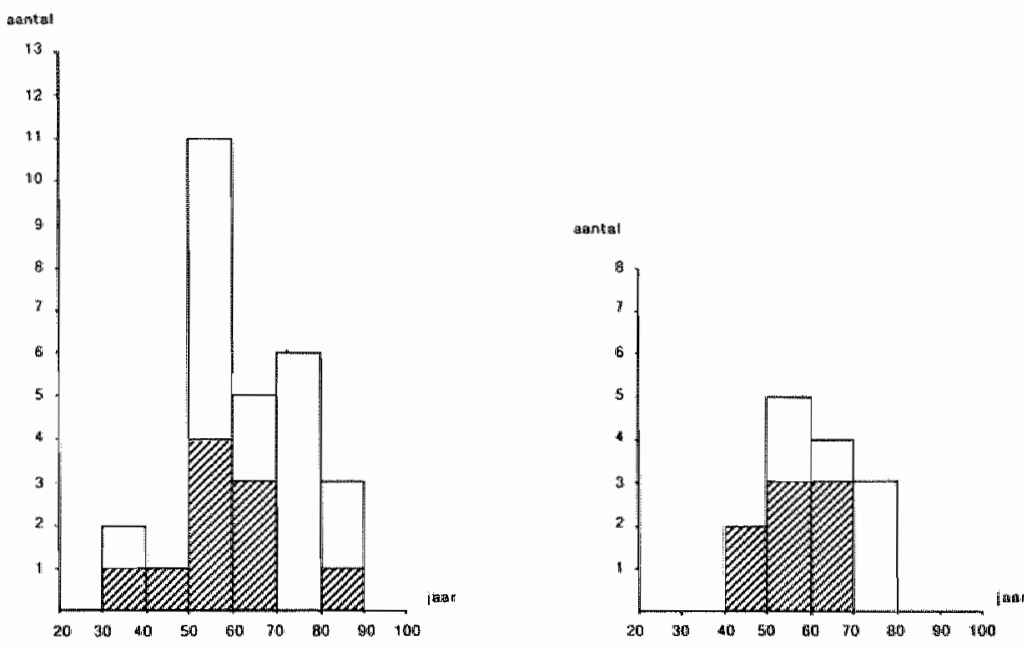

Figuur 5.3

28 patienten met orale antidiabetica

14 patienten met alleen dieët

38 Patienten uit deze groep waren insuline afhankelijk en gebruikten naast wisselende hoeveelheden insuline ook een suikerarm dieet. 42 patienten waren niet insuline afhankelijk en hiervan gebruikten 28 patienten orale antidiabetica in verschillende combinaties en wisselende hoeveellheden, en bovendien een suilkerarm dieet. 14 patienten werden alleen met een suikerarm dieet behandeld.

De duur van de diabetes mellitus varieerde van 1 maand tot 38 jaar.

De reden van verwijzing wordt weergegeven in tabel 5.2 .

Tabel 5.2

Reden van verwijzing

Urine incontinentie

Urineretentie

Sexuele functiestoornissen

Incontinentie of retentie +

sexuele functiestoornissen

Sensibiliteitsstoornissen

Geen klachten, d.w.z. geen

relatie met diabetes mellitus

$\begin{array}{rlr}11 & (1 \text { man en 10 vrouwen) } & 14 \% \\ 5 & (1 \text { man en 4 vrouwen) } & 6 \% \\ 3 & \text { (3 mannen) } & 4 \% \\ 5 & (5 \text { mannen }) & 6 \% \\ 47 & \text { (20 mannen en 27 vrouwen) } & 59 \% \\ 9 & \text { (4 mannen en 5 vrouwen) } & 11 \%\end{array}$

De duur van deze klachten varieerde van 1 maand tot 25 jaar en bij één patient zelfs 41 jaar. 
Bij alle 80 mannelijke en wrouwelike diabefici werd in de anamnese speciaal gevraagd naar stoornissen betreffende mictie, defaecatie en sexuele functies.

Wat betreft de mictie werd gevraagd naar mictiefrequentie overdag en 's nachts, incontirientie en de aard ervan (tabel 5.3), drang, passagegevoel, blaasledigingsgevoel (tabel 5.4) en de grootte van de eerste ochtendplas.

De mictiefrequentie overdag varieerde bij 77 diabetici van 2 tot 20 maal per dag. Drie patienten konden de mictiefrequentie niet aangeven. 54 patienten hadden een nachtelijke mictiefrequentie van 1 tot 5 maal en vier patienten hadden een nachtelijke mictie, doch konden de frequentie niet aangeven. 22 patienten hadden geen nycturie.

Wij spraken van stress incontinentie indien bij een patient urineverlies optrad na lichamelijke inspanning of wanneer bij een patient urineverlies optrad bij verhoging van de intraabdominale druk.

Van urge incontinentie spraken wij bij onwillekeurig urineverlies dat gelijktijdig gepaard ging met een sterke niet te onderdrukken drang tot urinelozing en van urgency als aandrang tot urinelozing aanwezig was, die echter, zij het soms met moeite, kunstmatig te onderdrukken was.

In tabel 5.3 en 5.4 wordt frequentie van voorkomen van de aard van de urine incontinentie en drang, passage- en blaasledidigingsgevoel weergegeven.

Tabel 5.3

Aard van de urine incontinentie

stress incontinentie

urge incontinentie + urgency 29

geen uncontinentie

$46 \quad(58 \%)$

Tabel 5.4

Drang, passage-, blaasledigingsgevoel

$\begin{array}{llll} & \text { geen } & \text { intact } & \text { totaal } \\ \text { Drang } & 14(18 \%) & 66(82 \%) & 80 \\ \text { Passagegevoel } & 11(14 \%) & 69(86 \%) & 80 \\ \text { Blaasledigingsgevoel } & 13(16 \%) & 67(84 \%) & 80\end{array}$

Alle patienten konden aangeven of er wel of geen drang, passage- of blaasledigingsgevoel aanwezig was. 14 patienten meldden dat zili geen drang hadden, 11 patienten geen passagegevoel en 13 geen blaasledigingsgevoel.

De eerste ochtendplas was bij 14 patienten gelijk aan de overige porties. Bij 26 patienten was deze groter, bij één patient kleiner. 37 patienten konden dit niet duildelijk aangeven. Ook bij de defaecatie werd gevraagd naar incontinentie, frequentie overdag en 's nachts, drang, passagegevoel en opluchtingsgevoel. De frequentie varieerde van 1 tot 4 maal per dag. Twee patienten hadden een nachtelijke defaecatie. Vier patienten waren alleen in perioden met diarrhoea incontinent. 
Voor de frequentie van voorkomen van drang, passage- en opluchtingsgevoel bij defaeca. tie zie tabel 5.5 .

\section{Tabel 5.5}

Drang, passage- en opluchtingsgevoel bij defaecatie

$\begin{array}{llll} & \text { geen } & \text { intact } & \text { totaal } \\ \text { Drang } & 3(4 \%) & 77(96 \%) & 80 \\ \text { Passagegevoel } & 1(1 \%) & 79(99 \%) & 80 \\ \text { Opluchtingsgevoel } & 3(4 \%) & 77(96 \%) & 80\end{array}$

Bij de drie patienten met afwezige defaecatiedrang was ook het opluchtingsgevoel afwezig en bij één van deze patienten ook het passagegevoel. Twee patienten uit deze groep hadden ook een afwezige mictiedrang.

\section{Libido}

27 Van de 34 onderzochte mannen met diabetes mellitus gaven aan dat libido aanwezig was. Bij vier patienten was dit afwezig. Drie oudere mannelijke patienten konden dit niet aangeven.

Bij de vrouwelijke diabetici konden 19 van de 46 onderzochten aangeven dat libido aanwezig was. Bij vijf patienten was dit gevoel afwezig en 22, voornamelijk oudere patienten, hadden geen mening (tabel 5.6).

\section{Tabel 5.6}

\section{Libido}

$\begin{array}{lllcl} & \text { geen } & \text { intact } & \text { onbekend } & \text { totalal } \\ \text { mannen } & 4(12 \%) & 27(79 \%) & 3(9 \%) & 34 \\ \text { vrouwen } & 5(11 \%) & 19(41 \%) & 22(48 \%) & 46\end{array}$

\section{Erectie}

Bij 21 van de 34 onderzochte mannelijke diabetes mellitus patienten ontbrak de erectie. Bij 11 patienten was deze aanwezig en twee patienten hadden geen mening (tabel 5.7).

\section{Tabel 5.7}

\section{Erectie}

$\begin{array}{lllll} & \text { geen } & \text { intact } & \text { onbekend totaal } \\ \text { erectie } & 21(62 \%) & 11(32 \%) & 2(6 \%) & 34\end{array}$




\section{Ejaculatie}

22 Manren van de 34 onderzochte diabetici hadden een ejaculatie. Bij tien van hen ontbrak dit en twee patienten konden dit niet aangeven.

28 Van de 34 onderzochte diabetici hadden geen retrograde ejaculatie en zes patienten hadden hier geen duidelik idee over (tabel 5.8).

Tabel 5.8

Ejaculatie

$\begin{array}{lllll} & \text { geen } & \text { intact } & \text { anbekend totaal } \\ \text { ejaculatie } & 10(29 \%) & 22(65 \%) & 2(6 \%) & 34 \\ \text { retrograde ejaculatie } & 28(82 \%) & - & 6(18 \%) & 34\end{array}$

\section{Orgasme}

Het gevoel van argasme was bij 25 mannelijke patienten aanwezig, bii zes afwezig en drie hadden geen mening.

Bij de 46 vrouwelijke patienten hadden 15 patienten het gevoel van een orgasme. Bij acht patienten ontbrak dit gevoel en 23 patienten hadden geen mening (tabel 5.9).

\section{Tabel 5.9}

Orgasme

$\begin{array}{lllcl} & \text { geen } & \text { intact } & \text { onbekend } & \text { totaal } \\ \text { mannen } & 6(18 \%) & 25(73 \%) & 3(9 \%) & 34 \\ \text { vrouwen } & 8(17 \%) & 15(33 \%) & 23(50 \%) & 46\end{array}$

Naast de speciele anamnese betreffende mictie, defaecatie en sexuele functies werd ook een algemene anamnese afgenomen. 24 patienten hadden cardiovasculaire stoornissen en 5 patienten gastro-intestinale klachten.

\subsubsection{AANVULLENDE ANAMNESTISCHE GEGEVENS}

13 Patienten gebruikten naast de antidiabetische behandeling een antihypertensivum en één patient twee antihypertensiva. 24 patienten gebruikten een diureticum en 10 patienten namen een middel met een anticholinergische werking of bijwerking.

Het alcoholgebruik varieerde van 1 tot 10 glazen alcoholhoudende drank per week. Twee patienten gebruikt 15 glazen per week.

\subsubsection{NEUROLOGISCH ONDERZOEK}

Bij het algemeen neurologisch onderzoek werd speciaal gelet op motoriek, sensibiliteit (vitaal en gnostisch), reflexen met specialle aandacht voor de achillespeesreflexen en het al of niet aanwezig zijn van een pathologische voetzoolreflex. 
Bil 63 van de onderzochte diabetes mellitus patienten waren bij neurologisch onderzoek één of beide achillespeesreflexen verlaagd of afwezig.

Bij twee patienten werd een pathologische voetzoolreflex (VZA) gevonden.

\section{Sensibiliteit (vitaal en gnostisch)}

39 Patienten hadden bij neurologisch onderzoek vitale (met of zonder gnostische) en 60 patienten gnostische (met of zonder vitale) sensibiliteitsstoornissen.

\section{Krachtsvermindering}

41 Mannelijke en vrouwelijke diabetici toonden bij neurologisch onderzoek krachtsvermindering in één of meer spieren van armen en/of benen in verschillende gradaties.

Voor een overzicht van deze gegevens zie tabel 5.10 .

Tabel 5.10

Bewindingen bij neurologisch onderzoek

\begin{tabular}{lccl} 
& normaal & pathologisch & totaal \\
Achillespeesreflexen & $17(21 \%)$ & $63(79 \%)$ & 80 \\
Pathologische VZR & $78(98 \%)$ & $2(2 \%)$ & 80 \\
Sensibiliteitsstoornissen: & & & \\
Vitaal & $41(51 \%)$ & $39(49 \%)$ & 80 \\
Gnostisch & $20(25 \%)$ & $60(75 \%)$ & 80 \\
Krachtsvermindering & $39(49 \%)$ & $41(51 \%)$ & 80 \\
\hline
\end{tabular}

Hypotonie, rigiditeit en tremor

Vijf patienten toonden bij neurologisch onderzoek rigiditeit en een tremor. Vier van deze patienten waren in meer of mindere mate hypokinetisch.

Ataxie

Een ataxie door middel van vinger-neus-proef of knie-hak-proef getest, was in meer of mindere mate aanwezig bij drie patienten.

\section{Overige autonome stoornissen}

Een hypo- en anhydrose werd bij zeven patienten gevonden en oesophagale dysfunctie (door middel van slikfoto's vastgesteld) bij eveneens zeven patienten. Twee patienten toonden cardiovasculaire stoornissen, die toegeschreven konden worden aan een autonome neuropathie. Eén patient had orthostatische hypotensie en vier patienten hadden diarrhoea.

\subsubsection{RÖNTGENDIAGNOSTIEK EN LABORATORIUMONDERZOEK}

Bij alle patienten werd de lumbosacrale wervelkolom röntgenologisch onderzocht. Bil 31 van de 86 onderzochten $(36 \%$ ) waren er afwijkingen in de zin van spina bifida, lichte discopathie en/of spondylarthrosis.

Zes patienten hadden een verhoogd kreatinine, variërend van 131 tot $527 \mathrm{mmol} / \mathrm{l}$, waarvan twee ernstig (450 en $527 \mathrm{mmol} / \mathrm{l})$. 28 patienten hadden een verhoogd ureum variërend van 8 tot $36 \mathrm{mmol} / /$, waarvan twee ernstig (resp. 30 en $36 \mathrm{mmol} / \mathrm{l}$ ). 


\section{METHODEN VAN ONDERZOEK \\ EN ONDERZOEKRESULTATEN}

\subsection{KLINISCH-NEUROFYSIOLOGISCH ONDERZOEK BIJ REFERENTIE- EN PATIENTENGROEP}

\subsubsection{ELEKTROMYOGRAFISCH ONDERZOEK M. SPHINCTER ANI EXTERNUS}

\subsubsection{METHODE}

$\mathrm{Na}$ reiniging van de peri-anale huid met een steriele zoutoplossing $(\mathrm{NaCl} 0,9 \%)$ werd een concentrische naaidelektrode in de $\mathrm{m}$. sphincter ani externus geplaatst. Bij 20 van de 86 personen uit de referentiegroep en bij eveneens 20 van de 80 personen uit de patientengroep werd de spier beiderzijds onderzocht; bij alle overigen vond het onderzoek alleen rechts plaats.

De spieraktiviteit werd zichtbaar gemaakt op het oscilloscoopscherm van een EMG toestel en semikwantitatief geëvalueerd (tabel 6.1). Het aanspanningspatroon van de $\mathrm{m}$. bulbocavernosus werd niet gekwantificeerd.

Tabel 6.1

Semikwantitatieve evaluatie spieractiviteit $m$. sphincter ani externus

basisaktiviteit:

spontane spiervezelpotentialen

maximaal aanspanningspatroon:
1. gemengd patroon

2. ruim enkelvoudig patroon

3. licht enkelvoudig patroon

4. geen aktiviteit

1. ja

2. nee

3 niet te beoordelen

1. interferentiepatroon

2. ruim gemengd patroon

3. licht gemengd patroon

4. enkelvoudig patroon

5. geen aktiviteit

Onder basisaktiviteit wordt verstaan de spontane motorunitaktiviteit (MU-aktivitelit) die in deze sluitspier aanwezig blijft nadat onderzochte gedurende enige tijd zoveel mogelijk tot ontspanning is glebracht. Beoordeling vond plaats 30 a $60 \mathrm{~s}$ na naaldinsertie.

Om de eventuele spontane spiervezelaktiviteit voldoende te kunnen beoordelen werd getracht de $\mathrm{m}$. sphincter ani externus zoveel mogelijk tot ontspanning te brengen door onderzochte te vragen te persen als bij defaecatie. 


\section{Q1.1.2. RESULTATEN}

De voornaamste onderzoekresultaten worden getoond in tabel 6.2 .

Tabel 6.2

Naald-EMG m. sphincter ani externus

$\begin{array}{ll}\text { Referentie- } & \text { Patienten- } \\ \text { groep } & \text { groep } \\ (n=86) & (n=80)\end{array}$

Basisaktiviteit
gemengd
ruim enkelvoudig
licht enkelvoudig
geen aktiviteit

0

$14(16 \%)$

$70(82 \%)$

$2(2 \%)$

$1(1 \%)$

$8(10 \%)$

$58(73 \%)$

$13(16 \%)$

$11(14 \%)$

$(n=78)$

complexe repetitieve ontladingen

$5(6 \%)$

$(n=79)$

Maximaal aanspanningspatroon

interferentie

ruim gemengid

licht gemengd

enkelvoudig

geen aktiviteit

$\begin{array}{rr}84(98 \%) & 35(44 \%) \\ 2(2 \%) & 35(44 \%) \\ 0 & 6(7 \%) \\ 0 & 4(5 \%) \\ 0 & 0\end{array}$

Doordat de basisaktiviteit niet voldoende was te reduceren was de aanwezigheid van fibrillatiepotentialen niet voldoende te beoordelen bij 7 proefpersonen en 2 patienten. De fibrillatiepotentialen werden in alle gevallen bij die patienten gevonden waarbij de spontane motorunitaktiviteit in de $\mathrm{m}$. sphincter ani externus ontbrak. Complexe repetitieve ontladingen werden bij de referentiegroep in de $\mathrm{m}$. bulbocavernosus niet geregistreerd.

Er bleek een duidelijke relatie te bestaan tussen de mate van spontane MU-aktiviteit en het maximale aanspanningspatroon. Van de 13 patienten zonder MU-aktiviteit bereikte

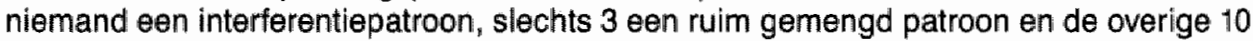
een enkelvoudig of licht gemengd patroon. Bij 1 patient was geen toename van de MU-aktiviteit bij poging tot maximale aanspanning.

\subsubsection{DISCUSSIE}

\section{Basisaktiviteit}

Overeenkomstig de literatuur (Beck, 1930; Kawakami, 1954; Taverner en Smiddy, 1959) was er bij alle controlepersonen bij insertie en in een periode van tenminste $60 \mathrm{~s}$ daarna spontane MU-aktiviteit aanwezig. Het ontbreken daarvan bij $16 \%$ van de diabeten is dus een duidelijk teken van gestoorde innervatie van de $\mathrm{m}$. sphincter ani externus. Ook overigens is het spontane aanspanningspatroon bij de diabetici gemiddeld minder dicht dan bij de controlegroep. Dit komt overeen met opgaven in de literatuur (Fagerberg et al., 1967). 
Opvallend is het voorkomen in de referentiegroep van complexe repetitieve ontladingen bij 5 personen terwijl deze in de patientengroep ontbreken. Mededelingen over het voorkomen van dergelịke aktiviteit in de normale $\mathrm{m}$. sphincter ani externus ontbreken in de literatuur. Wel is zij beschreven in de normale $\mathrm{m}$. sphincter urethrae externus (Trontell on Stolberg, 1983; Fowler, 1985). Overigens wordt het voorkomen van fibrillatiepotentialen in de $\mathrm{m}$. sphincter ani externus door Bradley (1980) niet als evident pathologisch beschouwd. Als gevolg van defaecatieproblemen worden volgens hem de motorische zenuwtakjes in de spier vaak beschadigd. Toch valt in onze studie op dat fibrillatiepotentialen bij $14 \%$ van de diabeten voorkwamen en niet bij de controlegroep. Fagerberg (1969) vond bij 20 diabetici geen fibrillatiepotentialen in de $\mathrm{m}$. sphincter ani externus en in een aantal door hem onderzochte bekkenbodemspieren.

Overigens moet bij dit onderzoek worden bedacht dat de kans op het vinden van fibrillatiepotentialen toeneemt naarmate de spier uitgebreider wordt onderzocht. Gelet op het totaal van de onderzoekingen hebben we ons in deze studie beperkt tot meestal slechts 1 insertie terwijl bij 20 controlepersonen en 20 diabetici 2 punten van de spier werden onderzocht (één links en één rechts).

Het feit dat fibrillatiepotentialen altijd werden gevonden in die spieren die geen MUaktiviteit vertonen maakt het extra aannemelijk dat de bevinding als pathologisch moet worden beschouwd.

Vrijwel alle proefpersonen konden bij poging tot maximale aanspanning een interferentiepatroon bereiken. Het onvermogen om tenminste een ruim gemengd aanspanningspatroon te verkrijgen is klaarblijkelijk pathologisch. De 10 patienten waarbij dat het geval was behoorden allen tot de groep waarbij spontane MU-aktiviteit ontbrak en waarbij fibrillatiepotentialen werden gevonden. De ene patient waarbij de MU-aktiviteit bij poging tot maximale aanspanning niet toenam had spontaan een ruim enkelvoudig patroon. Ook Waylonis en Powers (1972) vonden bij een deel van de door hen onderzochte diabetici (14\%) een onvoldoende dichtheid van het patroon bij maximale aanspanning in de $\mathrm{m}$. sphincter anil externus.

Welke de mogelijke betekenis is van bovenstaande bevindingen in het kader van de urogenitale stoornissen bij de diabetici wordt besproken in hoofdstuk 7.

\subsubsection{ONDERZOEK VAN DE VESICO-ANALE-REFLEX (VAR)}

\subsubsection{METHODE}

Een Foley silicone katheter van 12 French van het type Browne met twee oppervlakteelektroden op 2 en $3,5 \mathrm{~cm}$ van de onderkant van de ballon werd door een ervaren verpleegkundige ingebracht. Nadat de blaas via de catheter was geledigd werd de ballon gevuld met $4 \mathrm{mi}$. fysiologische zoutoplossing, waarna de katheter werd teruggetrokken tot de elektroden in contact kwamen met de mucosa van het meest proximale deel van de urethra. Voor elektrische stimulatie en voor registratie van de respons werd gebruik gemaakt van een EMG toestel.

Over het algemeen werd gebruilk gemaakt van ca. 10 enkelvoudige rechthoekstimuli met een duur van 0,1 of $0,2 \mathrm{~ms}$ (soms $0,5 \mathrm{~ms}$ ) met een amplitudo van 100 tot $300 \mathrm{~V}$. Deze werden met tussenpozen van meerdere seconden toegediend. Er werd gestimuleerd met een prikkel van toenemende amplitudo en duur tot een maximalle respons werd verkregen. Alleen responsen na supramaximale stimulatie en responsen die tenminste $2 x$ reproduceerbaar waren werden geaccepteerd. De prikkels bleven hierbij onder de pijndrempel. Soms waren bij patienten met diabetes mellitus korte stimulustreintjes nodig om een maximale respons te verkrijgen.

Afgeleid werd met een concentrische naaldelektrode meestal ingebracht in het rechter 
deel van de m. sphincter ani externus (zie 6.1.1.1.). Om te onderzoeken of de latentietijd verschillend was bil registratie uit de $\mathrm{m}$. sphincter ani externus en $\mathrm{m}$. bulbocavernosus werd bil een deel van de onderzochten de concentrische naaldelektrode ook in de $\mathrm{m}$. bulbocavernosus geplaatst, bij mannen achter het scrotum dichtbij de raphe perinei ingebracht en bij vrouwen aan de rechter zijde van het voorste deel van de commissura labiorum posterior. Om te bevestigen dat de elektrode zich daadwerkelijk in de $\mathrm{m}$. bulbocavernosus bevond was het nodig de spier te laten aanspannen door onderzochte te laten kuchen of onderzochte licht te laten knijpen in de glans penis.

Het reflexantwoord werd in beide spieren gelijktijdig geregistreerd. Een aardelektrode in de vorm van een plaat werd onder de nates van de onderzochte geplaatst.

Bij registratie van de respons werd een laag afsniffilter van $32 \mathrm{~Hz}$ ( 3 dB/octaaf) en een hoog afsniifilter van $3200 \mathrm{~Hz}$ (6 dB/octaaf) gebruikt. De tijdbasis was 10 tot $30 \mathrm{~ms} / \mathrm{div}$ en de gevoeligheid van de versterker 50 tot 100 uV/div.

De registratie van het reflexantwoord vond op verschillende wijzen plaats:

1. vastgehouden in de storage van de 'signal delay unit'

2. in 'raster mode' op UV film

3 . in 'super Imposed mode' op UV film

4. door averaging van een tiental responsen.

Bij toename van de intensiteit en duur van de stimulus nam de latentietijd van de respons af, terwijl hierbij de duur en de amplitudo van de respons toenamen tot een maximale waarde. De duur van de respons varieerde van ca. 30 tot ca. $500 \mathrm{~ms}$. De amplitudo varieerde van ca. 50 tot ca. $1000 \mathrm{uV}$ en was soms nog hoger. De vorm en latentietijd waren niet verschillend bij registratie uit beide zijden van de $\mathrm{m}$. sphincter ani externus (20 proefpersonen).

Bij een verlengde latentietijd was de duur van de respons vaak korter en de amplitudo meestal verlaagd.

De latentietijd van de VAR bij registratie uit de $\mathrm{m}$. sphincter ani externus was niet afhankelijk van de leeftijd. 


\subsubsection{RESULTATEN}

De voornaamste onderzoekresultaten worden getoond in tabet 6.3 en figuren $6.1 \mathrm{t} / \mathrm{m} 6.8$.

Tabol 6.3

Latentietijden VAR ( $m$. sphincter ani externus en $m$. bulbocavernosus)

bij referentio- en patientengroep

Referentie- Patienten-

groep groep

m. sphincter ani externus

Totaal

Niet opwekbaar

Spreiding latentietijden

Gemiddelde waarde

biij mannen en vrouwen

mannen

$\begin{array}{lll}N & 86 & 80 \\ N & - & 3\end{array}$

vrouwen

$N$

44-77 ms $\quad 50-118 \mathrm{~ms}$

N

$60,8 \mathrm{~ms} \quad 74,3 \mathrm{~ms}^{* *}$

(SD 7,1 ms) (SD 14,3 ms)

$50 \quad 34$

$61,0 \mathrm{~ms} \quad 73,7 \mathrm{~ms}$ **

(SD 7,6 ms) (SD 15,0 ms)

$36 \quad 43$

$60,6 \mathrm{~ms} \quad 74,7 \mathrm{~ms}$ *

(SD 7,4 ms) (SD 13,8 ms)

Afwezige of vertraagde

VAR ( $>$ gemiddelde $+2 S D$ )

N

$37(46 \%)$

m. bulbocavernosus

Totaal

Niet opwekbaar

Spreiding latentietijden

Gemiddelde waarde

bij mannen en vrouwen

mannen

$\begin{array}{lll}N & 25 & 17\end{array}$

$\mathrm{N} \quad 3$

50-76 ms $\quad 43-106 \mathrm{~ms}$

$\begin{array}{ll}63,9 \mathrm{~ms} & 69,8 \mathrm{~ms} \\ \text { (SD } 7,9 \mathrm{~ms}) & \text { (SD 18,4 ms) }\end{array}$

N 12

5

$62,2 \mathrm{~ms} \quad 76,4 \mathrm{~ms}$

(SD 9,2 ms) (SD 27,8 ms)

vrouwen

$\mathbb{N}$

13

9

$65,5 \mathrm{~ms} \quad 66,1 \mathrm{~ms}$

(SD 6,4 ms) (SD 10,9 ms)

Afwezige of vertraagde

VAR ( $>$ gemiddelde +2SD)

N

$6(35 \%)$

***P $<0,001$

De individuele waarden werden door ons als afwijkend beschouwd indien zij hoger waren dan hett gemiddelde $+2 S D$.

Wij slaagden slechts bij 5 proefpersonen erin de respons te laten verdwijnen bij poging tot relaxatie. 

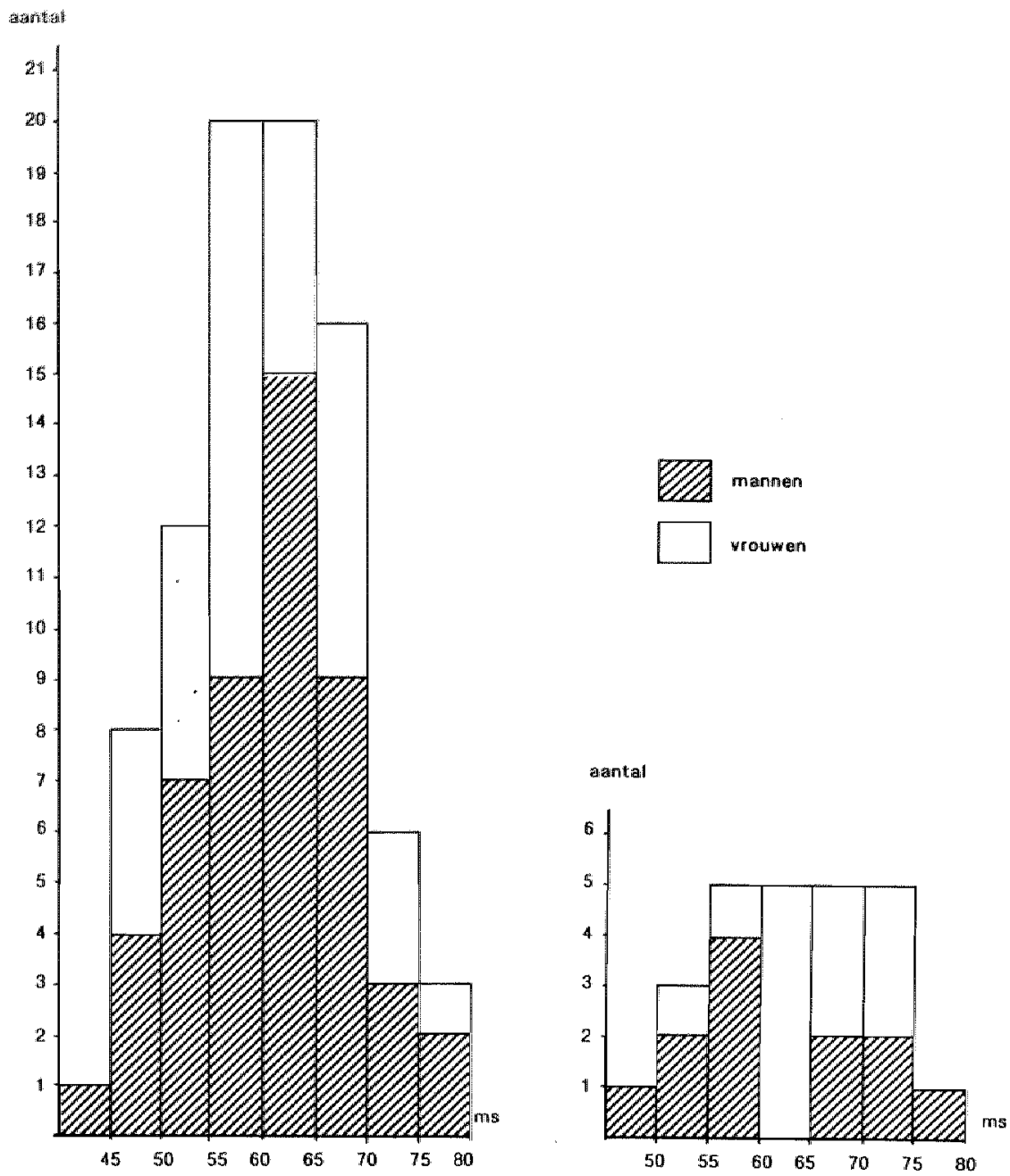

Figuur 6.1

Latentietijden VESICO-ANALE-REFLEX $\mathrm{m}$. sphincter ani externus referentiegroep 50 mannen/36 vrouwen
Figuur 6.2

Latentietijden VESICO-ANALE-REFLEX $\mathrm{m}$. bulbocavernosus referentiegroep 12 mannen/13vrouwen 


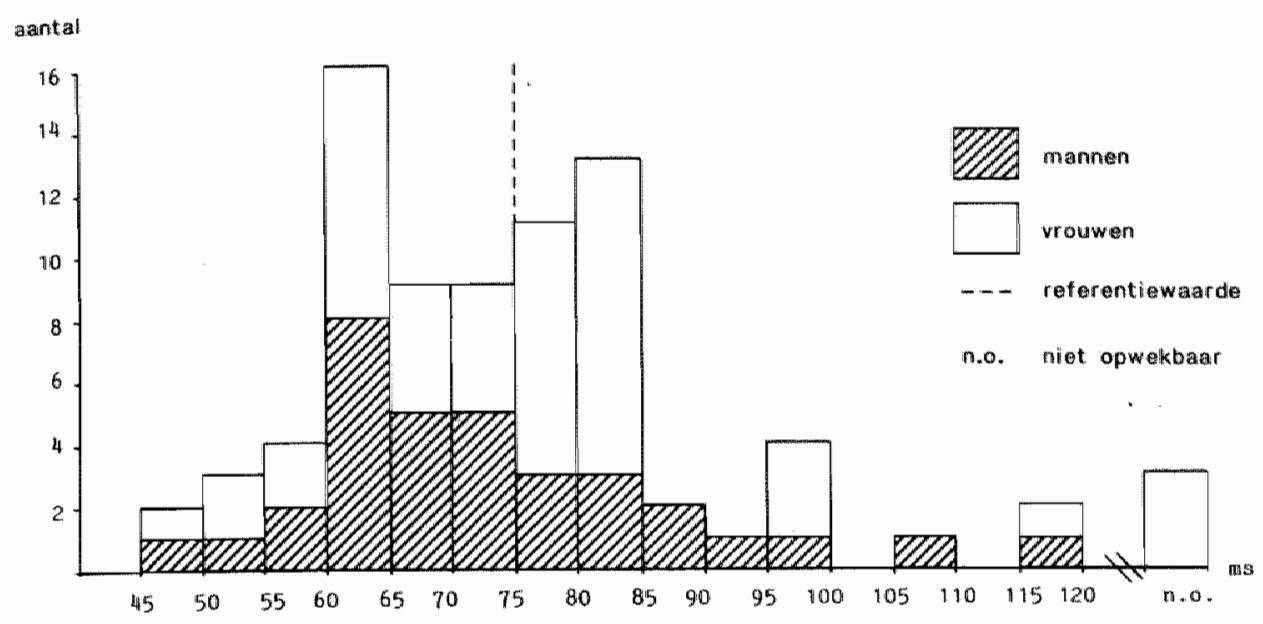

Figuur 6.3

Latentietijden VESICO-ANALE-REFLEX $\mathrm{m}$. sphincter ani externus diabetes mellitus 34 mannen / 46 vrouwen

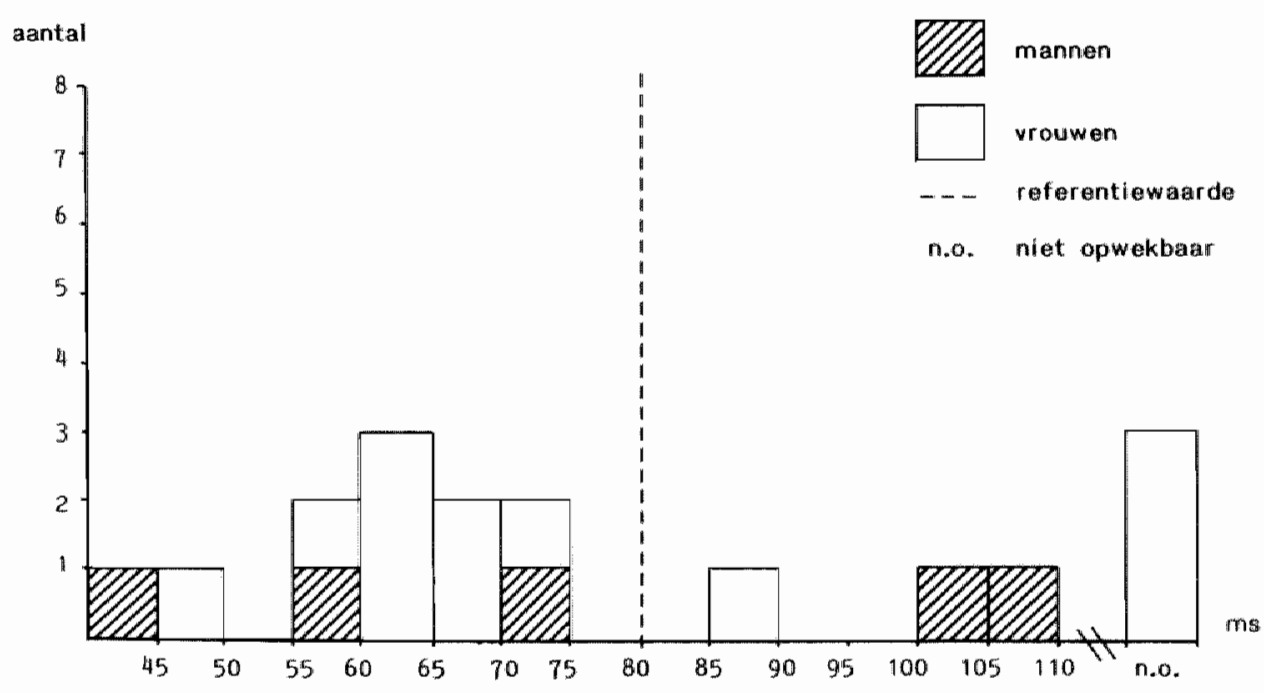

Figuur 6.4

Latentietijden VESICO-ANALE-REFLEX $\mathrm{m}$. bulbocavernosus diabetes mellitus 5 mannen / 12 vrouwen 
VAR M. SPHINCTER ANI EXTERNUS BIJ PROEFPERSOON

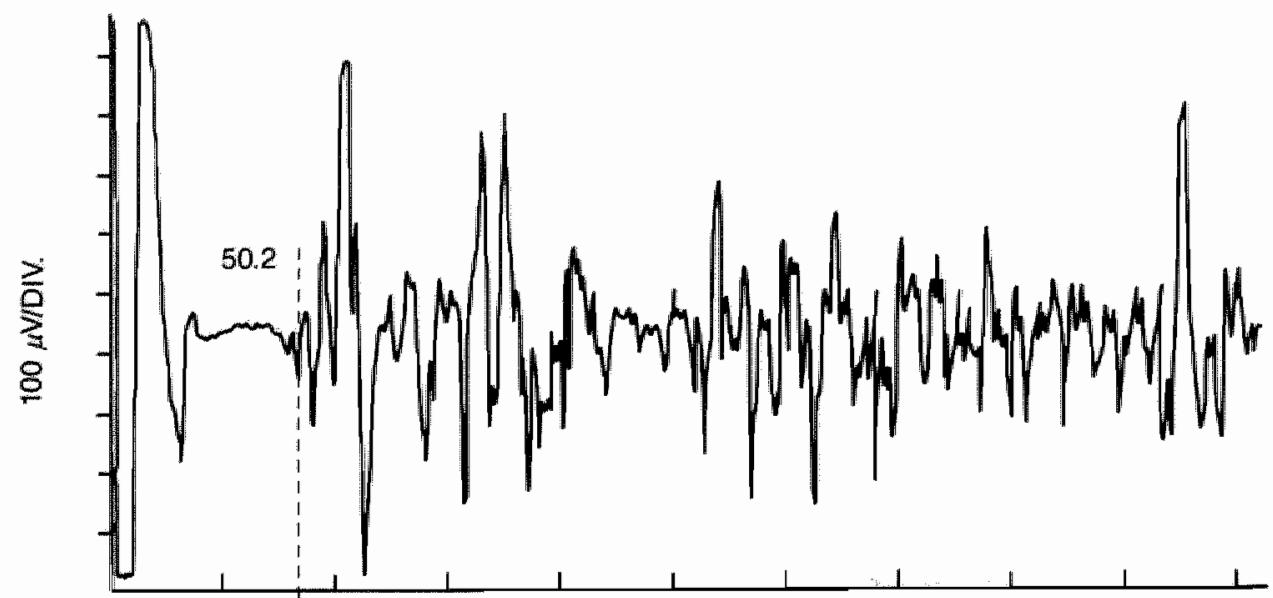

30 MSIDIV

Figuur 6.5

Latentietijd $50,2 \mathrm{~ms}$ Amplitudo $880 \mu \mathrm{V}$

LF $30 \mathrm{~Hz} \quad \mathrm{HF} 3000 \mathrm{~Hz}$

VAR. M. BULBOCAVERNOSUS BIJ PROEFPERSOON

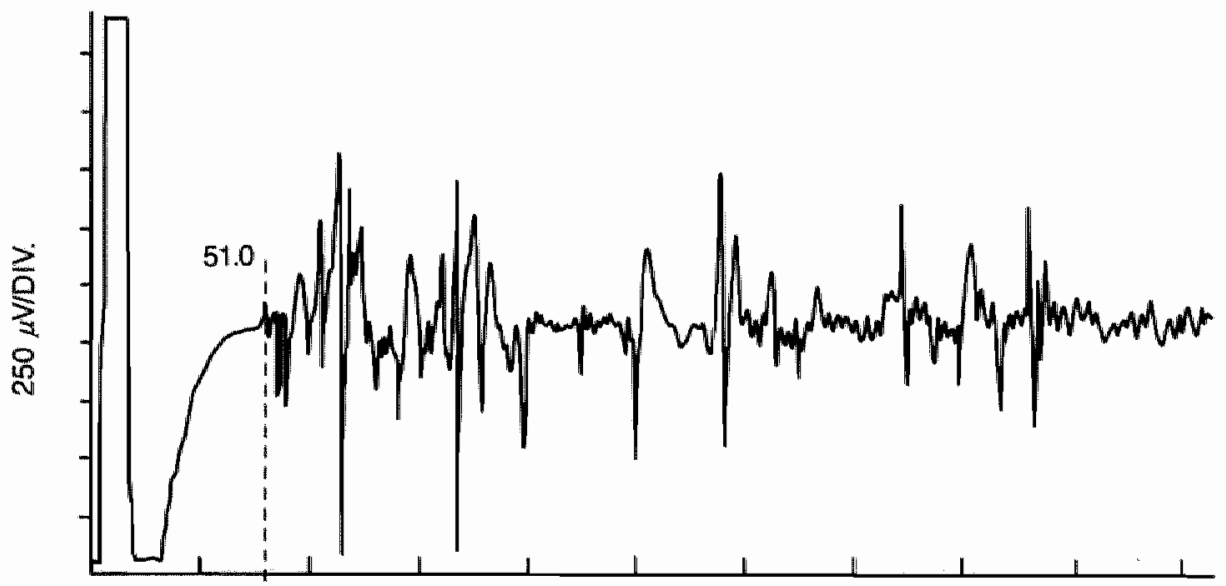

$30 \mathrm{MS} / \mathrm{DIV}$

Figuur 6.6

Latentietijd $51,0 \mathrm{~ms}$ Amplitudo $1500 \mu \mathrm{V}$

LF $30 \mathrm{~Hz} \quad \mathrm{HF} 3000 \mathrm{~Hz}$ 
VAR. M. SPHINCTER ANI EXTERNUS BIJ PATIENT MET DIABETES MELLTUS

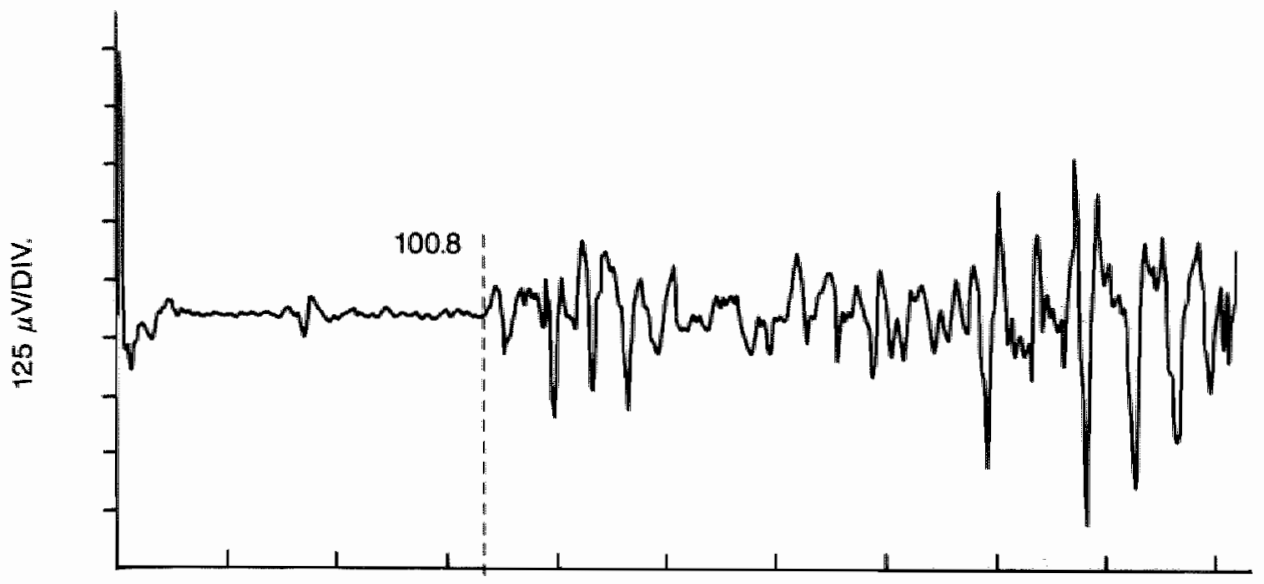

30 MSIDIV.

\section{Figuur 6.7}

Latentietijd 100,8 ms Amplitudo $280 \mu \mathrm{V}$

LF $30 \mathrm{~Hz} \quad \mathrm{HF} 3000 \mathrm{~Hz}$

VAR M. BULBOCAVERNOSUS BIJ PATIENT MET DIABETES MELLITUS

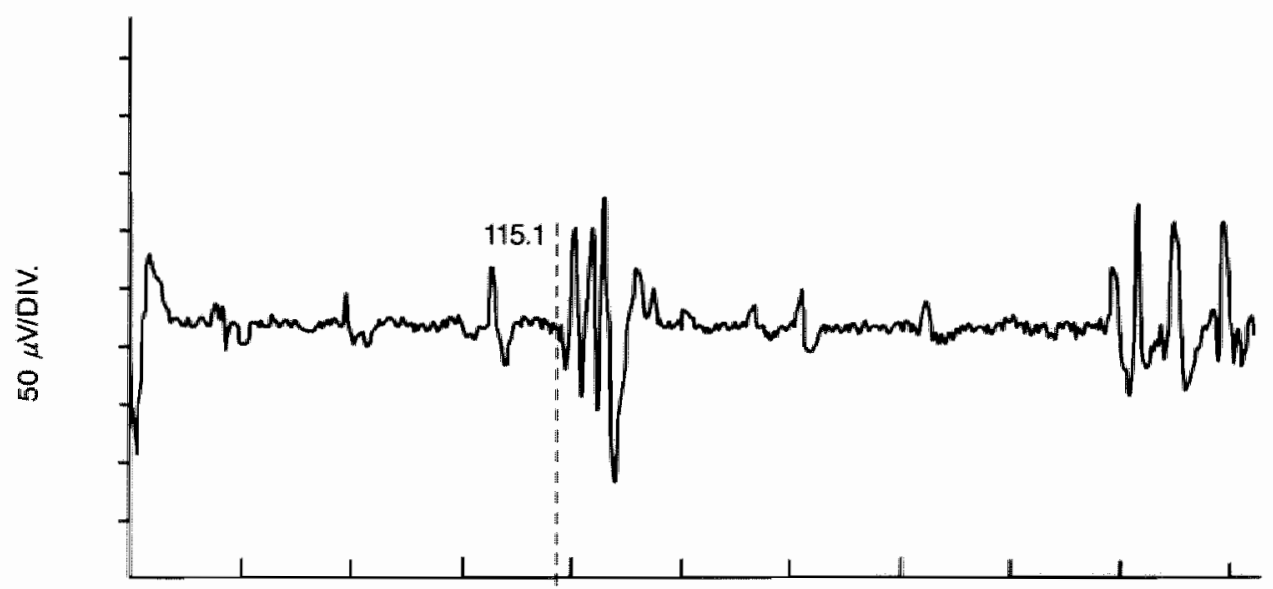

30 MSIDIV. 


\subsubsection{DISCUSSIE}

De waarden voor de VAR in onze referentilegroep kwamen goed overeen met de normaalwaarden in de literatuur (zile 4.1.2.4.).

Bradley (1972) vermeldde dat bij relaxatie van het perineum de respons verdween. Wanneer dat niet gebeurde beschouwde hij dat als een teken van een laesie van de supraspinale innervatie van de nucleus pudendus via de tractus corticospinalis. Evenals Yalla (1978) en Vereecken et al. (1981) slaagden ook wij slechts bil een minderheid van de proefpersonen (5) erin de respons te laten verdwijnen.

Andersen en Bradley (1976) onderzochten bij 27 patienten met diabetes mellitus de VAR. Bij 7 patienten was geen antwoord opwekbaar en bij de overige 20 vonden zij een spreiding van de latentietijden van 60 tot $120 \mathrm{~ms}$. Wij vonden een variatie van 50 tot $118 \mathrm{~ms}$ en konden bij 3 van de 80 patienten geen VAR bij registratie uit de $\mathrm{m}$. sphincter ani externus en $m$. bulbocavernosus verkrijgen.

Overeenkomstig de literatuur (Andersen en Bradley, 1976) vonden ook wij dat de duur van de respons vaak korter was en de amplitudo verlaagd bij een verlengde latentietijd. Welke de mogelijke betekenis is van bovenstaande bevindingen in het kader van urogenitale stoornissen bij de diabetici wordt besproken in hoofdstuk 7.

\subsubsection{ONDERZOEK VAN DE BULBOCAVERNOSUSREFLEX I EN $\|$ (BCR I EN \|I)}

\subsubsection{METHODE}

De $\mathrm{n}$. dorsalis penis of $\mathbf{n}$. clitoridis werd met oppervlakte-elektroden gestimuleerd (kathode ongeveer $2 \mathrm{~cm}$ proximaal van de anode).

Voor registratie van de BCR I zowel in de $\mathrm{m}$. sphincter ani externus als $\mathrm{m}$. bulbocavernosus werd bij proefpersonen gebruik gemaakt van ongeveer 10 elektrische stimuli met wisselende intervallen van meerdere seconden gegeven. De eerste en tweede component van de $B C R$ werden met maximale amplitudo verkregen bil een prikkelduur van 0,1 of 0,2 ms en een prikkelsterkte van 100 tot $300 \mathrm{~V}$. De stimulus intensiteit nodig om de BCR III te registreren was erg wisselend en was lager, gelijk of in de meeste gevallen hoger dan voor de eerste respons.

Gestimulleerd werd met toenemende spanning en duur tot een maximale amplitudo werd verkregen. Dit was meestal beneden de pijndrempel en ongeveer 2,5 maal de gevoelsdrempel.

Alleen responsen na supramaximale stimulatie en responsen die tenminste drie maal reproduceerbaar waren werden geaccepteerd.

Bij patienten met diabetes mellitus was in het algemeen een langere duur van de stimulus tot soms $1 \mathrm{~ms}$ nodig en een hogere prikkelsterkte om een maximale respons te verkrijgen. Soms waren bij patienten met diabetes mellitus korte stimulustreintjes nodig om een maximale respons te verkrijgen.

De afleiding van het reflexantwoord en de registratie van de reflex vonden op dezelfde wijze plaats als bij de VAR.

\subsubsection{RESULTATEN}

De voornaamste onderzoekresultaten worden getoond in tabel 6.4 en figuren $6.9 \mathrm{t} / \mathrm{m} 6.20$ 
Latentietijden BCR I en II (m. sphincter ani externus en m. bulbocavernosus) bij de referentie- en patienten-groep

- BCR I m, sphincter ani externus

Totaal

Niet opwekbaar

Spreiding latentietijden

Gemiddelde waarde

biij mannen en vrouwen mannen

vrouwen

Afwezige of vertraagde

$\mathrm{BCR} \mid(>$ gemiddelde $+2 \mathrm{SD})$

- BCA II m. sphincter ani externus

Totaal

Niet opwekbaar

Spreiding latentietijden

Gemiddelde waarde

bij mannen en vrouwen

mannen

vrouwen

Afwezige of vertraagde

BCA $\|$ (> gemiddelde +2SD)

- BCR I m. bulbocavernosus

Totaal

Niet opwekbaar

Spreiding latentietijden

Gemiddelde waarde

bij mannen en vrouwen mannen

vrouwen

Afwezige of vertraagde

BCR I (> gemiddelde +2SD)

- BCR // m. bulbocavernosus

Totaal

Niet opwekbaar

Spreiding latentietijden

Gemiddelde waarde

bij mannen en vrouwen

mannen

vrouwen

Afwezige of vertraagde

BCR $\|(>$ gemiddelde $+2 S D)$

Referentiegroep Patientengroep

$\begin{array}{ll}\mathrm{N} & 86 \\ \mathrm{~N} & * \\ & 20-40 \mathrm{~ms} \\ & 31,3 \mathrm{~ms} \\ & \text { (SD } 4,9 \mathrm{~ms}) \\ \mathrm{N} & 50 \\ & 31,7 \mathrm{~ms} \\ & (\mathrm{SD} 4,8 \mathrm{~ms}) \\ \mathrm{N} & 36 \quad \mathrm{~ms} \\ & 30,8 \mathrm{~ms}) \\ & \text { (SD } 5,2 \mathrm{~ms}) \\ \mathrm{N} & \end{array}$

80

1

$21-79 \mathrm{~ms}$

$38,4 \mathrm{~ms}$ **

(SD $10,3 \mathrm{~ms}$ )

33

$37,2 \mathrm{~ms}$ *

(SD $6,9 \mathrm{~ms}$ )

46

39,2 ms **

(SD $12,2 \mathrm{~ms}$ )

$23(29 \%)$

80

3

49-137 ms

$78,6 \mathrm{~ms}$ *

(SD 14,9 ms)

32

N 49

(SD $10,4 \mathrm{~ms}$ )

$74,1 \mathrm{~ms}$

(SD $10,2 \mathrm{~ms}$ )

N 36

$67,4 \mathrm{~ms}$

N

(SD $9,6 \mathrm{~ms}$ )

$77,4 \mathrm{~ms}$

(SD 10,3 ms)

45

$79,5 \mathrm{~ms}$ *

(SD $17,4 \mathrm{~ms}$ )

$13(16 \%)$

$\begin{array}{lll}\mathbf{N} & 21 & 18 \\ \mathbf{N} & 1 & 1\end{array}$

26-44 ms

$32,8 \mathrm{~ms}$

(SD $4,4 \mathrm{~ms}$ )

N 11

$30,9 \mathrm{~ms}$

(SD 2,4 ms)

N 9

$35,1 \mathrm{~ms}$

N

(SD $5,3 \mathrm{~ms}$ )

31-69 ms

$41,9 \mathrm{~ms}$ *

(SD 9,9 ms)

6

$40,3 \mathrm{~ms}$

(SD 14,2 ms)

11

$42,7 \mathrm{~ms}$ *

(SD 17,3 ms)

$7(39 \%)$

15

N 21

N 1

62-96 ms

$79,1 \mathrm{~ms}$

(SD $9,2 \mathrm{~ms}$ )

N 11

$79,5 \mathrm{~ms}$

(SD $10,6 \mathrm{~ms}$ )

$N$

9

$78,8 \mathrm{~ms}$

(SD $7,8 \mathrm{~ms}$ )

N

1

61-142 ms

$85,9 \mathrm{~ms}$

(SD 25,3 ms)

4

$89,0 \mathrm{~ms}$

(SD $23,7 \mathrm{~ms}$ )

10

$84,6 \mathrm{~ms}$

(SD 27,2 mis)

$4(27 \%)$

${ }^{*} \mathbb{P}<0,05$

**P<0,001 


\section{aantal}

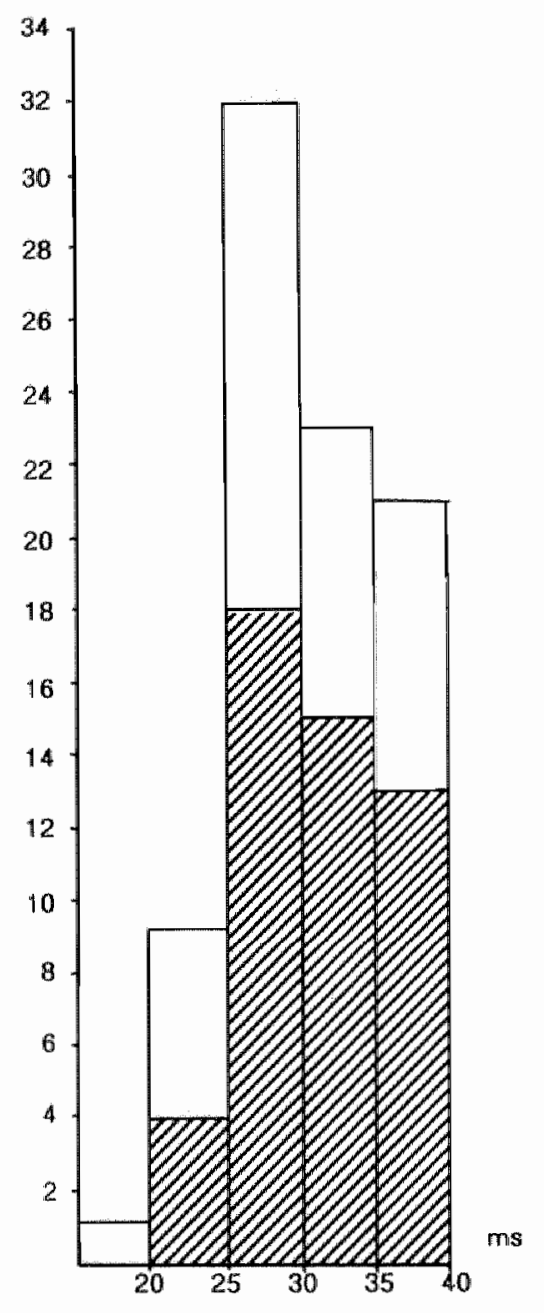

aantal

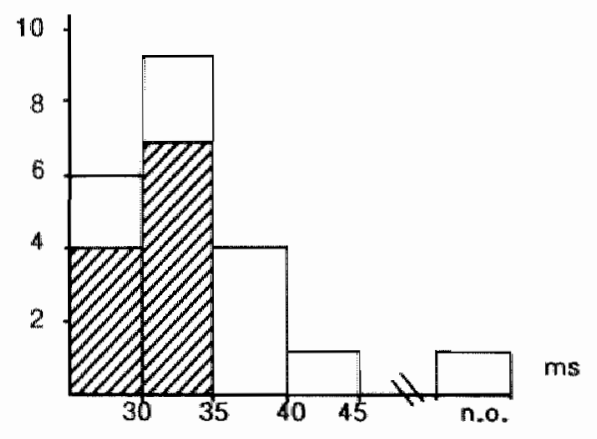

Figuur 6.9

Latentietijden BULBOCAVERNOSUSREFLEX ।

$\mathrm{m}$. sphincter ani externus

referentiegroep 50 mannen / 36 vrouwen
Figuur 6.10

Latentietijden BULBOCARVERNOSUSREFLEX ।

$\mathrm{m}$. bulbocavernosus

referentiegroep 11 mannen / 10 vrouwen 


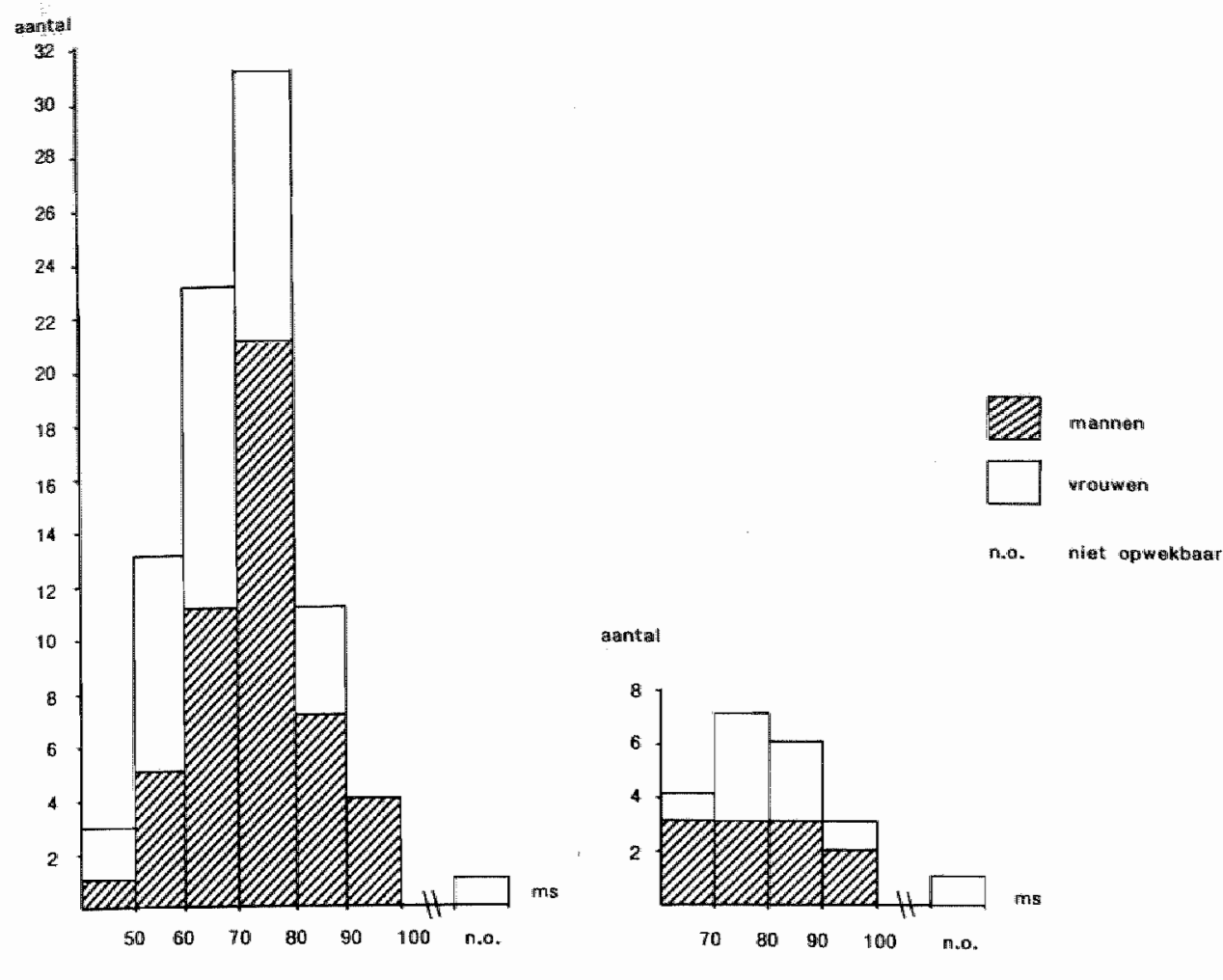

Figuur 6.11

Figuur 6.12

Latentietijden BULBOCAVERNOSUS-

REFLEX II

m. sphincter ani externus

referentiegroep 50 mannen / 36 vrouwen

Latentietijden BULBOCAVERNOSUS-

\section{REFLEX II}

m. bulbocavernosus

referentiegroep 11 mannen / 10 vrouwen

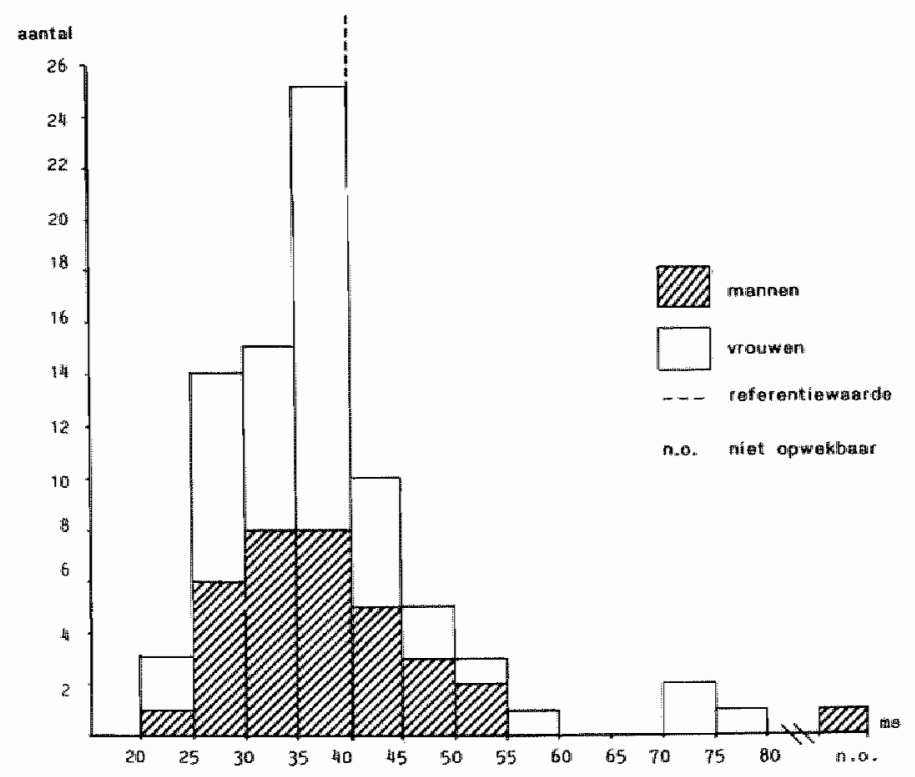

Figuur 6.13

Latentietijden BULBOCAVERNOSUSREFLEX I m. sphincter ani externus diabetes mellitus 34 mannen / 46 vrouwen 


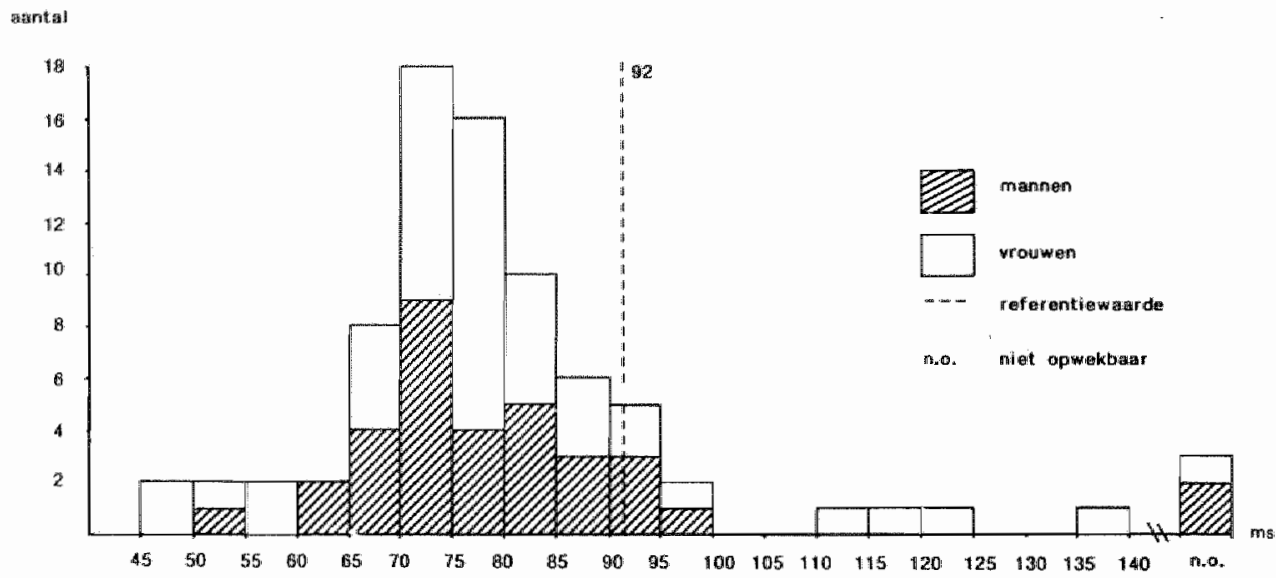

Figurur 6.14

Latentietijden BULBOCAVERNOSUSREFLEX II $\mathrm{m}$. sphincter ani externus diabetes mellitus 34 mannen / 46 wrouwen

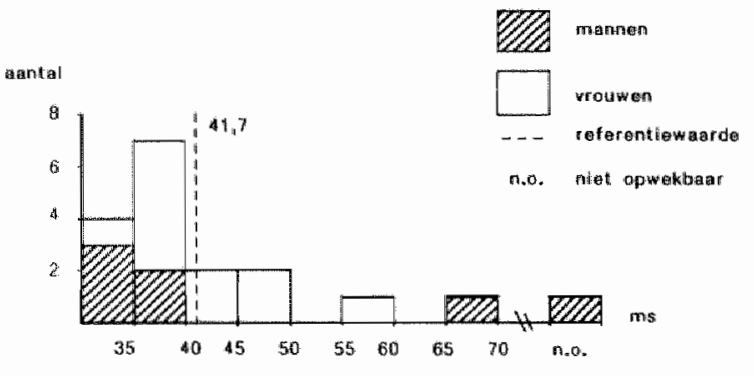

Figuur 6.15

Latentietijdens BULBOCAVERNOSUSREFLEX I m. bulbocavernosus diabetes mellitus 7 mannen / 11 vrouwen 


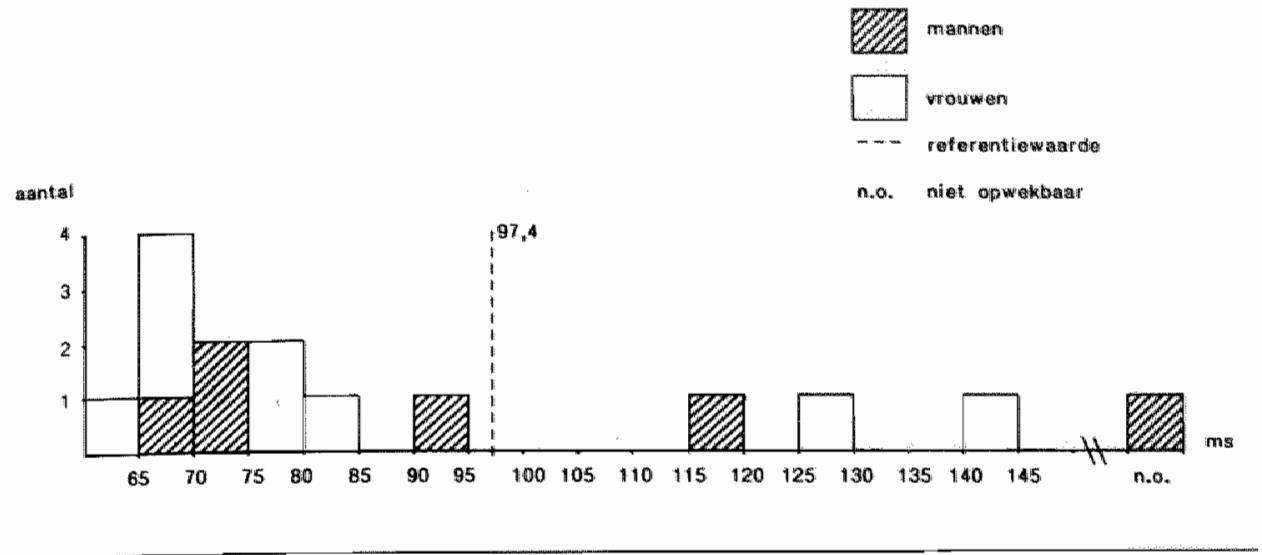

Figuur 6.16

Latentietijden BULBOCAVERNOSUSREFLEX \|| m. bulbocavernosus diabetes mellitus 5 mannen / 10 vrouwen 
BCR M. SPHINCTER ANI EXTERNUS BIJ PROEFPERSOON

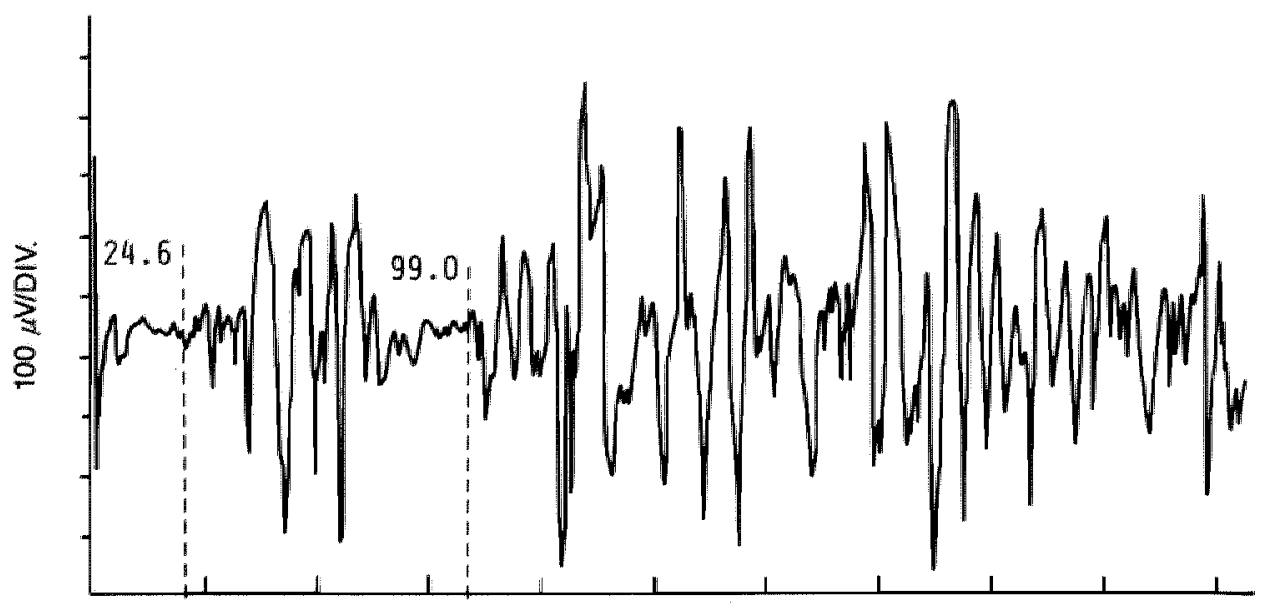

VIONZM OE

Figurur 6.17

Latentietijd $R_{1} 24,6 \mathrm{~ms} R_{2} 99,0 \mathrm{~ms}$

Amplitudo $\mathrm{R}_{1} 520 \mu \mathrm{V} \quad \mathrm{R}_{2} 750 \mu \mathrm{V}$

LF $30 \mathrm{~Hz}$

HF $3000 \mathrm{~Hz}$

BCR M. BULBOCAVERNOSUS BIJ PROEFPERSOON

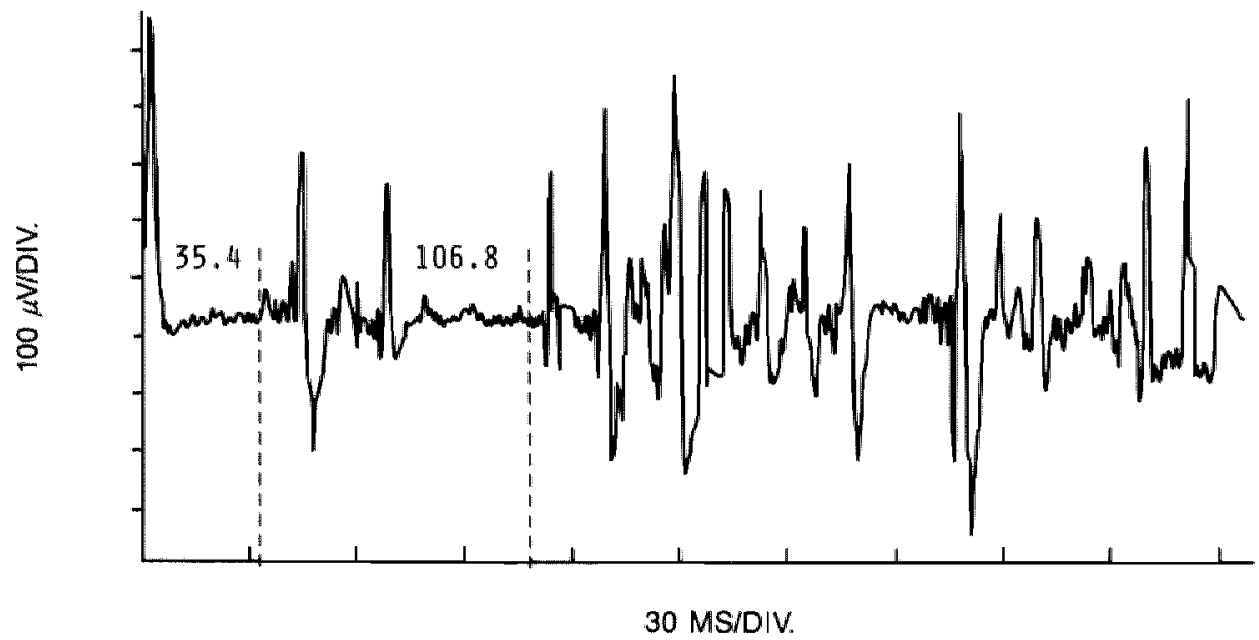

Figuur 6.18

Latentietijd $R_{1} 35,4$ ms $R_{2} \quad 106,8 \mathrm{~ms}$

LF $30 \mathrm{~Hz}$

Amplitudo $R_{1} 490 \mu \mathrm{V} \quad R_{2} 640 \mu \mathrm{V}$

$\mathrm{HF} 3000 \mathrm{~Hz}$ 
BCR M. SPHINCTER ANI EXTERNUS BIJ PATIENT MET DIABETES MELLITUS

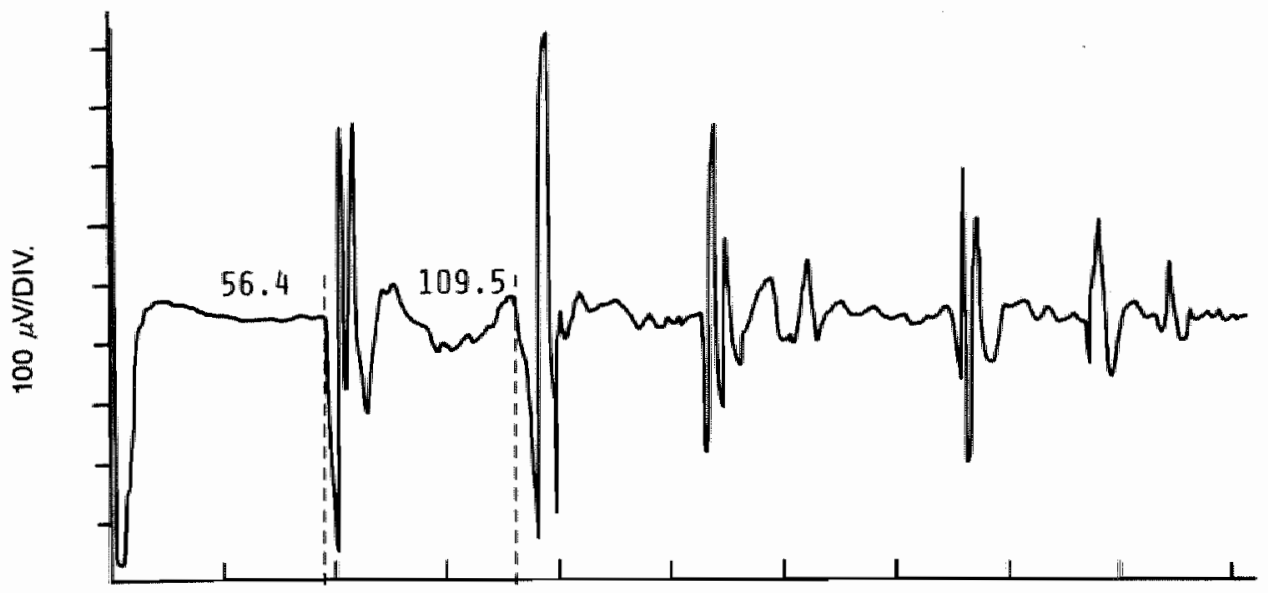

$30 \mathrm{MSIDIV}$.

Figur 6.19

Latentietijd $R_{1} 56,4 \mathrm{~ms} R_{2} 109,5 \mathrm{~ms}$

LF $30 \mathrm{~Hz}$

Amplitudo $R_{1} 710 \mu \mathrm{V} \quad R_{2} 800 \mu \mathrm{V}$

HF $3000 \mathrm{~Hz}$

BCA M. BULBOCAVERNOSUS BIJ PATIENT MET DIABETES MELLITUS

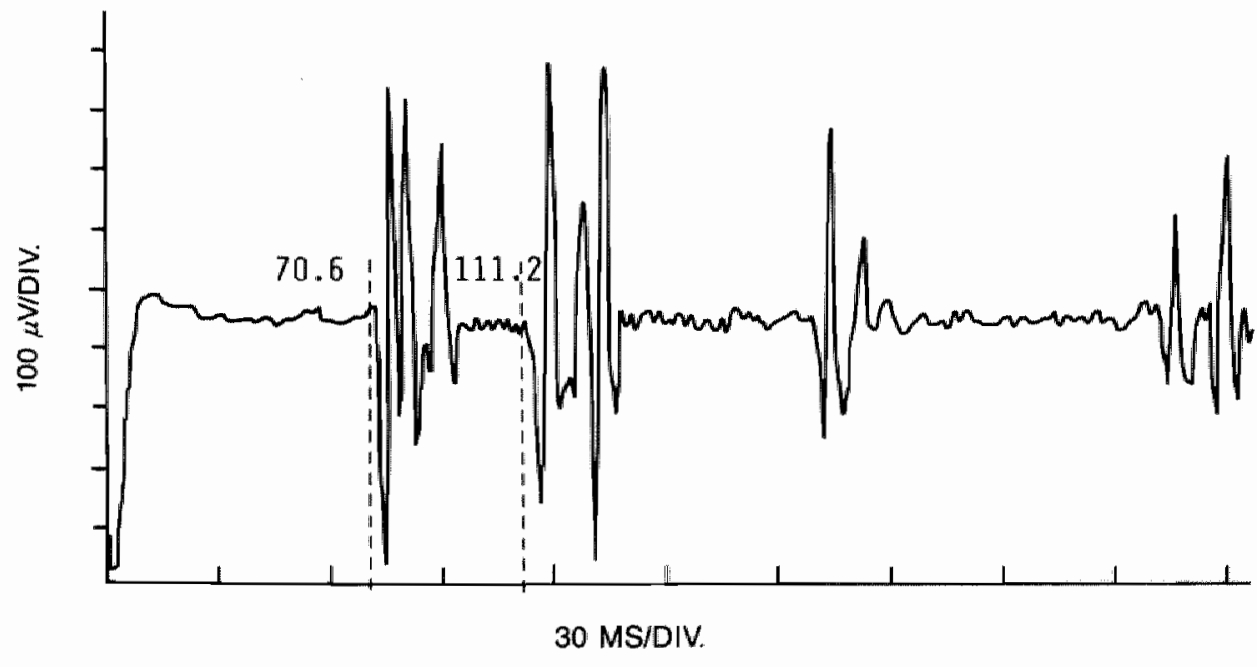


De gemiddelde latentietijd van de BCR II $\mathrm{m}$. sphincter ani externus was in de referentiegroep bil de mannen significant langer dar bij de wrouwen ( $P<0,05$ ).

De gemiddelde latentietijd van de BCR | $\mathrm{m}$. bulbocavernosus was in de referentiegroep bij de vrouwen significant langer dan bij de mannen ( $P<0,05$ ).

De gemiddelde latentietijd van de BCR I bij de referentiegroep geregistreerd uit de $m$. sphincter ani externus en de $\mathrm{m}$. bulbocavernosus verschilde niet wezenlijk (zie tabel 6.4). De duur van de BCR I uil beide spieren varieerde van ca. 10 tot ca. $50 \mathrm{~ms}$. De amplitudo varieerde van ca. 150 tot ca. $750 \mathrm{uV}$. De duur van de BCR II varieerde van ca. 40 tot ca. $300 \mathrm{~ms}$ en had een amplitudo die varieerde van ca. 150 tot ca. $900 \mathrm{uV}$.

Bij toename van de intensiteit en duur van de stimulus nam de latentietijd af en namen de duur en amplitudo toe.

Bij zeer hoge intensiteit liepen beide responsen in elkaar over en waren niet meer van elkaar te onderscheiden.

Bij de patienten met een verlengde latentietijd was de duur van zowel de eerste als tweede respons meestal korter en minder polyfasisch dan bij de referentiegroep. De amplitudo van de respons was bij de patienten- en referentiegroep nagenoeg identiek.

De latentietijd van de BCR I was nauwelijks afhankelijk van de leeftijd van de onderzochte.

De BCR I en BCR II uit de $\mathrm{m}$. sphincter ani externus en de $\mathrm{m}$. bulbocavernosus konden niet onderdrukt worden door relaxatie.

\subsubsection{DISCUSSIE}

De latentietijden van de BCR I en BCR III in onze referentiegroep kwamen goed overeen met de normaalwaarden in de literatuur (zie 4.1.3.4.).

In de ons beschikbare literatuur werden geen vergelijkbare gegevens verkregen over de $B C R$ II na stimulatie van de $m$. dorsalis penis of $n$. clitoridis en bij registratie, hetzij uit de $\mathrm{m}$. sphincter ani externus hetzij uit de m. bulbocavernosus.

Alleen Vodusek et al. (1983) beschreven een tweede respons in de $\mathrm{m}$. bulbocavernosus doch zij stimuleerden peri-anaal en vonden een gemiddelde van 53,2 ms met een spreiding van 50-60 ms. Wij vonden een gemiddelde latentietijd van de BCR II na stimulatie van de $\mathrm{n}$. dorsalis penis of $\mathrm{n}$. clitoridis, en bij registratie uit de $\mathrm{m}$. sphincter ani externus bij 85 proefpersonen, van $71,2 \mathrm{~ms}$ (SD $10,4 \mathrm{~ms}$ ). In tegenstelling tot het onderzoek van Vodusek et al. (1983) toonde de tweede respons bij ons onderzoek geen uitdoving door gewenning.

Geen vergelijkbare gegevens konden worden verkregen over de BCR I en BCR II bij registratie uit de $\mathrm{m}$. sphincter ani externus bij diabetici.

Welke de mogelijke betekenis is van onze bovenstaande bevindingen in het kader van urogenitale stoornissen bij diabetici wordt besproken in hoofdstuk 7 .

\subsubsection{ONDERZOEK VAN DE TIBIALIS/PLIDENDUS/PELVICUS EVOKED POTENTIALS (RESP. TEP/PEP/PHEP)}

\subsubsection{METHODE}

\section{STIMULATIE N. TIBIALIS}

De n. tibialis werd gestimulleerd achter de mediale malleolus met een bipolaire oppervlakte-elektrode waarvan de met vilt beklede polen een vaste onderlinge afstand hebben van ca. $2 \mathrm{~cm}$. Gebruikt werden rechthoekpulsen van $0,2 \mathrm{~ms}$ duur, 100 tot $200 \mathrm{~V}$ (beneden de pijndrempel) en met een frequentie van $1 \mathrm{~Hz}$. De intensiteit van de stimulus werd opgevoerd tot het moment dat kleine bewegingen van de tenen optraden (over het algemeen bij ongeveer 1,5 maal de gevoelsdrempel). Toegediend werden 100 at 200 
stimuli, soms ook minder, tot een volledig specifiek complex van de SSEP werd verkregen.

\section{STIMULATIE N. DORSALIS PENIS OF N. CLITORIDIS}

De $\mathrm{n}$. dorsalis penis werd met de eerder beschreven bipolaire oppervlakte-elektrode gestimuleerd ter plaatse van het proximale deel van de dorsale zijde van de penis (kathode proximaal).

De $n$. clitoridis werd gestimuleerd tussen de labia minora met dezelfde oppervlakteelektroden. De proximale elektrode (kathode) werd tegen de clitoris geplaatst. Het aantal toegediende prikkels, duur en intensiteit waren hetzelfde als bil stimulatie van de $n$. $t i-$ bialis.

Bij stimulatie van de $n$. dorsalis penis en de n. clitoridis werd de intensiteit van de stimulus opgevoerd tot ongeveer 1,5 maal de gevoelsdrempel $(80-150 \mathrm{~V})$ tenzij het onderzoek als té onaangenaam werd ervaren. Toegediend werden 100 a 200 stimuli tot een volledig specifiek complex van de SSEP werd verkregen.

\section{STIMULATIE N. PELVICUS}

De $n$. pelvicus werd gestimuleerd met elektrische rechthoekprikkels ter plaatse van het proximale deel van de urethra via dezelfde Foley sillicone katheter als bij de VAR (zie 6.1.2.1.).

De intensiteit van de stimulus werd opgevoerd tot ongeveer 2,5 maal de gevoelsdrempel, tenzij het onderzoek als pijnlijk werd ervaren.

Toegediend werden 200 á 300 stimuli tot een volledig specifiek complex van de SSEP werd verkiregen.

Het benodigde aantal stimuli was in het algemeen 2 maal zo groot als bij stimulatie van de $n$. tibialis en $n$. pudendus of $n$. clitoridis, en met een duur van $0,5 \mathrm{~ms}$.

\section{AFLEIDING VAN DE CORTICALE EVOKED POTENTIAL}

De elektrodeplaatsing was dezelfde bij registratie van de SSEP van de $n$. tibialis, $n$. pudendus en de $n$. pelvicus (n. hypogastricus).

De aktieve elektrode werd aangebracht in de mediaanlijn $2 \mathrm{~cm}$ achter $\mathrm{Cz}$ ( $\mathrm{Cz}$, internationaal 10-20 systeem), de referentie-elektrode ter plaatse van $\mathrm{Fz}$ en de aardelektrode ter plaatse van $\mathrm{Pz}$.

Voor de stimulatie en voor de registratie van de verschillende SSEP's werd van dezelfde apparatuur gebruik gemaakt als bij de VAR en BCR.

De bandbreedte van de versterker bij registratie van het wroege complex van alle corticaal geregistreerde evoked potentials lag tussen 3,2 en $1600 \mathrm{~Hz}$. De analysetijd van de averager was $250 \mathrm{~ms}$, waarin opgenomen een pre-stimulus interval van $100 \mathrm{~ms}$. De gevoeligheid van de versterker was ook bij alle voornoemde corticaal geregistreerde potentialen

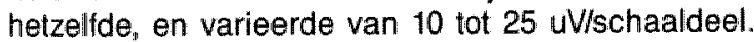

Alle geregistreerde evoked potentialls werden uitgemiddeld. De latentietijden konden direct van het scherm van de oscilloscoop worden afgelezen.

Via een elektronische marker werd bij alle door ons onderzochte evoked potentials de latentietijd geregistreerd. Wij bepaalden steeds de latentietijd tot de eerste positieve top, daar deze het meest constant aanwezig was.

\subsubsection{RESULTATEN}

De voornaamste onderzoekresultaten worden getoond in tabel 6.5 en figuren 6.21 $\mathrm{t} / \mathrm{m} 6.32$. 
$P_{1}$ - latentietijden van TEP, PEP en PHEP bij de referentie- en patientengroep

TEP

Totaal

Niet opwekbaar

Spreiding latentietijden

Gemiddelde waarde

bij] mannen en vrouwen mannen

vrouwen

Vertraagde TEP

$(>$ gemiddelde $+2 S D)$

PEP

Totaal

Niet opwekbaar

Spreiding latentietijden

Gemiddelde waarde

bij mannen en vrouwen mannen

vrouwen

Afwezige of vertraagde

PEP ( $>$ gemiddelde +2SD)

\section{PHEP}

Totaal

Niet opwekbaar

Spreiding latentietijden

Gemiddelde waarde

bij mannen en vrouwen

mannen

vrouwen

Afwezige of vertraagde

PHEP (> gemiddelde +2SD)
Referentie-

groep

N 26

N

37-46 ms

$41,2 \mathrm{~ms}$

(SD 2,5 ms)

N 16

42,4 mis

(SD 2,2 ms)

N 10

$39,1 \mathrm{~ms}$

(SD 1,1 ms)

N

N 86

$N$ -

$34-47 \mathrm{~ms}$

$41,2 \mathrm{~ms}$

(SD 3,2 ms)

N 50

$42,5 \mathrm{~ms}$

(SD 3,0 ms)

$\mathrm{N} \quad 36$

$39,4 \mathrm{~ms}$

N

(SD 2,6 ms)

N 47

N 2

53-84 ms

$66,3 \mathrm{~ms}$

(SD $7,1 \mathrm{~ms}$ )

N 23

$67,8 \mathrm{~ms}$

(SD 7,9 ms)

N

22

$64,8 \mathrm{~ms}$

(SD 6,3 ms)
Patienten-

groep

64

$37-74 \mathrm{~ms}$

$49,6 \mathrm{~ms}^{\text {** }}$

(SD $7,7 \mathrm{~ms}$ )

23

$49,6 \mathrm{~ms}^{*}$

(SD $7,8 \mathrm{~ms}$ )

41

$49,5 \mathrm{~ms}$ **

(SD $7,7 \mathrm{~ms}$ )

$44(69 \%)$

80

1

$32-66 \mathrm{~ms}$

$44,0 \mathrm{~ms}$ *

(SD $5,9 \mathrm{~ms}$ )

33

$45,3 \mathrm{~ms}$ *

(SD 4,0 ms)

46

$43,1 \mathrm{~ms}$ *

(SD 6,9 ms)

$18(22 \%)$

N

40

1

45-145 ms

$71,9 \mathrm{~ms}$

(SD 20,1 ms)

19

$66,9 \mathrm{~ms}$

(SD 14,2 ms)

20

$76,7 \mathrm{~ms}$ *

(SD 23,8 ms)

$10(25 \%)$

- $\mathbb{P}<0,05$

* $P<0,001$ 
De gemiddelde P1 latentietijd van de PEP en de TEP was in de referentiegroep bij de mannen significant langer dan bij de vrouwen ( $P<0,001)$.

De amplitudio van de corticale TEP was meestal $2 \times z 0$ groot als die van de PEP en de amplitudo van de corticale PEP was vaak $2 \times$ zo groot als die van de PHEP.
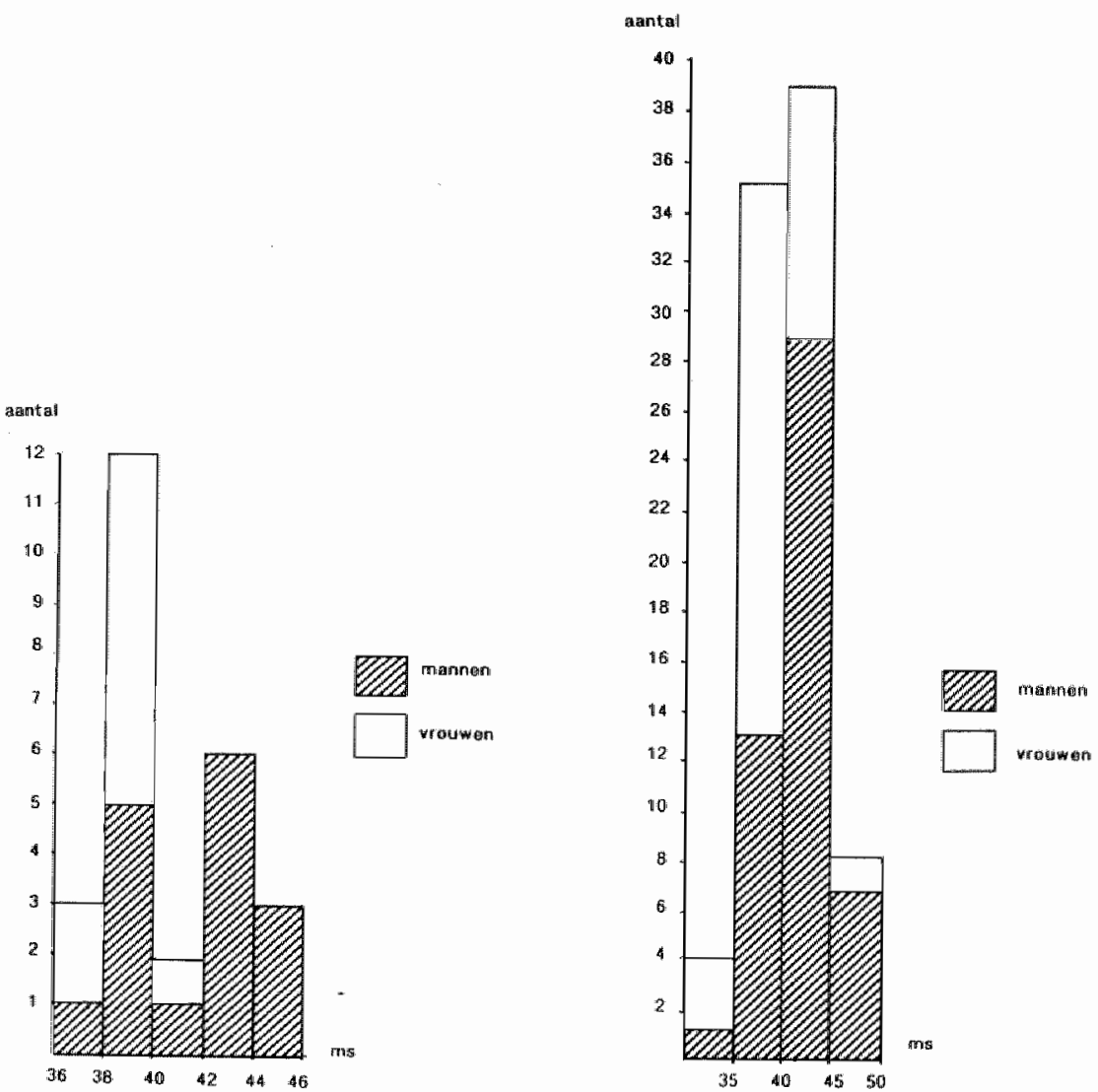

Figuur 6.21

$P_{1}$ - latentietijden TIBIALIS EVOKED POTENTIAL

referentiegroep 16 mannen $/ 10$ vrouwen
Figuur 6.22

$P_{1}$ - latentietijden PUDENDUS EVOKED POTENTIAL

referentiegroep 50 mannen / 36 vrouwen 


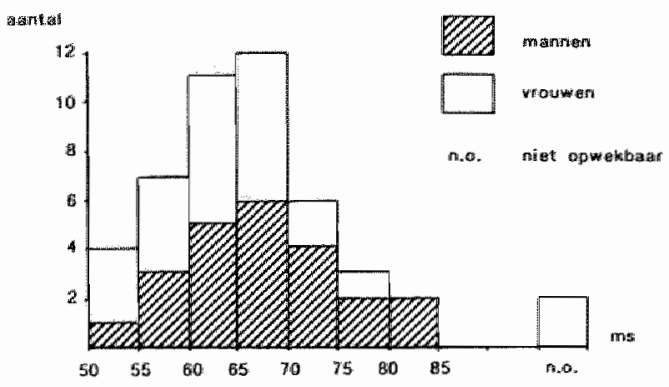

\section{Figuur 6.23}

$P_{1}$ - latentietijden PELVICUS (HYPOGASTRICUS) EVOKED POTENTIAL referentiegroep 23 mannen / 24 vrouwen

TIBIALIS EVOKED POTENTIAL BIJ PROEFPERSOON

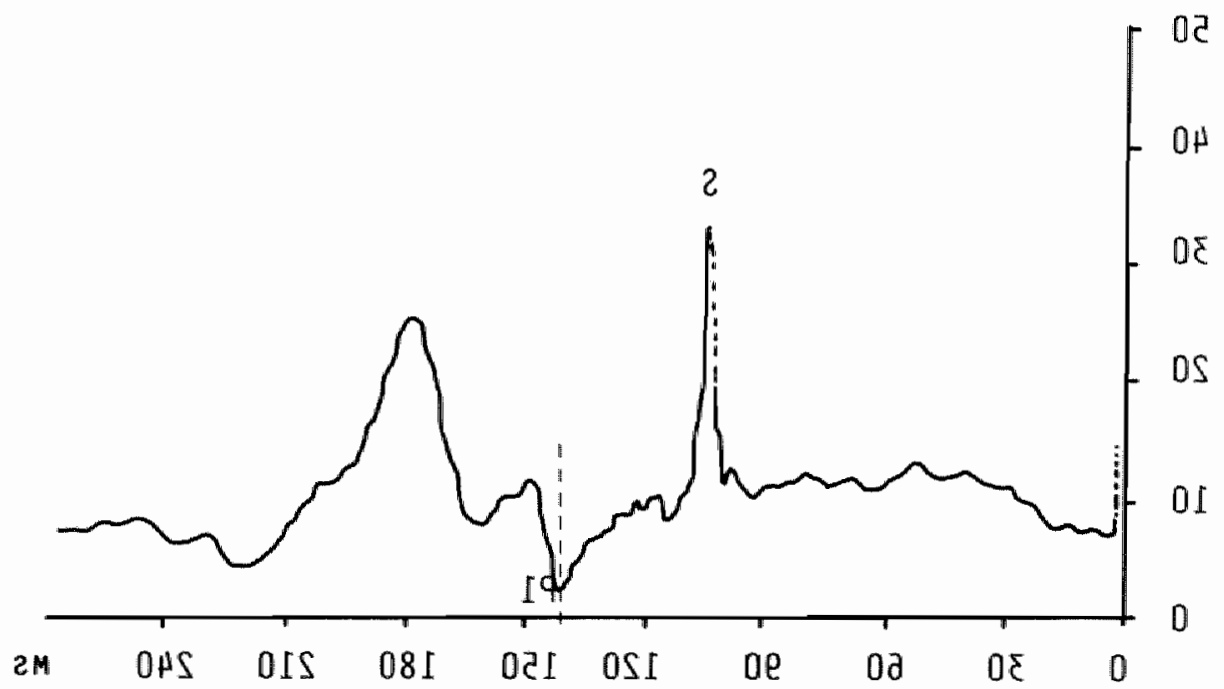

Figuur 6.24

$\mathrm{S}$ Stimulatie artefact (bij $100 \mathrm{~ms}$ )

$P_{1} 40 \mathrm{~ms}$

LF $3 \mathrm{~Hz}$

HF $1600 \mathrm{~Hz}$

$\begin{array}{lc}\text { pre-stimulusinterval } & 100 \mathrm{~ms} \\ \text { aantal stimuli } & 100 \\ \text { prikkelduur } & 0,2 \mathrm{~ms} \\ \text { prikkelsterkte } & 100 \mathrm{~V} \\ \text { frequentie } & 1 \mathrm{~Hz}\end{array}$




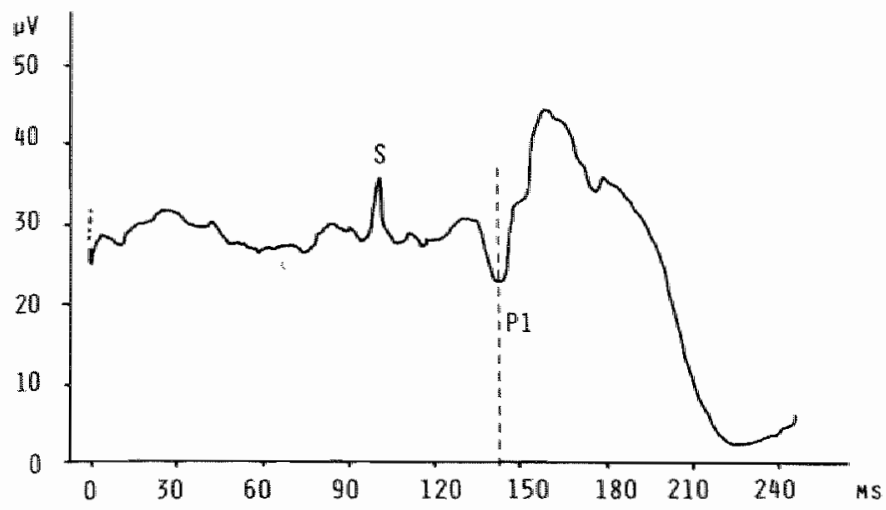

\section{Figuur 6.25}

$\mathrm{S}$ Stimulatie artefact (bij $100 \mathrm{~ms}$ )

$P_{1} 42,6 \mathrm{~ms}$

LF $8 \mathrm{~Hz}$

$\mathrm{HF} 1600 \mathrm{~Hz}$

$\begin{array}{ll}\text { pre-stimulusinterval } & 100 \mathrm{~ms} \\ \text { aantal stimuli } & 100 \\ \text { prikkelduur } & 0,2 \mathrm{~ms} \\ \text { prikkelsterkte } & 100 \mathrm{~V} \\ \text { frequentie } & 1 \mathrm{~Hz}\end{array}$

$4 \mathrm{~V} \quad$ PUDENDUS EVOKED POTENTIAL BIJ PROEFPERSOON

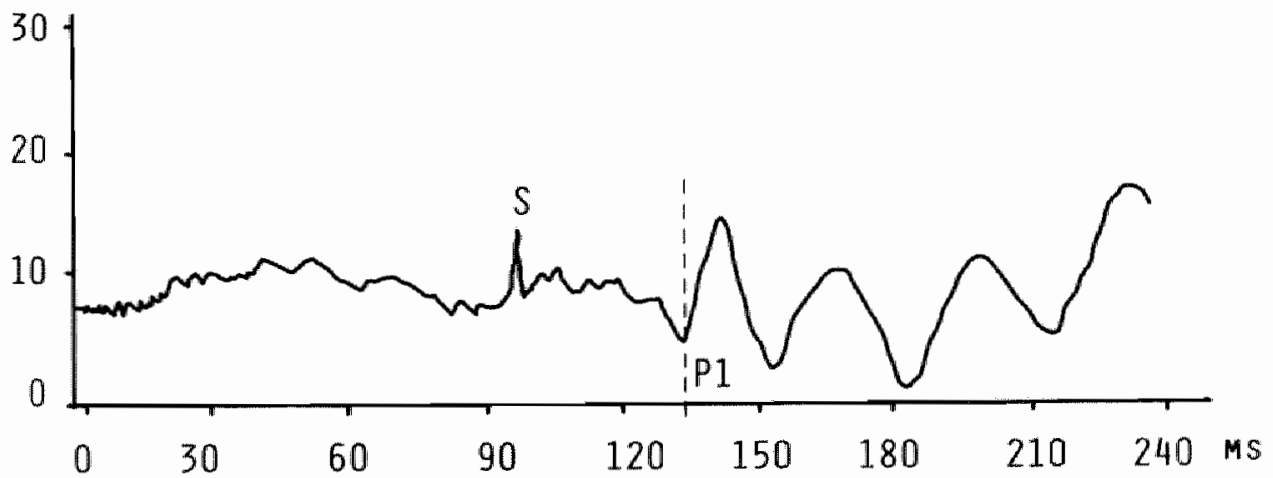

Figuur 6.26

$\mathrm{S}$ Stimulatie artefact (bij $100 \mathrm{~ms}$ )

Pi $32,6 \mathrm{~ms}$

LF $3 \mathrm{~Hz}$

HF $1600 \mathrm{~Hz}$

pre-stimulusinterval

aantal stimuli

prikkeiduur

prikkelsterkte

frequentie
$100 \mathrm{~ms}$

100

$0,2 \mathrm{~ms}$ $100 \mathrm{~V}$

$1 \mathrm{~Hz}$ 


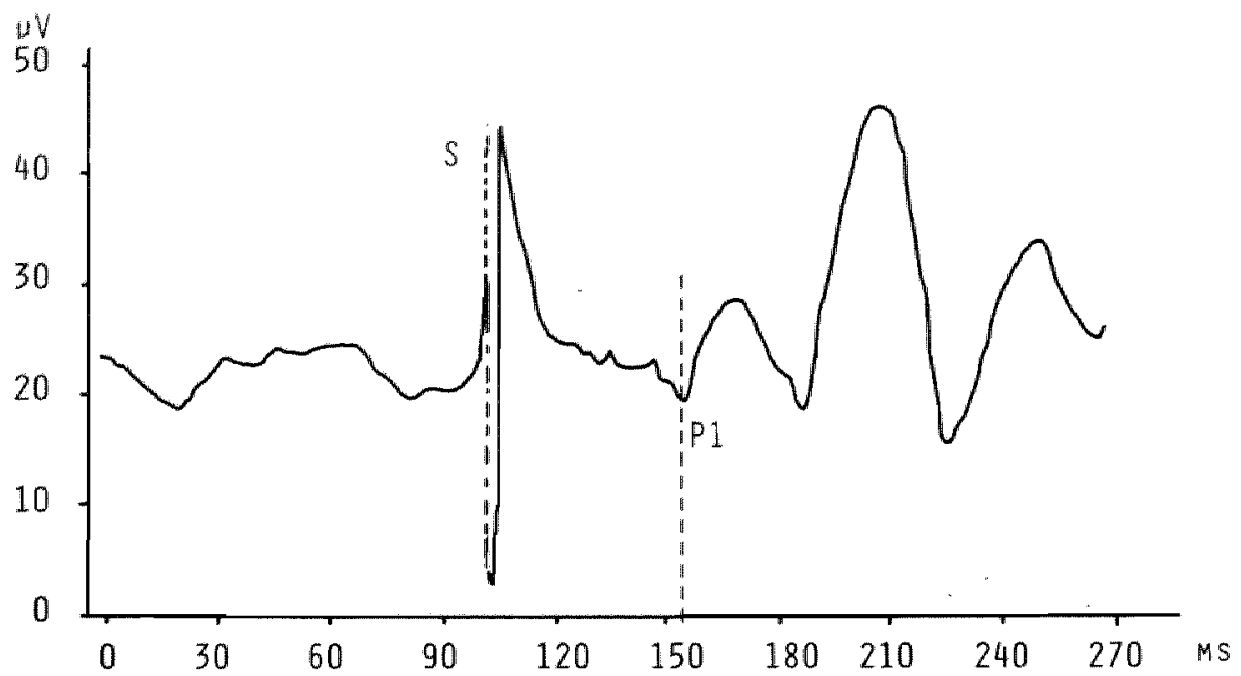

\section{Figuur 6.27}

S Stimulatie artefact (bij $100 \mathrm{~ms}$ )

$P_{1} \quad 55,2 \mathrm{~ms}$

LF $3 \mathrm{~Hz}$

$\mathrm{HF} 1600 \mathrm{~Hz}$

pre-stimulusinterval

aantal stimuli

prikkelduur

prikkelsterkte

frequentie
$100 \mathrm{~ms}$

200

$0,2 \mathrm{~ms}$ $200 \mathrm{~V}$

arantal

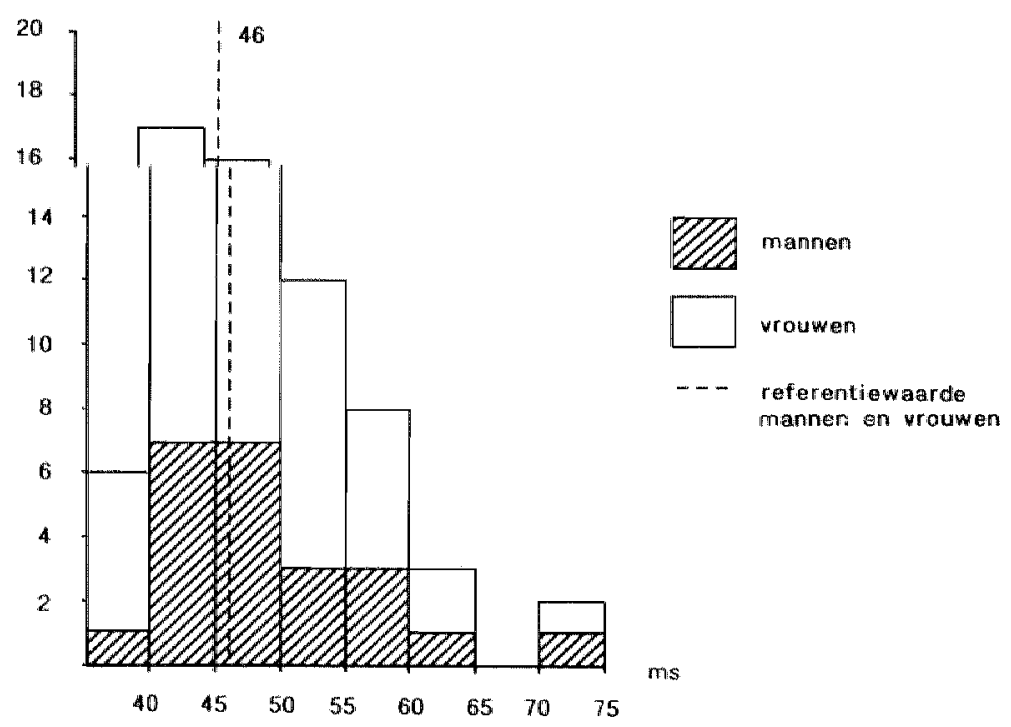

Figuur 6.28

$P_{1}$ - latentietijden TIBIALIS EVOKED POTENTIAL

diabetes mellitus 23 mannen / 41 vrouwen 


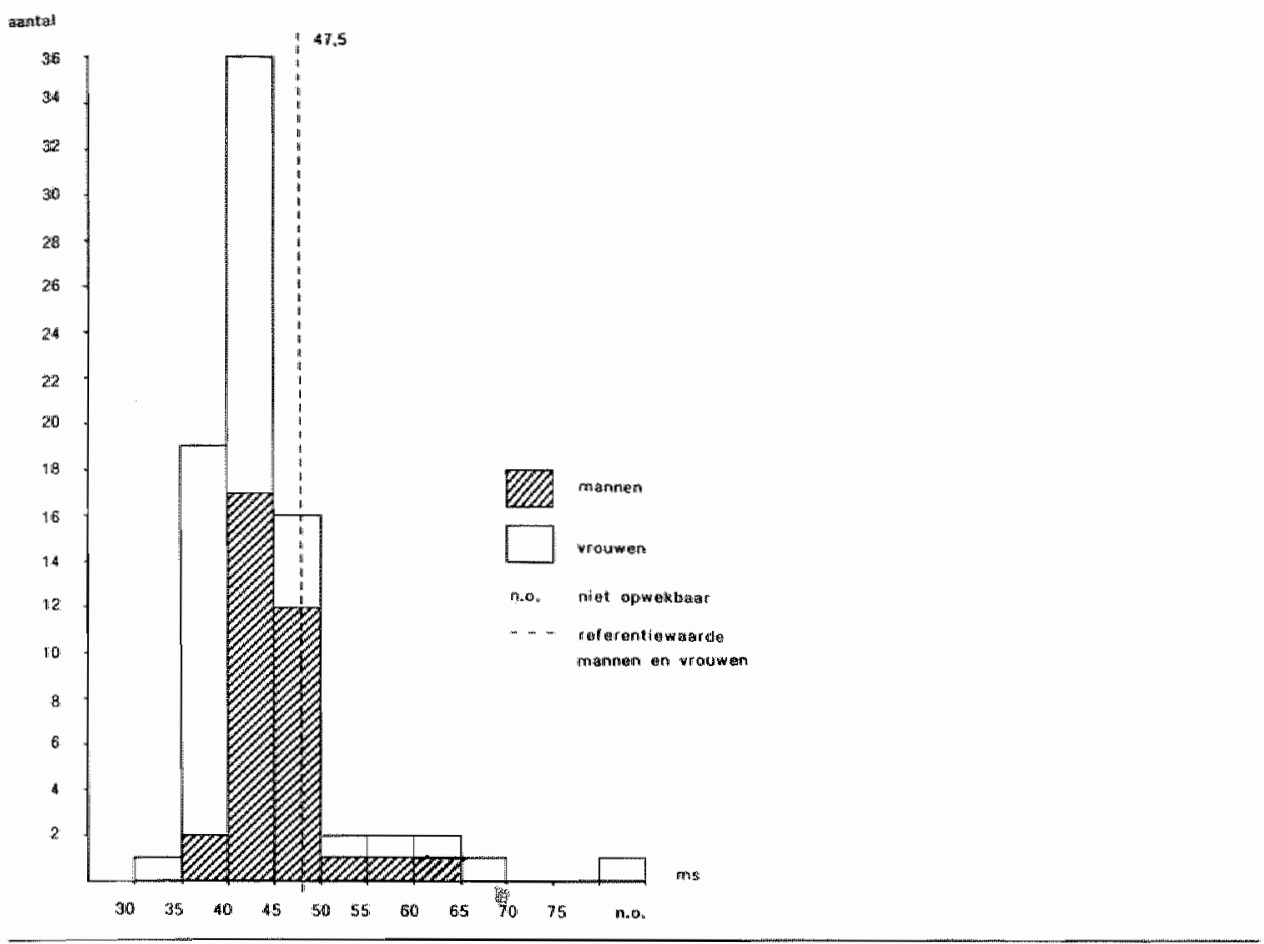

Figuur 6.29

$P_{1}$ - latentietijden PUDENDUS EVOKED POTENTIAL

diabetes mellitus 34 mannen / 46 vrouwen

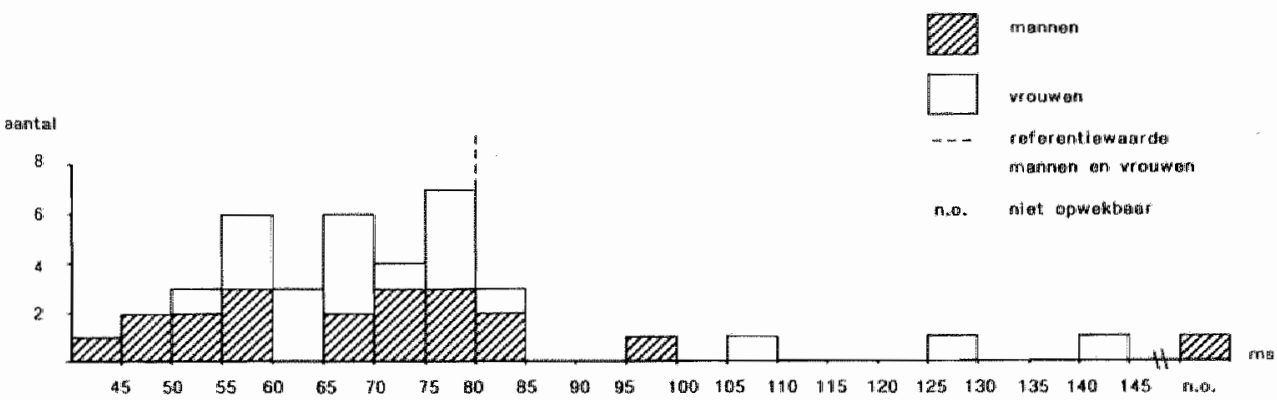

\section{Figuur 6.30}

$P_{1}$ - latentietijden PELVICUS (HYPOGASTRICUS) EVOKED POTENTIAL diabetes mellitus 20 mannen / 20 vrouwen 


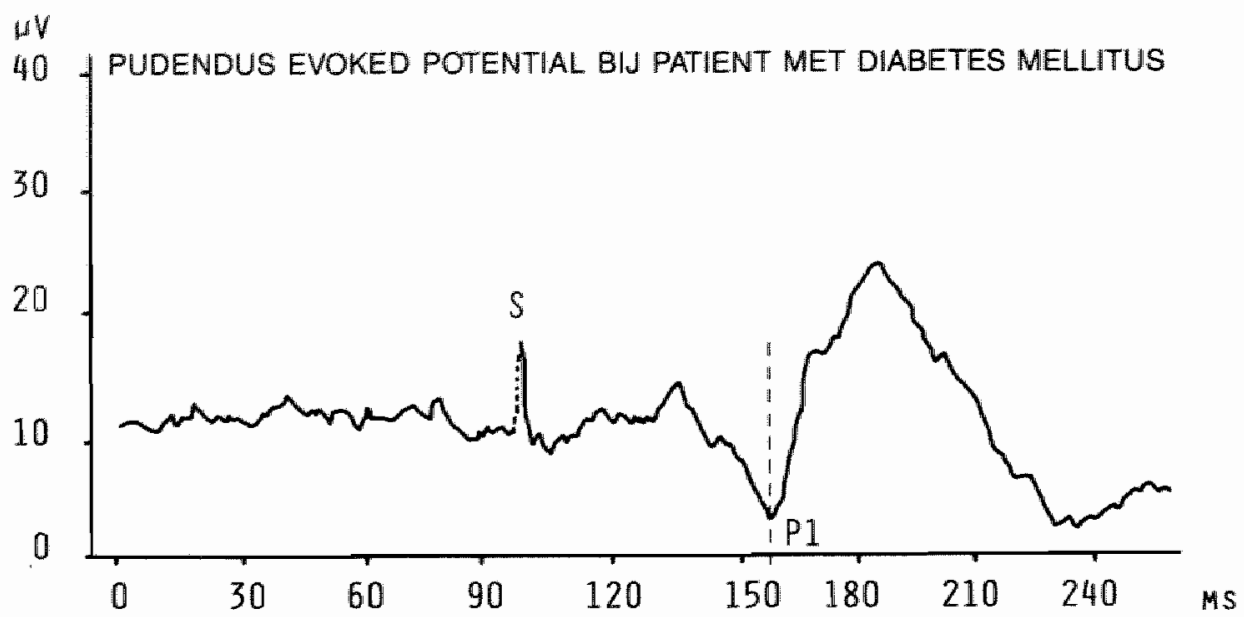

Figuur 6.31

$\mathrm{S}$ Stimulatie artefact (bij $100 \mathrm{~ms}$ )

$P_{1} \quad 58,2 \mathrm{~ms}$

LF $3 \mathrm{~Hz}$

HF $1600 \mathrm{~Hz}$

pre-stimulusinterval

aantal stimuli

prikkelduur

prikkelsterkte

frequentie
$100 \mathrm{~ms}$

100

$0,2 \mathrm{~ms}$

$100 \mathrm{~V}$

$1 \mathrm{~Hz}$

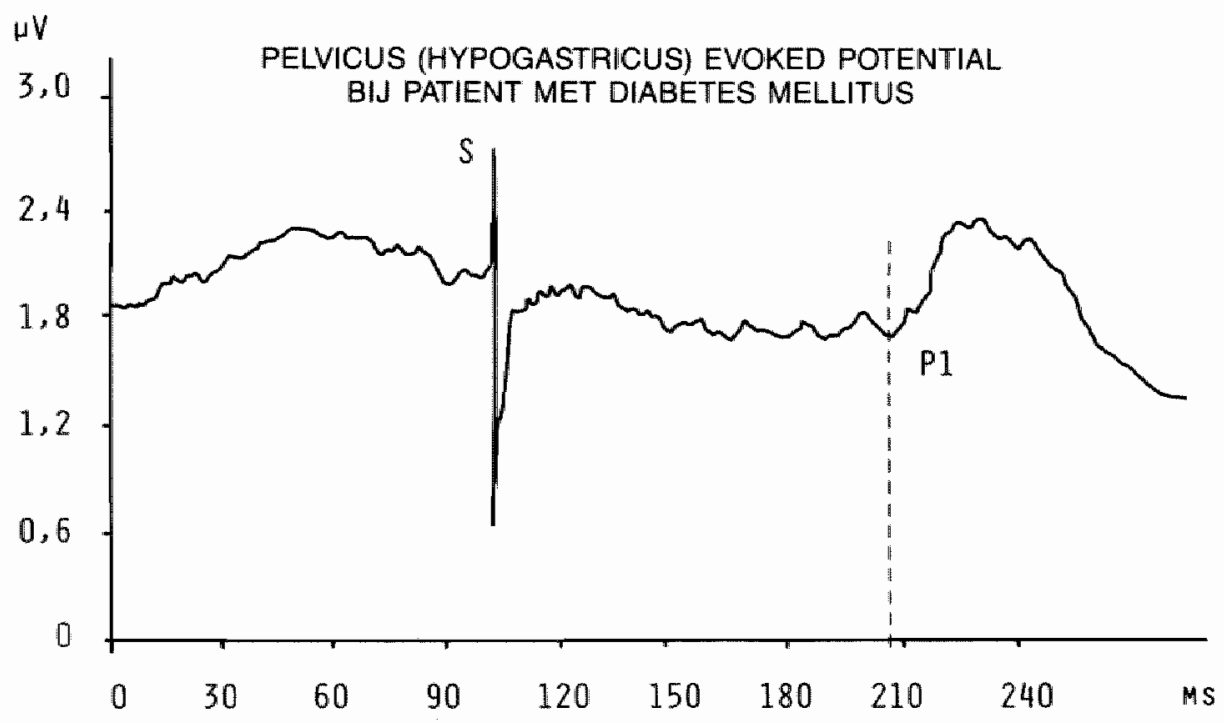

Figuur 6.32

$S$ Stimulatie artefact (bij $100 \mathrm{~ms}$ )

$\mathrm{P}_{1} \quad 107,5 \mathrm{~ms}$

LF $3 \mathrm{~Hz}$

HF $1600 \mathrm{~Hz}$

pre-stimulusinterval

aantal stimuli

prikkelduur

prikkelsterkte

frequentie
$100 \mathrm{~ms}$

200

$0,2 \mathrm{~ms}$

$200 \mathrm{~V}$

$1 \mathrm{~Hz}$ 
Zowel de TEP als de PEP waren athankelijk van de lengte (figuren 6.33 en 6.34) en niet of nauwelijks van de leeftijd.

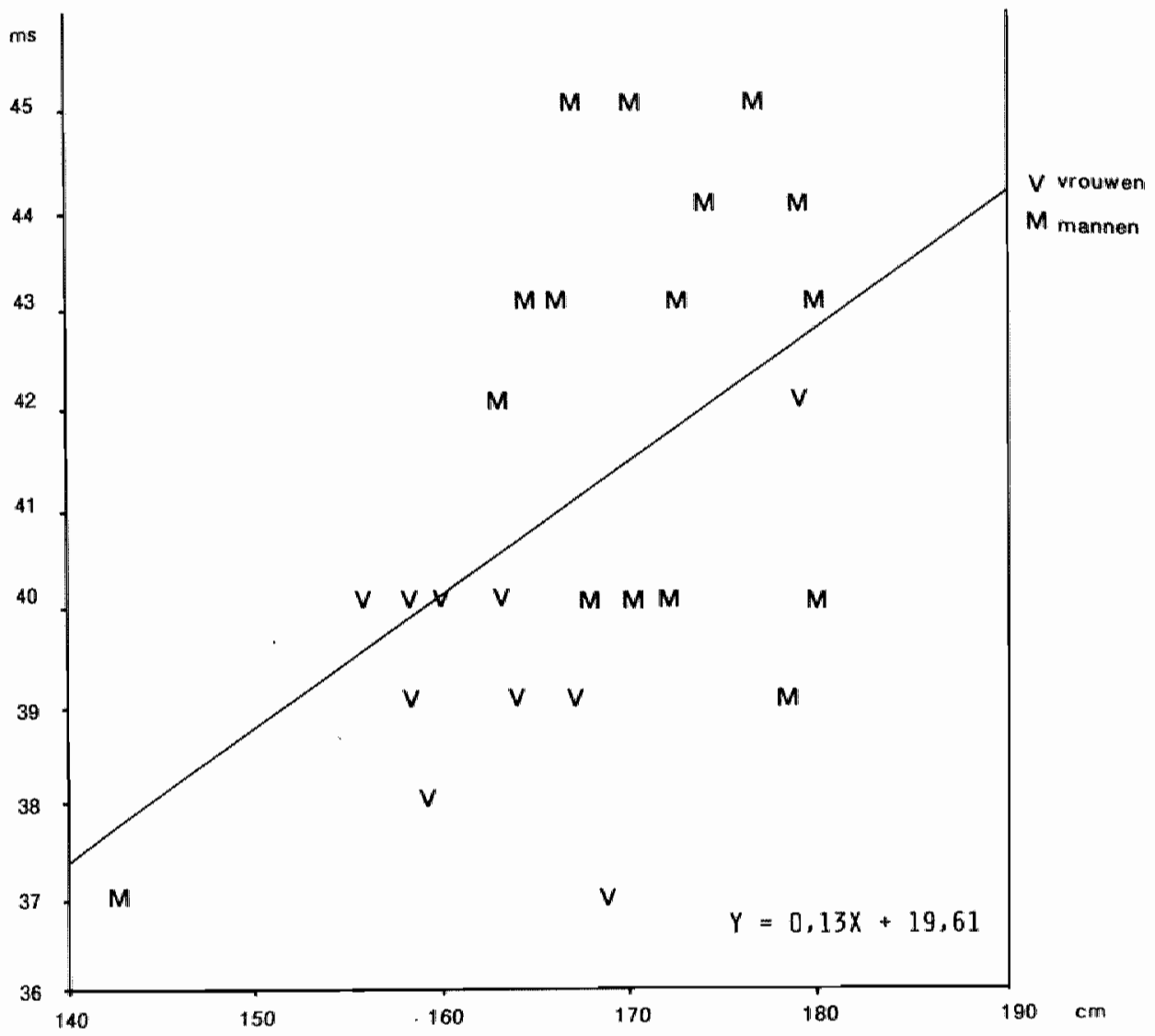

Figuur 6.33

Relatie tussen $P_{1}$ - Iatentietijden TIBIALIS EVOKED POTENTIAL en lichaamslengte bij de referentiegroep $(N=26)$ 

$\checkmark$ wrotiweth
V) mannen
- man en vrouw
V wroumein: 2 x
Marinen $2 \times$
(V) wrouwen $3 x$

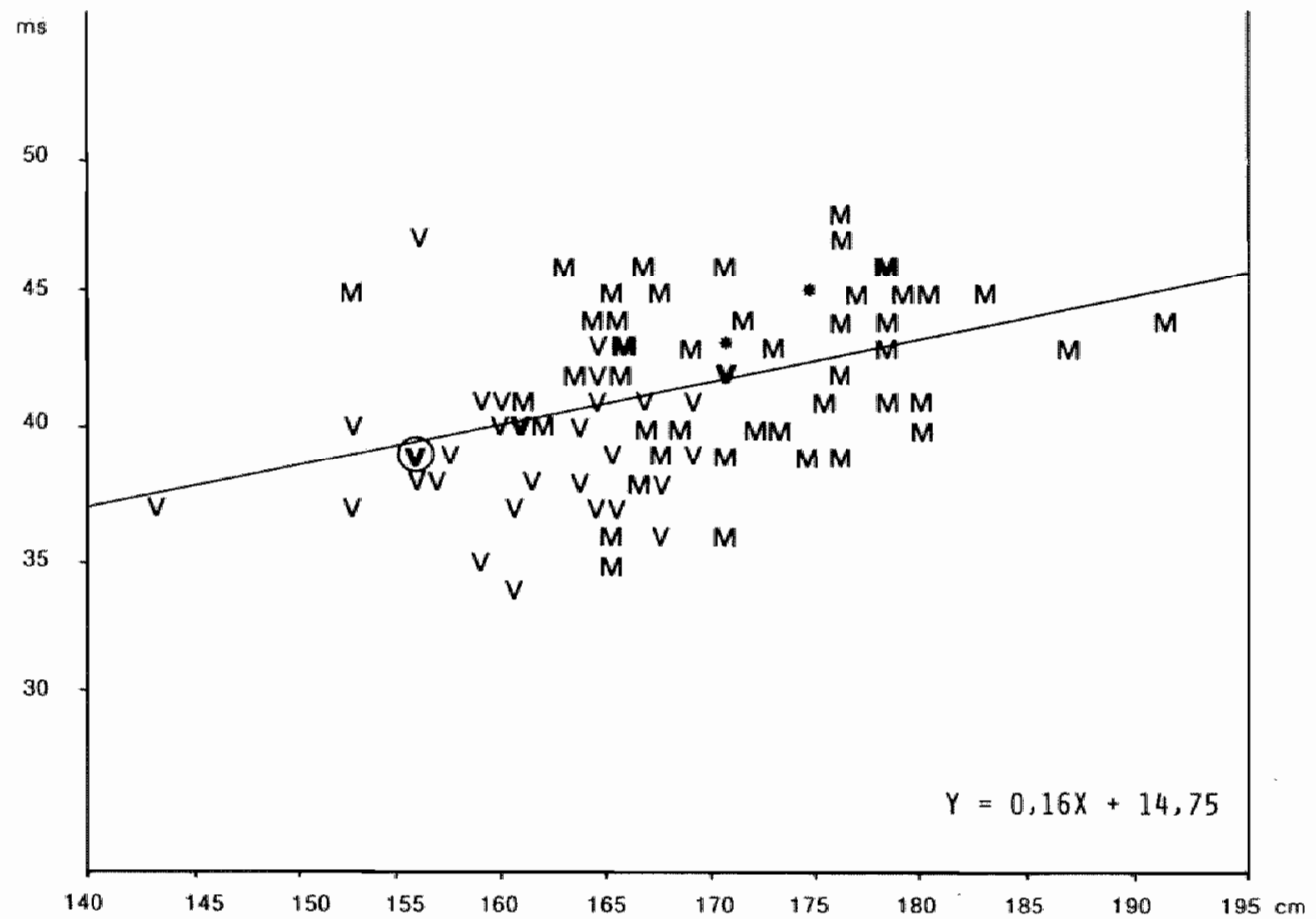

Figuur 6.34

Relatie tussen $\mathrm{P}_{1}$ - latentietijden PUDENDUS EVOKED POTENTIAL en lichaamslengte bij de referentiegroep $(\mathrm{N}=85)$ 


\subsubsection{DISCUSSIE}

De normaalwaarden voor de TEP, PEP en PHEP in onze referentiegroep kwamen goed overeen met de normaalwaarden in de literatuur (zie 4.1.4.4.).

Wij vonden evenals Haldeman et al. (1982) dat de corticale latentietijden van de PEP en de TEP vrijwel gelijk waren.

Haldeman et al. (1982) vonden dat bij normale proefpersonen de gemiddelde latentietild van de PEP bij vrouwen ongeveer 3 ms korter was dan bij mannen.

Wij vonden bij de PEP een verschil van 2,1 ms en bij de PHEP 3,0 ms tussen mannen en vrouwen ( $P<0,001$ ). Dit berust waarschijnlijk op het verschil in lichaamslengte tussen mannen en vrouwen.

Evenals Dorfman (1977) vonden wij een positieve relatie tussen de TEP latentietijd en de lichaamslengte. Dezelfde relatie vondlen wij tussen de PEP latentietijd en de lichaamslengte.

Wij bepaalden bij alle toegepaste evoked potentials de latentietijd van het begin van de stimulus tot de eerste positieve top omdat deze steeds goed herkenbaar was. Dit is het eerste teken van aankomst van de afferente prikkels in de contralaterale schors.

Overeenkomstig de bevindingen van $\mathrm{Haldeman}$ et al. (1982) vonden ook wij dat de amplitudo van de corticale TEP vaak $2 \times$ zo groot was als die van de PEP. Bij onze registraties bleek dat de amplitudo van de corticale PEP vaak $2 \times$ zo groot was als die van de PHEP. Literatuurgegevens betreffende de toepassing van de PEP en de PHEP bij diabetici zijn schaars en betreffen kleine groepen.

Ertekin et al. (1985) vonden zoals eerder beschreven, bij $2(10 \%)$ van de 20 patienten met diabetes mellitus en een erectiestoornis een vertraagde PEP. Wij vonden dit bij $3(15 \%)$ van de 20 onderzochte diabetici met een erectiestoornis.

Welke de mogelijke betekenis is van bovenstaande bevindingen in het kader van urogienitale stoornissen bij diabetici wordt besproken in hoofdstuk 7 .

\subsubsection{ONDERZOEK VAN DE H-REFLEX}

\subsubsection{METHODE}

Wij onderzochten via de methode beschreven in hoofdstuk 4.1.5.3. de H-reflex van de $\mathrm{m}$. soleus.

Deze reflex werd pas later biij het onderzoek betrokken en werd bij 31 mannen (variërend in leeftijd van 28 tot 75 jaar) en 19 vrouwen (variërend in leeftijd van 19 tot 73 jaar) geregistreerd.

Voor stimulatie werden elektrische rechthoekprikkels toegediend met een duur van 0,5 ms en een amplitudo van 100 tot $150 \mathrm{~V}$. De toegepaste stimulatiefrequentie was $0,5 \mathrm{~Hz}$. De prikkelsterkte werd geleidelijk opgevoerd tot een $\mathrm{H}$-reflex of M-respons verscheen. De prikkelsterkte werd opgevoerd tot de amplitudo van de $H$-reflex maximaal was. De latentietijd van de $M$-respons werd gemeten na supramaximale stimulatie van de $n$. tibialis in de fossa poplitea. Bij alle onderzochten werd het $\mathrm{H}-\mathrm{M}$ interval berekend.

Voor de registratie werden twee oppervlakte-elektroden in de mediaanlijin geplaatst boven de spierbuik van de $m$. soleus, $5 \mathrm{~cm}$ van elkaar. De proximale elektrode lag $2 \mathrm{~cm}$ distaal van de onderrand van de spierbuilk van de $\mathrm{m}$. gastrocnemius.

De instelling van de elektromyograaf was als volgt:

- filterbandbreedte van de versterker $16 \mathrm{~Hz}$ tot $1600 \mathrm{~Hz}$

- tijdbasis van 5 - $10 \mathrm{~ms} / \mathrm{div}$

- gevoeligheid van de versterker $200 \mathrm{uV/div}$. 


\subsubsection{RESULTATEN}

De voornaamste onderzoekresultaten worden getoond in tabel 6.6 en figuren 6.35 en 6.36 .

Tabel 6.6

Latentietijd $H$-reflex ( $H$-M interval) bij de referentie- en patientengroe $\rho$

\begin{tabular}{|c|c|c|c|}
\hline & & $\begin{array}{l}\text { Referentie- } \\
\text { groep }\end{array}$ & $\begin{array}{l}\text { Patienten- } \\
\text { groep }\end{array}$ \\
\hline Totaal & $\mathbb{N}$ & 50 & 78 \\
\hline Niet opwekbaar & $\mathbb{N}$ & - & 5 \\
\hline Spreiding latentietijden & & $21-30 \mathrm{~ms}$ & $21-48 \mathrm{~ms}$ \\
\hline Gemiddelde waarde & & $25,1 \mathrm{~ms}$ & $30,8 \mathrm{~ms}^{* *}$ \\
\hline bij mannen en wrouwen & & $(\mathrm{SD} \mathrm{2,0} \mathrm{ms})$ & $(\mathrm{SD} 4,8 \mathrm{~ms})$ \\
\hline mannen & $N$ & $\begin{array}{l}31 \\
25,8 \mathrm{~ms} \\
\text { (SD 1,9 ms) }\end{array}$ & $\begin{array}{l}30 \\
31,5 \mathrm{~ms} \\
\text { (SD } 5,4 \mathrm{~ms})\end{array}$ \\
\hline vrouwen & $N$ & $\begin{array}{l}19 \\
23,8 \mathrm{~ms} \\
\text { (SD } 1,6 \mathrm{~ms})\end{array}$ & $\begin{array}{l}43 \\
30,3 \mathrm{~ms} \\
\text { (SD } 4,2 \mathrm{~ms})\end{array}$ \\
\hline $\begin{array}{l}\text { Afwezige of vertraagde } \\
H \text {-reflex }(>\text { gemiddelde }+2 S D)\end{array}$ & & & $49(63 \%)$ \\
\hline
\end{tabular}

De gemiddelde latentietijd van de $\mathrm{H}$-reflex ( $\mathrm{H}-\mathrm{M}$ interval) was bij de mannen in de referentiegroep significant langer dan bij de vrouwen $(P<0,001)$.

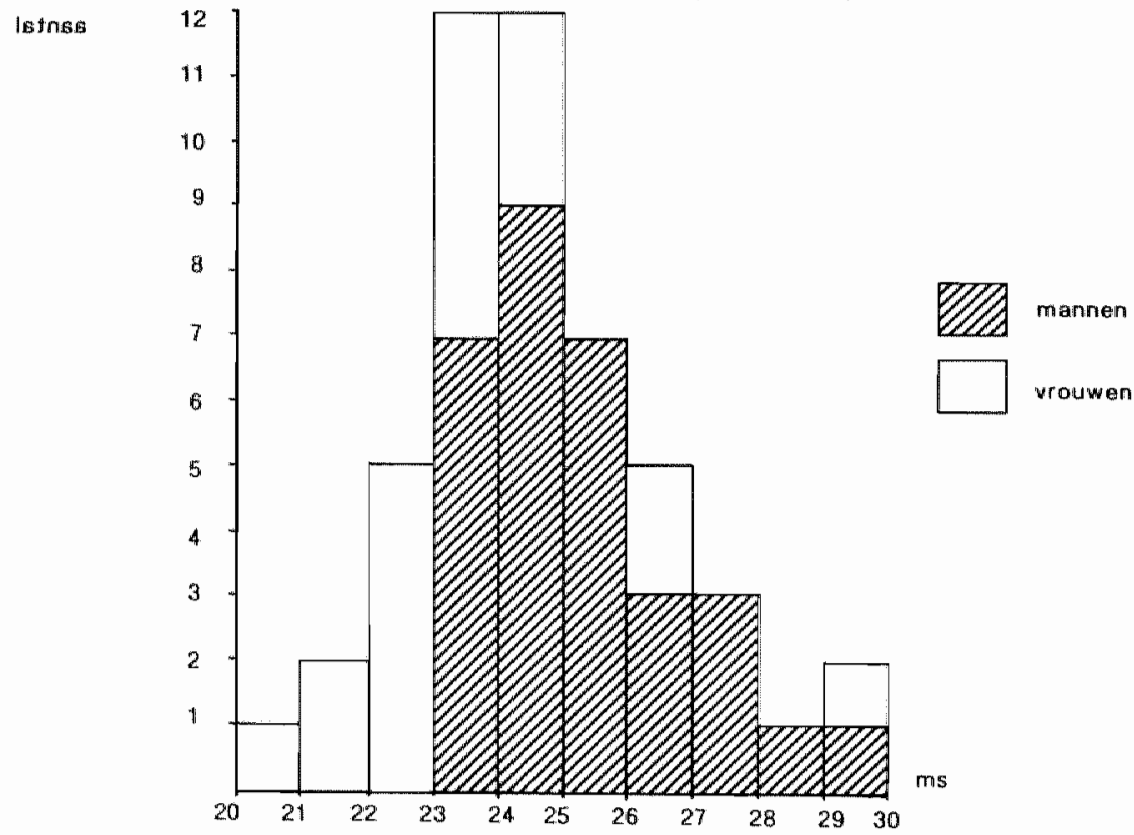

Figuur 6.35

Latentietijden H-REFLEX (H-M interval)

referentiegroep 31 mannen / 19 vrouwen 
aratial

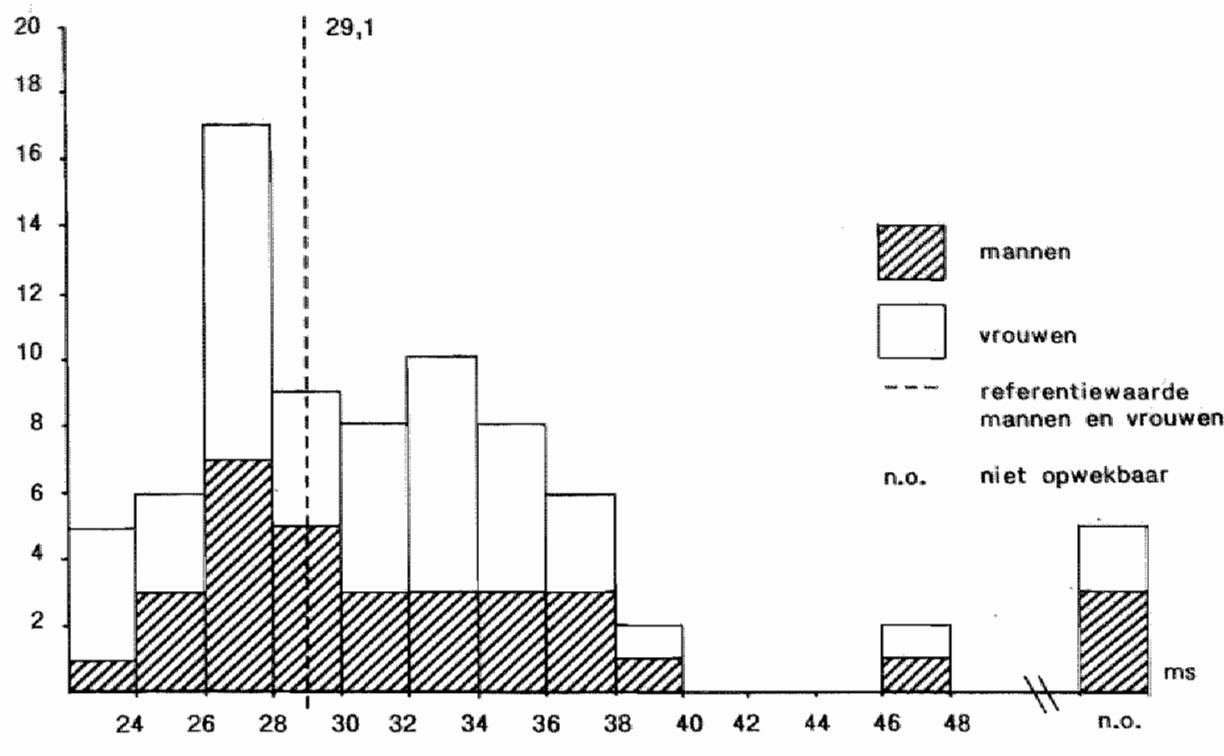

\section{Figuur 6.36}

Latentietijden H-REFLEX (H-M interval)

diabetes mellitus 33 mannen / 45 vrouwen

De latentietijd van het $\mathrm{H}-\mathrm{M}$ interval was afhankelijk van de lichaamslengte (figuur 6.37). De stimulatiedrempel van de H-reflex was bij het grootste deel van de door ons onderzochte diabetici toegenomen en bij een aantal diabetici verscheen de $\mathrm{H}$-reflex bij dezelffe of bij hogere stimulatie dan de M-respons. De vorm van de $\mathrm{H}$-reflex was in veel gevallen polyfasisch.

Bij een deel van de onderzochte diabetici werd een F-respons geregistreerd.

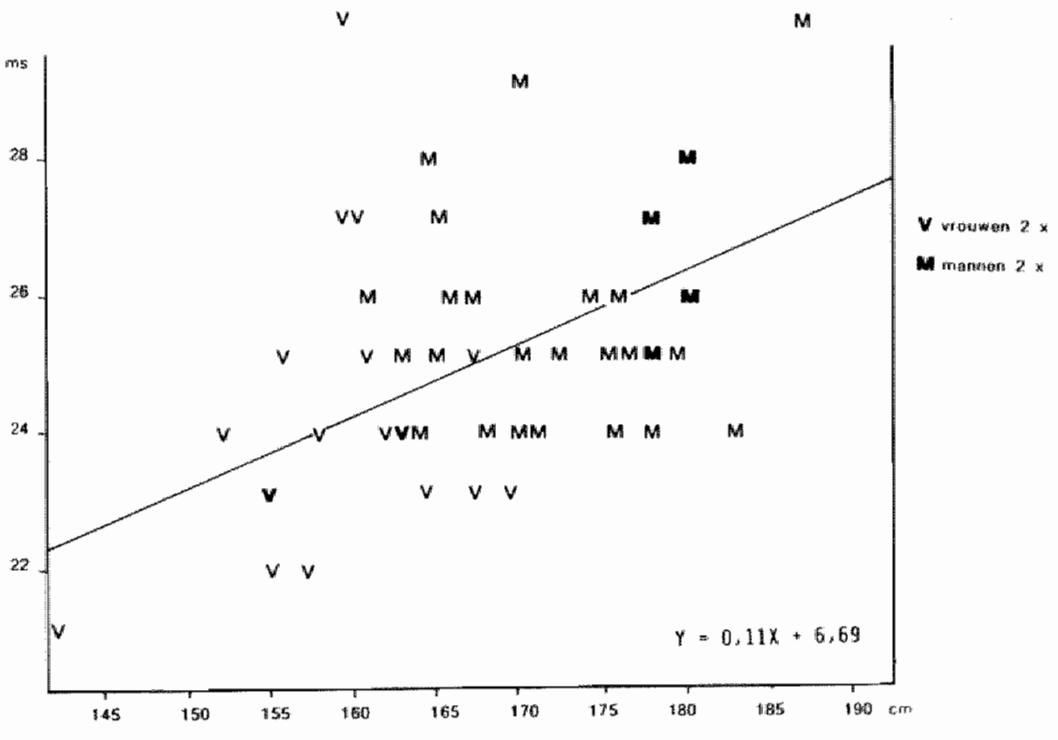

Figuur 6.37

Relatie tussen latentietijden H-M interval en lichaamslengte bij de referentiegroep $(\mathrm{N}=50)$ 


\subsubsection{DISCUSSIE}

De normaalwaarden van het $H-M$ interval in onze referentiegroep kwamen goed overeen met de normaalwaarden in de literatuur (zie 4.1.5.4.).

Notermans et al. (1977) vonden bij $77 \%$ van de 40 patienten met diabetes mellitus, die aselect werden gekozen, een verlengd $H-M$ interval. Berteismann et al. (1986) vonden bij $91,2 \%$ van de insuline afhankelijke diabetici met symptomen van een neuropathie en bij $62.5 \%$ van insuline afhankelijke diabetici zonder symptomen van een neuropathie een verlengd $\mathrm{H}-\mathrm{M}$ intervall.

Wil vonden een afwezige $\mathrm{H}$-reflex of een verlengd $\mathrm{H}-\mathrm{M}$ interval $(>$ gemiddelde $+2 \mathrm{SD}$ ) bij 49 onderzochte diabetici ( $63 \%$ ).

Notermans et al. (1977) vonden evenals wij dat bij diabetici de stimulatiedrempell van de $\mathrm{H}$-reflex toegenomen was en dat bij een aantal diabetici de $\mathrm{H}$-reflex bij dezelfde of bij hogere stimulatie dan de M-respons verscheen. Ook de vorm van de $\mathrm{H}$-reflex was in vele gevallen polyfasisch met een lage amplitudo.

Welke de mogelijke betekenis is van bovengenoemde bewindingen in het kader van urogenitale stoornissen bij diabetici wordt besproken in hoofdstuk 7 .

\subsection{REGRESSIE VAN DE LATENTIETIJD VAN H-REFLEX, TEP EN PEP OP BASIS VAN GESLACHT, LENGTE EN LEEFTIJD BIJ DE REFERENTIEGROEP}

In tabel 6.5 en 6.6 werden verschillen gerapporteerd in latentietijden voor $\mathrm{H}$-reflex $(\mathrm{H}-\mathrm{M}$ interval), TEP en PEP tussen mannen en vrouwen. Hier wordt nagegaan of deze verschillen te verklaren zouden kunnen zijn door verschillen in lengte en leeftijd tussen de mannen en vrouwen in de referentiegroep.

In tabell 6.7 zijn de regressiecoëfficiënten gegeven zoals geschat via lineaire regressieanalyse met drie verschillende modellen: alleen met geslacht als verklarende variabele (model 1), respectievelijk met geslacht en lengte (model 2) en met geslacht, lengte en leeftijd (model 3) als verklarende variabelen.

De verschillen in latentietijden tusen mannen en vrouwen, zoals vermeld in de kolom onder 'model 1' komen overeen met de waarden in tabel 6.5 en 6.6 .

Voor de H-reflex blijkt dat het verschil in latentietijd tussen mannen en vrouwen deels verklaard wordt door verschillen in lengte (model 2) en deels door verschillen in leeftijd (model 3). Na correctie voor deze verschillen blijft er (vrijwel) geen verschil in latentietijd $(0,06$ ms) tussen mannen en vrouwen meer over.

Op het verschil in latentietijden voor de TEP en PEP tussen mannen en vrouwen heeft correctie voor lengte- en leeftijdsverschillen een veel minder grote invloed. Er lijkt voor de PEP en wellicht voor de TEP een werkelijk effect van geslacht op de latentietijden te bestaan. 
Regressieanalyse van de latentietijden van H-reflex,

TEP en PEP op basis van geslacht, lengte en leeftijd bij de referentiegroep (regressiecoëfficienten met P-waarden)

\begin{tabular}{|c|c|c|c|c|}
\hline & eenheden & model 1 & model 2 & model 3 \\
\hline & & $\mathrm{H}$-reflex $(\mathrm{H}$ & terval) & $=50$ \\
\hline $\begin{array}{l}\text { Geslacht * } \\
\text { Lengte } \\
\text { Leeftijd }\end{array}$ & $\begin{array}{l}\mathrm{ms} \\
\mathrm{ms} / \mathrm{cm} \\
\text { ms/jaar }\end{array}$ & $2,0(0,00)$ & $\begin{array}{l}0,96(0,10) \\
0,07(0,04)\end{array}$ & $\begin{array}{l}0,06(0,47) \\
0,10(0,01) \\
0,07(0,01)\end{array}$ \\
\hline & & & $N=$ & 26 \\
\hline $\begin{array}{l}\text { Geslacht * } \\
\text { Lengte } \\
\text { Leeftijd }\end{array}$ & $\begin{array}{l}\mathrm{ms} \\
\mathrm{ms} / \mathrm{cm} \\
\text { ms/jaar }\end{array}$ & $3,3(0,00)$ & $\begin{array}{c}3,74(0,00) \\
-0,04(0,30)\end{array}$ & $\begin{array}{l}1,94(0,09) \\
0,06(0,25) \\
0,09(0,03)\end{array}$ \\
\hline & & & $N=$ & 85 \\
\hline $\begin{array}{l}\text { Geslacht * } \\
\text { Lengte } \\
\text { Leeftijd }\end{array}$ & $\begin{array}{l}\mathrm{ms} \\
\mathrm{ms} / \mathrm{cm} \\
\mathrm{ms} / \mathrm{jaar}\end{array}$ & $3,1(0,00)$ & $\begin{array}{l}2,07(0,01) \\
0,09(0,02)\end{array}$ & $\begin{array}{l}1,99(0,02) \\
0,09(0,02) \\
0,01(0,42)\end{array}$ \\
\hline
\end{tabular}

* latentietijd bij mannen minus latentietijd bij vrouwen.

\subsubsection{SAMENVATTING RESULTATEN KLINISCH-NEUROFYSIOLOGISCH ONDERZOEK BIJ REFERENTIE- EN PATIENTENGROEP}

Bij $16 \%$ van de patientengroep en slechts bij $2 \%$ van de referentiegroep werd in rust geen MU-aktiviteit gevonden bij het EMG onderzoek van de $\mathrm{m}$. sphincter ani externus. Het ontbreken van basisaktiviteit is een teken van een gestoorde innervatie van de $m$. sphincter ani externus. Bij $56 \%$ van de patientengroep en bij $2 \%$ van de referentiegroep werd een verminderd maximaal aanspanningspatroon gevonden. Er bleek een duidelijke relatie te bestaan tussen de mate van spontane MU-aktiviteit en het maximaal aanspanningspatroon.

Fibrillatie potentialen werden in de patientengroep bij $14 \%$ en in de referentiegroep niet gevonden. Deze patienten toonden allen geen spontane MU-aktiviteit en een verminderd maximaal aanspanningspatroon.

Bij $6 \%$ van de referentiegroep werden complexe repetitieve ontladingen vastgesteld waarvoor geen neurologische verklaring.

In de referentiegroep waren de gemiddelde latentietijden van de PEP, TEP, H-reflex (H-M interval) en BCR II $\mathrm{m}$. sphincter ani externus bij mannen significant langer dan bij vrouwen.

Het verschil in latentietijd van de $\mathrm{H}$-reflex tussen mannen en vrouwen word grotendeels bepaald door lengte en leeftijd van de proefpersonen. Op de latentietijd van de TEP en de PEP hebben lengte, leeftijd en geslacht invloed.

Voor alle toegepaste neurofysiologische tests behalve de BCR II $\mathrm{m}$. bulbocavernosus werden bij de diabetici gemüddeld significant langere latentietijden gevonden in vergelijking metl de referentiegroep. 


\subsubsection{INLEIDING}

Alle onderzochte diabetici ondergingen in het kader van dit onderzoek, naast de neurofysiologische metingen, een urodynamisch en indien geïndiceerd een cystoscopisch onderzoek.

Dit urodynamisch en cystoscopisch onderzoek werd steeds in een korte tijdsspanne ná en soms ook vóór het neurofysiologisch onderzoek uitgevoerd op de afdeling urologie doar de urologen Dr. L.H. Cuypers en later ook Drs. F.A. Asin.

Zij waren niet op de hoogte van onze onderzoekbevindingen.

Bij de cystoscopie werd gelet op: anatomische infravesicale obstructie trabekulatie van de blaaswand aanwezigheid van een cystocele.

Bij het urodynamisch onderzoek werden de volgende metingen verricht:

residu

blaascapaciteit

eerste aandrang

detrusorgedrag: - hypotoon

- normaal

- hypertoon

incontinentie: - geen

- zonder detrusorcontractie (= stressincontinentie)

- met detrusorcontractie

maximale mictiedruk

uroflowmetrie

Van het mictiecysto-urethrogram werd geen gebruik gemaakt.

\subsubsection{CYSTOSCOPIE}

\subsubsection{METHODE}

Dit onderzoek vond plaats nadat de blaas lichtelijk gevuld was met vocht. Gelet werd op de eventuele aanwezigheid van urineretentie na de mictie, op het aspect van blaas- en urethraslijmvlies, op de ureterostia en op de aanwezigheid van trabekulatie van de blaaswand. Speciaal werd ook gelet op een obstructie van de urethra prostatica.

Bij onze patienten werd een cystoscopie verricht indien de klachten, het urodynamisch onderzoek of andere bevindingen, aanwijzingen toonden voor de aanwezigheid van nietneurogene pathologie. Bij mannen waren klachten van moeilijke of frequente mictie voldoende reden am een eventuele infravesicale obstructie (prostaathypertrofie, urethrastrictuur) op te sporen. Hetzelfde gold indien bij urodynamisch onderzoek een urineretentie werd vastgesteld of indien bij rectaal onderzoek de prostaat vergroot bleek te zijn.

Verdere urologische evaluatie (intraveneuze pyelografie eventueel gevolgd door cystoscopie) volgde ook indien in het urinesediment een leucocyturie of erythrocyturie werd vastgesteld. 


\subsubsection{RESULTATEN}

Anatomische infravesicale obstructie

58 mannelijke en vrouwelijke diabetici ondergingen een cystoscopisch onderzoek. 12 patienten (allen mannen) toonden wel en 46 geen infravesicale obstructie. De leef* tijden van de patienten met een obstructie varieerden van 50 tot 77 jaar.

\section{Trabekulatie van de blaaswand}

10 patienten toonden een min of meer uitgesproken trabekulatie van de blaaswand en 48 hadden geen trabekelblaas.

Cystocele

3 patienten vertoonden een cystocele.

\subsubsection{DISCUSSIE}

Frimodt-Mgller (1978) vond een infravesicale obstructie bij $26 \%$ van de door hem onderzochte diabetici boven de 56 jaar. Wij vonden bij $15 \%$ van de 80 onderzochte diabetici een infravesicale obstructie. Dit waren allen mannen van 50 jaar en ouder. Lytton et al. (1968) berekenden dat de kans dat een 40-jarige man, bij een levensverwachting van 80 jaar, een operatie zal ondergaan van de prostaat in verband mett een benigne prostaathypertrofie, $10 \%$ bedraagt. Birkhoff (1983) schatte de kans op een prostaatoperatie bij een 50 -jarige man, bij een llevensverwachting van 80 jaar, $20-25 \%$.

Lich en Grant (1948) zagen bij 43\% en loanid et al. (1981) zelfs bij alle onderzochte diabetici met klinische problematiek, een geringe trabekulatie. Wij zagen bij 10 patienten $(12,5 \%)$ een min of meer uitgesproken trabekulatie van de blaaswand.

\subsubsection{URODYNAMISCH ONDERZOEK}

\subsubsection{METHODE}

Twee katheters werden in de blaas gebracht via de urethra, een wullingskatheter Ch8 en een drukmetende katheter Ch6. Tevens werd rectaal een katheter Ch12 ingebracht voor het meten van de intra-abdominale druk. Een bipolaire naaldelektrode werd gebruikt voor het registreren van het elektromyogram van de $\mathrm{m}$. sphincter ani externus.

De patient werd in zittende houding gebracht. Terwijl de blaas gevuld werd met fysiologisch zout ( $100 \mathrm{ml} / \mathrm{min}$ ) werd continu de druk gemeten in de blaas en in het rectum. Gedurende de blaasvulling werd de patient verzocht af en toe te hoesten. De aldus veroorzaakte abrupte verhoging van de intra-abdominale en intravesicale druk kan niet alleen een insufficiënt sphincterapparaat aantonen (stress incontinentie), maar kan ook onstabiele blaascontracties provoceren, die anders mogelijk niet tot uiting zouden zijn gekomen. De patient gaf aan wanneer hij de eeste aandrang tot mictie voelt, meestal bij een blaasvulling van $200-300 \mathrm{ml}$.

Wanneer tegen het einde van de wulling een heftig aandranggevoel ontstond moest de patient aantonen of hij in staat was de mictiecontractie te onderdrukken. Wanneer de volledige blaascapaciteit bereikt was, gaf de patient toe aan de mictiedrang. Tijdens de vulling en ook gedurende de mictie werden de intravesicale druk, de intra-abdominale druk en het sphincterelektromyogram geregistreerd. Tevens werd de urine opgevangen in een flowmeter.

in sommige gevallen werd de flow geregistreerd los van het cystometrogram en zonder vullings- of mictiekatheters. 
De gebruikte apparatuur was van Disa. Registratie vond plaats middels vijf kanalen: elektromyogram van de $\mathrm{m}$. sphincter ani externus, vullingsgraad van de blaas, flow, intravesicale druk en intra-abdominale druk. De intrinsieke blaasdruk werd berekend door de intra-abdominale druk van de intravesicale druk af te trekken. Figuur 6.38 geeft schematisch weer hoe bij het urodynamisch onderzoek de apparatuur werd opgesteld, op welke plaatsen (blaas, rectum, $m$. sphincter ani externus, flowmeting) de metingen werden verricht en hoe, na elektronische verwerking, deze gegevens als curves onder elkaar simultaan werden opgetekend.

\subsubsection{RESULTATEN}

De voornaamste resultaten van het urodynamisch onderzoek worden weergegeven in tabel 6.8 en figuren $6.38 \mathrm{t} / \mathrm{m} 6.42$.

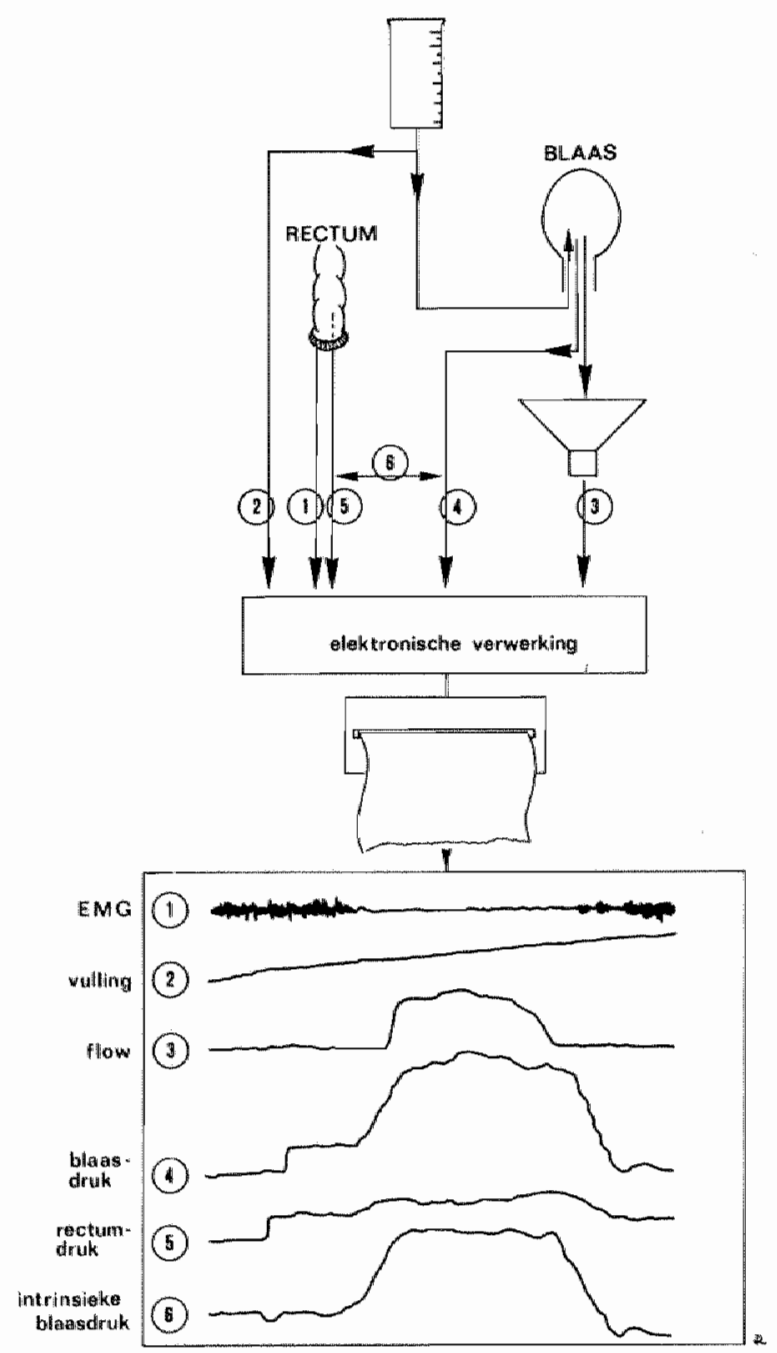

Figuur 6.38

Opstelling urodynamische apparatuur, plaats van meting en registratie van curves na elektronische verwerking. 
Resultaten urodynamische parameters bij de patientengroep

Residu

Gehanteerde normaalwaarde

Spreiding

Gemiddelde waarde

Afwijkende waarden

Blaascapaciteit

Gehanteerde normaalwaarde

Spreiding

Gemiddelde waarde

Afwijkende waarden $<250 \mathrm{ml}$

$>600 \mathrm{ml}$

Eerste aandrang

Gehanteerde normaalwaarde

Spreiding

Gemiddelde waarde

Afwijkende waarden $<50 \mathrm{ml}$

$>300 \mathrm{ml}$

Detrusorgedrag

Hypotoon

Normaal

Hypertoon

Incontinentie

Geen

Zonder detrusorcontractie

Met detrusorcontractie

Maximale mictiedruk

Gehanteerde normaalwaarde

Spreiding (totaal)

Gemiddelde waarde

Mannen (zonder infravesicale obstructie) Vrouwen (zonder infravesicale obstructie)

Mannen (met infravesicale obstructie)

Uroflowmetrie (maximal flow rate)

Gehanteerde normaalwaarde mannen

vrouwen

Spreiding (totaal)

Gemiddelde waarde

Mannen (zonder infravesicale obstructie) Vrouwen (zonder infravesicale obstructie)

Afwijkende waarden mannen $>20 \mathrm{ml} / \mathrm{s}$ vrouwen $>30 \mathrm{ml} / \mathrm{s}$
13

80

11

19

80

2

20

19

46

15

50

11

19

69

21
38
10

71

22

39

1

$N$

$<10 \%$ van de blaascapaciteit $0.2000 \mathrm{ml}$

$62 \mathrm{ml}(\mathrm{SD} 239 \mathrm{ml}$ ) $18 \%$

250-600 ml

$40-1000 \mathrm{ml}$ $490 \mathrm{ml}$ (SD $208 \mathrm{ml}$ )

$14 \%$

$24 \%$

50-300 $\mathrm{ml}$

$30-750 \mathrm{ml}$

$259 \mathrm{ml}$ (SD $142 \mathrm{ml}$ )

$2,5 \%$

$25 \%$

$24 \%$

$57 \%$

$19 \%$

$62 \%$

$14 \%$

$24 \%$

25-80 cm water

$10-120 \mathrm{~cm}$ water

$40,1 \mathrm{~cm}$ water

(SD $24,3 \mathrm{~cm}$ water)

10-120 cm water

$10-50 \mathrm{~cm}$ water

$10-120 \mathrm{~cm}$ water

$\pm 20 \mathrm{ml} / \mathrm{s}$

$\pm 30 \mathrm{~m} / / \mathrm{s}$

$2-42 \mathrm{ml} / \mathrm{s}$

$12,7 \mathrm{ml} / \mathrm{s}(\mathrm{SD} 6,0 \mathrm{ml} / \mathrm{s})$

4-21 m//s

$2-42 \mathrm{ml} / \mathrm{s}$

$4.5 \%$

$3 \%$ 
andal

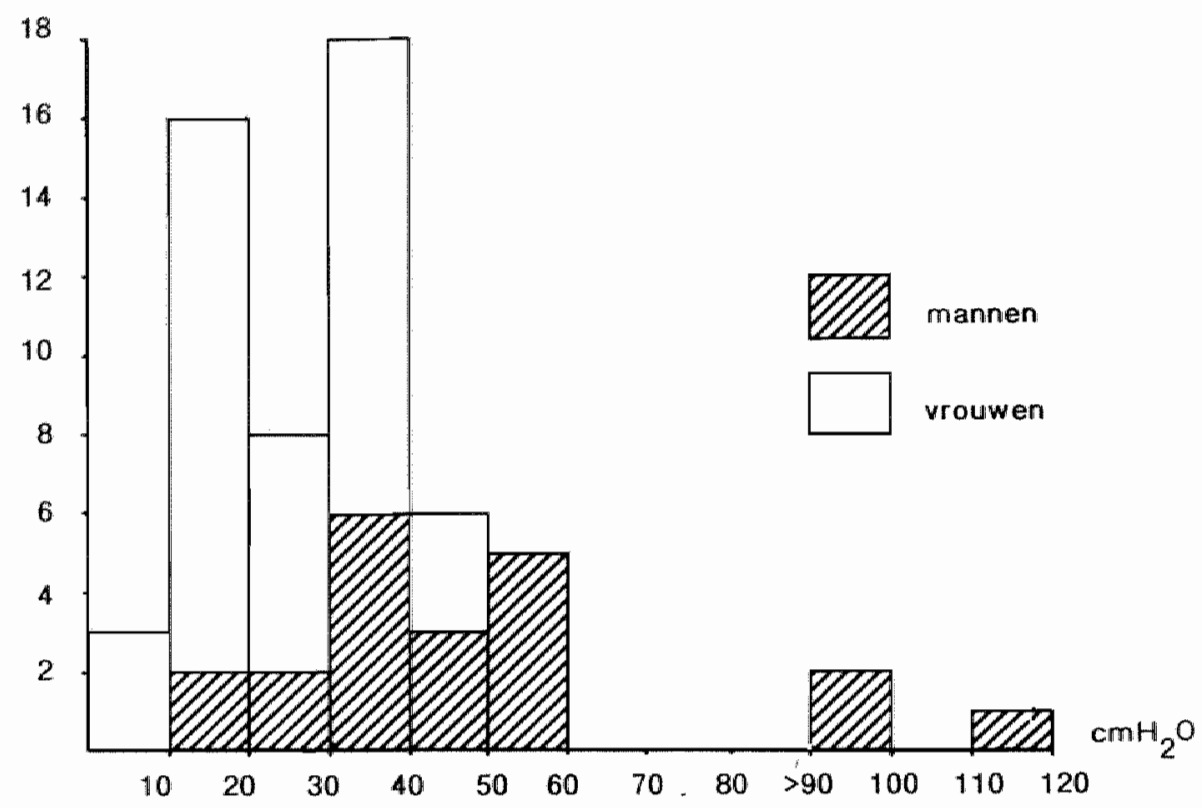

Figuur 6.39

Maximale mictiedruk bij 21 mannelijke en 38 vrouwelijke diabetici zonder infravesicale obsturctie

aantal

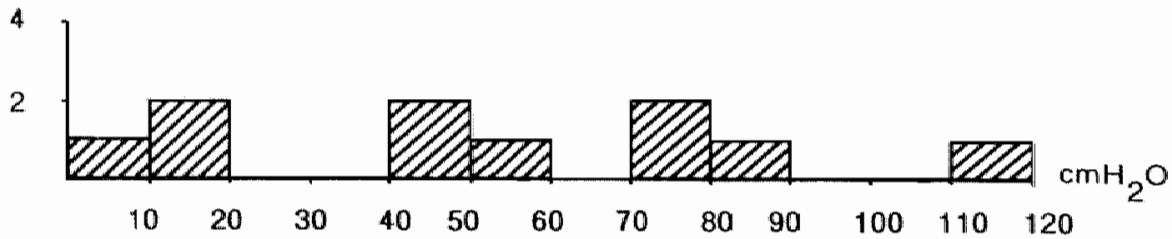

Figuur 6.40

Maximale mictiedruk bij 10 mannelijke diabetici met infravesicale obstructie 
aantal

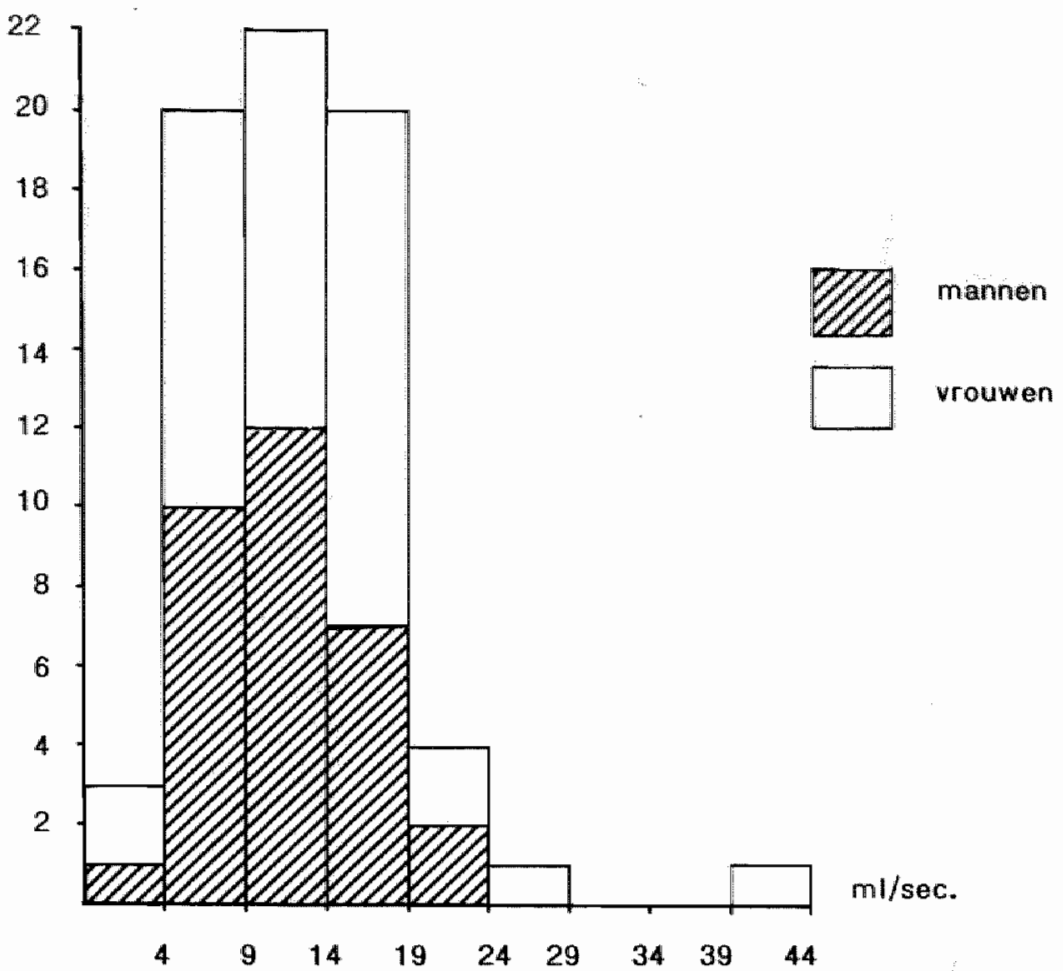

Figuru 6.41

Maximale flow rate bij 39 vrouwelijke en 32 mannelijke diabetici met en zonder infravesicale obstructie

aantal

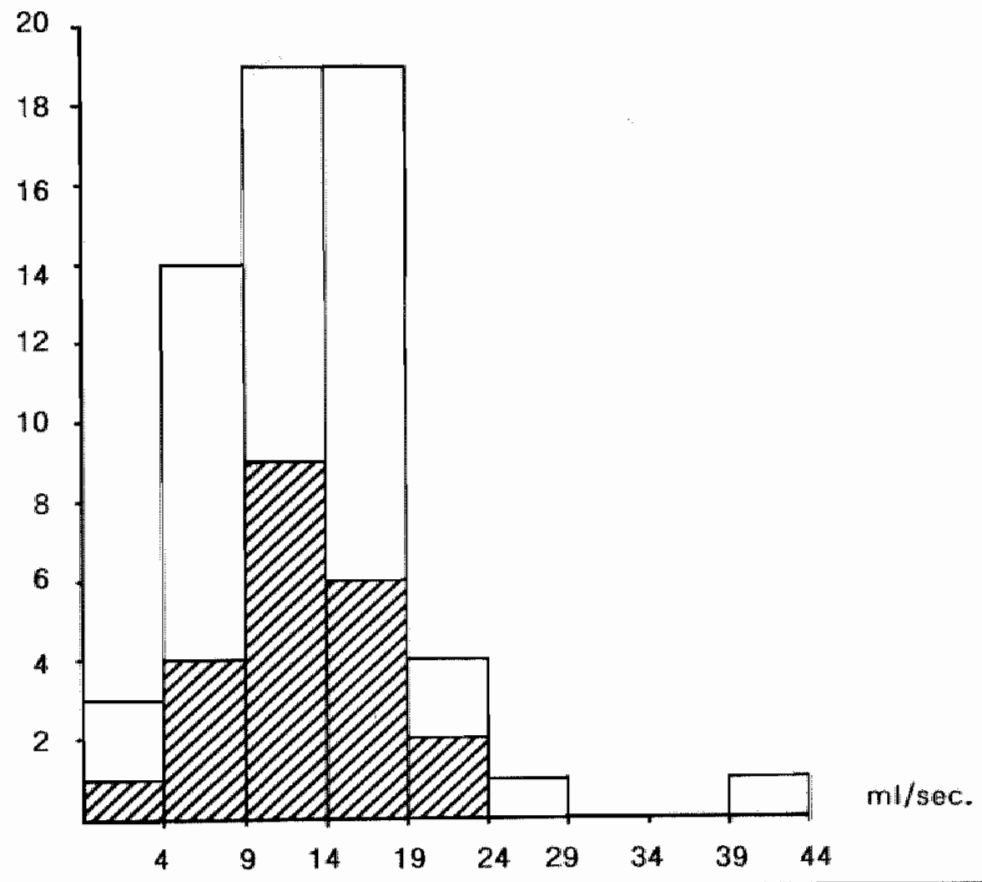

Figuur 6.42

Maximale flow rate bij 39 vrouwelijke en 22 mannelijke diabetici

zonder infravesicale obstructie 
Met betrekking tot het detrusorgedrag zij vermeld dat de detrusorcurve bij de patientengroep doot de urologen werd geregistreerd en ingedeeld in hypotoon, normaal en hypertoon. Het aspect van de cystometrische curve was vaak karakteristiek. Wij spraken van hypotoon indien de curve lang en vlak was en van hypertoon indien de curve kort was met grillige pieken.

Het betrof hier patienten met en zonder infravesicale obstructie en zonder urineweginfectie.

\subsubsection{DISCUSSIE}

Wij stelden overeenkomstig Bors (1957) dat het blaasresidu pathologisch was wanneer dit groter was dan 10\% van de blaascapaciteit en vonden dit bij 18\% van de onderzochte diabetici. Frimodt-Mgller (1976a) vond een pathologisch residu bij bijna de helft van de onderzochte diabetici met een cystoneuropathie. Ellenberg (1966), Faerman (1971) en Frimodt-Mgller (1976a) vonden een residu dat varieerde van 0 tot $3500 \mathrm{ml}$. Dit komt goed overeen met onze bevindingen.

Hopkins en Pierce (1967) en Kahan et al. (1970) vonden door middel van cystometrisch onderzoek bij patienten met een diabetische cystoneuropathie, een toegenomen blaascapaciteit. Er was verschil van mening over de grens tussen een normale en een pathologisch verhoogde blaascapaciteit. Dit varieerde bij de verschillende studies van $400 \mathrm{mil}$ (Kahan et al., 1970) tot $700 \mathrm{ml}$ (Hopkins en Pierce, 1967). Wij beschouwden een blaascapaciteit groter dan $600 \mathrm{ml}$ als pathologisch.

Fagerberg (1969) en Buck et al: (1976) vonden resp. bij 50 en $72 \%$ van de door hen onderzochte diabetici een blaascapaciteit groter dan $500 \mathrm{ml}$. Frimodt-Mgller (1976a) vond bij diabetici een gemiddelde blaascapaciteit van $913 \mathrm{ml}$ (SD $233 \mathrm{ml}$ ). Wij vonden bij 24\% van de diabetici een blaascapaciteit groter dan $600 \mathrm{ml}$. De blaascapaciteit werd door ons ook als abnormaal bevonden wanneer deze kleiner was dan $250 \mathrm{ml}$ (kenmerk van detrusorhyperreflexie). Wij vonden dit bij 14\% van de patienten.

Frimodt-Mgller (1976a) vond bij diabetici met een cystoneuropathie een eerste aandrang bij een vulling die varieerde van 400 tot $700 \mathrm{ml}$. Ellenberg en Weber (1967) en Howard (1982) vonden zelts een eerste aandrang bij een vulling boven de $1000 \mathrm{ml}$.

Wij vonden een eerste aandrang bij een vulling van 30 to $750 \mathrm{~m} /$ water en bij $25 \%$ van de patienten was deze waarde hoger dan $300 \mathrm{ml}$ water (onze grenswaarde). De eerste aandrang werd door ons ook als pathologisch beschouwd bij een vulling beneden de 50 $\mathrm{mil}$ water gevonden (kenmerk van detrusorhyperréflexie). "Wij wonden dift 'bil 2 pätientern $(2,5 \%)$.

Andersen en Bradley (1980) vonden door middel van cystometrisch anderzoek een detrusorhypo- of areflexie bij $43 \%$ en een detrusorhyperreflexie bij $23 \%$ van de door hen onderzochte diabetici. Wij vonden slechts bij $15(22 \%)$ van de 68 diabetici zonder infravesicale obstructie, het karakteristieke aspect van een hypotone curve en bij 11 patienten $(16 \%)$ het aspect van een hypertone curve.

Evenals Fagerberg (1969) en Frimodt-Mgller (1978) vonden ook wij geen verandering van de gemiddelde mictiedruk bij de door ons onderzochte diabetici. De maximale mictiedruk bij diabetici zonder infravesicale obstructie was bij de door ons onderzochte vrouwen lager dan bij de mannen.

Andersen en Bradley (1976) vonden een gemiddelde flow van $5,8 \mathrm{ml} / \mathrm{s}$ met waarden die varieerden van $2-11 \mathrm{ml} / \mathrm{s}$ bili 30 diabetici, en Frimodt-Mgller (1978) van 13,6 ml/s (SD 5,7 $\mathrm{m} / \mathrm{s}$ ) bij 44 diabetici met een cystoneuropathie. Wij vonden bij $97 \%$ van de de onderzoch. te diabetici een verminderde of normale flow. Onze gemiddelde flow $12,7 \mathrm{ml} / \mathrm{s}$ (SD 6,0 $\mathrm{m} / \mathrm{s}$ ) kamt overeen met de gemiddelde flow bepaald door Frimodt-Mgller (1978).

$\mathrm{De}$ door ons verrichte flowmetingen werden niet verricht als een apart onderzoek, maar in combinatie met een infravesicale drukmeting, waarbij éen of twee katheters in de urethra lagen. 


\section{EVALUATIE KLINISCH-NEUROFYSIOLOGISCH ONDERZOEK BIJ PATIENTEN-SUBGROEPEN OP BASIS VAN ANAMNESTISCHE EN URODYNAMISCHE CRITERIA EN VICE VERSA}

In dit hoofdstuk worden de resultaten van de neurofysiologische tests vergeleken met anamnestische en urodynamische gegevens.

De patienten worden verdeeld in subgroepen op basis van 8 anamnestische en 5 urologische criteria.

Nagegaan wordt of de TEP vaker gestoord is bili centrale laesies en de $\mathrm{H}$-reflex ( $\mathrm{H}-\mathrm{M}$ interval) vaker bij perifere laesies van het urogenitale systeem.

Op basis van afwijkende klinisch-neurofysiologissche bevindingen wordt een waarschijnlijke localisatie van de neurogene laesie vastgesteld.

Daar slechts bij 18 patienten reflexen werden geregistreerd uit de $\mathrm{m}$. bulbocavernosus worden deze gegevens niet bij deze analyse betrokken.

Voor de toetsing van het verschil van gemiddelden werd de Student-t test toegepast, waarbij niet aangenomen werd dat de variantie gelijk was voor de te vergelijken groepen. De P-waarden werden berekend uitgaande van een eenzijdige hypothese. 
7.1. LATENTIETIJDEN VAN REFLEXEN EN EVOKED POTENTIALS BIJ SUBGROEPEN VAN DIABETICI MET UROGENITALE KLACHTEN EN/OF UROLOGISCHE AFWIJKINGEN

7.1.1. LATENTIETIJDEN VAN REFLEXEN EN EVOKED POTENTIALS BIJ DIABETICI MET UROGENITALE KLACHTEN EN/OF UROLOGISCHE AFWIJKINGEN

In de tabellen $7.1 \mathrm{t} / \mathrm{m} 7.6$ worden deze gegevens vermeld.

\section{Tabel 7.1}

Resultaten neurofysiologische tests bij diabetici met zowel klachten als afwijkingen en bij de overige diabetici (Gemiddelden en standaarddeviaties in ms)

\begin{tabular}{|c|c|c|c|c|c|}
\hline \multirow[b]{2}{*}{ VAR m. sph. ani ext. } & & \multicolumn{2}{|c|}{ overige diabetici } & \multicolumn{2}{|c|}{$\begin{array}{l}\text { met klachten en } \\
\text { afwijkingen }\end{array}$} \\
\hline & $\begin{array}{l}\text { mannen } \\
\text { vrouwen }\end{array}$ & $\begin{array}{l}7 \\
3\end{array}$ & $\begin{array}{l}72,1(12,0) \\
71,7(8,5)\end{array}$ & $\begin{array}{l}26 \\
40\end{array}$ & $\begin{array}{l}74,5(16,0) \\
74,9(14,2)\end{array}$ \\
\hline BCA I m. sph. ani ext. & $\begin{array}{l}\text { mannen } \\
\text { vrouwen }\end{array}$ & $\begin{array}{l}6 \\
3\end{array}$ & $\begin{array}{l}37,5(10,1) \\
37,3(5,0)\end{array}$ & $\begin{array}{l}26 \\
42\end{array}$ & $\begin{array}{l}37,3(6,4) \\
39,2(12,6)\end{array}$ \\
\hline BCR II m. sph. ani ext. & $\begin{array}{l}\text { mannen } \\
\text { vrouwen }\end{array}$ & $\begin{array}{l}6 \\
3\end{array}$ & $\begin{array}{l}74,8(14,1) \\
75,7(6,4)\end{array}$ & $\begin{array}{l}25 \\
41\end{array}$ & $\begin{array}{l}78,1(9,7) \\
79,6(18,1)\end{array}$ \\
\hline PEP & $\begin{array}{l}\text { mannen } \\
\text { vrouwen }\end{array}$ & $\begin{array}{l}7 \\
3\end{array}$ & $\begin{array}{l}44,9(6,3) \\
38,7(2,1)\end{array}$ & $\begin{array}{l}25 \\
42\end{array}$ & $\begin{array}{l}45,1(3,0) \\
43,4(7,1)\end{array}$ \\
\hline PHEP & $\begin{array}{l}\text { mannen } \\
\text { vrouwen }\end{array}$ & $\begin{array}{l}5 \\
2\end{array}$ & $\begin{array}{l}57,8(8,0) \\
60,5(-)\end{array}$ & $\begin{array}{l}13 \\
18\end{array}$ & $\begin{array}{l}69,5(15,0)^{*} \\
78,5(24,5)^{*}\end{array}$ \\
\hline
\end{tabular}




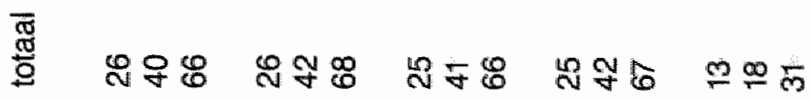

동

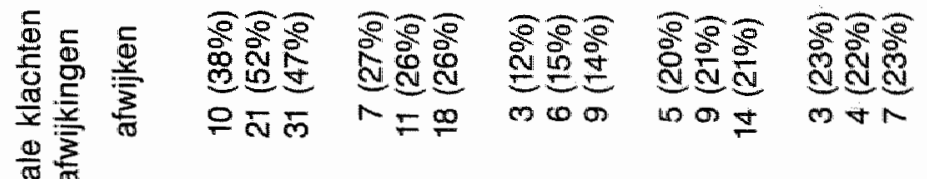
政

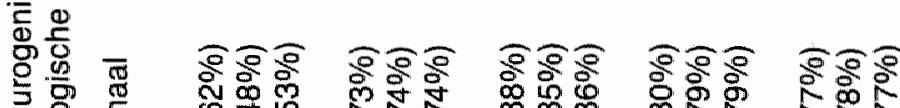

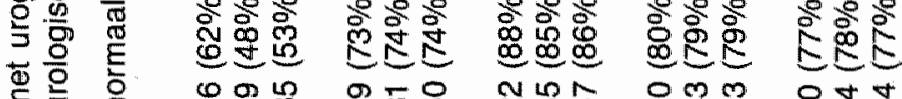

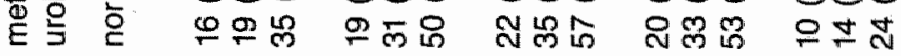

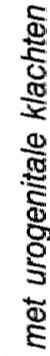

ฐूँ NmO

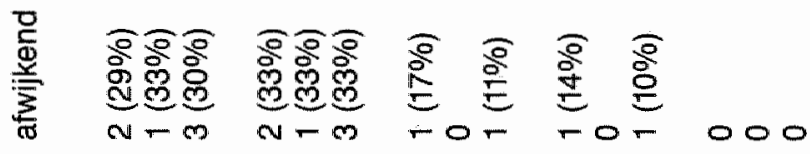
默 政

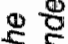

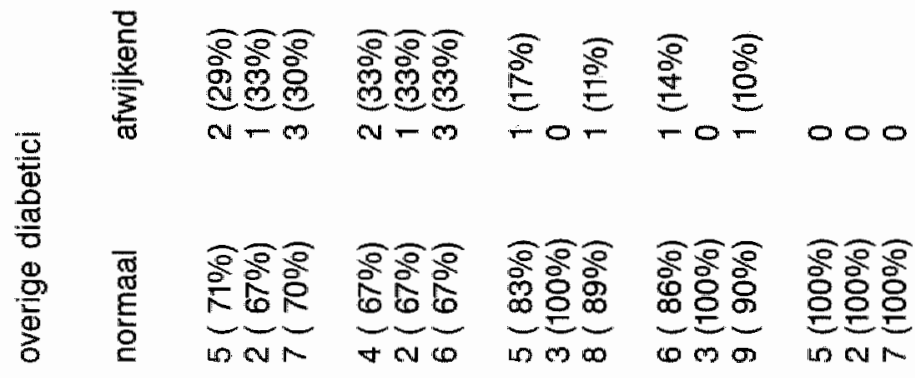

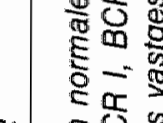


Resultaten neurofysiologische tesits bil diabetici met klachten zonder urologische afwijkingen en bil de overige diabetici (Gemiddelden en standaarddeviaties in $\mathrm{ms}$ )

$$
\begin{aligned}
& \text { overige diabetici met klachten zonder } \\
& \text { urologische afwijkingen }
\end{aligned}
$$

\begin{tabular}{llllll} 
& \multicolumn{3}{c}{ N } & N \\
VAR m. sph. ani ext. & mannen & 7 & $72,1(12,0)$ & 25 & $74,4(44,0)$ \\
& vrouwen & 5 & $75,4(15,6)$ & 31 & $73,4(12,0)$ \\
BCR I m. sph. ani ext. & mannen & 6 & $37,5(10,1)$ & 25 & $37,8(6,0)$ \\
& vrouwen & 5 & $38,6(4,1)$ & 33 & $39,1(13,4)$ \\
BCR II m. sph. ani ext. & mannen & 6 & $74,8(14,1)$ & 24 & $78,4(9,8)$ \\
& vrouwen & 5 & $82,4(11,3)$ & 32 & $79,8(19,5)$ \\
PEP & mannen & 7 & $44,9(6,3)$ & 24 & $45,2(3,0)$ \\
& vrouwen & 5 & $38,4(1,7)$ & 33 & $43,5(6,7)^{\star}$ \\
PHEP & mannen & 5 & $57,8(8,0)$ & 12 & $68,6(15,3)^{*}$ \\
& vrouwen & 3 & $88,7(49,0)$ & 14 & $70,9(13,2)$
\end{tabular}

${ }^{*} \mathrm{P}<0,05$ 


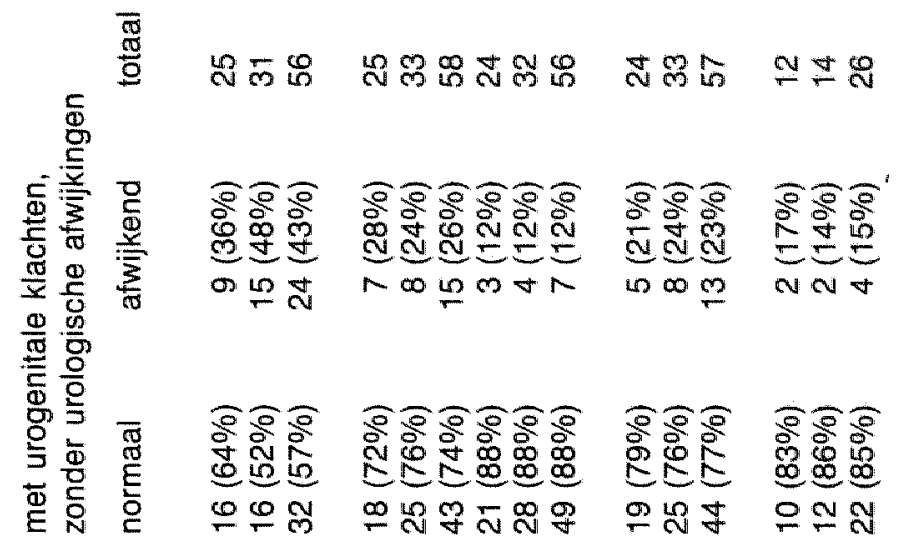

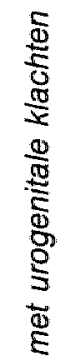

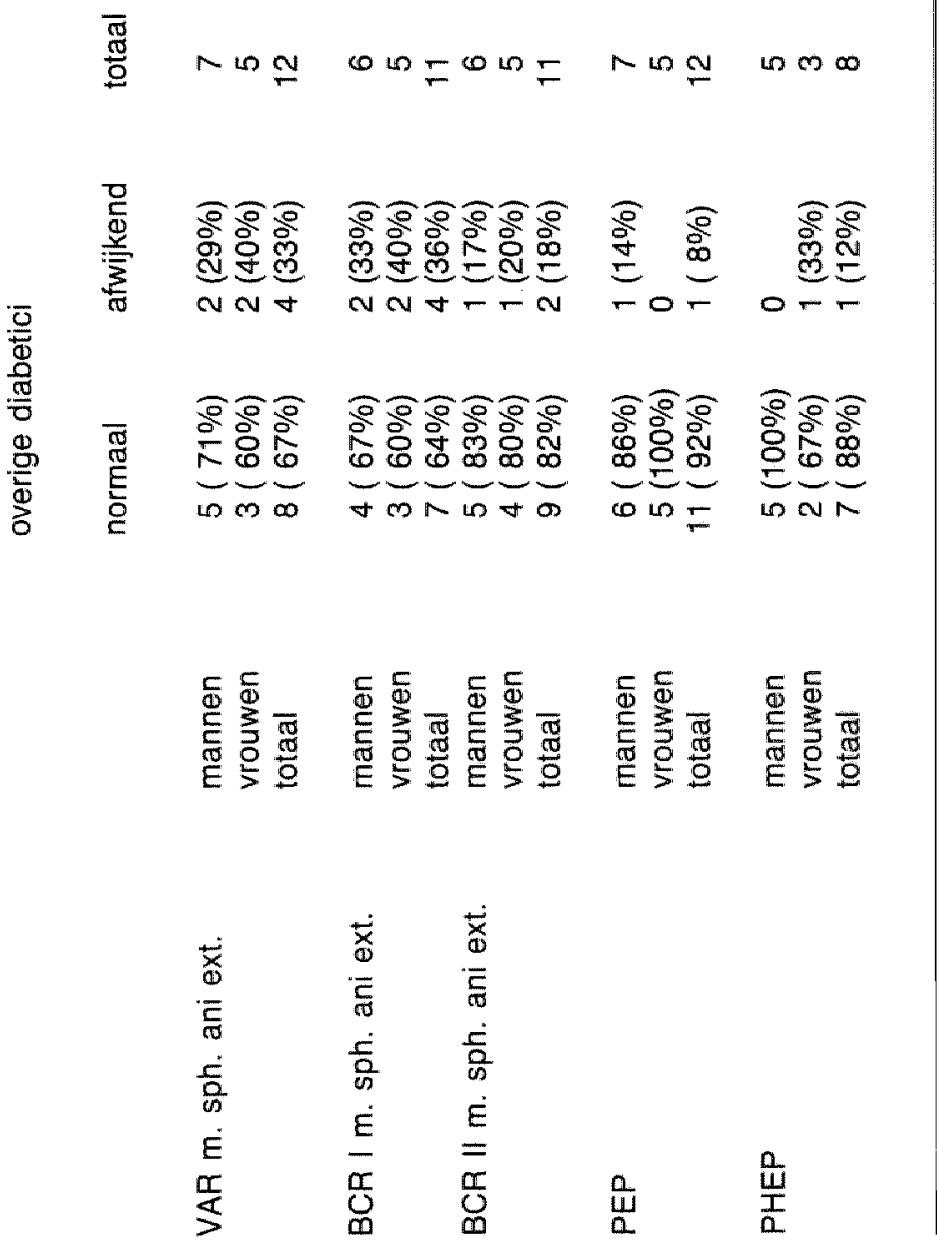


Resultaten neurofysiologische tests bij diabetici met urologische afwijkingen zonder klachten en bil de overige diabetici

(Gemiddelden en standaarddeviaties in $\mathrm{ms}$ )

$$
\begin{array}{ll}
\text { overige diabetici } & \begin{array}{l}
\text { met klachten zonder } \\
\text { urologische afwijkingen }
\end{array} \\
N & N
\end{array}
$$

VAR m. sph. ani ext. mannen $26 \quad 72,3(15,1) \quad 8 \quad 78,1(14,5)$

vrouwen $\quad \begin{array}{llll}73,0 & (6,9) \quad 37 & 75,0 & (14,6)\end{array}$

BCR I m. sph. ani ext. mannen $25 \quad 36,5(6,3) \quad 8 \quad 39,5(8,7)$

vrouwen $8 \quad 42,1(12,3) \quad 38 \quad 38,6(12,2)$

BCR II m. sph. ani ext. mannen $24 \quad 76,3(10,7) \quad 8 \quad 80,6(9,0)$

PEP

vrouwen $\quad 7 \quad 77,0(5,6) \quad 38 \quad 80,0(18,8)$

mannen $26 \quad 45,0(4,4) \quad 7 \quad 46,1(2,6)$

vrouwen $8 \quad 42,1(5,6) \quad 38 \quad 43,3(7,2)$

PHEP mannen $15 \quad 66,5(14,2) \quad 4 \quad 68,5(16,0)$

vrouwen $3 \quad 66,0(10,5) \quad 17 \quad 78,6(25,2)$

Er werden geen significante verschillen tussen de gemiddelden gevonden 


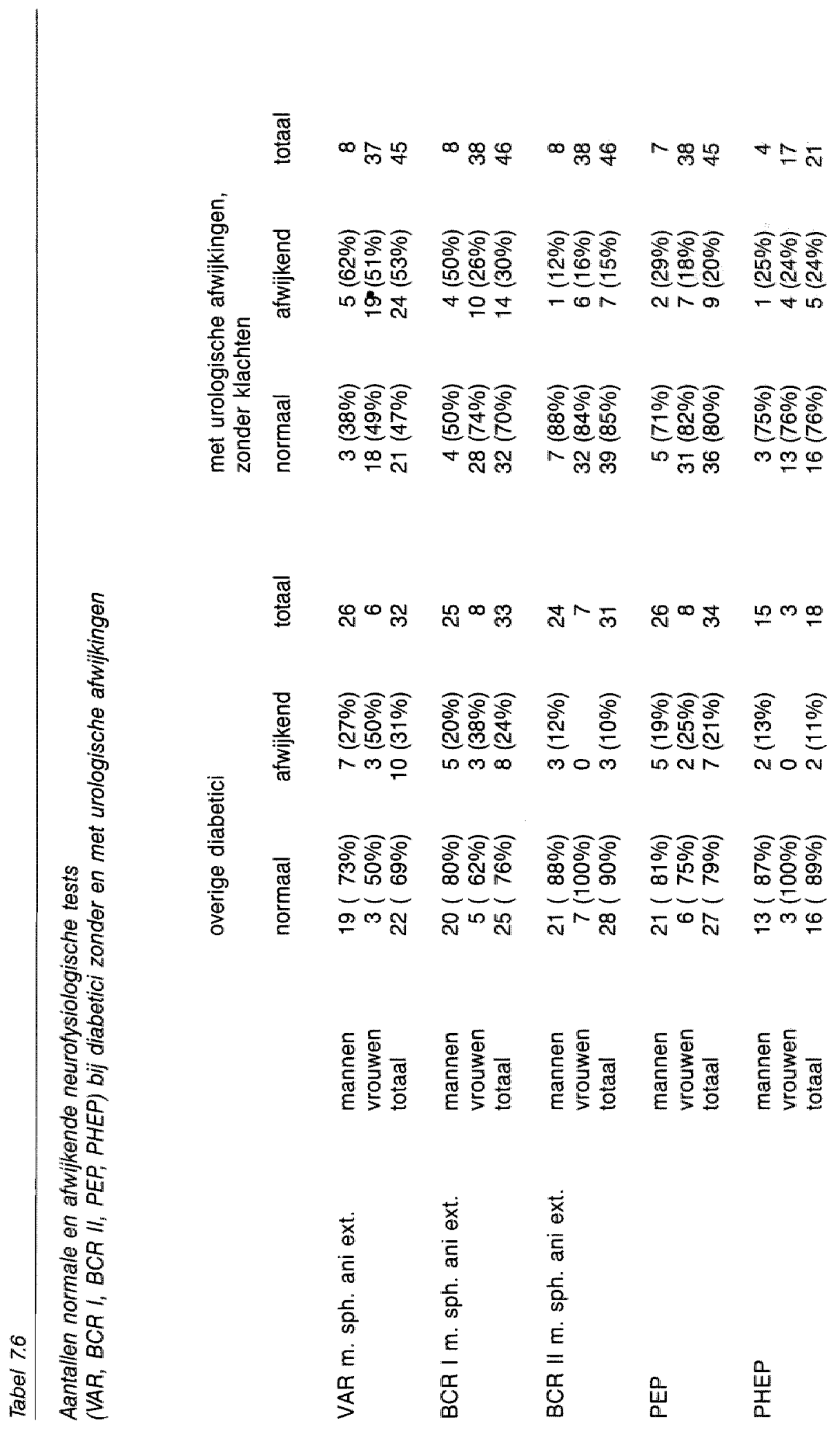




\subsubsection{LATENTIETIJDEN VAN REFLEXEN EN EVOKED POTENTIALS BIJ PATIENTENSUBGROEPEN OP BASIS VAN GESPECIFICEERDE UROGENITALE KLACHTEN EN UROLOGISCHE AFWIJKINGEN}

De patienten worden verdeeld in subgroepen op basis van 8 anamnestische en 5 urologische criteria.

De 8 subgroepen op basis van anamnese zijn:

1. incontinentie (stress, urge)

2. mictiedrang

3. passagegevoel bij de mictie

4. blaasledigingsgevoel

5. libido

6. erectie

7. ejaculatie

8. orgasme

De 5 subgroepen op basis van urologische afwijkingen zijn:

1. detrusorgedrag

2. residu

3. blaascapaciteit

4. eerste aandrang

5. maximale mictiedruk

Voor latentietijden van reflexen en evoked potentials (gemiddelden en standaarddeviaties) van de verschillende subgroepen, zie appendix 7.1.2. (tabellen $7.7 \mathrm{t} / \mathrm{m}$ 7.31).

7.1.3. LATENTIETIJDEN VAN TEP EN H-REFLEX (H-M INTERVAL) BIJ DIABETICI IN RELATIE MET DE OVERIGE KLINISCH-NEUROFYSIOLOGISCHE AFWIJKINGEN

In tabel $7.32 \mathrm{t} / \mathrm{m} 7.36$ worden deze gegevens vermeld.

Tabel 7.32

Aantallen normale en verlengde latentietijden $H$-reflex ( $H-M$ interval) zonder en met afwijkende TEP

zonder afwijkende TEP

H-reflex

Mannen

Vrouwen

Totaal normaal verlengd totaal

met afwijkende TEP

normaal verlengd totaal

$3(25 \%) \quad 9(75 \%) \quad 12$

$4(15 \%) \quad 26(85 \%) \quad 30$

$7(17 \%) \quad 35(83 \%) \quad 42$ 
Aantallen normale en verlengde latentietijden H-reflex (H-M interval) zonder afwijkende VAR en BCR I en met een afwijkende WAR of BCR I

\section{zonder afwijkende VAR en BCR I}

H-reflex

Mannen

Vrouwen

Totaal

$\begin{array}{rrl}\text { normaal } & \text { verlengd } & \text { totaa } \\ 7(50 \%) & 7(50 \%) & 14 \\ 12(80 \%) & 3(20 \%) & 15 \\ 19(66 \%) & 10(34 \%) & 29\end{array}$

met afwijkende VAR of BCR I

\section{Tabel 7.34}

Latentietijden van TEP en H-M interval bij diabetici zonder en met afwijkingen (VAR, BCR I, BCR II, PEP en/of PHEP) (Gemiddelden en standaarddeviaties in ms)

\begin{tabular}{|c|c|c|c|c|c|}
\hline & & & zonder & & met \\
\hline & & $N$ & & $\mathbb{N}$ & \\
\hline TEP & mannen & $\begin{array}{r}10 \\
6\end{array}$ & $\begin{array}{l}47,5(5,3) \\
40,5(2,6)\end{array}$ & $\begin{array}{l}10 \\
27\end{array}$ & $\begin{array}{l}52,4(9,6) \\
51,3(7,3)\end{array}$ \\
\hline $\mathrm{H}-\mathrm{M}$ interval & $\begin{array}{l}\text { mannen } \\
\text { vrouwen }\end{array}$ & $\begin{array}{r}10 \\
6\end{array}$ & $\begin{array}{l}29,9(4,5) \\
26,0(2,8)\end{array}$ & $\begin{array}{l}17 \\
30\end{array}$ & $\begin{array}{l}32,9(5,8) \\
31,4(4,2)\end{array}$ * \\
\hline
\end{tabular}

Tabel 7.35

Latentietijden van TEP en H-M interval bil diabetici zonder afwijkingen (VAR, BCR I, BCR II, PEP, PHEP) en met een afwijkende VAR en/of BCR I

(Gemiddelden en standaarddeviaties in $\mathrm{ms}$ )

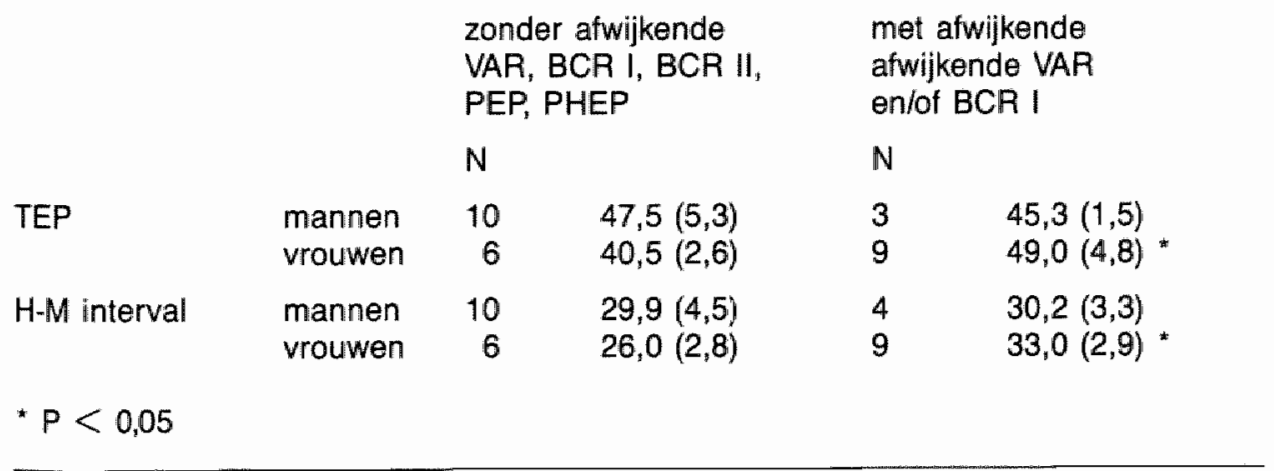


Latentiefijden van TEP en H-M interval bij diabetici zonder afwijkingen (VAR, $B C A$ I, BCA $I_{1}$ PEP, PHEP) en met een afwijkende PEP en/of PHEP

(Gemiddelden en standaarddewiaties in $\mathrm{ms}$ )

\begin{tabular}{|c|c|c|c|c|c|}
\hline & & $\begin{array}{l}\text { ZOn } \\
\text { WAF } \\
\text { PEF }\end{array}$ & $\begin{array}{l}\text { twijkende } \\
\mathrm{R} \mathrm{I}, \mathrm{BCR} I 1, \\
\mathbb{E P}\end{array}$ & & $\begin{array}{l}\text { jkende } \\
\text { SHEP }\end{array}$ \\
\hline & & $\mathbb{M}$ & & $N$ & \\
\hline TEP & $\begin{array}{l}\text { mannen } \\
\text { vrouwen }\end{array}$ & $\begin{array}{r}10 \\
6\end{array}$ & $\begin{array}{l}47,5(5,3) \\
40,5(2,6)\end{array}$ & $\begin{array}{l}2 \\
3\end{array}$ & $\begin{array}{l}46,5 \\
53,7(11,4)\end{array}$ \\
\hline H-M interval & $\begin{array}{l}\text { mannen } \\
\text { vrouwen }\end{array}$ & $\begin{array}{r}10 \\
6\end{array}$ & $\begin{array}{l}29,9(4,5) \\
26,0(2,8)\end{array}$ & $\begin{array}{l}3 \\
3\end{array}$ & $\begin{array}{l}33,0(6,6) \\
27,3(0,6)\end{array}$ \\
\hline
\end{tabular}

Er werden geen significante verschillen tussen de gemiddelden gevonden

\subsubsection{CONCLUSIES}

Urogenitale klachten gaven bij de onderzochte diabetici weinig informatie over de te verwachten klinisch-neurofysiologische afwijkingen.

Alleen bij patienten zonder mictiedrang werd een significante samenhang gevonden met afwijkende neurofysiologische tests zoals gezien bij een perifere laesie van het urogenitale systeem.

Urologische afwijkingen gaven bij de onderzochte diabetici eveneens weinig informatie over de te verwachten klinisch-neurofysiologische afwijkingen.

Alleen bij patienten met een pathologisch residu en een maximale mictiedruk $<25 \mathrm{~cm}$ werd een significante samenhang gevonden met afwijkende neurofysiologische tests zoals gezien bij een perifere laesie van het urogenitale systeem.

De PEP was significant langer bij urologische afwijkingen, volgens de literatuur passend bij een perifere stoornis zoals hypotoon detrusorgedrag, blaascapaciteit $>600 \mathrm{ml}$ en eerste aandrang bij meer dan $300 \mathrm{ml}$ water.

Bij vrouwelijke diabetici met afwijkingen (VAR, BCR I, BCR II, PEP en/of PHEP) waren de TEP en H-reflex (H-M interval) significant vaker gestoord dan bij de groep zonder bovengenoemde elektrofysiologische afwijkingen.

Bij de vrouwelijke diabetici met een afwijkende VAR en/of BCR I en een intacte PEP en/of PHEP waren de $\mathrm{H}$-reflex ( $\mathrm{H}-\mathrm{M}$ interval) en de TEP significant vaker gestoord. Bij de mannelijke diabetici was er geen significante relatie.

Een afwijkende VAR en/of BCR I bij een normale PEP en/of PHEP werd beschouwd als aanwijzing voor een stoornis van alleen de perifere innervatie van het urogenitale systeem.

Bij de mannelijke en vrouwelijke diabetici met een afwijkende PEP en/of PHEP en een intacte VAR en/of BCR I waren de TEP en de H-reflex (H-M interval) niet significant vaker gestoord.

Een afwijkende PEP en/of PHEP bij een normale VAR en/of BCR I werd beschouwd als 
aanwijzing voor een stoornis van alleen de centrale innervatie van het urogenitale systeem.

$83 \%$ Van de onderzochte diabetici met een verlengde latentielijd van de TEP hadden ook een werlengde latentietijd van de $\mathrm{H}$-reflex ( $\mathrm{H}-\mathrm{M}$ interval).

$21 \%$ Van de onderzochte diabetici met een normale latentietijd van de TEP hadden een verlengde latentietijd van de $\mathrm{H}$-reflex ( $\mathrm{H}-\mathrm{M}$ interval).

Een verlengde latentietijd van de $\mathrm{H}$-reflex ( $\mathrm{H}-\mathrm{M}$ interval) werd gevonden bij $73 \%$ van de diabetici met een afwijkende VAR en/of BCA I en bij 34\% van de patienten zonder afwijkende VAR en/of BCR I.

\subsection{AANTALLEN NORMALE EN AFWIJKENDE NEUROFYSIOLOGISCHE TESTS VOLGENS HET LOCALISATIEMODEL BIJ PATIENTENSUBGROEPEN OP BASIS VAN UROGENITALE KLACHTEN EN UROLOGISCHE AFWIJKINGEN}

Bii 75 diabetici ( 35 wel en 40 miet insuline athankelijk) wordt door middel van het combineren van reflexen en evoked potentials (VAR, BCR I en PEP) tesamen met het elektromyografisch onderzoek van de $\mathrm{m}$. sphincter ani externus, getracht de waarschijnlijke localisatie van de laesie en de frequentie van voorkomen te bepalen (zie hoofdstuk 4). Tevens wordt de frequentie van voorkomen van spontane spiervezelpotentialen tesamen met de bovengenoemde reflexen en evoked potentials bij deze groep diabetici onderzocht.

De PHEP werd pas in een latere fase bil het onderzoek betrokken. Deze wordt daarom slechts geregistreerd bij 38 van de 75 diabetici ( 13 well en 25 niet insuline afhankelijk).

De aantallen normale en afwijkende neurofysiologische tests alleen en in combinatie worden nagegaan bij diabetici zonder en met urogenitale klachten en/of urologische afwijkingen.

Vervolgens worden de diabetici verdeeld in subgroepen op basis van 8 anamnestische en 5 urologische afwijkingen en worden opnieuw de aantallen normale en afwijkende neurofysiologische tests alleen en in combinatie nagegaan.

Vooral aan het detrusorgedrag wordt veel aandacht besteed.

Daar de BCR || steeds afwijkend was in combinatie met de BCR I wordt deze buiten beschouwing gelaten. 


\subsubsection{WAARSCHIJNLUIKE LOCALISATIES VAN VERSCHILLENDE LAESIES BIJ PATIENTEN MET DIABETES MELLITUS}

Voor een overzicht van deze gegevens zie tabellen $7.37 \mathrm{t} / \mathrm{m} 7.43$.

Tabel 7.37

Aantallen normale en afwilkende neurofysiologische tests (VAR, BCR I, PEP) alleen en in combinatie bij 75 patienten met diabetes mellitus

\begin{tabular}{lllllll}
$\begin{array}{l}\text { insuline afhankelijke } \\
\text { diabetici }\end{array}$ & \multicolumn{5}{c}{$\begin{array}{l}\text { niet insuline afhankelijke } \\
\text { diabetici }\end{array}$} \\
$\begin{array}{l}\text { mannen } \\
N=15\end{array}$ & $\begin{array}{l}\mathrm{N}=20 \\
\mathrm{~N}=\mathrm{N}=35\end{array}$ & $\mathrm{~N}=17$ & $\mathrm{~N}=23$ & $\mathrm{~N}=40$ \\
$3(20 \%)$ & $4(20 \%)$ & $7(20 \%)$ & $11(65 \%)$ & $10(44 \%)$ & $21(52 \%)$ \\
$6(40 \%)$ & $7(35 \%)$ & $13(37 \%)$ & $1(6 \%)$ & $5(22 \%)$ & $6(15 \%)$ \\
$2(13 \%)$ & $2(10 \%)$ & $4(11 \%)$ & $1(6 \%)$ & $1(40 \%)$ & $2(5 \%)$ \\
- & $2(10 \%)$ & $2(6 \%)$ & - & $1(4 \%)$ & $1(2 \%)$ \\
$1(7 \%)$ & - & $1(3 \%)$ & $2(12 \%)$ & $1(4 \%)$ & $3(8 \%)$ \\
$2(13 \%)$ & $4(20 \%)$ & $6(17 \%)$ & $2(12 \%)$ & $2(9 \%)$ & $4(10 \%)$ \\
- & $1(5 \%)$ & $1(3 \%)$ & - & $3(13 \%)$ & $3(8 \%)$ \\
$1(7 \%)$ & - & $1(3 \%)$ & - & - & -
\end{tabular}

Tabel 7.38

Waarschijnijke localisatie van de laesie(s) op basis van afwijkende neurofysiologische tests bif diabetici

1. Geen afwijkingen

2. VAR alleen

$=\mathrm{n}$. pelvicus (perifeer sensibel).

3. PEP alleen

$=$ achterstreng/lemniscus systeem.

4. BCR | alleen

$=\mathrm{n}$. pudendus (motorisch).

5. $B C R 1+$ PEP

$=\mathrm{n}$. pudendus (sensibel).

6. $B C R \mid+V A R$

$=\mathrm{n}$. pudendus (motorisch).

7. $P E P+V A R$

$=\mathrm{n}_{\text {n }}$ pelvicus (perifeer sensibel), achterstreng/lemniscus medialis.

8. $P E P+V A R+B C R \|=n$. pudendus (sensibel),

n. pudendus (motorisch),

n. pelvicus (perifeer sensibel). 
Waarschijnlijke localisatie van de verschillende laesies bif 35 insuline en 40 miet insuline athankelijke diabetici op basis van 3 neurofysiologische tests (VAR, BCR I, PEP)

\begin{tabular}{|c|c|c|c|c|c|c|}
\hline & \multicolumn{3}{|c|}{$\begin{array}{l}\text { insuline afhankelijkke } \\
\text { diabetici }\end{array}$} & \multicolumn{3}{|c|}{$\begin{array}{l}\text { niet insuline afhankelijke } \\
\text { diabeticl }\end{array}$} \\
\hline & $\begin{array}{l}\text { mannen } \\
N=15\end{array}$ & $\begin{array}{l}\text { Vrouwen } \\
\mathrm{N}=20\end{array}$ & $\begin{array}{l}\text { totaal } \\
N=35\end{array}$ & $\begin{array}{l}\text { mannen } \\
N=17\end{array}$ & $\begin{array}{l}\text { Wrouwen } \\
N=23\end{array}$ & $\begin{array}{l}\text { totaal } \\
N=40\end{array}$ \\
\hline $\begin{array}{l}\text { geen afwijkingen } \\
\text { n. pelvicus (perifeer }\end{array}$ & $3(20 \%)$ & $4(20 \%)$ & $7(20 \%)$ & $11(65 \%)$ & $10(44 \%)$ & $21(52 \%)$ \\
\hline $\begin{array}{l}\text { sensibel) } \\
\text { n. pudendus }\end{array}$ & $7(47 \%)$ & $8(40 \%)$ & $15(43 \%)$ & $1(6 \%)$ & $8(35 \%)$ & $9(23 \%)$ \\
\hline $\begin{array}{l}\text { (motorisch) } \\
\text { n. pudendus }\end{array}$ & $3(20 \%)$ & $6(30 \%)$ & $9(26 \%)$ & $2(12 \%)$ & $3(13 \%)$ & $5(120 \%)$ \\
\hline $\begin{array}{l}\text { ensibel) } \\
\text { idendus vezels }\end{array}$ & $2(13 \%)$ & - & $2(6 \%)$ & $1(6 \%)$ & $1(4 \%)$ & $2(5 \%)$ \\
\hline ruggemerg & $2(13 \%)$ & $3(15 \%)$ & $5(14 \%)$ & $1(6 \%)$ & $4(170 \%)$ & $5(12 \%)$ \\
\hline
\end{tabular}

Bij 6 patienten $(8 \%)$, 2 wel en 4 niet insuline afhankelijk, werd door middel van elektromyografisch onderzoek van de $\mathrm{m}$. sphincter ani externus een axonale laesie van de motorische vezels van de $n$. pudendus gediagnostiseerd, bij een normale latentietijd van de motorische vezels van de $n$. pudendus.

Na toevoeging van het aantal patienten met een afwijkend ellektromyografisch onderzoek van de $\mathrm{m}$. sphincter ani externus neemt de frequentie van laesies van de motorische vezels van de $\mathrm{n}$. pudendus toe van 19 tot $27 \%$.

Bij de insuline afhankelijke diabetici is er een toename tot $31 \%$ en bij de niet insuline athankelijke tot $23 \%$ (zie tabel 7.40 ).

\section{Tabel 7.40}

Waarschijinjke localisatie van de verschillende laesies bij 35 insuline en 40 niat insuline athankelijke diabetici op basis van 3 neurofysiologische tests (VAR, BCR I, PEP) en EMG van de m. sphincter ani extermus

\begin{tabular}{|c|c|c|c|}
\hline & $\begin{array}{l}\text { insuline } \\
\text { afhankelijk } \\
\mathrm{N}=35\end{array}$ & $\begin{array}{l}\text { niet insuline } \\
\text { afhankelijk } \\
\mathrm{N}=40\end{array}$ & $\begin{array}{l}\text { totaal } \\
N=75\end{array}$ \\
\hline $\begin{array}{l}\text { geen afwijkingen } \\
\text { n. pelvicus }\end{array}$ & $7(20 \%)$ & $21(52 \%)$ & $28(37 \%)$ \\
\hline $\begin{array}{l}\text { (perifeer sensibel) } \\
\text { n. pudendus }\end{array}$ & $15(43 \%)$ & $9(23 \%)$ & $24(32 \%)$ \\
\hline $\begin{array}{l}\text { (motorisch) } \\
n \text {. pudendus }\end{array}$ & $11(31 \%)$ & $9(23 \%)$ & $20(27 \%)$ \\
\hline $\begin{array}{l}\text { (sensibel) } \\
\text { pudenduls vezels in }\end{array}$ & $2(6 \%)$ & $2(5 \%)$ & $4(5 \%)$ \\
\hline ruggemerg & $5(14 \%)$ & $5(12 \%)$ & $10(13 \%)$ \\
\hline
\end{tabular}


Aantallen normale en afwijkende neurofysiologische tests (VAR, BCR I, PEP, PHEP) alleen en in combinatie bif 38 patienten met diabetes mellitus

\begin{tabular}{|c|c|c|c|c|c|}
\hline $\begin{array}{l}\text { insuline } \\
\text { diabetici }\end{array}$ & ankelijke & & $\begin{array}{l}\text { niet insul } \\
\text { diabetici }\end{array}$ & e affhank & \\
\hline $\begin{array}{l}\text { mannen } \\
N=6\end{array}$ & $\begin{array}{l}\text { vrouwen } \\
N=7\end{array}$ & $\begin{array}{l}\text { totaal } \\
N=13\end{array}$ & $\begin{array}{l}\text { mannen } \\
\mathrm{N}=12\end{array}$ & $\begin{array}{l}\text { vrouwen } \\
N=13\end{array}$ & \\
\hline
\end{tabular}

1. geen afwijkingen $\quad 2(33 \%) \quad 1(14 \%) \quad 3(23 \%) \quad 8(67 \%) \quad 5(38 \%) \quad 13(52 \%)$

2. VAR alleen $\quad 2(33 \%) \quad 3(43 \%) \quad 5(38 \%) \quad 1(8 \%) \quad 3(23 \%) \quad 4(16 \%)$

3. PEP alleen - - $\quad$ - $\quad 1 \quad 1(8 \%) \quad 1(8 \%) \quad 2(8 \%)$

4. BCR I alleen

5. PHEP alleen

6. PEP + VAR

$2(29 \%)$

$2(15 \%$

$1(8 \%)$

$1(4 \%)$

7. BCR + VAR -

8. PHEP + VAR -

9. $\mathrm{PEP}+\mathrm{BCR} I-$

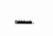

10. PEP + PHEP

$1(17 \%)$

$1(14 \%)$

$2(15 \%)-$

$1(8 \%) \quad 1(8 \%) \quad 2(8 \%)$

11. BCR I + PHEP -

12. PEP * BCR I

$$
+ \text { VAR }
$$

13. VAR + PEP
+ PHEP
$1(17 \%)$
$1(8 \%)-$

14. VAR + BCR I

+ PHEP

15. PEP + BCR

+ PHEP

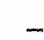

16. PEP + BCA I
+ PHEP
+ VAR 
Waarschinnijke localisatie van de laesies op basis van atwijkende neurofysiologische tests

1. geen afwijkingen.

2. VAR alleen

3. PEP alleen

4. BCA $\|$ alleen

5. PHEP alleen

6. PEP + VAR

7. $\mathrm{BCR} I+$ VAR

8. PHEP + VAR

9. PEP + BCR I

10. PEP + PHEP

11. BCR I + PHEP

12. $\mathrm{PEP}+\mathrm{BCR} \|+\mathrm{VAR}$

13. $V A R+P E P+P H E P$

14. VAR + BCR I + PHEP

15. $P E P+B C R I+P H E P$

16. $\mathrm{PEP}+\mathrm{BCR}$ I + VAR + PHEP =n. pudendus (sensibel, motorisch) en eventueel pudendus vezels in ruggemerg, n. pellvicus (perifeer sensibel) en eventueel pelvicus vezels in ruggemerg hypogastricus vezels in ruggemerg en/of $n$. hypogastricus (perifeer sensibel) 
Waarschinhlike localisatie van de verschillende laesies bij 13 insuline en 25 niet insuline athankelijke diabetici, op basis van 4 neurofysiologische tests (VAR, BCRI, PEP, PHEP)

\begin{tabular}{|c|c|c|c|c|c|c|}
\hline & \multicolumn{3}{|c|}{$\begin{array}{l}\text { insuline afhankelijke } \\
\text { diabetic: }\end{array}$} & \multicolumn{3}{|c|}{$\begin{array}{l}\text { niet insuline afhankelijke } \\
\text { diabetici }\end{array}$} \\
\hline & $\begin{array}{l}\text { mannen } \\
\mathbb{N}=6\end{array}$ & $\begin{array}{l}\text { vrouwen } \\
N=7\end{array}$ & $\begin{array}{l}\text { totaal } \\
N=13\end{array}$ & $\begin{array}{l}\text { mannen } \\
\mathrm{N}=12\end{array}$ & $\begin{array}{l}\text { vrouwen } \\
N=13\end{array}$ & $\begin{array}{l}\text { totaal } \\
N=25\end{array}$ \\
\hline $\begin{array}{l}\text { geen afwijkingen } \\
\text { n. pelvicus }\end{array}$ & $2(33 \%)$ & $1(14 \%)$ & $3(23 \%)$ & $8(67 \%)$ & $5(38 \%)$ & $13(52 \%)$ \\
\hline $\begin{array}{l}\text { (perifeer sensibel) } \\
\text { n. pudendus }\end{array}$ & $3(50 \%)$ & $5(71 \%)$ & $8(62 \%)$ & $2(17 \%)$ & $3(23 \%)$ & $5(20 \%)$ \\
\hline $\begin{array}{l}\text { (motorisch) } \\
\text { n. pudendus }\end{array}$ & - & - & - & - & $2(15 \%)$ & $2(8 \%)$ \\
\hline $\begin{array}{l}\text { (sensibel) } \\
\text { pudendus vezels }\end{array}$ & - & - & - & $1(8 \%)$ & $2(15 \%)$ & $3(12 \%)$ \\
\hline $\begin{array}{l}\text { in ruggemerg } \\
\text { hypogastricus } \\
\text { wezels in } \\
\text { ruggemerg en/of } \\
\text { n. hypogastricus }\end{array}$ & $2(33 \%)$ & $3(43 \%)$ & $5(38 \%)$ & $2(17 \%)$ & $1(8 \%)$ & $3(12 \%)$ \\
\hline $\begin{array}{l}\text { (perifeer sensibel) } \\
\text { pelvicus vezels }\end{array}$ & $2(33 \%)$ & $1(1.4 \%)$ & $3(23 \%)$ & - & $2(15 \%)$ & $2(8 \%)$ \\
\hline in ruggemerg & $1(17 \%)$ & $1(14 \%)$ & $2(15 \%)$ & - & $2(15 \%)$ & $2(8 \%)$ \\
\hline
\end{tabular}

Bij 3 niet insuline afhankelijke diabetici $(8 \%)$ werd door middel van elektromyografisch onderzoek van de $\mathrm{m}$. sphincter ani externus een axonale laesie van de motorische vezels van de $n$. pudendus gediagnostiseerd, bij een normale latentietijd van de $n$. pudendus. Een laesie van de centrale pelvicus vezels ging altijd samen met een laesie van de $n$. hypogastricus (centraal eniof perifeer) 
7.2.2. AANTALLEN NORMALE EN AFWIJKENDE NEUROFYSIOLOGISCHE TESTS (NAR, BCR I, PEP) AFZONDERL_IJK EN IN COMBINATIE BIJ DIABETICI MET UROGENITALE KLACHTEN EN/OF UROLOGISCHE AFWIJKINGEN

\section{Tabel 7.44}

Aantallen normale en afwijkende neurofysiologische tests (VAR, BCR I, PEP) alleen en in combinatie bij 74 mannelijke en vrouwelijke diabetici zonder en met urogenitale klachten en tevens vastgestelde urologische afwijkingen

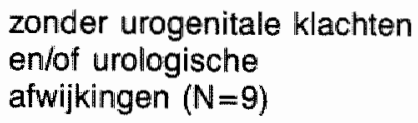

1. Geen afwijkingen $3(50 \%) \quad 2(67 \%) \quad 5(56 \%)$

2. VAR alleen

3. PEP alleen

4. BCR I alleen

5. $\mathrm{BCR} I+\mathrm{PEP}$

6. BCR I + VAR

7. PEP + VAR

8. PEP + VAR

+ BCR \|
$1(17 \%) \quad-$

$1(11 \%)$
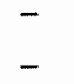

$1(17 \%) \quad-$

$1(17 \%) \quad 1(33 \%)$

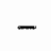

$-$ met urogenitale klachten en/of urologische afwijkingen ( $\mathrm{N}=65$ )

mannen vrouwen totaal $11(44 \%) \quad 12(30 \%) \quad 23(35 \%)$ $6(24 \%) \quad 12(30 \%) \quad 18(28 \%)$ $2(8 \%) \quad 3(8 \%) \quad 5(8 \%)$ - $3(8 \%) \quad 3(5 \%)$ $2(8 \%) \quad 1(2 \%) \quad 3(5 \%)$ $3(12 \%) \quad 5(12 \%) \quad 8(12 \%)$ $-\quad 4(10 \%) 4(6 \%)$

$1(4 \%)-$ $1(2 \%)$

Tabel 7.45

Aantallen normale en afwijkende neurofysiologische tests (VAR, BCR I, PEP) alleen en in combinatie bij 66 mannelijke en vrouwelijke diabetici zonder en met urogenitale klachten maar geen abjectiveerbare urolagische afwijkingen

\section{zonder \\ urogenitale klachten $(\mathbb{N}=11)$}

mannen vrouwen totaal met urogenitale klachten $(\mathrm{N}=55)$ mannen vrouwen totaal

1. Geen afwijkingen $3(50 \%) \quad 2(40 \%) \quad 5(46 \%) \quad 11(46 \%) \quad 10(32 \%) 21(38 \%)$

2. VAR alleen

$1(17 \%) \quad 1(20 \%) \quad 2(18 \%)$

$5(21 \%) \quad 9(29 \%) \quad 14(25 \%)$

3. PEP alleen

4. BCR I alleen

5. BCR I + PEP

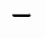

$-$

$-$

$1(17 \%)$

$1(20 \%)$

$-$

$2(8 \%)$

$3(10 \%) \quad 5(9 \%)$

$-$

$2(6 \%) 2(4 \%)$

6. BCR I + VAR

$1(17 \%)$

$1(9 \%)$

$2(8 \%)$

$1(3 \%) \quad 3(6 \%)$

7. PEP * VAR

$1(20 \%)$

$2(18 \%)$

$3(12 \%)$

$3(10 \%) \quad 6(11 \%)$

$3(10 \%) \quad 3(6 \%)$

8. PEP + VAR

+ BCR I

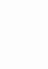

$1(40 \%)$

$1(2 \%)$ 
Aantallen normale en afwijkende neurafysiologische tests (VAR, BCR , PEP) alleen en in combinatie bij 75 mannelijke en vrouwelijke diabetici zonder en met urologische afwijkingen maar zonder klachten

\begin{tabular}{lllllll} 
zonder & \multicolumn{7}{l}{ met } \\
urologische afwijkingen $(\mathrm{N}=31)$ & \multicolumn{3}{l}{ urologische afwijkingen $(\mathrm{N}=44)$} \\
mannen vrouwen totaal & mannen & vrouwen totaal \\
$13(52 \%)$ & $2(33 \%)$ & $15(48 \%)$ & $1(14 \%)$ & $12(32 \%)$ & $13(30 \%)$ \\
$4(16 \%)$ & $2(33 \%)$ & $6(19 \%)$ & $3(43 \%)$ & $10(32 \%)$ & $13(30 \%)$ \\
$3(12 \%)$ & $1(17 \%)$ & $4(13 \%)$ & - & $2(5 \%)$ & $2(4 \%)$ \\
- & - & - & - & $3(8 \%)$ & $3(7 \%)$ \\
$2(8 \%)$ & - & $2(6 \%)$ & $1(14 \%)$ & $1(3 \%)$ & $2(4 \%)$ \\
$3(12 \%)$ & $1(17 \%)$ & $4(13 \%)$ & $1(14 \%)$ & $5(14 \%)$ & $6(14 \%)$ \\
- & - & - & - & $4(5 \%)$ & $4(9 \%)$ \\
- & - & - & $1(14 \%)$ & - & $1(2 \%)$
\end{tabular}


Aantallen normale en afwijkende neurofysiologische bevindingen (VAR, BCR I PEP) volgens het localisatiemodel bij diabetici op basis van gespecificeerde urogenitale klachten

$\begin{array}{ll}\begin{array}{l}\text { normale klinisch- } \\ \text { neurofysiologische } \\ \text { bevindingen }\end{array} & \begin{array}{l}\text { afwijkende klinisch- } \\ \text { neurofysiologische } \\ \text { bevindingen }\end{array} \\ \text { mannen vrouwen totaal } & \text { mannen vrouwen totaal }\end{array}$

urine continentie:

\begin{tabular}{|c|c|c|c|c|c|c|}
\hline intact & $12(48 \%)$ & $4(24 \%)$ & $16(38 \%)$ & $13(52 \%)$ & $13(76 \%)$ & $26(62 \%)$ \\
\hline stress incontinentie & - & $2(40 \%)$ & $2(40 \%)$ & - & $3(6 \%)$ & $3(60 \%)$ \\
\hline urge incontinentie & $2(29 \%)$ & $8(38 \%)$ & $10(36 \%)$ & $5(71 \%)$ & $13(62 \%)$ & $18(64 \%)$ \\
\hline \multicolumn{7}{|l|}{ mictiedrang: } \\
\hline intact & $14(48 \%)$ & $12(36 \%)$ & $26(42 \%)$ & $15(52 \%)$ & $21(64 \%)$ & $36(58 \%)$ \\
\hline geen & - & $2(20 \%)$ & $2(15 \%)$ & - & $8(80 \%)$ & $11(85 \%)$ \\
\hline \multicolumn{7}{|l|}{ passagegevoel: } \\
\hline intact & $13(43 \%)$ & $12(34 \%)$ & $25(38 \%)$ & $17(57 \%)$ & $23(66 \%)$ & $40(62 \%)$ \\
\hline geen & $1(50 \%)$ & $2(25 \%)$ & $3(30 \%)$ & $1(50 \%)$ & $6(75 \%)$ & $7(70 \%)$ \\
\hline \multicolumn{7}{|l|}{ blaasledigingsgevoel: } \\
\hline intact & $12(41 \%)$ & $13(37 \%)$ & $25(39 \%)$ & $17(59 \%)$ & $22(63 \%)$ & $39(61 \%)$ \\
\hline geen & $2(67 \%)$ & $1(14 \%)$ & $3(30 \%)$ & $1(33 \%)$ & $6(86 \%)$ & $7(70 \%)$ \\
\hline \multicolumn{7}{|l|}{ libido: } \\
\hline intact & $12(46 \%)$ & $7(39 \%)$ & $19(43 \%)$ & $14(54 \%)$ & $11(6+\%)$ & $25(57 \%)$ \\
\hline geen & $2(50 \%)$ & $3(60 \%)$ & $5(56 \%)$ & $2(50 \%)$ & $2(40 \%)$ & $4(44 \%)$ \\
\hline \multicolumn{7}{|l|}{ erectie: } \\
\hline intact & $5(50 \%)$ & - & $5(50 \%)$ & $5(50 \%)$ & - & $5(50 \%)$ \\
\hline geen & $9(45 \%)$ & - & $9(45 \%)$ & $11(55 \%)$ & - & $11(55 \%)$ \\
\hline \multicolumn{7}{|l|}{ ejaculatie:" } \\
\hline intact & $13(62 \%)$ & - & $13(62 \%)$ & $8(38 \%)$ & - & $8(38 \%)$ \\
\hline aen & $1(11 \%)$ & - & $1(11 \%)$ & $8(89 \%)$ & - & $8(89 \%)$ \\
\hline \multicolumn{7}{|l|}{ orgasme: } \\
\hline anwezig & $13(54 \%)$ & $5(33 \%)$ & $18(46 \%)$ & $11(46 \%)$ & $10(67 \%)$ & $21(54 \%)$ \\
\hline en & $1(17 \%)$ & $4(57 \%)$ & $5(38 \%)$ & $5(83 \%)$ & $3(43 \%)$ & 8. $(62 \%)$ \\
\hline
\end{tabular}


7.2.3. AANTALLEN NORMALE EN AFWIJKENDE NEUROFYSIOLOGISCHE TESTS (VAR, BCP I, PEP, PHEP) AFZONDERLIJK EN IN COMBINATIE BIJ DIABETICI MET UROGENITALE KLACHTEN EN/OF UROLOGISCHE AFWIJKINGEN

Tabel 7.48

Aantallen normale en afwijkende neurofysiologische tests (VAR, BCR I, PEP, PHEP) alleen en in combinatie bij 37 mannelijke en vrouwelijke diabetici zonder en met urogenitale klachten en tevens vastgestelde urologische afwijkingen

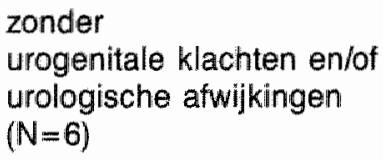

mannen vrouwen totaal met urogenitale klachten en/of urologische afwijkingen $(\mathrm{N}=31)$

mannen wrouwen totaal

1. Geen afwijkingen $3(75 \%) \quad 1(50 \%) \quad 4(67 \%) \quad 7(54 \%) \quad 5(28 \%) \quad 12(39 \%)$

2. VAR alleen

3. PEP alleen

4. BCR I alleen

5. PHEP alleen

6. PEP + VAR

7. BCR I + VAR

8. PHEP + VAR

9. PEP + BCR I

10. PEP + PHEP -

11. BCF | + PHEP -

12. PEP + BCR I + VAR

13. $V A F+P E P$ + PHEP

14. VARI + BCR I + PHEP

15. PEP + BCR I + PHEP

16. $P E P+B C R \mid$

+ PHEP

+ VAR
$1(25 \%) \quad-$

$1(17 \%)$

$2(15 \%)$

$-$

$-$

$1(50 \%)$

$1(17 \%)$

$1(8 \%)$

$1(6 \%)$

$2(6 \%)$

-

$-$

$1(6 \%)$

$1(3 \%)$

$-$

$1(8 \%) \quad \pi(6 \%) \quad 2(6 \%)$

$1(8 \%) 2(11 \%) \quad 3(10 \%)$

$-$

$-$

-

$-$

$1(8 \%)$

$1(3 \%)$

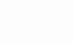$$
-
$$$$
-
$$

$1(6 \%)$

$1(3 \%)$ 
7.2.4. AANTALLEN NORMALE EN AFWIJKENDE NEUROFYSIOLOGISCHE TESTS (VAR, BCR I PEP) VOLGENS HET LOCALISATIEMODEL.

BIJ PATIENTENSUBGROEPEN OP BASIS VAN GESPECIFICEERDE UROGENITALE KLACHTEN

Voor een overzicht van deze aantallen bij gespecificeerde urogenitale klachten zie appendix 7.2.4. (tabellen $7.49 \mathrm{t} / \mathrm{m} 7.56$ ).

\subsubsection{AANTALLEN NORMALE EN AFWIJKENDE NEUROFYSIOLOGISCHE TESTS (VAR, BCR I, PEP) VOLGENS HET LOCALISATIEMODEL BIJ PATIENTENSUBGROEPEN OP BASIS VAN GESPECIFICEERDE UROLOGISCHE AFWIJKINGEN}

\section{DETRUSORGEDRAG}

In het kader van dit urodynamisch onderzoek werd bij patienten met diabetes mellitus eerst getracht het gedrag van de detrusor te classificeren in drie categoriën:

1. Normaal gedrag.

2. Hyperactiviteit van de detrusor (hyperreflexie).

Deze kan in het algemeen de manifestatie zijn van een 'unstable bladder' of van een neurogeen blaaslijden.

3. Verminderde of afwezige activiteit van de detrusor (hyporeflexie).

Dit kan de uiting zijn van een gedecompenseerde detrusor als gevolg van een infravesicale obstructie of van een neurogeen blaaslijden, al of niet gepaard gaande met een hypo-aesthesie van de blaaswand.

Bij detrusorhyperreflexie kunnen de volgende urodynamische bevindingen voorkomen:

- Tijdens de vullingsfase drukverhogingen hoger dan $15 \mathrm{~cm} \mathrm{H2O}$, al dan niet geprovoceerd door hoesten. Soms zij.jn deze detrusorcontracties niet te onderdrukken, zodat een onvrijwillige mictie optreedt.

- Een kleine blaascapaciteit.

- Het optreden van mictiedrang bij geringe blaasvulling.

- Een hoge intravesicale druk bij de mictie.

- Trabekulatie van de blaaswand.

- Het aspect van de cystometrische curve is vaak karakteristiek:

een korte naar links verschoven curve met grillige pieken, in feite vaak mede een combinatie van meerdere bovengenoemde gëlsoleerde kenmerken.

Bij detrusorhyporeflexie kunnen de volgende urodynamische bevindingen voorkamen:

- Een onvolledige ontlediging van de blaas (residu).

- Tijdens de vullingsfase - maar vaak ook bij de mictie - een afwezigheild van hyperactieve detrusorcontracties. De intravesicale druk is vaak op het einde van de vulling nauwelijks of niet hoger dan in het begin van de vulling.

- Een mictiedrang, die pas optreedt bij grotere blaasvulling.

- Een lage intravesicale druk bij de mictie. Vaak wordt een mictie zelfs niet bereikt.

- Een grote blaascapaciteit.

- Het aspect van de cystometrische curve is vaak karakteristiek:

een lange, vlakke naar rechts verschoven curve, in feite vaak mede het resultaat van een combinatie van meerdere bovengenoemde geïsoleerde kenmerken.

In deze studie werden patienten met een infravesicale obstructie - meestal met een obstructief prostaatlijden - van deze classificatie uitgesloten. Urineretentie, een atonie van de detrusor en een grote blaascapaciteit kunnen het gevolg zijn van een gedecompenseerde detrusor bij een mechanische afvloedbelemmering van de blaas. Evenzo kan een prostaatlijden gepaard gaan met een hoge mictiedruk, met een 
Trabekulatie van de blataswand of met onstabiele detrusorcontracties.

Alhoewel het aspect van de curve vaak doorslaggevend is in de beoordelling van een cystometrogram, hebben wij een poging gedaan het gedrag van de detrusor zo volledig mogelik te evalueren en te codificeren.

Aan elk van de bowengenoemde kenmerken werd daarom een aantal punten toegekend, nalargelang zij geacht werden min of meer gewicht in de schaal te leggen voor de classificatie. Aldus kwamen wij tot het volgende puntensysteem:

Urodynamische kenmerken voor detrusorhyperreflexie:

- Karakteristieke curve

4 punten

- Blaascapaciteit $<100 \mathrm{ml}$

3 punten

- Blaascapaciteit < $250 \mathrm{ml}$

2 punten

- Maximale mictiedruk $>100 \mathrm{~cm}$ water

2 punten

- Maximale mictiedruk $>80 \mathrm{~cm}$ water

1 punt

- Mictiedrang bij vulling $<50 \mathrm{ml}$

- Trabekulatie van de blaaswand zonder obstructie

1 punt

1 punt

Haalde een kenmerk of een combinatie van kenmerken minimaal 4 punten, dan werd de patient geclassificeerd in de categorie 'detrusorhyperreflexie'.

Urodynamische kenmerken voor detrusorhyporeflexie:

- Karakteristieke curve

4 punten

- Residu $>30 \%$ van de blaascapaciteit

3 punten

- Residu $>10 \%$ van de blaascapaciteit

2 punten

- Blaascapaciteit > $800 \mathrm{ml}$

3 punten

- Blaascapaciteit > $>600 \mathrm{ml}$

- Mictiedrang bij vulling $>450 \mathrm{ml}$

1 punt

- Mictiedrang bij vulling $>300 \mathrm{ml}$

3 punten

- Maximale mictiedruk $<5 \mathrm{~cm}$ water

1 punt

2 punten

- Maximale mictiedruk $<25 \mathrm{~cm}$ water

1 puint

Om een patient te classificeren bij de categorie "detrusorhyporeflexie" werd op dezelfde wijze te werk gegaan als bij de categorie 'detrusorhyperreflexie'.

Om het gedrag van de detrusor exacter te amschrijven werd overwogen de druk-volume relatie van de blaas tijdens de vulling in de classificatie te betrekken. Deze reactie wordt uitgedrukt in de compliance (V/P), waarbij $V$ de toeneming van het volume en $P$ de toeneming van de druk weergeeft. In de praktijk echter bleek het niet mogelijk dit element op uniforme wijze op onze cystometrische curves toe te passen.

Tabel 7.57

Indeling naar puntenaantal met uitsluiting van het aspect van de urodynamische curve (9 patienten hadden onvolledige gegevens)

$\begin{array}{llc}\text { punten } & \text { hyporeflexie } & \text { hyperreflexie } \\ & N & N \\ 0 & 21 & 43 \\ 1 & 21 & 5 \\ 2 & 7 & 2 \\ 3 & 6 & 3 \\ 4 & 4 & 3\end{array}$


Bij een indeling naar puntenaantal met in achtneming van kenmerken voor detrusorhyperreflexie en detrusorhyporeflexie, zonder infravesicale obstructio, bi] 59 diabetici met uitsluiting van het aspect van de urodynamische curve, komen de gegevens als vermeld in tabel 7.57 naar voren.

Maken wij een indeling naar punten en betrekken wij daarbij wel het karakteristieke aspect van de curve ( 4 puntem), dan zien wij dat de 3 patienten in de categorie hyperreflexie, die op grond van de geisoleerde kenmerken 4 punten halen, 8 punten scoren. Zij blijken dus een karakteristieke hypertone curve te hebben (tabel 7.58)

Betrekken wij bij de 4 diabetici met kenmerken van detrusorhyporeflexie (4 punten) de hypotone curve, dan zien wij dat géén van de onderzochte patienten een score 8 behaalt. Hieruit volgt, dat bij deze 4 patienten het karakteristieke aspect van de hypotone curve niet werd vastgesteld (tabel 7.58).

Tabel 7.58

Indeling naar puntenaantal zonder en met in achtneming van het karakteristieke aspect van de urodynamische curve

$\begin{array}{lll}\text { punten } & \text { hyporeflexie } & \text { hyperreflexie } \\ 4 \quad \begin{array}{l}\text { (zonder gebruikmaking } \\ \text { urodynamische curve) }\end{array} & 4 & 3 \\ 8 \quad \begin{array}{l}\text { (met gebruikmaking } \\ \text { urodynamische curve) }\end{array} & - & 3\end{array}$

Door toepassing van de puntenindex vinden wij nauwelijks patienten die beantwoorden aan de criteria voor detrusor hypo- en hyperreflexie. Het aspect van de curve blijft van doorslaggevende betekenis.

Aantallen normale en afwijkende neurofysiologische tests (VAR, BCR I, PEP) bij diabetici met een score 4 van de puntentelling met uitsliuiting van de urodynamische curve, worden vermeld in tabel 7.59 . 
Aantallen nomale en afwijkende neurofysiologische tests (NAR, BCR I, PEP) bif diabetici met een score 4 van de puntentelling zonder gebruik te maken van de urodynamische curve

$\begin{array}{lll} & \text { hyporeflexie } & \text { hyperreflexie } \\ & N & N \\ \text { normale neurofysiologische bevindingen } & - & 1(50 \%) \\ \text { abnormale neurofysiologische bevindingen } & 3(100 \%) & 1(50 \%)\end{array}$

Bij 2 patienten met score 4 waren de gegevens onvolledig.

In de tabel $7.60 \mathrm{t} / \mathrm{m} 7.65$ wordt de waarschijnlijke localisatie van de verschillende laesies vermeld, op basis van 3 neurofysiologische tests (VAR, BCR I en PEP), bij diabetici met gespecificeerde urologische afwijkingen. 


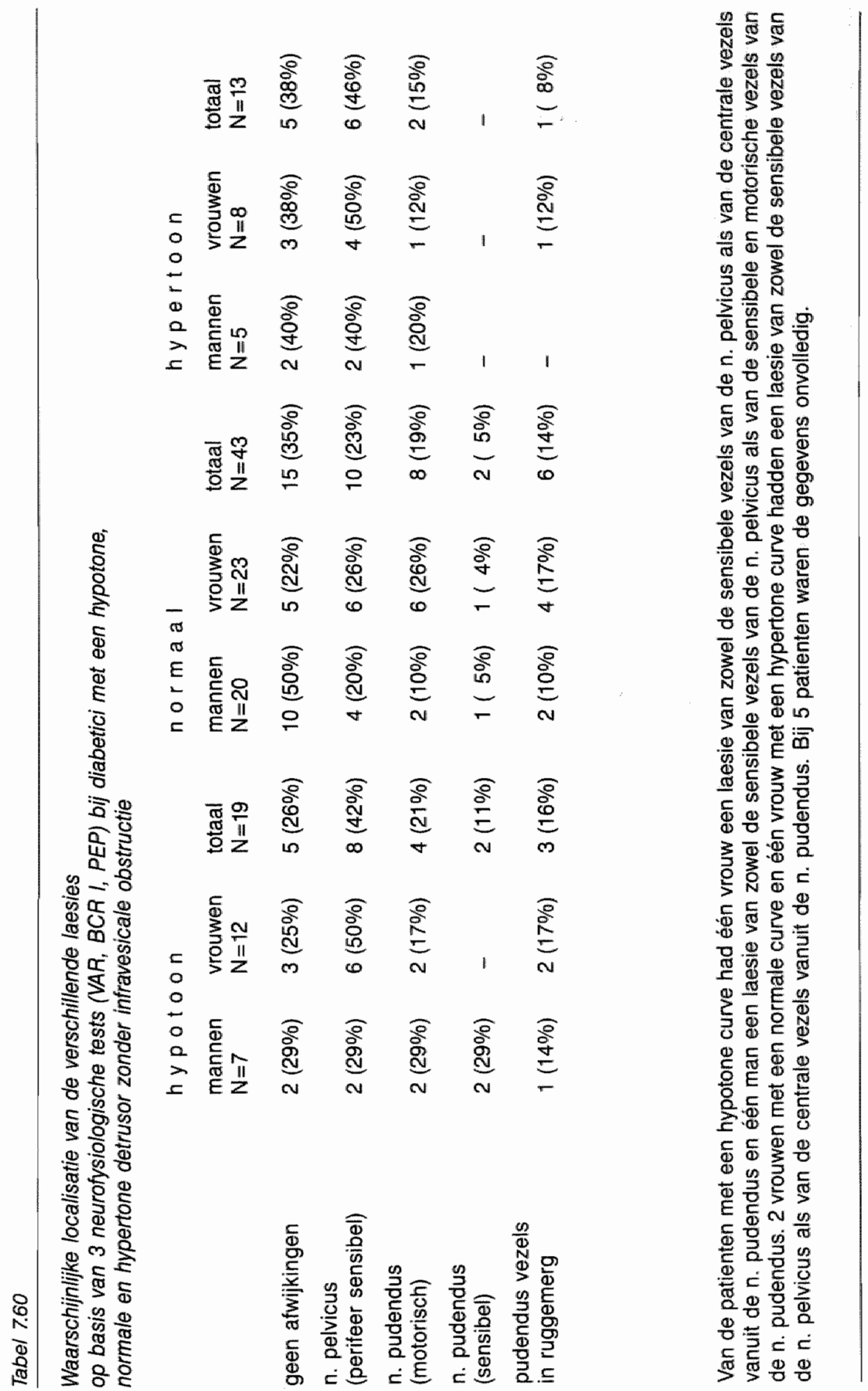


Wij beschouwden het residu als acceptabel indien het kleiner was dan $10 \%$ van de blaascapaciteit. Bij 13 patienten (5 mannen en 8 vrouwen) met en zonder infravesicale obstructie was dit residu pathologisch.

Betrokken wij alleen de patienten zonder infravesicale obstructie erbij, dan hadden slechts 8 vrouwelijke diabetici een residu dat pathologisch was. De 5 mannelijke diabetici met een pathologisch residu hadden allen een infravesicale obstructie.

Tabel 7.61

Waarschijnlijke localisatie van de verschillende laesies op basis van 3 neurofysiologische tests (VAR, BCR I, PEP, bil diabetici zonder en met een pathologisch residu

\begin{tabular}{|c|c|c|c|c|c|c|}
\hline & norma & a 1 & & verho & $g d$ & \\
\hline & $\begin{array}{l}\text { mannien } \\
N=25\end{array}$ & $\begin{array}{l}\text { vrouwen } \\
N=34\end{array}$ & $\begin{array}{l}\text { totaal } \\
N=59\end{array}$ & $\begin{array}{l}\text { mannen } \\
N=5\end{array}$ & $\begin{array}{l}\text { Wrouwen } \\
N=8\end{array}$ & $\begin{array}{l}\text { totaal } \\
N=13\end{array}$ \\
\hline geen afwijkingen & $14(56 \%)$ & $13(38 \%)$ & $27(46 \%)$ & - & $1(12 \%)$ & $1(8 \%)$ \\
\hline $\begin{array}{l}\text { n. pelvicus } \\
\text { (perifeer sensibel) }\end{array}$ & $5(20 \%)$ & $12(35 \%)$ & $17(29 \%)$ & $3(60 \%)$ & $3(37 \%)$ & $6(46 \%)$ \\
\hline $\begin{array}{l}\text { n. pudendus } \\
\text { (motorisch) }\end{array}$ & $2(8 \%)$ & $6(18 \%)$ & $8(14 \%)$ & $2(20 \%)$ & $3(37 \%)$ & $5(38 \%)$ \\
\hline $\begin{array}{l}\text { n. pudendus } \\
\text { (sensibel) }\end{array}$ & $2(8 \%)$ & $1(3 \%)$ & $3(5 \%)$ & $2(20 \%)$ & - & $2(15 \%)$ \\
\hline $\begin{array}{l}\text { udendus vezels } \\
\text { ruggemerg }\end{array}$ & $2(8 \%)$ & $6(18 \%)$ & $8(14 \%)$ & - & $1(12 \%)$ & $1(8 \%)$ \\
\hline
\end{tabular}

Van de patienten zonder een pathologisch residu hadden 4 vrouwen een laesie van zowel de sensibele vezels van de $n$. pelvicus als van de centrale vezels vanuit de $n$. pudendus. Eén man met een pathologisch residu had een laesie van zowel de sensibele vezels van de $n$. pelvicus als van de sensibele en motorische vezels van de n. pudendus. Bij 8 patienten waren de gegevens onvolledig.

\section{BLAASCAPACITEIT}

De blaascapaciteit werd afwijkend bevonden indien deze groter was dan $600 \mathrm{ml}$ of kleiner dan $250 \mathrm{ml}$. 


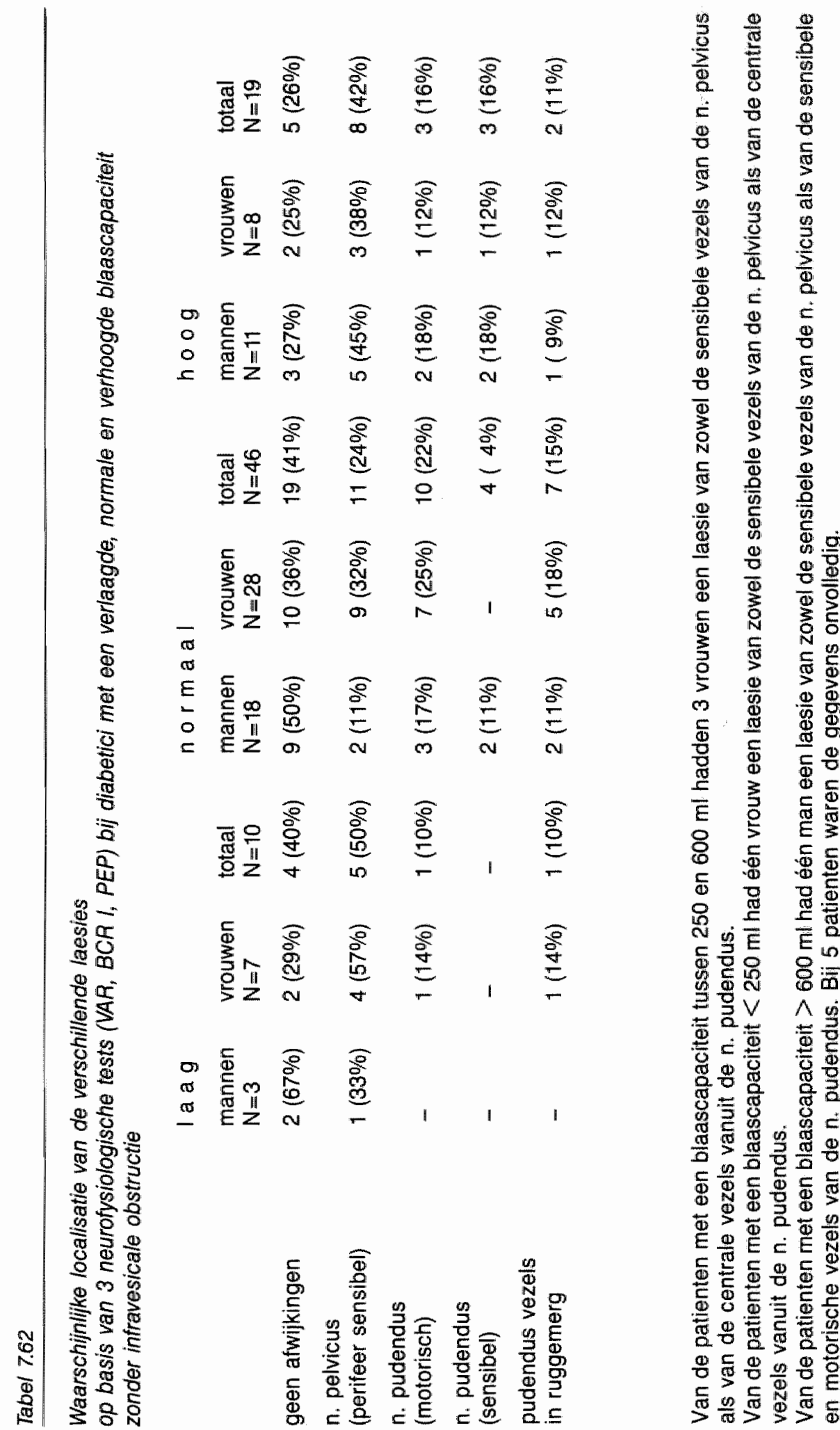




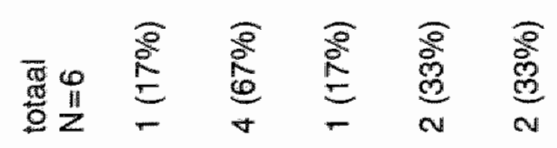

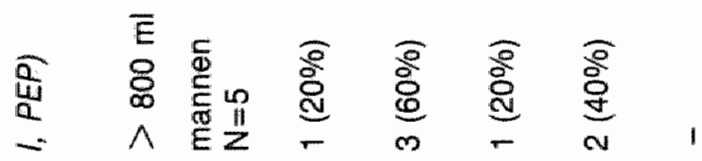

$\frac{\sigma}{0}$

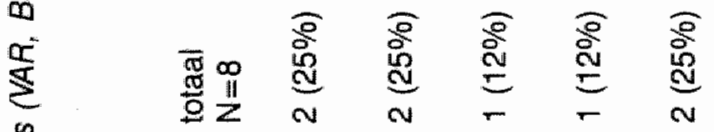

$\frac{\mathscr{2}}{5}$

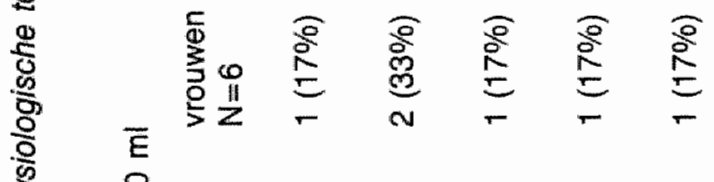

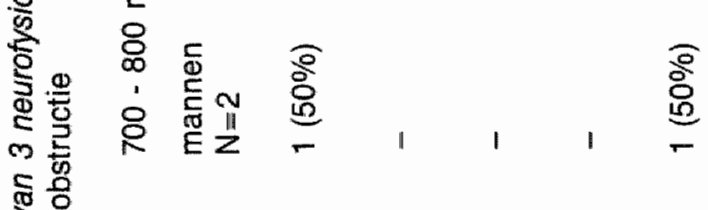

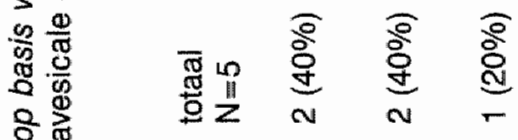

呟

递

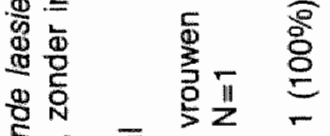

$\stackrel{\bar{E}}{\bar{E}}$

$\sum_{\frac{5}{5}}^{\frac{5}{2}} \stackrel{8}{8}$

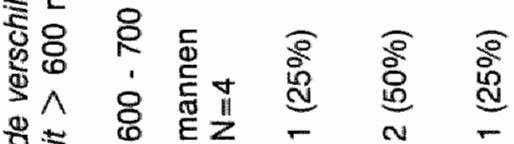

ษ

$5 \frac{9}{0}$

$>\mathbb{8}$

.

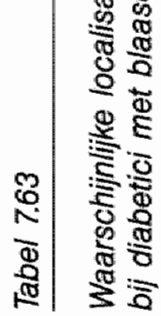

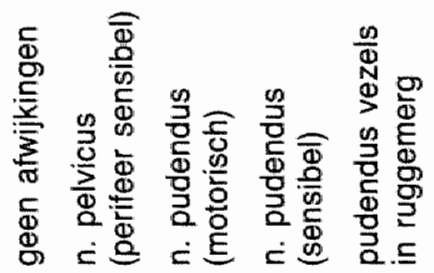


EERSTE AANDRANG

De eerste aandrang werd afwijkend bevonden indien deze later optrad dan $300 \mathrm{ml}$ en vroeger dan $50 \mathrm{ml}$. 


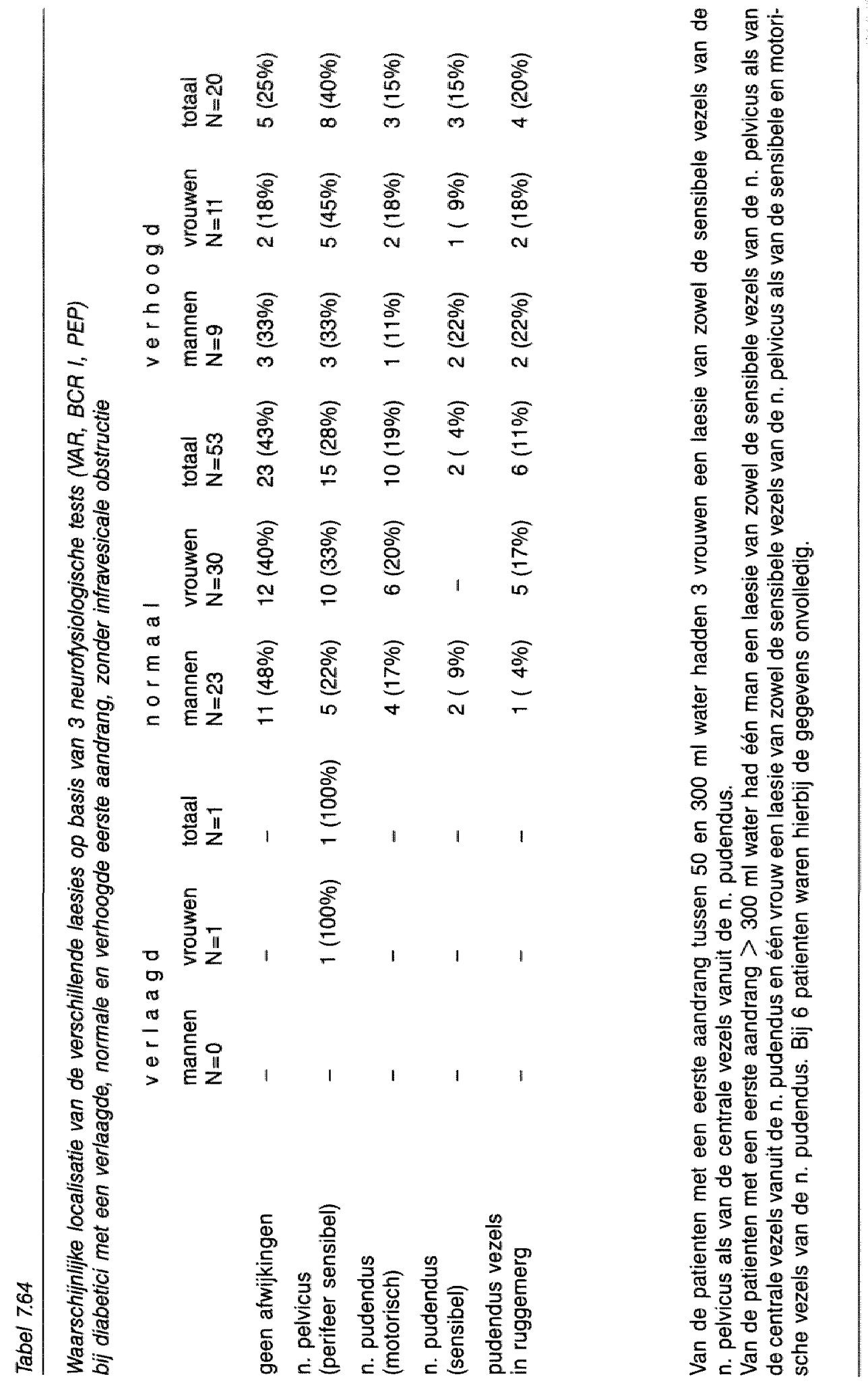




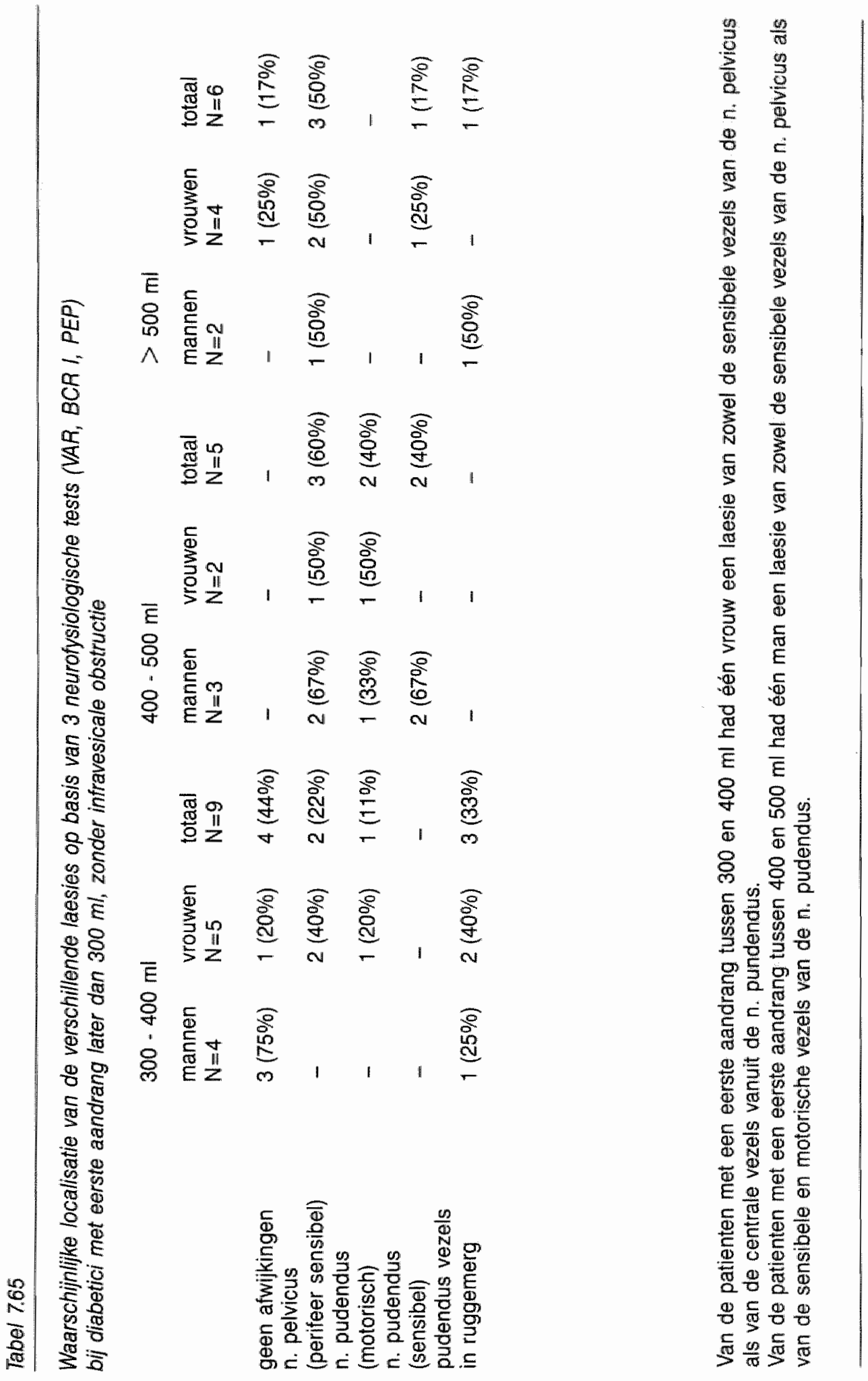


Tabel 766

Aantallen normale en afwikkende neurofysiologische bewindingen (VAR, BCR I, PEP) volgens het localisatiemodel bij diabetici op basis van urodynamische parameters

normale klinisch-
neurafysiologische
bevindingen

abnormale klinischneurofysiologische bevindingen

Residu:

geen

$27(46 \%)$
$1(8 \%)$

$32(54 \%)$

verhoogd

$4(40 \%)$

$12(92 \%)$

Blaascapaciteit:

$<250 \mathrm{ml}$

$19(41 \%)$

$6(60 \%)$

$250-600 \mathrm{ml}$

$>600 \mathrm{ml}$

$5(26 \%)$

$27(59 \%)$

$1(17 \%)$

$14(74 \%)$

$>800 \mathrm{ml}$

$5(83 \%)$

Eerste aandrang:

$<50 \mathrm{ml}$

$50-300 \mathrm{ml}$

$>300 \mathrm{ml}$

$>500 \mathrm{ml}$

$23(43 \%)$

$5(25 \%)$

$1(17 \%)$

Detrusorgedrag:

hypotoon

normaal

hypertoon
$5(26 \%)$

$15(35 \%)$

$5(38 \%)$
$1(100 \%)$

$30(57 \%)$

$15(75 \%)$

$5(83 \%)$

$14(74 \%)$

$28(65 \%)$

$8(62 \%)$

\subsubsection{CONCLUSIES}

Bij $80 \%$ van de insuline afhankelijke en $48 \%$ van de niet insuline afhankelijke diabetici werden neurofysiologische afwijkingen gevonden.

Laesies van de innervatie van het urogenitale systeem kunnen bij diabetici op perifeer en centraal niveau, geissoleerd en in combinatie voorkomen.

$\mathrm{Bij} 8 \%$ van de onderzochte diabetici werden door middel van EMG onderzoek van de $\mathrm{m}$. sphincter ani externus afwijkingen gevonden die niet aantoonbaar waren via reflexmeting.

Het aantal gediagnostiseerde centrale laesies na toepassing van de VAR, BCA I en PEP was even groot als na toepassing van de VAR, BCR ॥, PEP en PHEP. De PHEP gaf dus geen aanvullende informatie boven de PEP.

Een laesie van de centrale vezels van de $n$. pelvicus ging bij de onderzochte diabetici altijd samen met een gediagnostiseerde laesie van de $n$. hypogastricus. Omgekeerd is dit niet altijd het geval.

$83 \%$ Van de onderzochte diabetici had één of meer urogenitale klachten en $68 \%$ één of meer urologische afwijkingen. Bij de anamnestische parameters was vooral de erectie 
vaak afwezig (62\%) en bij de urologische parameters was de detrusorcurve het meest afwijkend $(43 \%)$.

Door toepassing van punten die de kenmerken van het detrusorgedrag aangeven, werden slechts enkele patienten gevondien die beantwoordden aan de criteria van detrusor hypo- en hyperreflexie.

Bij $26 \%$ van de 35 insuline afhankelijke diabetici en $25 \%$ van de 40 niet insuline afhankelijke diabetici was meer dan één neurofysiologische test afwijkend.

Het percentage van voorkomen van patienten met urogenitale klachten en urologische afwijkingen was bij patienten met één laesie $40 \%$ en bij patienten met meer laesies $25 \%$. Het percentage van voorkomen van patienten zonder urogenitale klachten en urologische afwijkingen was bij patienten met één laesie $11 \%$ en bij patienten met meer laesies 33\%.

Aantallen afwijkende neurofysiologische bevindingen van VAR, BCR I en PEP volgens het localisatiemodel op basis van gespecificeerde urogenitale klachten en urologische afwijkingen waren duidelijk groter dan bij metingen van tests alleen. Dit gold vooral voor mictiedrang, ejaculatie, residu, blaascapaciteit en eerste aandrang.

Een innervatiestoornis van het urogenitale systeem als oorzaak van een urogenitale functiestoornis kon bij de onderzochte diabetici niet worden aangetoond. 


\section{HOOFDSTUK 8 \\ SLOTBESCHOUWING}

In de patientengroep worden bil klinisch-neurofysiolgisch onderzoek beduidend meer afwijkingen gevonden dan in de controlegroep. Getracht werd een relatie te vinden tussen de verschillende klinisch-neurofysiologische bevindingen en urogenitale klachten en afwijkingen. Ondanks onderverdeling in talrijke subgroepen blijkt de relatie tussen afwijkende neurofysiologische tests, urogenitale klachten en urologische afwijkingen gering. Alleen mictiedrang, residu en maximale mictiedruk hebben een voorspellende waarde betreffende een neurofysiologische afwijking.

Wij hebben getracht het gedrag van de detrusoraktiviteit zo objectief mogelijk to evalueren en te classificeren via een puntensysteem. Door toepassing van het puntensysteem vinden wij slechts enkele patienten, die beantwoorden aan de criteria voor detrusorhypo- en hyperreflexie. Het aspect van de curve blijt urologisch gezien van doorslaggevende betekenis voor de beoordeling van het cystometrogram.

Teleurstellend is, dat er geen significante samenhang wordt gevonden tussen het detrusorgedrag en de klinisch-neurofysiologische bevindingen. Dit laatste zowel zonder als met gebruik van het localisatie model.

De PEP was zelfs significant vaker gestoord bij urologische afwijkingen die volgens de literatuur op een perifere laesie moeten berusten.

De H-reflex (H-M interval) en de TEP waren bij de diabetici veelvuldig afwijkend, vaak in combinatie met stoornissen van de urogenitale innervatie. Het is derhalve aannemelijk dat deze innervatiestoornissen doorgaans deel uitmaken van een meer algemene perifere neuropathie en/of myelopathie, welke blijkbaar geheel of gedeeltelijk subklinisch kan ziin.

Het belang van differentiatie iussen somatische en psychogene oorzaken bij sexuele functiestoornissen bij zowel mannen als vrouwen is groot. In dit onderzoek valt op dat het percentage klinisch-neurofysiologische afwijkingen bij diabetici met en zonder sexuele functiestoornissen (libido, erectie, ejaculatie en orgasme) nagenoeg gelijk is. Een innervatiestoornis als oorzaak van een sexuele functiestoornis kan in dit onderzoek bij deze groep diabetici niet overtuigend worden aangetoond.

\section{OVERWEGINGEN BETREFFENDE HET ONTBREKEN VAN EEN SAMENHANG} TUSSEN KLINISCH-NEUROFYSIOLOGISCHE BEVINDINGEN EN ANAMNESE ENERZIJDS EN URODYNAMISCHE PARAMETERS ANDERZIJDS

Bij diabetes mellitus vindt men regelmatig verscheidene laesies, in meer of minder ernstige mate, zowel van het somatische als het autonome zenuwstelsel.

Deze laesies behoeven niet altijd te leiden tot functieverlies of klachten.

Alleen bij ziekten met een enkelvoudige laesie van het urogenitale systeem is onderzoek naar de samenhang tussen het klinisch-neurofysiologisch en het urodynamisch onderzoek goed mogelijk.

\section{ANAMNESTISCH ONDERZOEK}

Hoewel de anamnese betreffende de sexuele functies bij alle onderzochte patienten zo nauwkeurig mogelijk werd afgenomen, was deze gezien het karakter van de vragen niet 
geheel betrouwbaar. Oudere mannelijke en vrouwelijke patienten konden vaak de vragen betreffende het sexueel functioneren niet beantwoorden. Geen van de diabetici had moeite met het beantwoorden van de vragen betreffende mictie en defaecatie.

\section{URODYNAMISCH ONDERZOEK}

Bij het urodynamisch onderzoek worden bevindingen gedaan als bij een lower of upper motor neuron aandoening zonder dat deze neurofysiologisch aangetoond kan worden. Lower motor neuron laesies ziet men in de regel bij een laesie van het sacrale deel van het ruggemerg, cauda equina en n. pelvicus en leiden tot detrusorhyporeflexie. Upper motor neuron laesies ziet men in het algemeen bij laesies boven het sacrale merg. Deze kunnen leiden tot detrusorhyperreflexie.

Hetzelfde urodynamisch beeld (detrusorhypo-en detrusorhyperreflexie) kan men ook vinden bij niet-neurogene aandoeningen (zie hoofdstuk 4.2.: beschrijving urologische onderzoekmethoden).

Er kan ook een discrepantie zijn wat betreft de bevindingen bij het urodynamisch onderzoek zelf.

Opvallend was in dit verband (zie hoofdstuk 7.2.5.) dat bij enkele patienten met diverse urodynamische kenmerken passend bij detrusorhyporeflexie, geen karakteristieke hypotone curve werd vastgesteld.

\section{NEUROFYSIOLOGISCH ONDERZOEK}

De mictiereflex is een hersenstamreflex "die afhankelijk is van het intact zijn van de lange baansystemen in het ruggemerg, hersenstam reticulaire formatie en perifere systemen. Deze perifere systemen bestaan uit het somatische zenuwstelsel (sensibel en motorisch), het autonome zenuwstelsel (parasympathisch en sympathisch) en sacrale en lumbale afferenten.

Niet alle zenuwsystemen, die betrokken zijn bij mictie en sexuele functies, worden in dit onderzoek gemeten, met name voor de motorische vezels in de $n$. pelvicus en de descenderende banen (tractus reticulospinalis) in het ruggemerg ontbreken tot op heden geschikte onderzoekmethoden.

Een laesie van de eerste kan leiden tot detrusorhyporeflexie en van de tweede tot een detrusorhyperreflexie.

De oorzaak voor het niet goed verlopen van een blaascontractie kan ook gelegen zijn in een gestoorde transmissie ter plaatse van ganglioncellen of een stoornis van de neuromusculaire overgang.

Aanzienlijke neurofysiologische afwijkingen kunnen gevonden worden bij een volkomen normaal urodynamisch onderzoek. Door ons werd bij een patient met een spinal stroke een laesie van de interneuronen van area VII pathologisch anatomisch aangetoond. Deze patient toonde aanzienlijke neurofysiologische afwijkingen en had een volkomen normaal urodynamisch onderzoek (ongepubliceerde waarneming).

Alhoewel er geen samenhang is tussen de verschillende parameters kan men door het toepassen van de beschreven reflexen en evoked potentials, tesamen met het elektromyografisch onderzoek van de $\mathrm{m}$. sphincter ani externus een laesie van het perifere systeem (afferentie, sacrale merg S2 tot en met S4, efferentie) vaststellen en een laesie van het centrale systeem tot op zekere hoogte waarschijnlijk maken.

Men kan aldus een stoornis in het perifere en centrale systeem localiseren en kwantificeren. Dit kan betekenis hebben bij het diagnostiseren van ziekten van het ruggemerg of van ziektebeelden waarbij multipele laesies optreden. Dit is bijvoorbeeld het geval bij diabetes mellitus of demyeliniserende ziekten. Dit onderzoek kan wellicht ook een functie hebben bij het selecteren van patienten die voor elektrostimulatie in aanmerking komen. Elektrostimulatie heeft namelijk alleen zin indien de gestimuleerde zenuw intact is. Dit is bijvoorbeeld het geval bij patienten met een 'unstable bladder'. 


\section{Hoofdstuk 1}

Het doel van de studie was om door middel van klinisch-neurofysiologisch onderzoek na te gaan of er bij patienten met diabetes mellitus innervatiestoornissen van het urogenitale systeem aantoonbaar zijn, deze innervatiestoornissen te localiseren, en de resultaten te vergelijken met het urodynamisch onderzoek enerzijds en de anamnese van mictie- en/of sexuele functiestoornissen anderzijds.

\section{Hoofdstuk 2}

In dit hoofdstuk wordt een literatuuroverzicht gegeven van de anatomie en de fysiologie vam het urogenitaalstelsel.

Hoewel veel literatuur hieraan is gewijd $\mathrm{d}_{4}$ is de neurofysiologie van de mictie en genitale functies nog slechts ten dele opgehelderd. Bovendien zijn de gegevens in de literatuur vaak tegenstrijdig.

In het laatste deel van dit hoofdstuk wordt een opsomming gegeven van de alpha- en betareceptoren in blaas, blaashals, urethra en genitaliën.

\section{Hoofdstuk 3}

De neurologische aspecten van diabetes mellitus in het kader van dit onderzoek worden belicht.

Cystoneuropathie wordt over het algemeen gevonden bij langer bestaande diabetes mellitus, doch kan ook het eerste verschijnsel van de ziekte zijn. Kenmerkend voor het klinisch beloop is het geleidelijk ontstaan van een atone blaas met urineretentie.

Het percentage van voorkomen van cystoneuropathie dat in de literatuur wordt opgegeven bij insuline afhankellijke diabetici varieert van 26 tot 87 .

Het percentage van voorkomen van sexuele functiestoornissen bij mannen in de verschillende leeftijdssgroepen varieert van 15 tot 75 . Impotentie kan evenals een cystoneuropathie de eerste klinische manifestatie bij diabetes mellitus zijn.

In tegenstelling tot het zeer frequent voorkomen van een somatische neuropathie, ziet men neurologische verschijnselen passend bij een myelopathie betrekkelijk zelden.

\section{Hoofdstuk 4}

In dit hoofdstuk worden de diagnostische anderzoekmethoden beschreven.

In het eerste deel wordt een beschrijving gegeven van de klinisch-neurofysilologische methoden. Hiermee kunnen gegevens omtrent de centrale en perifere innervatie van het urogenitale systeem verkregen worden.

De volgende technieken werden toegepast:

1. naald $E M G$ van de $m$. sphincter ani externus en $\mathrm{m}$. bulbocavernosus

2. vesico-anale-reflex (VAR) met elektrische stimulatie van de blaashals via katheter

3. bulbocavernosusreflex (BCR I en BCR II) met elektrische stimulatie van de $n$. dorsalis penis of $n$. clitoridis

4. tibialis, pudendus en pelvicus (hypogastricus) evoked potential (TEP, PEP en PHEP) met elektrische stimulatie van resp. n. tibialis achter de malleolus medialis, n. diorsalis penis of $\mathrm{n}$. clitoridis en blaashals via katheter

5. $\mathrm{H}$-reflex met elektrische stimulatie van de $\mathrm{n}$. tibialis, Hoffmann-reflex ( $\mathrm{H}-\mathrm{M}$ interval) Het doel van dit onderzoek was om via een combinatie van deze tests te differentiëren tussen een autonoom ( $n$. pelvicus en $n$. hypogastricus), een somatisch afferent (sensibe- 
le n. pudendus), een somatisch efferent (motorische n. pudendus) en een centraal letsel (ascenderende banen achterstrenglemniscus systeem).

In het tweede deel van dit hoofdstuk wordt een beschrijving gegeven van de urodynamische onderzoekmethaden voor zover deze relevant waren voor dit onderzoek.

Er werd in het kader van dit onderzoek gebruik gemaakt van de cystometrie, de uroflowmetrie en in beperkte vorm van elektromyografie.

De cystometrie is een op zichzelf staande test van de detrusorfunctie en geeft slechts beperkt informatie over de innervatie van het urogenitale systeem. Gedurende het cystometrisch onderzoek wordt vooral gelet op blaasretentie, blaascapaciteit, contractilliteit en sensibiliteit van de blaaswand. De uroflowmetrie wordt aangewend als screeningstest voor het aantonen of uitsluiten wan een infravesicale obstructie. Door middel van het EMG onderzoek kan een detrusorsphincter-dyssynergie worden aangetoond.

\section{Hoofdstuk 5}

In dit hoofdstuk warden de onderzochte groepen beschreven.

De referentiegroep bestond uit 86 proefpersonen; 50 mannen en 36 vrouwen. De leeftijd varieerde van 15 tot 75 jaar met een gemiddelde van 43,5 jaar.

De patientengroep bestond uit 80 patienten met diabetes mellitus. Dit waren 34 mannen en 46 vrouwen tussen 28 en 91 jaar, met een gemiddelde leeftijd van 60,9 jaar. Uit deze groep waren 38 patienten insuline athankelijk, 28 werclen behandeld met orale antidiabetica on 24 alleen met dieet.

Bij alle onderzochten werd een speciële anamnese afgenomen en gevraagd naar het verloop van de mictie (aard incontinentie, mictiedrang, passagegevoel, blaasont-

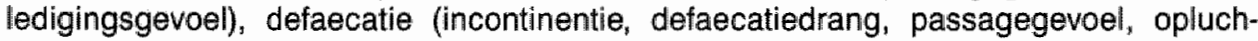
tingsgevoel) en sexuele functies (libido, erectie, ejaculatie en orgasme).

Bij de patienten met diabetes mellitus was de mictiedrang afwezig bij $18 \%$, het passagegevoel bij $14 \%$ en het blaasontledigingsgevoel bilj $16 \%$.

De erectie was bij $62 \%$ en de ejaculatie bij $29 \%$ van de mannelijke diabetici afwezig. Bij $18 \%$ van de mannen en bij $17 \%$ van de vrouwen was de beleving van het orgasme afwezig.

\section{Hoofistuk 6}

In dit hoofdstuk warden de methoden van onderzoek en onderzoekresultaten beschreven.

De in hoofdstuk 4 beschreven onderzoekmethoden werden toegepast bij de referentieen patientengroep.

In de referentiegroep waren de gemiddelde latentietijden van de PEP, TEP en H-reflex ( $H \cdot M$ interval) bij mannen significant langer dan bij vrouwen.

De latentietijden van de $\mathrm{VAR}, \mathrm{BCR}$ I en $1 / \mathrm{m}$. sphincter ani externus, PEP, TEP en H-reflex (H-M interval) waren bij de diabetici significant langer dan bij de referentiegroep.

Opvallend bij het EMG onderzoek van de $\mathrm{m}$. sphincter ani externus was dat bij $16 \%$ van de patientengroep en slechts bili $2 \%$ van de referentiegroep in rust geen motorunitaktiviwelt werd gevonden.

Het ontbreken van basisaktiviteit bij het EMG onderzoek van de m. sphincter ani extermus is een teken van een gestoorde innervatie van deze spier. Er was een duidelijke relatie tussen de mate van spontane motorunitaktiviteit en het maximaal aanspanningspatroon. Het voorkomen van fibrillatiepotentialen in de $\mathrm{m}$. sphincter ani externus was steeds gecombineerd met afwezige spontane motorunitaktiviteit en een verminderd aanspanningspatroon in deze spier.

Bij $6 \%$ van de referentiegroep werden complexe repetitieve ontladingen geregistreerd waarvoor geen verklaring kon worden gegeven.

\section{Hoofdstuk 7}

In dit hoofdstuk worden de resultaten van de neurofysiologische tests vergeleken met anamnestische en uradynamische gegevens. 
De patienten werden onderwerdeeld in subgroepen op basis van 8 anammestische en 5 urologische criteria.

Urogenitale klachten en urologische afwijkingen gaven bij patienten weinig informatie over de te verwachten klinisch-neurofysiologische bevindingen.

Bij $80 \%$ van de insuline athankelijke en $48 \%$ van de niet insuline afhankelijke diabetici werden neurofysiologische afwijkingen vastgesteld.

Na toepassing van het localisatiemodel werd gevonden dat laesies van de innervatie van het urogenitale systeem bij diabetici zowel op perifeer als centraal niveau geïsoleerd en in combinatie kunnen voorkomen.

Bij vrouwen waren de $\mathrm{H}$-reflex ( $\mathrm{H}-\mathrm{M}$ interval) en de TEP significant vaker gestoord bij een gediagnostiseerde stoornis van de perifere innervatie van het urogenitale systeem (VAR, $B C R$ I). Er was geen relatie tussen een centrale urogenitale innervatiestoormis (PEP, PHEP) en de H-reflex (H-M interval) en de TEP.

\section{Hoofdstuk 8}

In dit hoofdstuk wordt een slotbeschouwing gegeven.

Getracht werd een relatie te vinden tussen de verschillende klinisch-neurofysiologische bevindingen en urogenitale klachten en afwijkingen. Ondanks onderverdeling in subgroepen bleek de relatie tussen afwijkende neurofysiologische tests, urogenitale klachten en urologische afwijkingen gering.

In dit onderzoek viel op, dat het percentage klinisch-neurofysiologische afwijkingen bij diabetici met en zonder sexuele functiestoornissen, nagenoeg gelijk was. Een innervatiestoornis als oorzaak van een sexuele functiestoornis kon in dit onderzoek bij deze groep diabetici derhalve niet worden aangetoond.

Bij het urodynamisch onderzoek is het aspect van de curve van doorslaggevende betekenis in de beoordeling van het cystometrogram. Opvallend was dan ook, dat er geen samenhang bestond tussen het detrusorgedrag en de klinisch-neurofysiologische bevindingen. 



\section{SUMMARY}

\section{Chapter 1}

The aim of the study was to ascertain by means of clinical neurophysiological studies whether innervation disturbances of the urogenital system could be found in patients with diabetes mellitus and if these innervation disturbances could be localised, as well as to compare the results with those obtained from urodynamic studies and from any history of disturbances of micturition or sexual activity.

\section{Chapter 2}

In this chapter a review of the literature concerning the anatomy and the physiology of the genito-urinary system is presented. Although a considerable amount of literature has been dedicated to the neurophysiology of micturition and of genital functions, these have only partially been clarified. Moreover, much of the data in the literature is conflicting. In the last part of this chapter a description is given of the distribution of alpha and beta receptors in the bladder, bladder-neck, urethra and genitallia.

\section{Chapter 3}

The neurological aspects of diabetes mellitus within the framework of this study have been highlighted.

Neuropathic bladders are generally found in diabetes mellitus patients who have had the disease for a long time, but nevertheless can sometimes present as the first symptom. A characteristic of the progression of the clinical pattern is the gradual development of an atonic bladder with retention of urine. The percentage of neuropathic bladders among insulin-dependent diabetes patients varies from 26 to 87 in the literature. Moreover, the percentage of occurrence of sexual function disturbances in males in the various age groups has been shown to vary from 15 to 75 . Impotence can also be the first clinical manifestation of diabetes mellitus in the same way as cystoneuropathy.

In contrast to the very frequent occurrence of a somatic neuropathy, neurological findings which would match with a myelopathy are relatively rare.

\section{Chapter 4}

In this chapter the diagnostic methods of investigation are described.

In the first part, a description is given of the methods used for the clinical neurophysiological studies. By these methods, data concerning the central and peripheral innervation of the urogenital system can be obtained.

The following techniques were employed:

1. needle EMG of the external anal sphincter and the bulbocavernosus muscles

2. vesico-anal-reflex (VAR) with electrical stimulation of the bladder-neck through a catheter

3. bulbocavernosusreflex (BCR I and BCR II) with ellectrical stimulation of the dorsal nerve of the penis or of the nerve of the clitoris

4. tibial, pudendal and pelvic (hypogastric) nerve evoked potentials (TEP, PEP and PHEP) with electrical stimulation of the tibial nerve behind the medial malleolus, and of the dorsal nerve of the penis or clitoris and stimulation of the bladderneck via a catheter

5. H-reflex with electrical stimulation of the tibial nerve, the Hoffmann-reflex ( $\mathrm{H}-\mathrm{M}$ interval) The intention of this study was to differentiate between autonomic (pelvic and hypogastric nerves), somatic afferent (the sensory pudendal nerve), and somatic efferent ithe motor 
pudendal nerve) dysfunctions. These had to be differentiated from suprasegmental centrall lesions (involving the ascending posterior columns).

In the second part of this chapter a description is given of the urodynamic investigation methods as far as these were considered relevant for this particular study. Also within the general outline of this study, cystometry was employed together with urine flow measurements and, to a degree, electromyography.

The cystometry is a single test of detrusior function and gives only limited information about the innervation of the urogenital system. During the cystometric study special attention was paid to retention of urine, bladder capacity, contractibility, and sensitivity of the bladder wall. The flow measurement was used as a screening test for demonstration or exclusion of an infravesical obstruction. Detrusor sphincter dyssynergy could be shown by means of the EMG studies.

\section{Chapter 5}

In this chapter the patients in the various groups are described.

The reference group consisted of 86 persons: 50 males and 36 females. Their ages varied from 15 to 75 years with a mean of 43.5 years.

The patient group consisted of 80 patients with diabetes mellitus. There were 34 males and 46 females with an age range of 28 to 91 years, and mean age of 60.9 years. Thirty eight patients in this group were insulin-dependent, 28 required oral antidiabetic drugs, and 24 were managed with diet alone.

All subjects investigated had a special history taken and were asked specifically about the nature of micturition. In particular $r_{n}$ any incontinence, feeling of bladder fullness, sensation of micturition, and sense of bladder emptying were asked about. Furthermore, sexual functions such as libido, erection, ejaculation and orgasm were analysed.

There was no sensation of bladder fulliness in $18 \%$ of the patients with diabetes and $14 \%$ had no sense of passing urine. Moreover, $16 \%$ had no idea when the bladder was empty. Erection was absent in $62 \%$ of the diabetics and ejaculation was lost in $29 \%$. Orgasm was not experienced by $18 \%$ of the males and $17 \%$ of the females.

\section{Chapter 6}

In this chapter the results of the methods employed for the study are presented.

The methods (as already shown in chapter 4) were applied to both the reference and the patient groups.

The mean latency times of the PEP, TEP and H-reflex ( $\mathrm{H}-\mathrm{M}$ interval) in malles in the reference group were significantly longer than in the females. The latency times of the VAR, BCA I and II of the external anal sphincter, PEP, TEP and H-reflex (H-M interval) were significantly longer in the diabetics than in the members of the reference group. It was noteworthy that $16 \%$ of the patient group and only $2 \%$ of the reference group showed no motor unit activity of the external anal sphincter at rest during the EMG studies. The absence of basis activity in the EMG examination of the external anal sphincter is a sign of disturbed innervation of this muscle. There was a clear relation between the degree of spontaneous motor unit activity and the maximal contraction pattern in this muscle.

The occurrence of fibrillation potentials in the external anal sphincter was always combined with the absence of spontaneous motor unit activity and a reduced tension pattern. Complex repetitive discharges were registered in $6 \%$ of te reference group, for which no explanation can be given.

\section{Chapter 7}

In this chapter the results of the neurophysiological tests are compared with data from the patient history and from the urodynamic studies.

The patients were subdivided into groups on the basis of eight symptomatic and five urological criteria. Urological complaints and urological abnormalities were found to yield very little information on the expected clinical neurophysiological findings in the patients. 
Neurophysiological abnormalities were judged to be present in $80 \%$ of the insulindependent patients and $48 \%$ of the non insulin-dependent diabetics.

After application of the localisation model it was found that lesions of the innervation of the urogenital system in diabetics could just as well occur peripherally as at a central llevel, or even in combination.

The H-reflex ( $\mathrm{H}-\mathrm{M}$ interval) and the TEP were significantly more often disturbed when a disturbance of the peripheral innervation of the urogenital system had been diagnosed (VAR, BCR I). There was no relation between a central urogenital innervation disorder (PEP, PHEP) and the H-reflex ( $\mathrm{H}-\mathrm{M}$ interval) and the TEP.

\section{Chapter 8}

In this chapter a final discussion and conclusion is presented.

Attempts have been made to find a relationship between the various clinical neurological findings and the urological complaints and abnormalities. Despite division into subgroups the patients showed only a very slight correlation between abnormal neurophysiological tests, urogenital complaints and urological abnormalities.

It was particularly noteworthy in this study that the percentages of clinical neurophysiological abnormalities in diabetics with and without sexual functional disturbances were similar. An innervation disturbance as a cause of sexual function disorder could not therefore be shown in them.

With the urodynamic studies it was the aspect of the curve which was of vital importance in judging the cystometrogram. It was also impressive that there was no relationship between the detrusor pattern and the clinical neurophysiological findings. 


\section{LITERATUURLIJST}

Aagenaes OO (1963) Neurovascular examinations of the lower extremities in young diabotics with special reference to the autonomic neuropathy. Thesis, Copenhagen.

Aarseth S (1953) Cardiovascular-renal disease in diabetes mellitus: A clinical study. Acta Med Scand 281: 194-214.

Abrams PH, Torrens MJ (1979) Urine flow studies. Urol Clin North Am 6: 71-78.

Ahlqvist RP (1948) A study of adrenotropic receptors. Am J Physiol 1953: 586-600.

Allert ML, Jelasic F (1968) Das Ruhe-EMG des gesundes Blasen- und Analschliessmuskels. Dtsch Z Nervenheilk 194: 252-260.

Allert ML, Jelasic F (1970) Das Schliessmuskel-EMG der neurogen gestörten Harnblase. Nervenartz 41: 502-505.

Allert ML, Jelasic F (1972) Elektrostimulation und Bulbocavernosus Reflex. In: Allert ML, Dollfus $P$ eds Neurogene Blasenstörungen Thieme, Stuttgart 68-72.

Allert ML, Jelasic F (1974) Diagnostik neurogener Blasenstörungen durch Elektromyographie. Thieme, Stuttgart 36-37.

Allert ML, Jelasic F, Schneider H (1973) Specific EMG findings in cases of neurogenic bladder and rectal disturbances. Paraplegia 10: 262-270.

Andersen JT (1976) Detrusor hyperreflexia in benign infravesical obstruction. A cystometric study. J Urol 115: 532-534.

Andersen JT, Bradley WE (1976) The syndrome of detrusor - sphincter dyssynergila. J Urol 116: 493-495.

Andersen JT, Bradley WE (1976) Abnormalities of bladder innervation in diabetes mellitus. Urology 7: 442-448.

Andersen JT, Bradley WE (1976) Bladder and urethral innervation in multiple sclerasis. $\mathrm{Br} J$ Urol 48: 239-243.

Andersen JT, Bradley WE (1977) Neuro-urological investigation in urinary bladder dysfunction. Int Urol Nephrol 9: 133-143.

Andersen JT, Bradley WE, Timm GW (1976) Electrophysiological techniques for the study of urethrall and vesical innervation. Scand J Urol Nephrol 10: 189-194.

Andersen GF, Goellner PM, Pierce JM (1972) The electrical properties of isolated detrusor muscle as studied with the sucrose gap. Invest Urol 9: 470-473.

Andersson KE (1986) Clinical relevance of some findings in neuro-anatomy and neurophysiology of the lower urinary tract. Clin Sici 70 Suppl 14: 21-32.

Angel RW, Hoffmann WW (1963) The H-reflex in normal, spastic and rigild subjects. Arch Neurol 8: $591-596$.

Appenzeller O, Ogin G (1974) Myelinated fibers in human paravertebral sympathetic chain: White rami communicantes in alcoholic and diabetic patients. I Neurol Neurosurg Psychiatry 37: $1155-1165$.

Arezzo J, Leglatt AD, Vaughan $H G$ (1979) Topography and intracranial sources of somatosensory evoked potentials in the monkey: Early components. Electroencephalogr Clin Neurophysiol 46: 155-172. 
Badr G. Carlsson CA, Fall M, Friberg S, Lindström L, Ohisson B (1982) Cortical evoked potentials following stimulation of the urinary bladder in man. Electroencephalogr Clin Neurophysid 54 : $494-498$.

Badr G, Fall M, Carlsson CA, Linidström L, Friberg S, Ohisson B (1984) Cortical evoked potentials obtained after stimulation of the lower urinary tract. J Urall 131: 306-309.

Barlow JS (1957) An electronic method for detecting ewoked responses of the brain and for reproducing their average wave forms. Electroencephalogr Clin Neurophysiol 9: 340-343.

Barrington FJF (1914) The nervous mechanism of micturition. Q J Exp Physiol 8: 33-43.

Barrington FJF (1921) The relation of the hind brain to micturition. Brain 44: 23-53.

Bartley O, Brolin J, Fagerberg SE, Wilhelmsen L (1966) Neurogenic disorders of the bladder in diabetes mellitus. Acta Med Scand 180: 187-198.

Basmajian JV, Spring WB (1955) Electromyography of the male (voluntary) sphincter urethrae. Anat Rec 121: 388-392.

Beck A (1930) Elektromyographische Untersuchungen am Sphincter ani. Arch Physiol 224: 278-292.

Bell C (1972) Autonomous nervous control of reproduction: Circulatory and other factors. Pharmacol Rev 24: 657-671.

Bhatia NN, Bradley WE, Haldeman S (1982) Urodynamics: continuous monitoring. J Urol 128: 963-968.

Bertelsmann FW, Heimans $J_{\|}$Rooy JGGM, Visser SL (1986) Comparison of Hoffmann reflex with quantitative assessment of cutaneous sensation in diabetic neuropathy. Acta Neurol Scand 74: 121-127.

Birkhoff JD (1983) Natural history of benign prostatic hypertrophy. In: Hinman F ed Benign Prostatic Hypertrophy Springer, New York 5.

Bishop B (1959) Reflex activity of external anal sphincter of cat. J Physiol 137: 679-692.

Blaivas JG (1979) A critical appraisal of specific diagnostic techniques. In: Krane RJ, Siroky MD eds Clinicall Neuro-Urology Little Brown, Boston 69-109.

Blaivas JG, Labib KB (1976) Pitfalls in Urodynamic Diagnosis. Paper presented at the Annual Meeting of the New England Section of the American Urological Association held at Majorca, Spain.

Blaivas JG, Labib KB (1977) Acute urinary retention in women: Complete urodynamics evaluation. Urology 10: $383 \times 390$.

Bloom W, Fawcett DW (1962) A Textbook of Histology. Saunders, Philadielphia.

Bloom SR, Vaughan NJA, Russell RCG (1974) Vagal control of glucagon release in man. Lancet 7: 546-549.

Bors $E(1952)$ Effect of electric stimulation of the pudendal nerves on wesical neck. J Urol 67 : 925-935.

Bors $E$ (1957) Neurogenic bladder. Urol Surv 7: 177-182.

Bors E, Blinn KA (1957) Spinal reflex activity from the vesical mucosa in paraplegic patients. Arch Neurol Psychiatry 78: 339-354.

Bors EH, Blinn KA (1959) Bulbocavernosus reflex. J Urol 82: 128-132.

Bors EH, Comarr AE (1960) Neurological disturbances of sexual function with special reterences to 529 patients with spinall cord injury. Urol Surv 10: 191-222.

Bors EH, Comarr AE (1971) Neuro-anatomy and neurophysiology. In: Bors $\mathbb{E}$, Comarr A eds Neurological Urology Karger, Basel 61-125.

Bowen JIM, Timm GW, Bradley WE (1976) Some contractile and electrophysiological properties of the periurethral striated muscle of the cat. Invest Urol 13: 327-330. 
Bradley WE (1969) Regulation of the micturition reflex by negative feedback. J Urof 101: $400-402$.

Bradley WE (1972) Urethral electromyelography. J Urol 108: 563-564.

Bradley WE (1976) Cystometry and sphincter electromyography. Mayo Clin Proc 51: 329-335.

Bradley WE (1978) Innervation of the male urinary bladder. Urol Clin North Am 5: $279-293$.

Bradley WE (1980) Cerebro-cortical innervation of the urinary bladder. Tohoku J Exp Med 131: $7-13$.

Bradley WE (1980) Diagnosis of urinary bladder dyslunction in diabetes mellitus. Ann Intern Med 92: 323-326.

Bradley WE, Chou S, Markland $C$ (1967) Classifying neurologic dysfunction of the urinary bladder. In: Boyarsky $S$ ed The Neurogenic Bladder Williams, Baltimore 136-146.

Bradley WE, Rockswold GL, Timm GW, Scott FB (1976) Neurology of micturition. J Urol 115: $481-486$.

Bradley WE, Scott FB, Timm GW (1974) Sphincter electromyography. Urol Clin North Am 1: $69-80$.

Bradley WE, Sundin T (1982) The physiology and pharmacology of urinary tract dysfunction. Clin Neuropharmacol 5: 131-158.

Bradley WE, Teague CT (1968) Spinal cord arganization of micturition reflex afferents. Exp Neurol 22: 504-516.

Bradley WE, Teague CT (1968) Innervation of the detrusor muscle by the ganglia of the pelvic plexus. Invest Urol 6: 251-266.

Bradley WE, Teague CT (1972) Electrophysiology of pelvic and pudendal nerves in the cat. Exp Neurol 35: 368-393.

Bradley WE, Timm GW, Rockswold GL, Scott FB (1975) Detrusor and urethral electromyelography. J Urol 114: 891-894.

Bradley WE, Timm GW, Scott FB (1974) Innervation of the detrusor muscle and urethra. Urol Clin North Am 1: 3-27.

Bradley WE, Timm GW, Scott FB (1975) Cystometry II: Central nervous system arganization of detrusor reflex. Urology 5: 578-580.

Bradley WE, Timm GW, Scott FB (1975) Cystometry V: Bladder sensation. Urology 6: 643-648. de Bruim AJJ (1978) Medicamenteuze behandeling van urine incontinentie. In: de Bruin AJJ, Vereecken RL eds Urine Incontinentie bij Man en Vrouw Staflew, Leiden 204-218.

Buchthal F, Rosenfalck P (1954) Action potential parameters in normal human muscle. Acta Physiol Scand 32: 219-224.

Buck $A C$, Reed PI, Siddiq YK, Chisholm GD, Fraser TR (1976) Bladder dysfunction and neuropathy in diabetes. Diabetologia 12: 251-258.

Buez $E_{*}$ Alnor $P$, Peter $D(1957)$ Sexualfunctionstörungen nach lumbaler Grenzstrangresektion. Chirurg 28: 103-107.

Burnstock $G$ (1986) Non-adrenerg neurotransmitters in relation to sympathetic nerwous controll of the lower urinary tract. Clin Sci 70 Suppl 14: 15-20.

Campbell IW, Ewing DJ, Anderton ل JL, Thompson JH, Horne DB, Clarke BF (1976) Plasma renin activity in diabetic autonomic neuropathy. Eur $J$ Clin Invest $6: 381-385$.

Campbell JW, Heading RC, Tothill P, Buist TAS, Ewing DJ, Clarke BF (1977) Gastric emptying in diabetic autonomic neuropathy. Gut 18: 462-467.

Chantraine A, De Leval J, Onkelinx A (1973) Motor conduction velocity in the internal pudendal nerves. In: Desmedt JE ed New Developments in Electromyography and Clinical Neurophysiology Karger, Basel 433-438. 
Chantraine A, De Leval J, Onkelinx A (1973) Motor conduction velocity in the internal pudendal nerwes. In: Desmedt JE ed New Developments in Electromyography and Clinical Neurophysiology Karger, Basel $433-438$.

Chantraine A, Lloyd $K$, Swinyard ChA (1966) The sphincter ani externus in spina bifida and myelomeningocele. J Urol 95: 250-256.

Chou SM, Kuzuhara $S$, Nonaka l (1982) Inwolvement of the Onuf nucleus in Werdnig-Hoffmann disease. Neurology 32: 880-884.

Clarke BF, Ewing DJ, Campbell IW (1980) Clinical features of diabetic autonomic neuropathy. Horm Metab Res 9: 50-60.

Cole Nil (1981) Drugs causing sexual problems. Pharm Int 2: 63-67.

Colon EJ, Posthumus Meyjes FE (1983) Somatosensory evoked potentials. In: Collon EJ, Visser SL, de Weerd JP, Zonneveldt A eds Evoked Potential Manual Martinus Nijhoff, Bositon 245-319.

Comarr AE (1970) Sexual function among patients with spinal cord injury. Uroll Int 25: 134-168.

Cooke AR (1975) Control of gastric emptying and motility. Gastro-enterology 68: 804-816.

Coolsaet BLRA (1983) Ouder worden met de prostaatklier. Ned Tijdschr Geneeskd 46: 2094-2101.

Cusick JF Myiklebust JB, Larson SJ, Sances A (1979) Spinal cord evaluation by cortical evoked responses. Arch Neurol 36: 140-143.

Dawson GD (1947) Cerebral responses to electrical stimulation of peripheral nerve in man. J Neurol Neurosurg Psychiatry 10: 137-140.

Dawson GD (1950) Cerebral responses to nerve stimulation in man. Br Med Bull 6: 326-329.

DeGroat WC (1975) Nervous control of the urinary bladder of the cat. Brain Res 87: 201-203.

DeGroat WC, Booth AM (1984) Autonomic systems of the urinary bladder and sexual organs. In: Dijck PJ ed Peripheral Neuropathy Saunders, Philadelphia 285-299.

DeGroat WC, Lalley PM (1972) Reflex firing in the Iumbar sympathetic outflow to activation of vesical afferent fibers. J Physiol 226: 189-193.

Desmedt JE, Noel P (1973) Average cerebral evoked potentials in the evaluation of lesions of the sensory nerves and of the central somatosensory pathway. In: Desmedt JE ed New Developments in Electromyography and Clinical Neurophysiology Karger, Basel 352-371.

Dick HC, Bradley WE, Scott FB, Timm GW (1974) Pudendal sexual reflexes: Electrophysiologic Investiglations. Urology 3: 376-379.

Dolman CL (1963) The morbid anatomy of diabetic neuropathy. Neurology 13: 135-142.

Donker PJ, Droës JThPM, van Ulden BM (1976) Anatomy of the musculature and innervation of the bladder and the urethra. In: Williams, D Chisholm GD eds The Scientific Foundations of Urology Heidemann, London 32-38.

Doriman LJ (1977) Indirect estimation of spinal cord conduction velocity in man. Electroencephalogr Clin Neurophysiol 42: 26-34.

Ebensperger $H(1980)$ Somatosensorisch evozierte kortikale Potentiale nach elektrischer Stimulation des Nervus tibialis. Untersuchungen an Normalpersonen und an Patienten mit multipler Sklerose. Dissertation Tubingen

Eckhardt $\mathrm{C}$ (1863) Untersuchungen über die Erektion des Penis beim Hund. Beitr Anat Physiol 3: $123-127$.

Edvardsen $\mathrm{P}$ (1968) Nervous control of urinary bladder in cats: The collecting phase. Acta Physiol Scand 72: 157-165.

Edvardsen P, Setekleiv J (1968) Distribution of adrenergic receptors in the urinary bladder of cats, rabbits and guinea pigs. Acta Pharmacol Toxicol $26: 437-444$. 
Eisen A, Elleker G (1980) Sensory nerve stimulation and evoked cerebral potentials. Neturology 30. $1097 \cdot 1105$.

Eisen $A$, Odusote $K(1980)$ Central and peripheral conduction times in multiple sclerosis. Electroencephalogr Clin Neurophysiol 48: 253-265.

El Badawi $A$ schenck EA (1974) A new theory of the innervation of bladder musculature: Innervation of the vesicourethral junction and external urethral sphincter. J Urol 3: $613-620$.

Ellenberg M (1963) Diabetic complications without manifest diabettes. I Am Med Assoc 183 : 926.

Ellenberg M (1966) Diabetic neurogenic vesical dysfunction. Arch Intern Med 117: 348-354.

Ellenberg M (1971) Impotence in diabetes: The neurologic factor. Ann Intern Med 75: 213-219.

Ellenberg M (1980) Development of urinary bladder dysfunction in diabetes mellitus. Ann Intern Med 92: 321-323.

Ellenberg M (1982) Diabetic neuropathy. Compr Ther 8: 21.31.

Ellenberg M, Weber $H(1966)$ Retrograde ejaculation in diabetic neuropathy. Ann \|ntern Med 65: $1237-1246$.

Ellenberg $M$, Weber $H(1967)$ The incipient asymptomatic diabetic bladder. Diabetes 16 : 331-335.

Elliott TR (1907) The inmervation of the bladder and urethra. J Physiol 35: 367-445.

Ertekin $\mathrm{C}_{\text {, }}$ Akyürekli $\mathrm{O}$, Gurses AN, Turgut $\mathrm{H}$ (1985) The value of somatosensory evaked potentials and bulbocavernosus reflex in patients with impotence. Acta Neurol Scand 71: 48-53.

Ertekin $C_{n}$ Reel $F$ (1976) Bulbocavernosus reflex in normal men and in patients with neurogenic bladder and/or impotence. J Neurol Sci 28: 1-15.

Ewing DJ, Campbell IW, Burt AA, Clarke BF (1973) Vascular reflexes in diabetic autonomic neuropathy. Lancet 2: 1354-1356.

Ewing DJ, Campbell IW, Clarke BF (1976) Mortality in diabetic autonomic neuropathy. Lancet 1: $601-603$.

Ewing DJ, Irving JB, Kerr F, Wildsmith JAW, Clarke BF (1974) Cardiovascular responses to sustained handgrip in normal subjects and in patients with diabetes mellitus: A test of autonomic function. Clin Sci Mol Med 46: 295-306.

Faerman I, Faccio E, Milei J. Nunez R, Jadzinsky M, Fox D. Rapaport M (1977) Autonomic neuropathy and painless myocardial infarction in diabetic patients: Histologic evidence of theil" relationship. Diabetes 26: 1147-1158.

Faerman 1, Glocer L, Fox D, Jadzinsky M, Rapaport M (1974) limpotence and diabetes: Histological studies of the autonomic nervous fibers of the corpora cavernosa in impotent diabetic males. Diabetes 23: 971-977.

Faerman I, Maler M, Jadzinsky M, Alvarez E, Fox D Zilbervarg J, Cibeira JB, Collinas R (1971) Asymptomatic neurogenic bladder in juvenile diabetics. Diabetologia 7: 168-172.

Faermam I, Vilar O, Rivarola MA, Rosner JM, Jadzinsky MN, Fox D, Lioret AP, Bernstein-Hahn $L$, Saraceni $D(1972)$ Impotence and diabetes: Studies of androgenic function in diabetic impotent males. Diabietes 21: 23-30.

Fagerberg SE (1969) A study of the urinary bladider in diabetic malles and controls. In: Ostman $\mathrm{J}$ ed Proceedings $\mathrm{VI}$ Congress of International Diabetes Federation Excepta Medica, Amsterdam 666-667.

Fagerberg SE, Kock NG, Petersen II, Stener I (1967) Urinary bladder disturbances in diabetics: A comparative study of malie diabetics and controls aged between 20 and 50 years. Scand J Urol Nephrol 1: 19-27. 
Fidas A, Corcoran M, Galloway M!, Mcinnes A, Chisholm GD (1985) Latent neuropathology in idiopathic detrusor instability elicited by sacral evoked responses. In: Proceedings International Continence Society London 40-41.

Fletcher TF, Bradley WE (1978) Neuroanatomy of the bladder-urethra. J Urol 119: 153-160.

Fletcher TF, Hammer RF, Bradley WE (1969) Nerve endings in the urinary bladder of the cat. J Comp Neurol 136: No11.

Floyd WF, Walls EW (1953) Electromyography of the sphincter ani externus in man. J Physiol 122: $559-609$.

Fournier GR, Juenemamn KP, Lue TF, Tanagho EA (1987) Mechanisms of venous occiusion during canine penile erection: An anatomic demonstration. J Urol 137: 163-167.

Fowler J, Kirby RS, Harrison MJ (1985) Decelierating burst and complex repetitive discharges in the striated muscle of the urethral sphincter, associated with urinary retention in woman. J Neuroll Neurosurg Psychiatry 48: 1004-1009.

Friedman H, Nashold BS, Senechal P (1972) Spinal cord stimulation and bladder function in normal and paraplegic animals. I Neurosurg 36: 430-437.

Friedman SA, Freiberg $P$, Colton $J(1972)$ Vasomotor tone in diabetic neuropathy. Ann Intern Med 77: 353-356.

Frimodt-Meller $C$ (1972) A new method for quantitative evaluation of bladder sensitivity. Scand J Urol Nephrol (suppl) 15: 135-138.

Frimodt-Meller C (1976a) Diabetic cystopathy: A clinical study of the frequency of bladder dysfunction in diabetics. Dan Med Bull 23: 267-278.

Frimodt-Mølter C (1976b) Diabetic cystopathy: Relationship to some late-diabetic manifestations. Dan Med Bull 23: 279-287.

Frimodt-Møller C (1978) Diabetic cystopathy: A review of urodynamic and clinical features of neurogenic bladder dysfunction in diabetes mellitus. Dan Med Bull 25: 49-60.

Garland H (1955) Diabetic amyotrophy. Br Med J 26: 1287-1290.

Garland H (1960) Neurological complications of diabetes mellitus: Clinical aspects. Proc R Soc Med 53: 137-141.

Garland H, Taverner D (1953) Diabetic myelopathy. Br Med J 27: 1405-1408.

Genuth $S$ (1982) Classification and diagnosis of diabetes mellitus. Med Clin North Am 66: $1191-1207$.

Gerstenberg TG, Klarskov $P$, Hald $T$ (1985) Bulbocavernosus reflex measurement during cystometry predicts non-neurogenic detrusor overactivity. Proceedings International Continence Society London 111-113.

Girard $R_{1}$ Minaire $P$, Casteran JP, Berard E, Eyssette M (1978) Anal and urethral sphincter ellectromyography in spinal cord injured patients. Paraplegia 16: 244-247.

Goodman Jl (1966) Diabetic anhydrosis. Am J Med 41: 831-835.

Gosling JA (1979) The structure of the bladder and urethra in relation to function. Urol Clin North Am 6: 1-7.

Gosling JA (1985) Structure of the lower urinary tract and pelvic floor. Clin Obstet Gynaecol 12: $285-294$.

Greene LF, Kelalis PP; Weeks RE (1963) Retrograde ejaculation of semen due to diabetic neuropathy: Report of 4 cases. Fertil Sterill 14: 617-625.

Griggs DE, Olsen W (1937) Changes in the spinal cord in diabetes mellitus. Arch Neurol Psychiatry 38: 564-57\%.

Gunterberg B, Kewenter I, Petersen I, Stenar B (1976) Anorectal function after major resections of the sacrum with bilateral or unilateral sacrifice of sacral nerves. Br J Surg 63: 546-554. 
Gunterberg B. Petersen I (1976) Sexual function after major resection of the sacrum with bilateral sacrifice of sacral nerves. Fert Steril 27 : $1146-1153$.

Gupta PR, Dorfman LJ (1981) Spinal somatosensory conduction in diabetes. Neurology 31 : 841-845.

Habib HN (1963) Neural trigger points for evacuation of neurogenic bladder by electrostimulation. Surg Forum 14: 489-491.

Haldeman $S$, Bradley WE, Bhatia $N(1982)$ Evoked responses from the pudendal nerve. J Urol 128: $974-980$.

Haldeman S, Bradley WE, Bhatia N, Johnson BK (1982) Pudendal evoked responses. Arch Neurol 39: 280-283.

Haldeman $S$, Bradley W, Bhatia N, Ek A, Taylor M, Johnson BK (1982) Pudendal evoked responses in neurologic disease. Neurology 32: $67-74$.

Hamberger $B$, Norberg KA (1965) Adregenic synaptic terminals and nerve cells in bladder ganglia of the cat. Int $J$ Neuropharmacol $4: 41-45$.

Handwerker HO, Zimmerman M (1972) Cortical evoked responses upon stimulation of group III fibers and the mediating spinal pathways. Brain Res 36: 437-440.

Hauri D (1978) Post-prostatectomy incontinence. Urol Res 6: 113-118.

Henry MM, Parks AG, Swash M (1980) The anal reflex in idiopathic faecal incontinence: An electrophysical study. $\mathrm{Br} \mathrm{J}$ Surg 67 : 781-783.

Herrlinger A, Schrott KM (1978) Sympathikotone Kontinenztherapie der neurogenen Blase. Urologe 17: 349-352.

Hoffmann P (1919/1920) Demonstration eines Hemmungsreflexes im menschlichen Rückenmark. Z Biol 70: 515-524.

Hofman P (1969) Bladder and sfincter functions and their disorders. In: Vinkem PJ, Bruyn GW eds Handbook of Clinical Neurology North-Holland Publ, Amsterdam 1: 356-403.

Hogenhuis LAH, Clifford Rose F (1984) The classification of diabetic neuropathy. Neuroepidemiology 3: 169-189.

Hopkins WF, Pierce JM (1969) The neurogenic bladder in diabetes mellitus. In: Boyarsky S ed The Neurogenic Bladder Williams, Baltimore 155-165.

Hosking D.J, Bennett T, Hampton JA (1978) Diabetic autonomic neuropathy. Diabetes 27: $1043-1055$.

Howard 1, Schiff MD (1982) The neurogenic bladder in diabetes. Naw York State J Med 5 : 922-926.

Hume AL, Cant BR, Shaw NA, Cowan JC (1982) Central somatosensory conduction time from 10-79 years. Electroencephalogr Clin Neurophysiol 54: $49-54$.

Ingberg $\mathrm{HO}$, Johnson EW (1963) Electromyographic evaluation of infants with lumbar meningomyelocele. Arch Phys Med Rehabil 44:" 86-92.

loanid CP, Noica $N$, Pop T (1981) Incidence and diagnostic aspects of the bladder disorders in diabetics. Eur Urol 7: 211-214.

Ischi F, Isch-Treussard C, Ferrer-Ducaud $S$ (1962) Variations de l'amplitude respective des responses $M$ et $H$ en fonction des caractéristiques d'excitabilite des fibres nerveuses. Electroencephalogr Clin Neurophysiol 22: 95-97.

Jones SJ, Small DG (1978) Spinal and sub-corticall evaked potentials following stimulation of the posterior tibial nerve in man. Electroencephalogr Clin Neurophysiol 44: 299-306.

de Jonge MC (1976) Electromyography of the striated anal and urethral musculature in the investigation of the function of the lower urinary tract. In: Gool $\mathrm{J}$ ed Proceedings Nederlandse Vereniging voor Electro-encephalografie en Klinische Neurofysiologie 41: 436. 
Jordain WR, Crabtre HH (1935) Paralysis of the bladder in diabetic patients. Arch Intem Med 55: $17 \times 25$.

Kahan M, Goldberg PD, Mandel EE (1970) Neurogenic vesical dysfinction and diabetes mellitus. $N$ Y J Med 2: 2448-2455.

Kaplan PE (1981) A somatosensory evoked response obtained after stimulation of the contralateral pudendal merve: A prelimary report. Electromyogr Clin Neurophysiol 21: 585-587.

Karacan 1 (1970) Clinical value of nocturnal erection in the prognosis and diagnosis of impotence. Med Aspects of Human Sexuality 4: 27-34.

Kassiander P (1958) Asymptomatic gastric retention in diabetes: Gastroparesis diabeticorum. Anri Intern Med 48: 797-812.

Katz LA, Spiro HM (1966) Gastraintestinal manifestations of diabetes. New Engl J Med 275 : 1350-136t.

Kawakami M (1954) Electromyographic investigation of the human external sphincter muscle of anus. Jap $J$ Physiol 4: 196-201.

Kedia $\mathrm{KP}_{n}$ Markland $\mathrm{C}$, Fraley EE (1975) Sexual function following high retroperitoneal lumphadenectomy. I Urol 114: 237-241.

Khanna OP. Heber D, Gonick P' (1975) Cholinergic and adrenergic neuroreceptors in urinary tract of female dogs: Evaluation of function with pharmacodynamics. Urology 5: 616-620.

Kimche D, Saar M, Lask D (1985) Evoked response studies in detrusor hyperreflexia due to infravesical obstruction in neurological patients. J Urol 133: 641-643.

Kimura $\mathrm{J}(1985)$ Abuse and misuse of evoked potentials as a diagnostic test. Arch Neurol 42 : 78-80.

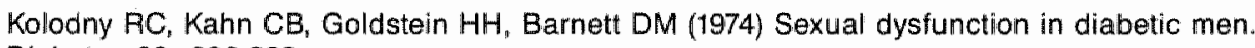
Diabetes 23: 306-309.

Kott E, Bechar M, Bornstein B (1971) Demyelination of the posterior and anterior columns of the spinal cord in association with metabolic disturbances. Isr $\mathrm{J}$ Med Sci 7: 577-580.

Krane RJ, Siroky MB (1979) Classification of neurological disorders. In: Krane RJ, Siroky MB eds Clinical Neuro-Urology Little Brown, Boston 143-158.

Krane R.J, Siroky MB (1980) Studies on sacral-evoked potentials. J Urol 124: 872-876.

Kuru M (1965) Nervous control of micturition. Physiol Rev 45: 425-494.

Langworthy OR, Reeves DL, Tauber ES (1934) Autonomic control of the urinary bladder. Brain 57: $266-290$.

Lapides J, Ajemian EP, Stewart BH, Breaky BA, Lichtwardt JR (1960) Further observations on the kinetics of the urethrovesical sphincter. J Ural 84: 86-94.

Lapides J, Bobbitt JM (1956) Diagnostic value of bulbocavernosus reflex. J A M A 162: 971-973.

Lapides J. Sweet RB, Lewis LW (1957) Role of striated muscle in urination. J Urol 77: 247-250.

Larcan A, Huriet G, Vaillandet M. Fauchier JP (1965) Les manifestations vesicales au course du diabete. Presse Med 75: 273-276.

Learmonth JR (1931) A contribution to the neurophysiology of the urinary bladder in man. Brain 54: $147-176$.

Leval-Picquechef L (1885) Des Pseudotabes. These de Paris (Lille: Imprimerie Desclée de Brouwer et $\mathrm{Cie}$ ).

Lich $R$, Grant $O$ (1948) Vesical abnormalities incident to diabetes mellitus. J Ural 59: 863-871.

Liu CN, Chambers WW (1958) Intraspinal sprouting of dorsal roat axons: Development of new collaterals and preterminals following partial denervation of the spinal cord in the cat. Arch Neurol Psychiatry 79: 46-51. 
Logothetis J, Baiker AB (1963) Neurologic manifestations in diabetes mellitus. Med Clin North Am 47: 1459-1466.

Low PA, Walsh JC, Huang CY, MCLeod JG (1975a) The sympathetic nervous system in diabetic neuropathy: A clinical and pathological study. Brain 98: 341-350.

Low PA, Walsh JC, Huang CY, MCLeod JG (1975b) The sympathetic nervous system in alcoholic neuropathy: A clinical and pathological study. Brain 98: 357.365 .

Lue TF, Tanagho EA (1987) Physiology of erection and pharmacological management of impotence. U Urol 137: 829-836.

Lytton B, Emery JM, Haward BM (1968) The incidence of benign prostatic obstruction. J Urol 99: 639-645.

Mannen T (1966) Vascular lesions in the spinal cord in the aged: A clinico pathological study. Geriatrics 21:: 151-160.

Manning NT, Ireland J (1981) Urological aspects of diabetes. Int Rehabil Med 4: $52-54$.

Markland C, Merrill D, Chou S, Bradley W (1972) Sacral nerve root stimulation: A clinical test of detrusor innervation. J Urol 107: $772-776$.

Marsden CD, Merton PA, Morton HB (1982) The latency of the anal reflex. J Neurol Neurosurg Psychiatry 45: 857-863.

Martin MM (1953) Involvement of autonomic nerve fibers in diabetic neuropathy. Lancet 1: $560-565$.

Martin WD, Fletcher TF, Bradley WE (1974) Innervation of feline perineal musculature. Anat Rec 180: $15-30$.

Mayer RF, Mawdsley C (1965) Studies in man and cat of the significance of the $H$ wave. $\checkmark$ Neurol Neurosurg Psychiatry 28: 201-211.

McGuire EJ (1986) The innervation and function of the lower urinary tract. J Neurosurg 65: 278-285.

McLean PD, Ploog DW (1962) Cerebral representation of penile erection. J Neurophysiol 25: 29-33.

McLeod JG (1958) The representation of the splanchnic afferent pathways in the thalamus of the cat. J Physiol 140: 462-468.

Morales O, Romanus R (1953) Urethrography in the male. Acta Radiol 39: 454-476.

Motzkin D (1968) The significance of deficient bladder sensation. J Uroll 100: 445-450.

Namerow NS (1968) Somatosensory evoked responses in multiple sclerosis patients with varying sensory loss. Neurology 18: 1197-1204.

Nathan PW (1952) Micturition reflexes in man. J Neurol Neurosurg Psychiatry 15: 148-149.

Nathan PW (1956a) Awareness of bladder filling with divided sensory tract. J Neurall Neurosurg Psychiatry 19: 101-105.

Nathan PW (1956b) Sensations associated with micturition. Br J Urol 28: 126-131.

Nathan PW, Smith MC (1951) The centripetal pathway from the bladder and urethra within the spinal cord. I Neurol Neurosurg Psychiatry 14: 262-280.

Nergardh A, Boreus LO (1972) Autonomic receptorfunction in the lower urinary tract of man and cat. Scand J Urol Nephrol 6: 32-36.

Newman HF, Northup JD, Devlin J (1964) Mechanism of human penile erection. Invest Uroil 1 : 350-353.

Nonne M (1896) Uber Poliomyelitis anterior chronica als Ursache einer chronisch-progressiven atrophischen Lämung bei Diabetes Mellitus. Berl Klin Wochenschr 33: 207-212. 
Nording $J_{\text {, Meyhoff } H} \mathrm{H}$. Olesen KP (1982) Cysto-urethrographic appearance of the bladder and posterior urethra in neuromuscular disorders of the lower urinary tract. Scand J Urol Nephrol 16: 115-124.

Notermans SLH, Spiertz M, Vingerhoets HM, Nobel de $E$ (1977) The significance of the measuremert of the $H$ reflex as early detection of polyneuropathy in diabetic patients. In: Proceedings XI International Congress Neuralogy Excepta Medica, Amsterdam 325.

Notermans SLH, Vingerhoets HM (1974) The importance of the Hoffman reflex in the diagnosis of lumbar root lesions. Clin Neurol Neurosurg 1: 54-65.

Odel HM, Foth GM, Keating FR (1955) Autonomic neuropathy stimulating the effects of sympathectomy as a complication of diabetes mallitus. Diabetes 4: $92-98$.

Oliver JE, Bradley WE, Fletcher TF (1969) Identification of preganglionic parasympathetic neurons in the sacral spinal cord of the cat. J Comp Neurol 137: 321-328.

Oliver JE, Bradley WE, Fletcher TF (1969) Spinal cord representation of the micturition reflex. J Comp Neurol 137: 329-346.

Oliver JE, Bradley WE, Fletcher TF (1970) Spinal cord distribution of the somatic innervation of the external urethral sphincter of the cat. J Neurol Sci 10: 11-23.

Onuf $B(1901)$ On the arrangement and function of the cell groups of sacral region of the spinal cord in man. Arch Neurol Psychopathol 3: 387-412.

Opsomer $\mathrm{A}_{\mathrm{J}}$, Top $\mathrm{M}_{\mathrm{v}}$ Wesi FX, van Caugh PJ (1985) Cerebral evoked potentials from the pudendal nerve. In: Proceedings International Continence Society, London 38-39.

Page M, Watkins PJ (1976) Provocation of posturnal hypotension by insulin in diabetes autonomic neuropathy. Diabetes 25: 90-95.

Patton HD (1960) Taste, olfaction and visceral sensation. In: Ruch TC, Fulton JF eds Medical Physiology and Biophysics Saunders, Philadelphia 369-385.

Pedersen E (1978) Electromyagraphy of the sphincter muscles. Electroencephalogr Clin Neurophysil 34: 405-416.

Pedersen $E_{\text {" Harving }} H_{\text {, Klemar }} \mathrm{B}_{n}$ Törring $J(1978)$ Human anal reflexes. J Neurol Neurosurg Psychiatry 41: 813-818.

Pedersen $E$, Klemar B, Schröder $\downarrow$, Töring $J(1982)$ Anal sphincter responses after perianal electrical stimulation. I Neurol Neurosurg Psychiatry 45: 770-773.

Pedersen E, Töring J, Klemar B (1982) Reflex connections between the pelvic sphincters, the urinary bladder and the legs. Acta Neurol Scand 65: 225-229.

Percy JP, Neill M, Parks A, Swash M (1981) Electrophysiological study of motor nerve supply of pelvic floor. Lancet 1: $16-17$.

Petersen I, Franksson C (1955) Electromyographic study of the striated muscles of the male urethra. $\mathrm{Br} J$ Urol 27: 148-153.

Petersen I, Stener I (1970) An electromyographical study of the striated urethral sphincter, the striated anal sphincter and the levator ani muscle during ejaculation. Electromyogr $10: 23-44$.

Pirart I (1965) Diabetic neuropathy: A metabolic or a vascular disease? Diabetes $14: 1-9$.

Plum F, Colfeld RH (1960) The genesis of vesical rhytmicity. Arch Neurol Psychiatry 2: 487-496

Pompeius $R$ (1966) Detrusor inhibition induced from anal region in man. Acta Chir Scand: Suppl 361.

Post EJ, McLeod JG (1977a) Acrylamide autonomic neuropathy in the cat: Neurophysiological and histological studies. I Neurol Sci 33: 353-359.

Pryce T (1893) On diabetic neuritis, with a clinical and pathological description of three cases of diabetic pseudotabes. Brain 16: 416-424.

Ranson SW, Billingsley PR (1918b) An experimental analysis of the sympathetic trunk and greater splanchnic nerve in the cat. J Comp Neurol 29: 441-447. 
Rattner $H$, Gerlaugh RL, Murphy $\rfloor J$, Erdman WJ (1958) The bulbocavernosus reflex. Electromyographic study of normal patients. J Urol 80: 140\%141.

Renshaw B (1941) Influence of discharge on motoneurons upon excitations of neighbouring motoneurons. I Neurophysiol 4: 167-183.

Retief PJM (1950) Physiology of micturition and ejaculation. South Afric Med J 24: $509-512$.

Riedel $H$ (1965) Systematische morphologische Untersuchungen am Rückenmark von Diabetikern. Zentralbl Allg Pathol 107: 506-513.

Rockswold GL, Bradley WE (1977) The use of evoked electromyographic responses in diagnosing lesions of the cauda equina. J Urol 118: 629-631.

Rockswold GL, Bradley WE, Timm GW, Chou SN (1976) Electrophysiological technique for evaluating lesions of the conus medullaris and cauda equina. J Neurosurg 45: 321-326.

Rose SS (1953) An investigation into sterility after lumbar ganglionectomy. $\mathrm{Br}$ Med J 31: $247-250$.

Rubin A, Babbott D (1958) Impotence and diabetes mellitus. J A M A 168: 498-500.

Rundles RW (1945) Diabetic neuropathy: General review with report of 125 cases. Medicine 24: $111-160$.

Rundles RW (1950) Diabetic neuropathy. Bull $N$ Y Acard Med 26: 598-616.

Rushworth $G$ (1967) Diagnostic value of the electromyographic study of reflex activity in man. In: Widen $L$ ed Recent Advances in Clinical Neurophysiology. Electroencephalogr Clin Neuraphysiol 25: 65-73.

Ruskim AP (1970) Anal sphincter electromyography. Electromyogr 10: 425-428.

Ruskin AP, Davis JE (1969) Anal sphincter electromyography. Electroencephalogr Clin Neurophysiol 27: 713-722.

Salama Benarroch I, Scorticatti CH, Rubinstein Salama A, Pagliere H, Cartelli E (1979) Study of bladder function in patients with prediabetes, latent diabetes, recent onset diabetes and juvenile diabetes. Acta Diabetol Lat 16: 211-218.

Sarnowski RJ, Cracco RQ, Vogel HB (1975) Spinal evoked responses in the cat. J Neurosurg 43: $329-335$.

Schneider RJ, Kulics AT, Ducker TB (1977) Proprioceptive pathways of the spinal cord. J Neurol Neurosurg Psychiatry 40: 417-433.

Schlyvitsch B, Kosintzew A (1939) Uber die Morphologie der Rami viscerales Plexus pudend (Nn Pelvici) beim Menschen. Z Anat Entw Gesch 109: 423-442.

Schöffling $A$, Federlin K, Ditschuneit $H$, Pfeiffer $E$ (1963) Disorders of sexual function in male diabetics. Diabetes 12: $519-527$.

Schröder HD (1981) Onuf"s nucleus X: A morphological study of a human spinal nucleus. Anat Embryol 162: 433-453.

Schuster MM (1968) Motor action of rectum and anal sphincters in continence and defecation. In: Code CF ed Handbook of Physiology American Physiological Society, Washington 2121-2140.

Scott FB, Quesada EM, Cardus D (1967) The use of combined uroflowmetry, cystometry and electromyography in evaluation of neurogenic bladder dysfunction. In: Boyarsky $S$ ed The Neurogenic Bladder Williams, Baltimore 106-116.

Semans $\mathrm{JH}_{\text {, Langworthy }} \mathrm{OR}$ (1938) Observations on the neurophysiology of sexual function in the male cat. J Urol $40: 836-846$.

Sherrington CS (1892) Notes on the arrangernent of some motor fibers in the lumbo-sacrall plexus. لJ Physiol 13: 676.

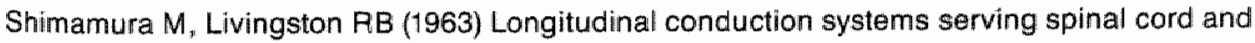
brainstem coördination. J Neurophysiol 26: 258-272. 
Siroky MB, Sax DS, Krane RJ (1978) Sacral signal tracing: The electrophysiology of the bubocavenosus reflew. J Urol 122; 661-664.

Sjöstrand NO (1962) Inhibition by ganglionic blocking agents of the motor response of the isolated guinea pig vas deferens to hypogastric nerve stimulation. Acta Physiol Scand 54: 306-315.

Sjöstrand NO (1965) The adrenergic innervation of the vas deferens and the accesory genital glands. Acta Physiol Scand 65: 257-260.

Slager U (1978) Diabetic myelopathy. Arch Pathol Lab Med 102: 467-469.

Slager U, Webb A, Downey $C$ (1973) Pathologic findings in the spinal cord. Arch Pathol 96: 388-394.

Smith CK, Engel LP (1932) Neurogenic vesical dysfunction in children. J Urol 28: 675-680.

Smith SE, Smith SA, Brown PM, Fox C, Sonksen PH (1978) Pupillary signs in diabetic autonomic neuropathy. $\mathrm{Br}$ Med J 11: 924-927.

Spencer PS, Schaumberg HH (1976) Central-peripheral distal axonopathy: The pathology of dying-back polyneuropathies. Prog Neuropathol 3: 253-295.

Stöhr M (1982) Somatosensibele Reizantworten von Rückenmark und Gehirn (SEP). In: Stöhr $M$. Dichgans J Diener HC, Buettner UW eds Evozierte Potentiale Springer, Berlin 17-215.

Stuart DG, Portner RW, Adey WR, Kamikawa Y (1964) Hypothalamic unit activity: Visceral and somatic influences. Electroencephalogr Clin Neurophysiol 16: 237-241.

Sundin T, Dahlström A, Norlen L, Svedmyr $\mathbb{N}$ (1977) The sympathetic innervation and adrenoreceptor function of the human lower urinary tract in the normal state and after parasympathetic denervation. Invest Urol 14: 322-328.

Sussman KE, Crout JR, Marble A (1963) Failure of warning in insulin-induced hypoglemic reaction. Diabetes 12: 38-45.

Swaab LI (1977) Autonome innervatie en vruchtbaarheid van de man: Een onderontwikkeld gebied van fertiliteitsonderzoek. I. Ned Tijdschr Geneeskd 26: 1011-1023.

Swaab LI (1977) Autonome innervatie en vruchtbaarheid van de man: een onderontwikkeld gebied van fertiliteitsonderzoek II. Ned Tijdschr Geneeskd 26: 1046-1051.

Swaiman KF, Bradley WE (1967) Quantitation of collagen in the wall of the human urinary bladder. $₫$ Appl Physiol 22: 122-127.

Swash M (1982) Early and late components in the human anal reflex. J Neurol Neurosurg Psychiatry 45: 767-769.

Swedin $G$ (1971) Studies on neurotransmission mechanisms in the rat and guinea pig vas deferens. Acta Physiol Scand: Suppl 369.

Talaat $M$ (1937) Afferent impulses in the nerves supplying the urinary bladder. J Physiol 89: $1-13$.

Tanagho EA, Smith DR (1968) Mechanism of urinary continence: Embryologic, anatomic and pathologic considerations. J Ulrol 100: 640-643.

Tang PC. Fuch TC (1956) Lacalization of brain stem and diencephalic areas controlling the micturition reflex. J Comp Neurol 106: 213-219.

Tarabulcy E (1972) Sexual function in the normal and paraplegia. Paraplegia 10: 201-208.

Taverner D. Smiddy FG (1959) An electromyographic study of the normal function of the external anal sphincter and pelvic diaphragm. Dis Colon Rectum 2: 153-160.

Treusch JV (1945) Diabetic neuritis: A tentative working classification. Proc Mayo Clin 20 : 393-402.

Trojaborg $W_{\text {s }}$ Petersen E (1979) Visual and somatosensory evoked cortical potentials in multiple sclerosis. J Neurol Neurosurg Psychiatry 42: 323-330. 
Tronteli d, Stolberg $\mathbb{E}$ (1983) Bizarre repetitive discharges recorded with singel fibre EMG. J Neurol Neurosurg Psychiatry 46: 310-316.

Trontelj MA, Trontelj JV (1978) Reftex arc of the first component of the human blink reflex: A single motoneurone study. J Neurol Neurosurg Psychiatry 41: 583-587.

Tsumoto $T$, Hirose $\mathbb{N}_{n}$ Nonaka $S$, Takahashi $M$ (1972) Analysis of somatosensory evolked potentialls to lateral popliteal nerve stimulation in man. Electroencephalogr Clin Neurophysiol 33: $379-388$.

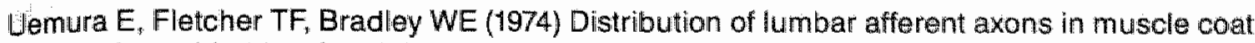
of cat urinary bladder. Am J Anat 139: 389-392.

Uemura $E$, Fletcher TF, Bradley WE (1975) Distributin of lumbar and sacral afferent axons in submucosa of cat urinary bladder. Anat Rec 183: 579-584.

Ulden v BM (1975) De musculatuur van de blaashals urethra posterior bij de man. Thesis, Leiden.

Uttal WR, Cook $L$ (1964) Systematics of the evoked somatosensory cortical potential: A psychophysilcal-electro-physiological comparison. Ann N Y Acad Sci 112: 60-80.

Vacek J, Lachman M (1977) Bulbocavernosus reflex in diabetics with erectivity disorders: Clinical and electromyographical study. Cas Lek Cisk 133: 1015.

Venema PL, Kramer AEL (1984) De klinische betekenis van het urodynamische onderzoek van de lagere urinewegen bij de man. Ned Tijdschr Geneeskd 128: 908-916.

Ventura WP, Freund M, Davis $\mathrm{J}(1973)$ Influence of norepimephrine on the motility of the human vas deferens: A new hypothesis of sperm transport by the vas deferens. Fertil Steril 24: 68-78.

Vereecken RL (1978) De neurogene blaas. In: de Bruin AJJ, Vereecken RL eds Urine Incontinentie bij Man en Vrouw Stafleu, Leiden 77-98.

Vereecken RL, De Meirsman J, Puers B, Van Mulders J (1981) Electrophysiological exploration of the sacral conus. Phys Med Electromyogr 12: 1-11.

Vereecken RL, Puers B, Van Mulders J (1982) Spectral analysis of perineal muscles EMG. Electromyogr Clin Neurophysiol 22: 321-326.

Vereecken $R L$, Verduyn $H(1970)$ The electrical activity of the paraurethral and perineal muscle in normal and pathological conditions. $\mathrm{Br} \|$ Urol 42: 457-463.

Verkuyl A (1976) Sexual function in paraplegia and tetraplegia. In: Vinken PJ, Bruyn GW eds Handbook of Clinical Neurology North-Holland Publ, Amsterdam 26: 437-461.

Vignoli GCMD (1978) Premature ejaculation: New electrophysiologic approach. Urology 11 : $81-82$.

Visser SL (1981) Reflexen. In: Notermans SL ed Klnische Elektromyografie Stafleu, Alphen aan de Rijn 353-368.

Visser SL, Zonneveldt A, de Rijke W, Don JA, Martens EIF, Stam D (1983) Normal Hoffmann reflex latencies (H-M interval) in relation to age and body length. Clin Neurol Neurosurg 85: 85-91.

Vodusek DB, Janko M, Lokar J (1983) Direct and reflex responses in perineal muscles on electrical stimulation. J Neural Neurosurg Psychiatry 46: 67-71.

Von Noorden C (1903) Die Zuckerkrankheit und ihre Behandlung. August Hirschwald, Berlin.

Vredeveld JW (1985) Somatosensory evoked potentials (Median nerve stimulation) in acute stroke. Thesis.

Wager EW, Buerger AA (1974) H-reflex latency and sensory conduction velocity in normal and diabetic subjects. Arch Phys Med 55: 126-129.

Wager EW, Buerger AA (1974) A linear relationship between H-reflex latency and sensory motor conduction velocity of posterior tibial nerves and clinical signs of neuropathy in diabetic subjects. Neurology (Minneap) 24: 711-714. 
Wall PO (1970) The sensory and motor role of impulses traveling in the dorsal columns towards the cerebral cortex. Brain 93: 505-524.

Watkins PJ (1973) Facial sweating after food: A new sign of diabetic autonomic neuropathy. Br Med $₫ 1: 583-587$.

Waylonis GW, Powers $J \Downarrow$ (1972) Clinical application of anal sphincter electromyography. Surg Clin North Am 52: 807-815.

de Weerd JPC Thijssen JM, Eggermont JJ (1981) Technische aspecten van evoked potential metingen. In: Visser $S \mathrm{~L}$, Zonneveldt $\mathrm{A}_{\mathrm{t}}$ Colon $\mathrm{EJ}$ eds Nascholingscursus Evoked Potentials, Amsterdam 1-15.

Willamsan RT (1894) Changes in the posterior collumns of the spinal cord in diabetes mellitus. Br Med J 1: 398-399.

Woltman W, Wilder RM (1929) Diabetes mellitus, pathologic changes in the spinal cord and peripheral nerves. Arch Intern Med 44: 567-603.

Woodburne RT (1964) Anatomy of the ureterovesical junction. J Ural (Baltimore) 92: 431-435. Wunderlich $M$. Swash $M(1983)$ The overlapping innervation of the two sides of the external anal sphincter by the pudendal nerves. J Neurol Sci 59: 97-109.

Wijndaele $J J$, De Sij WA (1980) Een klinische behandeling van de neurogene blaas. Ned Tijdschr Geneeskd 36: 213-218.

Yalla SV "Di Benedetto M, Blunt KJ, Sethi JM, Fam BA (1978) Urethral striated sphincter responses to electrobulbocavernosus stimulation. J Urol 119: 406-409. 


\section{APPENDICES}

APPENDIX 7.1.2.

Tabel 7.7

Latentietijden van reflexen en evoked potentials bij diabeticl zonder en met incontinentie (Gemiddelden en standaarddeviaties in $\mathrm{ms}$ )

\begin{tabular}{|c|c|c|}
\hline stress incontinentie & urge incontinentie & geen incontinenti \\
\hline N gemiddelde & $\begin{array}{l}N \text { gemiddelde } \\
\text { (SD) }\end{array}$ & $\begin{array}{l}\text { gemiddelde } \\
\text { (SD) }\end{array}$ \\
\hline
\end{tabular}

VAR m. sph.

ani ext.

$572,0(8,4)$

$2876,0(15,5)$

$4473,4(14,1)$

BCR I m. sph.

ani ext.

$5 \quad 32,8(4,8)$

$29 \quad 39,4(11,9)$

$45 \quad 38,4(9,6)$

BCR II m. sph.

ani ext.

$575,0(11,2)$

$27 \quad 79,9(20,0)$

$4578,2(11,4)$

PEP

$543,0(11,3)$

$29 \quad 42,9(4,5)$

$4544,8(6,0)$

PHEP

$466,0(7,8)$

$1076,6(16,0)$

$2571,0(22,8)$

Er werden geen significante verschillen tussen de gemiddelden gevonden.

De patienten met stress incontinentie zijn allen vrouwen.

Tabel 7.8

Latentietijien van reflexen en evoked potentials bij diabetici met intacte en met ontbrekende mictiedrang (Gemiddelden en standaarddeviaties in ms)

\begin{tabular}{|c|c|c|c|}
\hline \multicolumn{2}{|c|}{ intacte mictiedrang } & \multicolumn{2}{|c|}{ geen mictiedrang } \\
\hline N & $\begin{array}{l}\text { gemiddelde } \\
\text { (SD) }\end{array}$ & $\mathbb{N}$ & $\begin{array}{l}\text { gemididelde } \\
\text { (SD) }\end{array}$ \\
\hline 4 & $72,9(14,3)$ & 13 & $81,0(12,7) *$ \\
\hline & $37,2(8,9)$ & 14 & $44,1(14,1) *$ \\
\hline & $77,9(14,8)$ & 13 & $82,0(15,0)$ \\
\hline & $43,7(6,1)$ & 14 & $45,5(5,3)$ \\
\hline & $71,3(20,4)$ & 4 & $77,5(19,1)$ \\
\hline
\end{tabular}

${ }^{*} P<0,05$ 
Latentietijden van reflexen en evoked potentials bij diabetici met intact en met afwezig passagegevoel bil de mictie (Gemiddelden en standaarddeviaties in $\mathrm{ms}$ )

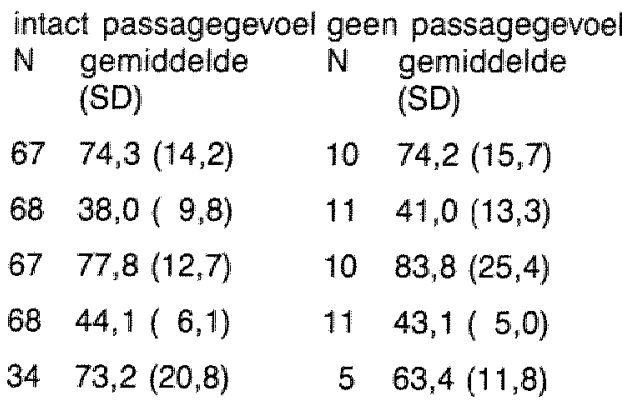

Er werden geen significante verschillen tussen de gemiddelden gevonden.

\section{Tabel 7.10}

Latentietijden van reflexen en evoked potentials bij diabetici met intact en met afwezig blaasledigingsgevoel (Gemiddelden en standaarddeviaties in ms')

$\begin{array}{lll}\begin{array}{l}\text { intact blaas- } \\ \text { ledigingsgevoel }\end{array} & \begin{array}{l}\text { geen blaas- } \\ \text { ledigingsgevoel }\end{array} & \begin{array}{l}\text { blaasledigingsgev } \\ \text { onbekend }\end{array} \\ \mathrm{N} \quad \begin{array}{l}\text { gemiddelde } \\ \text { (SD) }\end{array} & \mathrm{N} \begin{array}{l}\text { gemiddelde } \\ \text { (SD) }\end{array} & \mathrm{N} \text { gemiddelde }\end{array}$

VAR m. sph.

ani ext.

$66 \quad 74,8(14,6)$

$1072,9(10,7) \quad 1 \quad 50,0$

BCR I m. sph. ani

ext.

$66 \quad 37,6(8,6)$

$1241,4(16,8)$

153,0

BCA II m. sph.

ani ext.

PEP

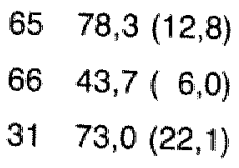

$1174,9(16,2)$

1137,0

PHEP

$$
3173,0(22,11)
$$

$1245,8(6,2)$

142,0

Er werden geen significante verschillen tussen de gemiddelden gevonden. 
Latentietijden van refiexen en evoked potentials bij diabetici met intact en met ontbrekend libido (Gemiddelden en standaarddeviaties in $\mathrm{ms}$ )

\begin{tabular}{|c|c|c|}
\hline intact libido & geen libido & libido onbekend \\
\hline $\begin{array}{l}N \text { gemiddelde } \\
\text { (SD) }\end{array}$ & $\begin{array}{l}\text { gemiddelde } \\
\text { (SD) }\end{array}$ & $\begin{array}{l}\text { gemiddelde } \\
\text { (SD) }\end{array}$ \\
\hline
\end{tabular}

VAR m. sph.

ani ext.

$4673,5(13,3)$

$9 \quad 72,9(15,0)$

$2276,4(16,3)$

BCR $\mathrm{m}$ sph.

ani ext.

$45 \quad 37,4(6,3)$

$9 \quad 34,0(7,4)$

$25 \quad 41,7(15,3)$

$\mathrm{BCR} \| \mathrm{m}$. sph.

ani ext.

$44 \quad 77,5(12,0)$

$978,2(14,2)$

$2480,8(9,4)$

PEP

$45 \quad 43,1(4,3)$

$9 \quad 42,7(4,9)$

$2546,1(8,2)$ *

PHEP

$2369,0(20,8)$

$365,3(13,7)$

$1378,8(19,4)$

* $P<0,05$ ( libido intact - onbekend)

Tabel 7.12

Latentietijden van reflexen en evoked potentials bij diabetici met intacte en met afwezige erectie (Gemiddelden en standaarddeviaties in ms)

$\begin{array}{lll}\text { intacte erectie } & \text { geen erectie } & \text { erectie onbekend } \\ N \begin{array}{l}\text { gemiddelde } \\ \text { (SD) }\end{array} & N \begin{array}{l}\text { gemiddelde } \\ \text { (SD) }\end{array} & N \text { gemiddelde }\end{array}$

VAR m. sph.

ani ext.

$\# 1 \quad 72,8(13,7)$

$2174,5(16,4)$

270,0

BCA $\| \mathrm{m}$. sph.

ani ext.

$10 \quad 39,5(9,0)$

$21 \quad 36,9(5,5)$

230,0

BCR \|l m. sph.

ani ext.

$\begin{array}{rrrrrr}9 & 77,2(12,3) & 21 & 77,9(10,1) & 2 & 72,5 \\ 11 & 45,2(5,7) & 20 & 45,1(2,6) & 2 & 47,5 \\ 5 & 57,8(8,0) & 12 & 68,6(15,3) & 2 & 80,0\end{array}$

PEP

PHEP

$5 \quad 57,8(8,0)$

$1268,6(15,3)$

280,0

Er werden geen significante verschillen tussen de gemiddelden gevonden. 
Letentietiden van reflexen en evoked potentials bij diabetici met intacte en met afwezige ejaculatie (Gemiddelden en standaarddeviaties in $\mathrm{ms}$ )

\begin{tabular}{lll} 
intacte ejaculatie & geen ejaculatie & \multicolumn{2}{c}{ ejaculatie onbekend } \\
$N$ gemiddelde & $N$ gemiddelde & $N$ gemiddelde \\
(SD) & & (SD)
\end{tabular}

VAR m. sph.

ani ext.

$2272,5(15,2) \quad 10 \quad 77,0(16,0) \quad 2 \quad 70,0$

BCR I m. sph.

ani ext.

$2136,5(7,2)$

$1040,3(5,2)$

230,0

BCR II m. sph.

ani ext.

$2074,8(10,3)$

$1083,6(8,9) * 272,5$

PEP

$22 \quad 44,9(4,2)$

$945,8(3,2) \quad 2 \quad 47,5$

PHEP

$\$ 467,3(14,0)$

$356,7(14,6)$

280,0

* $P<0,05$

Tabel 7.14

Latentietijden van reflexen en evoked potentials bij diabetici met aanwezig en met ontbrekend

orgasme (Gemiddelden en standaarddeviaties in ms)

\begin{tabular}{|c|c|c|}
\hline aanwezig orgasme & geen orgasme & orgasme onbeken \\
\hline $\begin{array}{l}\text { N gemiddelde } \\
\text { (SD) }\end{array}$ & $\begin{array}{l}\text { N gemiddelde } \\
\text { (SD) }\end{array}$ & $\begin{array}{l}\text { gemiddelde } \\
\text { (SD) }\end{array}$ \\
\hline
\end{tabular}

VAR m. sph.

ani ext.

$4073,3(13,6)$

$1475,1(12,7)$

$2375,4(16,6)$

BCR $\mid \mathrm{m}$. sph.

ani ext.

$39 \quad 36,9(6,2)$

$14 \quad 37,4(7,2)$

$2641,1(15,2)$

BCR $11 \mathrm{~m}$. sph.

ani ext.

$38 \quad 77,0(1,, 9)$

$1480,9(12,1)$

$25 \quad 79,8(19,8)$

PEP

$40 \quad 43,3(4,3)$

$1342,6(4,8)$

$2645,8(8,1)$ *

PHEP

22. $70,0(20,6)$

$460,2(15,1)$

$1378,8(19,4)$

* $P<0,05$ (orgasme aanwezig - onbekend) 
Latentietijden van reflexen en evoked potentials bij diabetici met een hypotone, normale en hypertone detrusor, zonder infravesicale obstructie (Gemiddelden en standaarddeviaties in ms)

\begin{tabular}{|c|c|c|}
\hline hypotoon & normaal & hypertoon \\
\hline $\begin{array}{l}\text { N gemiddelde } \\
\text { (SD) }\end{array}$ & $\begin{array}{l}\text { gemiddelde } \\
\text { (SD) }\end{array}$ & $\begin{array}{l}\text { gemiddelde } \\
\text { (SD) }\end{array}$ \\
\hline
\end{tabular}

VAR m. sph.

ani ext.

$1573,3(11,6)$

$38 \quad 72,4(13,9)$

$1278,3(18,7)$

BCR I m. sph.

ani ext.

$1538,5(11,3)$

$40 \quad 37,8(9,6)$

$1239,7(13,3)$

BCR $\| \mathrm{m}$. sph.

ani ext.

$1579,7(14,8)$

$3978,6(16,2)$

$1277,1(13,9)$

PEP

$1546,1(8,6)$

$40 \quad 44,0(6,0)$

$1341,5(2,7)$ *

PHEP

$766,6(9,0)$

$19 \quad 69,1(12,2)$

$7 \quad 79,3(35,1)$

${ }^{*} \mathrm{P}<0,05$ ( hypotoon - hypertoon )

Tabel 7.16

Latentietijden van reflexen en evoked potentials bij diabetici zonder en met pathologisch residu, zonder infravesicale obstructie (Gemiddelden en standaarddeviaties in ms)

$\begin{array}{ll}\text { pathologisch residu pathologisch residu } & \text { panwezig } \\ \text { niet aanwezig } & \text { aanwezig }\end{array}$

$N$ gemiddelde $N$ gemiddelde (SD)

(SD)

VAR m. sph. ani ext.

$56 \quad 72,9(13,1)$

$8 \quad 80,5(21,6)$

BCR I m. sph. ani ext.

$5636,5(7,9)$

$1048,7(17,1)$ *

BCR II m. sph. ani ext.

PEP

PHEP

$56 \quad 77,1(13,6)$

$987,8(22,5)$ *

$5743,4(6,2)$

$10 \quad 46,1(6,4)$

$2970,8(19,9)$

$367,3(5,0)$

${ }^{*} \mathrm{P}<0,05$ 
Latentietijden van reflexen en evoked potentials bij diabetici met een verlaagde, normale en verhoogde blaascapaciteit, zonder infravesicale obstructie

(Gemiddelden en standaarddeviaties in ms)

$\begin{array}{llll}>250 & 250-600 & >600 \\ N \begin{array}{l}\text { gemiddelde } \\ (\mathrm{SD})\end{array} & N \quad \begin{array}{l}\text { gemiddelde } \\ (\mathrm{SD})\end{array} & N \quad \begin{array}{l}\text { gemiddelde } \\ (\mathrm{SD})\end{array}\end{array}$

VAR m. sph.

$\begin{array}{lllllll}\text { ani ext. } & 10 & 74,8(16,2) & 40 & 72,6(12,8) & 15 & 76,0\end{array}(17,5)$

BCR I m. sph.

ani ext.

$10 \quad 39,7(15,3)$

$42 \quad 38,7(10,5)$

$1536,1(6,9)$

BCP II m. sph.

ani ext.

$1076,5(16,5)$

$4180,2(16,6)$

$1575,5(9,8)$

PEP

PHEP

$1141,5(3,9)$

$4243,9(6,5)$

$1546,1(6,7)$ *

$677,8(39,0)$

$2070,2(11,9)$

$7 \quad 66,3(8,8)$

${ }^{*} \mathrm{P}<0,05(<250->600 \mathrm{ml})$

Tabel 7.18

Latentietijden van reflexen en evoked potentials bij diabetici met een verlaagde, normale en te late eerste aandrang, zonder infravesicale obstructie

(Gemiddelden en standaarddeviaties in $\mathrm{ms}$ )

\begin{tabular}{|c|c|c|}
\hline$<50 \mathrm{ml}$ & $50-300 \mathrm{ml}$ & $>300 \mathrm{ml}$ \\
\hline $\begin{array}{l}\text { gemiddelde } \\
\text { (SD) }\end{array}$ & $\begin{array}{l}\text { glemiddelde } \\
(\mathrm{SD})\end{array}$ & $\begin{array}{l}\text { gemiddelde } \\
\text { (SD) }\end{array}$ \\
\hline
\end{tabular}

VAR m. sph.

ani ext.

1100,0

$46 \quad 73,2(14,4)$

$17 \quad 73,8(14,1)$

BCR I m. sph.

ani ext.

$258,0(29,7)$

$4737,9(9,9)$ *

$1737,5(8,2)$ *

BCR \| m. sph.

ani ext.

PEP

PHEP

$290,5(29,0)$

$46 \quad 78,7(16,7)$

$17 \quad 77,2(9,2)$

$243,0(1,4)$

$48 \quad 43,0(5,4)$

$1747,1(8,0)$ *

${ }^{*} \mathrm{P}<0,05$

$2472,1(21,2)$

$967,1(9,1)$

$\mathrm{BCR} \mathrm{I}(<50-50-300 \mathrm{ml})$ en $(<50->300 \mathrm{ml})$

PEP $\quad(50-300->300 \mathrm{ml})$ 
Latentietijolen van reflexen en evoked potentials bil diabetici met een verlaagde, normale en verhoogde maximale mictiedruk, zonder infravesicale obstructie (Gemiddelden en standaarddeviaties in $\mathrm{ms}$ )

$\begin{array}{cccc}<25 \mathrm{~cm} \text { water } & 25-80 \mathrm{~cm} \text { water } & >80 \mathrm{~cm} \text { water } \\ \mathrm{N} \begin{array}{l}\text { gemiddelde } \\ \text { (SD) }\end{array} & \mathrm{N} \quad \begin{array}{l}\text { gemiddelde } \\ \text { (SD) }\end{array} & \mathrm{N} & \text { gemiddelde } \\ \text { (SD) }\end{array}$

VAR m. sph. ani ext.

$2176,2(13,6)$

$3274,2(16,1)$

$362,0(8,0)$ *

BC:R $\mid \mathrm{m}$. sph.

ani ext.

$22 \quad 37,9(13,7) \quad 34 \quad 39,4(9,3) \quad 2 \quad 36,5(2,1)$

BCR $\| \mathrm{m}$. sph.

ani ext.

$2277,5(16,1)$

$3381,1(16,3)$

$269,5(3,5)$

PEP

$2242,6(6,6)$

$3445,1(6,6)$

$342,3(1,2)$

PHEP

$1174,2(24,5)$

$1473,8(15,8)$

$352,3(2,5)$ *

${ }^{*} \mathrm{P}<0,05$

VAR $(<25->80 \mathrm{~cm}$ water)

PHEP (25-80 - > $80 \mathrm{~cm}$ water ) 
Aantallen normale en verlengde latentietijden VAR en urogenitale klachten by diabetici

normaal verlengd totaal

\section{Continentie}

Intact

$26(59 \%)$

$18 \quad(41 \%)$

$2 .(40 \%)$

44

Stress incontinentie $3(60 \%)$

$14 \quad(50 \%)$

5

Urge incontinentie $14 \quad(50 \%)$

$14-(50 \%) \quad 28$

Mictiedrang

Intact

Geen

$39(61 \%)$

$25(39 \%) \quad 64$

$9(69 \%) \quad 13$

Passagegevoel

Intact

Geen

$39(58 \%)$

$28 \quad(42 \%)$

67

$6(60 \%)$

10

Blaasledigingsgevoel

Intact

Geen

Onbekend

$38 \quad(58 \%)$

$4 \quad(40 \%)$

$1 \quad(100 \%)$

Libido

Intact

Geen

Onbekend

27 ( 59\%)

$7 \quad(78 \%)$

$9(41 \%)$

Erectio

Intact

Geen

Onbekend

$\begin{aligned} 8 & (73 \%) \\ 13 & (62 \%) \\ 1 & (50 \%)\end{aligned}$

Ejaculatie

Intact

Geen

Onbekend

$$
\begin{array}{rr}
16 & (73 \%) \\
5 & (50 \%) \\
1 & (50 \%)
\end{array}
$$

Orgasme

Aanwezing

Geen

Onbekend
$25(62 \%)$

$8(57 \%)$

$10(44 \%)$
$28(42 \%)$

$6(60 \%)$

66

10

1

$19(41 \%) \quad 46$

$2(22 \%) \quad 9$

$13(59 \%) \quad 22$

$3(27 \%) \quad 11$

$8(38 \%) \quad 21$

$1(50 \%) \quad 2$

$6(27 \%) \quad 22$

$5(50 \%) \quad 10$

$1(50 \%) \quad 2$

$15(38 \%) \quad 40$

$6(43 \%) \quad 14$

$13(56 \%) \quad 23$ 
Aantallen normale en verlengde latentietijden BCR I en urogenitale klachten bif diabetici

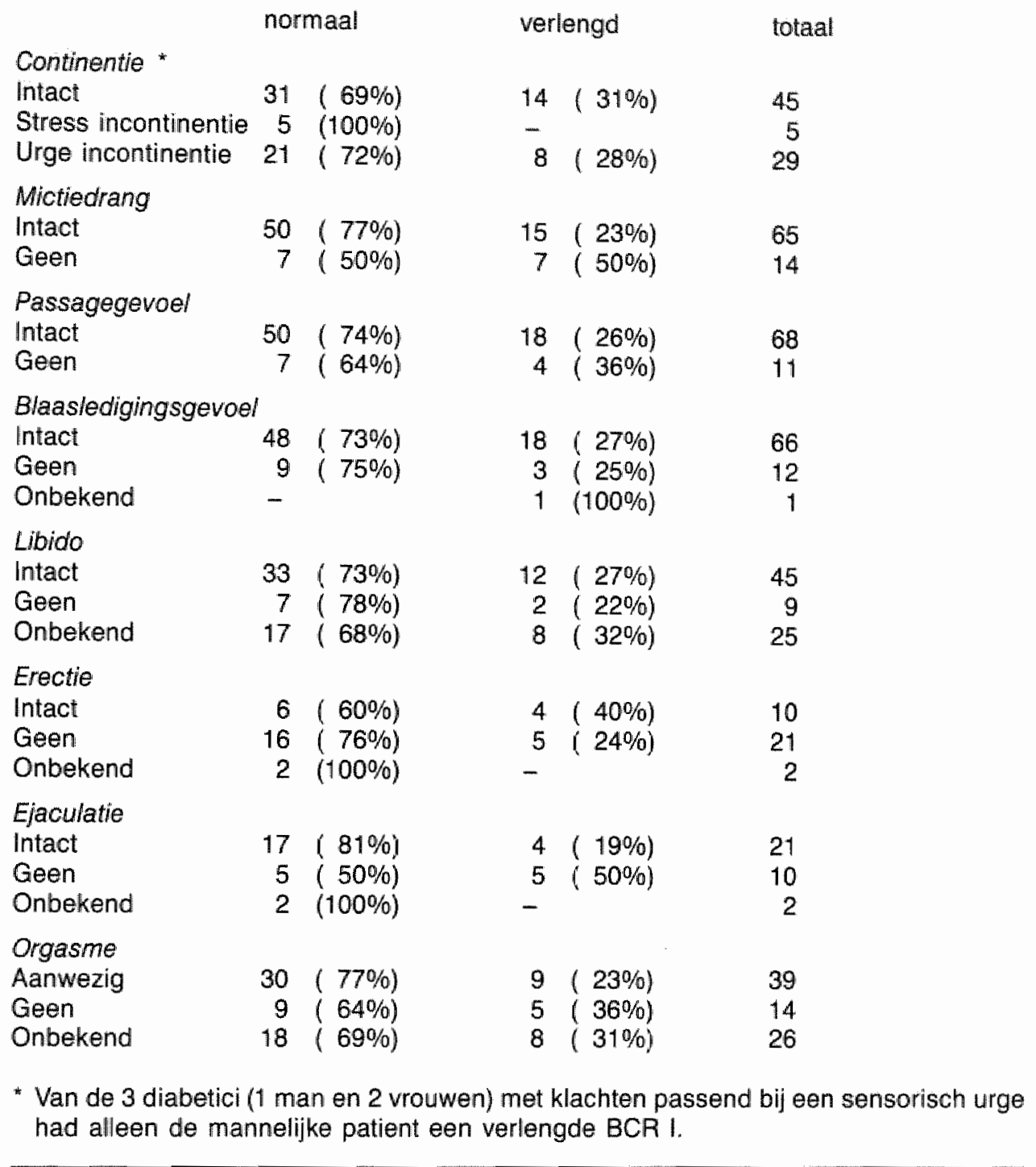


Aantallen nomale en verlengde latertietijden BCR N en urogenitale klachten bij diabetici

$$
\text { normaal }
$$

verlengd

totaal

Continentie

Aanwezig

$39(87 \%)$

$6(13 \%)$

45

Stress incontinentie $5(100 \%)$

Urge incontineritie $23 \quad(85 \%)$

$\begin{array}{llr}- & 5 \\ 4 & (15 \%) & 27\end{array}$

Mictiedrang

Intact

$55(86 \%)$

Geen

$12(92 \%)$

$9(14 \%)$

64

$1(8 \%)$

13

Passagegevoel

Intact

$59(88 \%)$

$8 \quad(12 \%)$

67

Geen

$8(80 \%)$

$2(20 \%)$

10

Blaasledigingsgevoel

Intact

Geen

$$
57(88 \%)
$$

$10 \quad(91 \%)$

$8(12 \%)$

65

1 (9\%)

11

Libido

Intact

Geen

Onbekend

$39 \quad(89 \%)$

8 ( $89 \%)$

20 ( $83 \%)$

$5 \quad(11 \%)$

$1(11 \%)$

$4(17 \%)$

44

9

24

Erectio

Intact

Geen

Onbekend

$8 \quad(89 \%)$

$18 \quad(86 \%)$

$2(100 \%)$

$1 \quad(11 \%)$

9

$3(14 \%)$

21

2

Ejaculatie

Intact

Geen

Onbekend

$18(90 \%)$

$8 \quad(80 \%)$

$2(100 \%)$

$2(10 \%)$

20

2 (20\%)

10

Orgasme

Aanwezig

Geen

Onbekend
$34(90 \%)$

12 ( $86 \%)$

$21(84 \%)$
$4 \quad(10 \%)$

$2(14 \%)$

$4(16 \%)$
38

14

25 
Aantalien normale en verlengde latentietijden PEP en urogenitale klachten bij mannelike en vrouwelike diabetici

norma al

mannen vrouwen totaal mannen vrouwen totaal

Continentie *

Intact

Stress incontinentie -

$21(57 \%) 16(43 \%) \quad 37$

$4(100 \%) \quad 4$

Urge incontinentie

$5(23 \%) 17(77 \%) \quad 22$

Mictiedrang

Intact

Geen

$25(46 \%) 29(54 \%) \quad 54$

$1(11 \%) 8(89 \%) \quad 9$

Passagegevoel

Intact

Geen
$5(62 \%) 3(38 \%) \quad 8$

- $\quad 1(100 \%) 1$

$2(29 \%) 5(71 \%) 7$

$5(45 \%) 6(55 \%) 11$

$2(40 \%) 3(60 \%) 5$

Blaasledigingsgevoel

Intact

Geen

Onbekend

Libido

Intact

Geen

Onbekend

Erectie

Intact

Geen

Onbekend

Ejaculatie

Intact

Geen

Onbekend

Orgasme

Aanwezig

Geen

Onbekend

$\begin{array}{rrrrrr}23(77 \%) 30(23 \%) & 53 & 7(54 \%) & 6(46 \%) & 13 \\ 3(33 \%) & 6(67 \%) & 9 & - & 3(100 \%) & 3 \\ - & 1(100 \%) & 1 & - & - & -\end{array}$

$\begin{array}{crrrr}22(55 \%) 18(45 \%) & 40 & 5(100 \%) & - & 5 \\ 3(75 \%) 4(25 \%) & 7 & 1(50 \%) & 1(50 \%) & 2 \\ 1(7 \%) 15(93 \%) & 16 & 1(11 \%) 8(89 \%) & 9\end{array}$

$83(100 \%)-3$

$173(100 \%)-3$

$11(100 \%)-1$

$1(100 \%)-$

19

$3(100 \%)-$

3

$19(100 \%)-$

$6(100 \%)-$

$1(100 \%)-$

$63(100 \%)-$

$1(100 \%)-$

3

1

$\begin{array}{lll}5(100 \%) & - & 5 \\ 1(50 \%) & 1(50 \%) & 2 \\ 1(11 \%) & 8(89 \%) & 9\end{array}$

* Van de 3 diabetici ( 1 man en 2 vrouwen) met klachten passend bij een sensorisch urge, had alleen de mannelijke patient een verlengde latentietijd van de PEP. 
Aantalien normale en verlengde latentietijen PEP en urogenitale klachten bij diabetici

$$
\text { normaal verlengd totaal }
$$

Continentie

$\begin{array}{lrrrrr}\text { Intact } & 37 & (82 \%) & 8 & (18 \%) & 45 \\ \text { Stress incontinentie } & 4 & (80 \%) & 1 & (20 \%) & 5 \\ \text { Urge incontinentie } & 22 & (76 \%) & 7 & (24 \%) & 29 \\ \text { Mictiedrang } & & & & & \\ \text { Intact } & 54 & (83 \%) & 11 & (17 \%) & 65 \\ \text { Geen } & 9 & (64 \%) & 5 & (36 \%) & 14\end{array}$

Passagegevoel

Intact

Geen
$54 \quad(79 \%)$

Blaasledigingsgevoel

Intact

Geen

Onbekend

Libido

Intact

Geen

Onbekend

$53(80 \%)$

$9(75 \%)$

$1(100 \%)$

$40 \quad(89 \%)$

$7 \quad(78 \%)$

16. $(64 \%)$

Erectie

Intact

Geen

Onbekend

Ejaculatie

Intact

Geen

Onbekend

Orgasme

Aanwezig

Geen

Onbekend

$$
\begin{array}{rr}
8 & (73 \%) \\
17 & (85 \%) \\
1 & (50 \%)
\end{array}
$$

$19 \quad(86 \%)$

$6(67 \%)$

1 (50\%)

$35(88 \%)$

$11(85 \%)$

$17(65 \%)$
$14(21 \%)$

$2(18 \%)$

68

11

$13 \quad(20 \%)$

$3(25 \%)$

66

12

- 1

$5(11 \%) \quad 45$

$2(22 \%) \quad 9$

9 $(36 \%) \quad 25$

$3 \quad(27 \%) \quad 11$

$3(15 \%) \quad 20$

$1(50 \%) \quad 2$

$3(14 \%) \quad 22$

$3(33 \%) \quad 9$

$1(50 \%) 2$

$5(12 \%) \quad 40$

$2(15 \%) \quad 13$

$9(35 \%) \quad 26$ 
Aantallen normale en veriengde latentietijden PHEP en urogenitale klachten bij diabetici

normaal

Continentie

intact $21 \quad(84 \%)$

Stress incontinentie $4(100 \%)$

Urge incontinentie $7(70 \%)$

Mictiedrang

Intact

Geen

$29(83 \%)$

$3(75 \%)$

Intact

Geen
Passagegevoel

verlengd

Blaasledigingsgevoel

Intact

Geen

Onbekend

Libido

Intact

Geen

Onbekend

$$
\begin{array}{rr}
24 & (77 \%) \\
8 & (100 \%)
\end{array}
$$

$2(67 \%)$

$10(77 \%)$

Erectie

Intact

Geen

Onbekend

$$
\begin{array}{rr}
5 & (100 \%) \\
10 & (83 \%) \\
1 & (50 \%)
\end{array}
$$

Ejaculatie

Intact

Geen

Onbekend

Orgasme

Aanwezig

Geen

Onbekend
$12(86 \%)$

$3(100 \%)$

$1(50 \%)$

$19(86 \%)$

$3(75 \%)$

$10(77 \%)$
$4(16 \%)$

- 4

$3(30 \%) \quad 10$

$6(17 \%) \quad 35$

$1(25 \%) 4$

$6(18 \%) \quad 34$

$1(20 \%) \quad 5$

$7 \quad(23 \%)$

31

-

$-$

$3(13 \%)$

$1(33 \%)$

$3(23 \%)$

23

totaal

25

4

5

4

34

5

8

3
13

5

$2(17 \%) \quad 12$

$1(50 \%) \quad 2$

$2(14 \%) \quad 14$

- 3

$1(50 \%) \quad 2$

$3(14 \%) \quad 22$

$1(25 \%) \quad 4$

$3(23 \%) \quad 13$ 
Aantallen nommale en verlengde latentietijen VAR en urologische parameters bij diabetici

Residu

Geen residu $\quad 34(61 \%)$

Pathologisch residu $3(38 \%)$

normaal

veriengd

totaal

Blaascapaciteit

$<250 \mathrm{ml}$

$6(60 \%)$

$250-600 \mathrm{ml}$

$>600 \mathrm{ml}$

$24 \quad(60 \%)$

$8(53 \%)$

$22(39 \%)$
5

56

Eerste aandrang

$<50 \mathrm{ml}$

$50-300 \mathrm{ml}$

$>300 \mathrm{ml}$

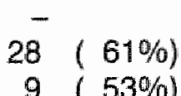

$4(40 \%)$

$16(40 \%)$

7 (47\%)

10

40

Detrusorgedrag

Hypotoon

Normaal

Hypertoon

$9(53 \%)$

$\begin{array}{rrr}1 & (100 \%) & 1 \\ 18 & (39 \%) & 46\end{array}$

8. $(47 \%) \quad 17$

Maximale mictiedruk

$<25$ cm water 9 (43\%)

$25.80 \mathrm{~cm}$ water $20 \quad(62 \%)$

$>80 \mathrm{~cm}$ water

$\begin{aligned} 7 & (47 \%) \\ 24 & (63 \%) \\ 7 & (58 \%)\end{aligned}$

$8(53 \%)$

15

$14(37 \%) \quad 38$

$5(42 \%) \quad 12$

$3(100 \%)$

$12(57 \%)$

21

$12(38 \%)$

32

3

Tabel 7.27

Aantallen normale en verlengde latentietijden BCA I en urologische parameters bij diabetici

normaal

verlengd

totaal

Residu

Geen residu

$44(79 \%)$

Pathologisch residu $5 \quad(50 \%)$

$12(21 \%)$

56

$5(50 \%)$

10

Blaascapaciteit

$<250 \mathrm{ml}$

$250-600 \mathrm{ml}$

$8(80 \%)$

$2(20 \%) \quad 10$

$>600 \mathrm{ml}$

$30(71 \%)$

$12(29 \%)$

42

$3(20 \%)$

15

Eerste aandrang

$<50 \mathrm{ml}$

$50-300 \mathrm{ml}$

$1(50 \%)$

$1(50 \%)$

2

$12(26 \%)$

47

$>300 \mathrm{ml}$

$14(82 \%)$

$3(18 \%)$

17

Detrusorgedrag

Hypotoon

Normaal

Hypertoon
$3 \quad(20 \%)$

$12(30 \%)$

$2(17 \%)$

15

40

12

Maximale mictiedruk

$<25 \mathrm{~cm}$ water 18

$25-80 \mathrm{~cm}$ watter

$18(82 \%)$

$22(65 \%)$

$>80 \mathrm{~cm}$ water

$2(100 \%)$

$4(18 \%)$

22

$12(35 \%)$

34

\begin{tabular}{l} 
- 2 \\
\hline
\end{tabular} 
Aantallen normale en veriengde latentietjiden BCA II en urologisohe parameters bif diabetici

normaal

Residu

Geen residu $51(91 \%)$

Pathologisch residu 6 (67\%)

Blaascapaciteint

$<250 \mathrm{ml}$

$250-600 \mathrm{ml}$

$>600 \mathrm{ml}$

$\begin{aligned} 9 & (90 \%) \\ 35 & (85 \%) \\ 14 & (93 \%)\end{aligned}$

$<50 \mathrm{ml}$

$50-300 \mathrm{ml}$

$>300 \mathrm{ml}$

$1 \quad(50 \%)$

$40 \quad(87 \%)$

$16(94 \%)$

Detrusorgedrag

Hypotoon

Normaal

$14(93 \%)$

$33(85 \%)$

$11(92 \%)$

Hypertoon
Eerste aandrang

verlengd

totaal

$5 \quad(9 \%)$

$3(33 \%)$

56

9

$1(10 \%)$

$6(15 \%)$

$1(7 \%)$

10

41

15

$1(50 \%) \quad 2$

$6(13 \%) \quad 46$

$1(6 \%) \quad 17$

Maximale mictiedruk

$<25 \mathrm{~cm}$ water
$25-80 \mathrm{~cm}$ water
$>80 \mathrm{~cm}$ water

$20(91 \%)$

$27(82 \%)$

$2(100 \%)$
$1(7 \%) \quad 15$

$6(15 \%) \quad 39$
$1(8 \%) \quad 12$

$>80 \mathrm{~cm}$ water

$2(9 \%)$

22

$6(18 \%) \quad 33$

- 2 
Aantallen normale en verlengde latentietijden PEP en urologische parameters bij mannelijke en vrouwelijke diabetici

$$
\begin{aligned}
& \text { morm a a } \\
& \text { mannen vrouwen totaal mannen vrouwen totaal }
\end{aligned}
$$

Residu

$\begin{array}{lrlllll}\text { Geen residu } & 22(44 \%) & 28(56 \%) & 50 & 4(36 \%) & 7(64 \%) & 11 \\ \text { Pathologisch residu } & 3(27 \%) & 8(73 \%) & 11 & 2(50 \%) & 2(50 \%) & 4\end{array}$

Pathologisch residu $3(27 \%) \quad 8(73 \%) \quad 11 \quad 2(50 \%) \quad 2(50 \%) 4$

\section{Blaascapaciteit}

$\begin{array}{lrrrrrr}<250 \mathrm{ml} & 4(36 \%) & 7(64 \%) & 11 & - & 2(100 \%) & 1 \\ 250.600 \mathrm{ml} & 14(37 \%) & 24(63 \%) & 38 & 4(40 \%) & 6(60 \%) & 10 \\ >600 \mathrm{ml} & 8(57 \%) & 6(43 \%) & 14 & 3(60 \%) & 2(40 \%) & 5\end{array}$

Eerste aandrang

$<50 \mathrm{ml}$

$50 \cdot 300 \mathrm{ml}$

$>300 \mathrm{ml}$

$$
\begin{array}{rrrrrr}
2(100 \%) & 2 & - & - & - \\
21(45 \%) 26(55 \%) & 47 & 3(33 \%) & 6(67 \%) & 9 \\
5(38 \%) & 8(62 \%) & 13 & 4(57 \%) & 3(43 \%) & 7
\end{array}
$$

\begin{tabular}{|c|c|c|c|c|}
\hline Iypotoon & $4(29 \%) 10(71 \%)$ & 14 & $3(60 \%)$ & $2(40 \%)$ \\
\hline al & $16(46 \%) 19(54 \%)$ & 35 & $4(40 \%)$ & $6(60 \%)$ \\
\hline Hypertoon & $6(43 \%) 8(57 \%)$ & 14 & & $1(100 \%)$ \\
\hline
\end{tabular}

Detrusorgedrag

Maximale mictiedruk

$\begin{array}{lccccc}<25 \mathrm{~cm} \text { water } & 4(20 \%) 16(80 \%) & 20 & 2(40 \%) & 3(60 \%) & 5 \\ 25-80 \mathrm{~cm} \text { water } & 16(53 \%) 14(47 \%) & 30 & 4(44 \%) & 5(56 \%) & 9 \\ >80 \mathrm{~cm} \text { water } & 4(100 \%)- & 4 & - & - & -\end{array}$


Aantallen normale en verlengde latentietijden PEP en urologische parameters bij diabetici

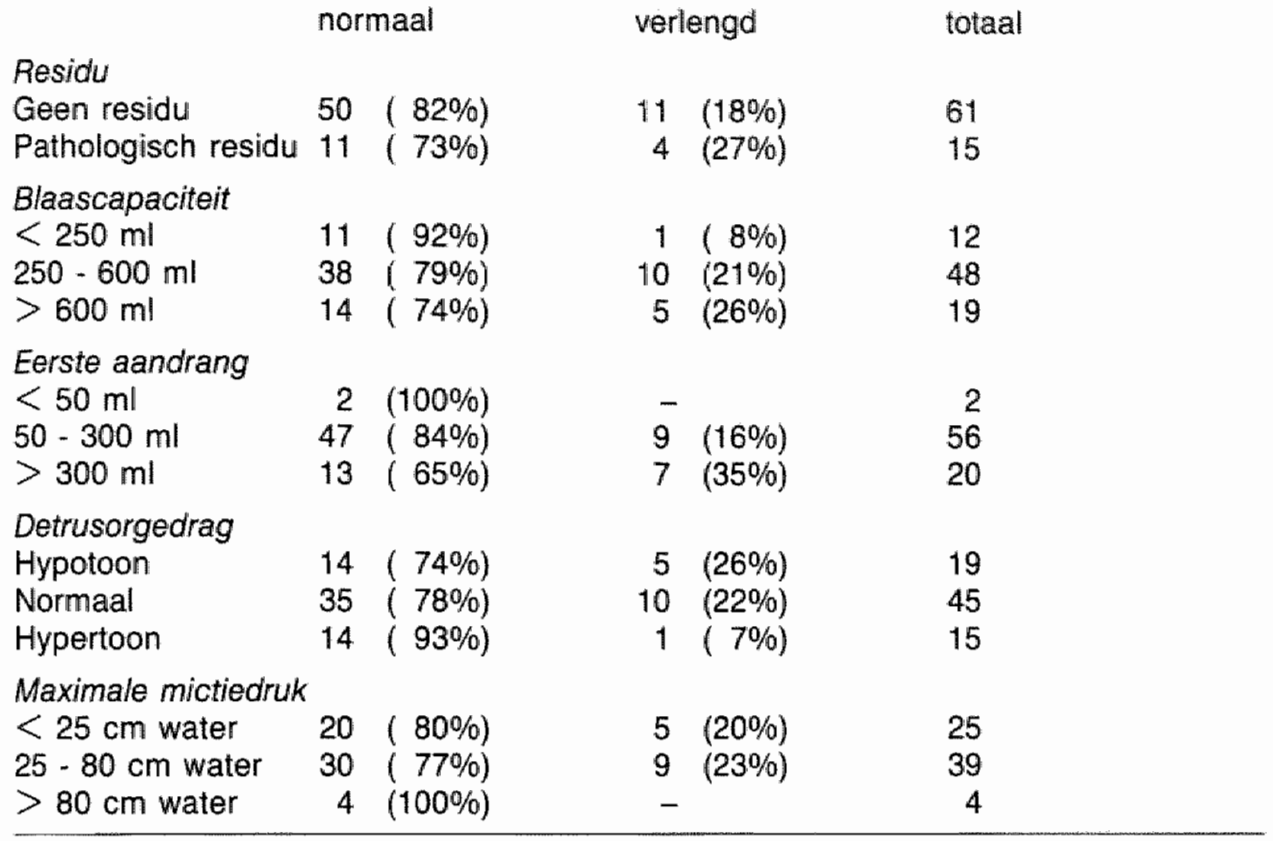

Tabel 7.31

Aantallen normale en verlengde latentietijden PHEP en urologische parameters bij diabetici

normaal verlengd totaal

Residu

\begin{tabular}{|c|c|c|c|c|c|}
\hline $\begin{array}{l}\text { Geen residu } \\
\text { Pathologisch residu }\end{array}$ & $\begin{array}{r}24 \\
3\end{array}$ & $\begin{array}{l}(83 \%) \\
(100 \%)\end{array}$ & $\begin{array}{l}5 \\
-\end{array}$ & $(17 \%)$ & $\begin{array}{r}29 \\
3\end{array}$ \\
\hline $\begin{array}{l}\text { Blaascapaciteit } \\
<250 \mathrm{ml} \\
250-600 \mathrm{ml} \\
>600 \mathrm{ml}\end{array}$ & $\begin{array}{r}4 \\
17 \\
7\end{array}$ & $\begin{array}{l}(670 \%) \\
(85 \%) \\
(100 \%)\end{array}$ & $\begin{array}{l}2 \\
3 \\
-\end{array}$ & $\begin{array}{l}(33 \%) \\
(15 \%)\end{array}$ & $\begin{array}{r}6 \\
20 \\
7\end{array}$ \\
\hline $\begin{array}{l}\text { Eerste aandrang } \\
<50 \mathrm{ml} \\
50-300 \mathrm{ml} \\
>300 \mathrm{ml}\end{array}$ & $\begin{array}{r}- \\
19 \\
9\end{array}$ & $\begin{array}{c}- \\
(79 \%) \\
(100 \%)\end{array}$ & 5 & $(21 \%)$ & $\begin{array}{r}24 \\
9\end{array}$ \\
\hline $\begin{array}{l}\text { Detrusorgedrag } \\
\text { Hypotoon } \\
\text { Normaal } \\
\text { Hypertoon }\end{array}$ & $\begin{array}{r}7 \\
17 \\
4\end{array}$ & $\begin{array}{l}(100 \%) \\
(90 \%) \\
(57 \%)\end{array}$ & $\begin{array}{l}- \\
2 \\
3\end{array}$ & $\begin{array}{l}(10 \%) \\
(43 \%)\end{array}$ & $\begin{array}{r}7 \\
19 \\
7\end{array}$ \\
\hline $\begin{array}{l}\text { Maximale mictiedruk } \\
<25 \mathrm{~cm} \text { water } \\
25-80 \mathrm{~cm} \text { water } \\
>80 \mathrm{~cm} \text { water }\end{array}$ & $\begin{array}{r}10 \\
10 \\
3\end{array}$ & $\begin{array}{l}(91 \%) \\
(710 \%) \\
(100 \%)\end{array}$ & $\begin{array}{l}1 \\
4 \\
-\end{array}$ & $\begin{array}{l}(9 \%) \\
(29 \%)\end{array}$ & $\begin{array}{r}11 \\
14 \\
3\end{array}$ \\
\hline
\end{tabular}


APPENDIX 7.2.4. 


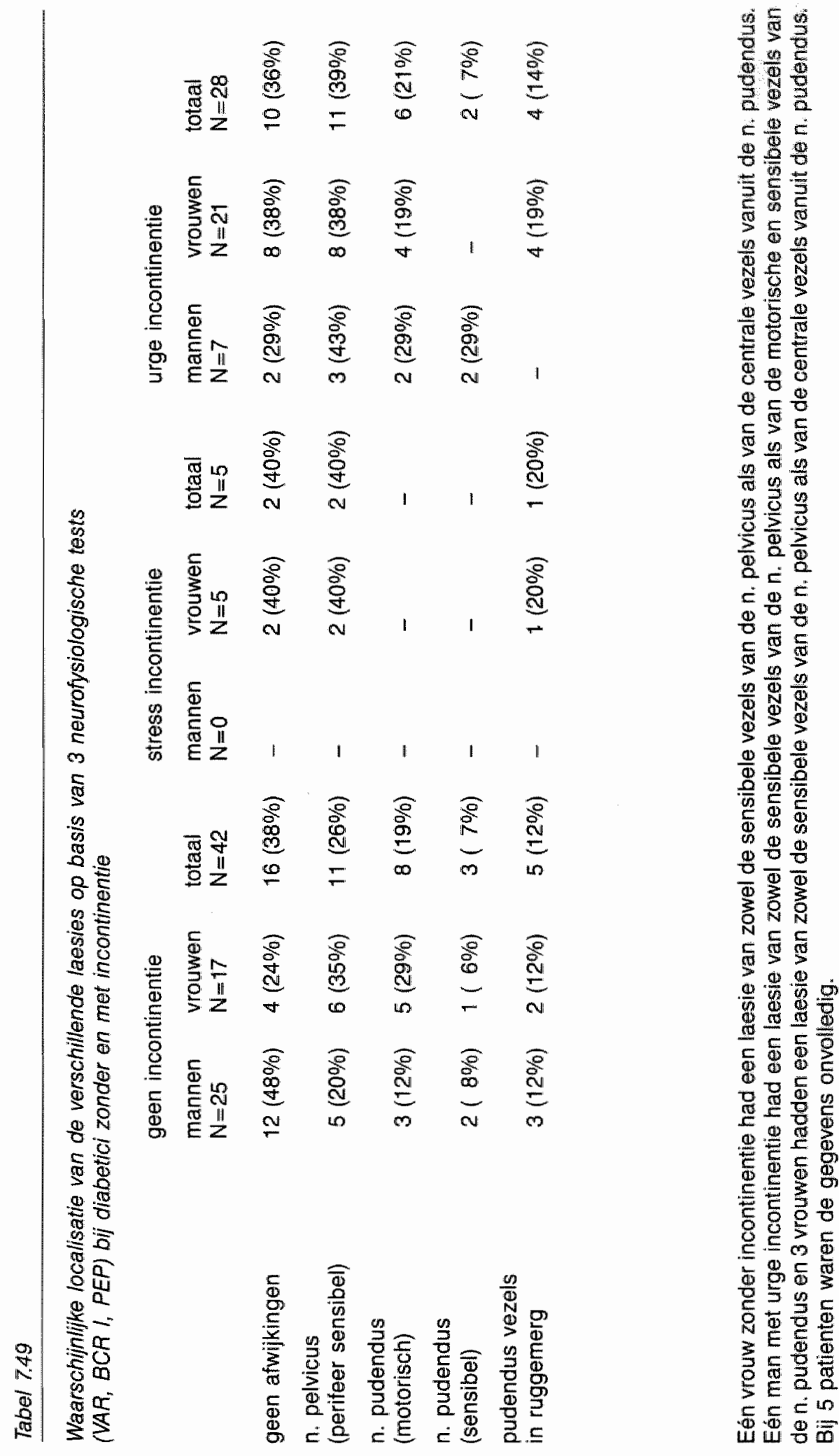


Waarschijnlike localisatie van de verschillende laesies op basis van 3 neurofysiologische tests (VAR, BCR I, PEP) bij diabetici met intacte en met ontbrekende mictiedrang

\begin{tabular}{|c|c|c|c|c|c|c|}
\hline & intacte $\mathrm{mi}$ & tledrang & & ontbreke & de mictiec & ang \\
\hline & $\begin{array}{l}\text { mannen } \\
\mathbb{N}=29\end{array}$ & $\begin{array}{l}\text { vrouwen } \\
N=33\end{array}$ & $\begin{array}{l}\text { totaal } \\
N=62\end{array}$ & $\begin{array}{l}\text { mannen } \\
N=3\end{array}$ & $\begin{array}{l}\text { vrouwen } \\
N=10\end{array}$ & $\begin{array}{l}\text { totaal } \\
N=13\end{array}$ \\
\hline geen afwikingen & $14(48 \%)$ & $12(36 \%)$ & $26(42 \%)$ & - & $2(20 \%)$ & $2(15 \%)$ \\
\hline $\begin{array}{l}\text { n. pelvicus } \\
\text { (perifeer sensibel) }\end{array}$ & $7(24 \%)$ & $11(33 \%)$ & $18(29 \%)$ & $1(33 \%)$ & $5(50 \%)$ & $6(46 \%)$ \\
\hline $\begin{array}{l}\text { n. pudendus } \\
\text { (motorisch) }\end{array}$ & $3(10 \%)$ & $7(21 \%)$ & $10(16 \%)$ & $2(67 \%)$ & $2(20 \%)$ & $4(31 \%)$ \\
\hline $\begin{array}{l}\text { n. pudendus } \\
\text { (sensibel) }\end{array}$ & $2(7 \%)$ & - & $2(3 \%)$ & $2(67 \%)$ & $1(10 \%)$ & $3(23 \%)$ \\
\hline $\begin{array}{l}\text { udendus vezels } \\
\text { ruggemerg }\end{array}$ & $3(10 \%)$ & $6(18 \%)$ & $9(15 \%)$ & - & $1(10 \%)$ & $\|(8 \%)$ \\
\hline
\end{tabular}

Van de patienten met intacte mictiedrang hadden 3 vrouwen een laesie van zowel de sensibele vezels van de n. pelvicus als van de centrale vezels vanuit de $n$. pudendus.

Eèn man met een ontbrekende mictiedrang had een laesie van zowel de sensibele vezels van de $n$. pelvicus als van de sensibele en motorische vezels van de $n$. pudendus. Eên vrouw had een laesie van zowel de sensibele vezels van de $n$. pelvicus als van de centrale vezels vanuit de $n$. pudendus. Bij 5 patienten waren de gegevens onvolledig.

Tabel 7.51

Waarschijnlijke localisatie van de verschillende laesies op basis van 3 neurofysiologische tests (VAR, BCR I, PEP) bij diabetici met intact en met afwezig passagegevoel

\begin{tabular}{llllll} 
intact passagegevoel & \multicolumn{4}{l}{ afwezig passagegevoel } \\
$\begin{array}{l}\text { mannen } \\
N=30\end{array}$ & $\begin{array}{l}\text { vrouwen } \\
N=35\end{array}$ & totaal & mannen & vrouwen & totaal \\
$13(43 \%)$ & $12(34 \%)$ & $25(38 \%)$ & $1(50 \%)$ & $2(25 \%)$ & $3(30 \%)$ \\
$7(23 \%)$ & $12(34 \%)$ & $19(29 \%)$ & $1(50 \%)$ & $4(50 \%)$ & $5(50 \%)$ \\
$4(13 \%)$ & $7(20 \%)$ & $11(17 \%)$ & $1(50 \%)$ & $2(25 \%)$ & $3(30 \%)$ \\
$3(10 \%)$ & $1(3 \%)$ & $4(6 \%)$ & $1(50 \%)$ & - & $1(10 \%)$ \\
$3(10 \%)$ & $7(20 \%)$ & $10(15 \%)$ & - & - & -
\end{tabular}

Van de patienten met intact passagegevoel hadden 4 vrouwen een laesie van zowel de sensibele vezels van de $n$. pelvicus als van de centrale vezels vanuit de $n$. pudendus. Van de patienten met een afwezig passagegevoel had één man een laesie van zowel de sensibele vezels van de $n$. pelvicus als van de sensibele en motorische vezels van de $\mathrm{n}$. pudendus. Bij 5 patienten waren de gegevens onvolledig. 
Waarschinilike localisatie van de verschillende laesies op basis van 3 neurolysiologische tests (NAR, BCR I, PEP) bij diabetici met intact en mot afwezig blaasledigingsgevoel

\begin{tabular}{llllll}
\multicolumn{2}{l}{$\begin{array}{l}\text { intact blaasledigingsgevoel } \\
\text { mannen }\end{array}$} & vrouwen & totaal & mannen & blaasledigingsgevoel \\
$\mathrm{N}=29$ & $\mathrm{~N}=35$ & $\mathrm{~N}=64$ & $\mathrm{~N}=3$ & $\mathrm{~N}=7$ & $\mathrm{~N}=10$ \\
$12(41 \%)$ & $13(37 \%)$ & $25(39 \%)$ & $2(67 \%)$ & $1(14 \%)$ & $3(30 \%)$ \\
$8(28 \%)$ & $11(31 \%)$ & $19(30 \%)$ & - & $5(71 \%)$ & $5(50 \%)$ \\
$4(14 \%)$ & $8(23 \%)$ & $12(19 \%)$ & $1(33 \%)$ & - & $1(10 \%)$ \\
$4(14 \%)$ & $1(3 \%)$ & $5(8 \%)$ & - & - & - \\
$3(10 \%)$ & $5(14 \%)$ & $8(12 \%)$ & - & $2(29 \%)$ & $2(20 \%)$
\end{tabular}

Van de patienten met een intact blaasledigingsgevoel had én man een laesie van zowel de sensibele vezels van de $n$. pelvicus als van de sensibele en motorische vezels van de $n$. pudendus. 3 vrouwen hadden een laesie van zowel de centrale vezels vanuit de n. pudendus als van de sensibele vezels van de $\mathrm{n}$. pelvicus.

Van de patienten met een afwezig blaasledigingsgevoel had één vrouw een laesie van zowel de centrale vezels vanuit de $n$. pudendus als van de sensibele vezels van de $n$. pelvicus. Bij 6 patienten waren de gegevens onvolledig.

Tabel 7.53

Waarschijnlijke localisatie van de verschillende laesies op basis van 3 neurofysiologische tests (NAR, BCR I, PEP) bij diabetici met intact en met ontbrekend libido

\begin{tabular}{|c|c|c|c|c|c|}
\hline \multicolumn{3}{|c|}{ intact libido } & \multicolumn{3}{|c|}{ ontbrekend libido } \\
\hline $\begin{array}{l}\text { mannen } \\
N=26\end{array}$ & $\begin{array}{l}\text { vrouwen } \\
N=18\end{array}$ & $\begin{array}{l}\text { totaal } \\
N=44\end{array}$ & $\begin{array}{l}\text { mannen } \\
\mathrm{N}=4\end{array}$ & $\begin{array}{l}\text { vrouwen } \\
N=5\end{array}$ & $\begin{array}{l}\text { totaal } \\
N=9\end{array}$ \\
\hline $12(46 \%)$ & $7(39 \%)$ & $19(43 \%)$ & $2(50 \%)$ & $3(60 \%)$ & $5(56 \%)$ \\
\hline $7(27 \%)$ & $7(39 \%)$ & $14(32 \%$ & - & - & - \\
\hline $4(15 \%)$ & $4(22 \%)$ & $8(18 \%)$ & $1(25 \%)$ & $1(20 \%)$ & $2(22 \%)$ \\
\hline $4(15 \%)$ & - & $4(9 \%)$ & - & - & - \\
\hline $1(4 \%)$ & - & $1(2 \%)$ & $1(25 \%)$ & $1(20 \%)$ & $2(22 \%)$ \\
\hline
\end{tabular}

Van de patienten met een intact libido had één man een laesie van zowel de sensibele vezels van de $n$. pelvicus als van de motorische en sensibele vezels van de $n$. pudendus. Bij 5 patienten waren de gegevens onvolledig en 2 mannen en 20 vrouwen konden de vraag niet beantwoorden. 
Waarschinilike localisatie wan de verschillende laesies op basis van 3 neurofysiologische tests (VAR, BCR I, PEP) bil mannelike diabetici met intacte en met afwezige erectie

$\begin{array}{lll} & \begin{array}{l}\text { intacte erectie } \\ N=10\end{array} & \begin{array}{l}\text { afwezige erectie } \\ N=20\end{array} \\ \text { geen afwijkinglen } & 5(50 \%) & 9(45 \%) \\ \text { n. pelvicus (perifeer sensibel) } & 2(20 \%) & 5(25 \%) \\ \text { n. pudendus (motorisch) } & 2(20 \%) & 3(15 \%) \\ \text { n. pudendus (sensibel) } & 3(30 \%) & 1(5 \%) \\ \text { pudendus vezels in ruggemerg } & - & 2(10 \%)\end{array}$

Van de patienten met een intacte erectie had één man een laesie van zowel de sensibele vezels van de $n$. pelvicus als van de sensibele en motorische vezels van de $n$. pudendus. 2 oudere mannen konden de vraag niet beantwoorden. Bij 2 mannen waren de gegevens onvolledig.

\section{Tabel 7.55}

Waarschijhlijke localisatie van de verschillende laesies op basis van 3 neurofysiologische tests (VAR, BCR I, PEP) bij mannelijke diabetici met intacte en met afwezige ejaculatie

geen afwijkingen

n. pelvicus (perifeer sensibel)

n. pudendus (motorisch)

n. pudendus (sensibel)

pudendus vezels in ruggemerg

$$
\begin{array}{ll}
\text { intacte ejaculatie } & \text { afwezigle ejaculatie } \\
N=21 & N=9
\end{array}
$$$$
13(62 \%)
$$$$
5(24 \%)
$$$$
2(10 \%)
$$$$
3(14 \%)
$$$$
1(11 \%)
$$$$
2(22 \%)
$$$$
3(33 \%)
$$$$
1(11 \%)
$$$$
2(22 \%)
$$

Van de patienten met een intacte ejaculatie had één man een laesie van zowel de sensibele vezells van de $n$. pelvicus als van de sensibele en motorische vezels van de $n$. pudendus. 2 mannen konden de vraag niet beantwoorden. Bij 2 mannen waren de gegevens onvolledig. 
Waarschijnlijke localisatie van de verschillende laesies op basis van 3 neurofysiologische tests (NAR, BCR I, PEP) bij diabetici met aamwezig en met ontbrekend orgasme

\begin{tabular}{llllllll} 
& \multicolumn{3}{c}{ aanwezig orgasme } & \multicolumn{3}{c}{ ontbrekend orgasme } \\
& $\begin{array}{l}\text { mannen } \\
N=24\end{array}$ & $\begin{array}{l}\text { vrouwen } \\
N=15\end{array}$ & $\begin{array}{l}\text { totaal } \\
N=39\end{array}$ & $\begin{array}{l}\text { mannen } \\
N=6\end{array}$ & $\begin{array}{l}\text { vrouwen } \\
N=7\end{array}$ & totaal \\
& $13(54 \%)$ & $5(33 \%)$ & $18(46 \%)$ & $1(17 \%)$ & $4(57 \%)$ & $5(38 \%)$ \\
geen afwijkingen & $\begin{array}{l}\text { n. pelvicus } \\
\text { (perifeer sensibel) }\end{array}$ & $6(25 \%)$ & $6(40 \%)$ & $12(31 \%)$ & $1(17 \%)$ & $1(14 \%)$ & $2(15 \%)$ \\
$\begin{array}{l}\text { n. pudendus } \\
\text { (motorisch) }\end{array}$ & $2(8 \%)$ & $4(27 \%)$ & $6(15 \%)$ & $3(50 \%)$ & $1(14 \%)$ & $4(31 \%)$ \\
$\begin{array}{l}\text { n. pudendus } \\
\text { (sensibel) }\end{array}$ & $4(17 \%)$ & - & $4(10 \%)$ & - & - & - \\
$\begin{array}{l}\text { pudendus vezels } \\
\text { in ruggemerg }\end{array}$ & $1(4 \%)$ & - & $1(3 \%)$ & $1(17 \%)$ & $1(14 \%)$ & $2(15 \%)$
\end{tabular}

Eén man met een aanwezig orgasme had een laesie van zowel de sensibele vezels van de $n$. pelvicus als van de sensibele en motorische vezels van de $n$. pudendus. Bij 2 patienten waren de gegevens onvolledig. 3 mannen en 23 vrouwen konden de vraag niet beantwoorden. 



\section{CURRICULUM VITAE}

De schrijver werd op 28 maart 1943 geboren te Heerlen.

Hij behaalde het diploma HBS-B aan het St. Bernardinus College te Heerlen in 1962 en studeerde geneeskunde aan de Gemeentelijke Universiteit te Amsterdam. Deze studie werd voortgezet aan de Erasmus Universiteit te Rotterdam en in 1970 afgesloten met het artsexamen.

In hetzelfde jaar begon hij zijn opleiding tot zenuwarts in het De Wever Ziekenhuis te Heerlen (opleider neurologie: Dr. J.G.Y. de Jong en opleider klinische-neurofysiologie: Prof. Dr. J.M.F. Moll).

De opleiding werd in 1976 afgesloten op de afdeling psychiatrie van het Radboud Ziekenhuis te Nijmegen (hoofd: Prof. Dr. S.Y. Nijdam).

Nadien was hij gedurende 1 jaar chef de clinique op de afdeling klinische-neurofysiologie van het Maaslandziekenhuis te Sittard.

Vanaf 1977 is hij als neuroloog werkzaam in het Maaslandziekenhuis te Sittard/Geleen. 
Druk: Huntjens bv - Stein 